

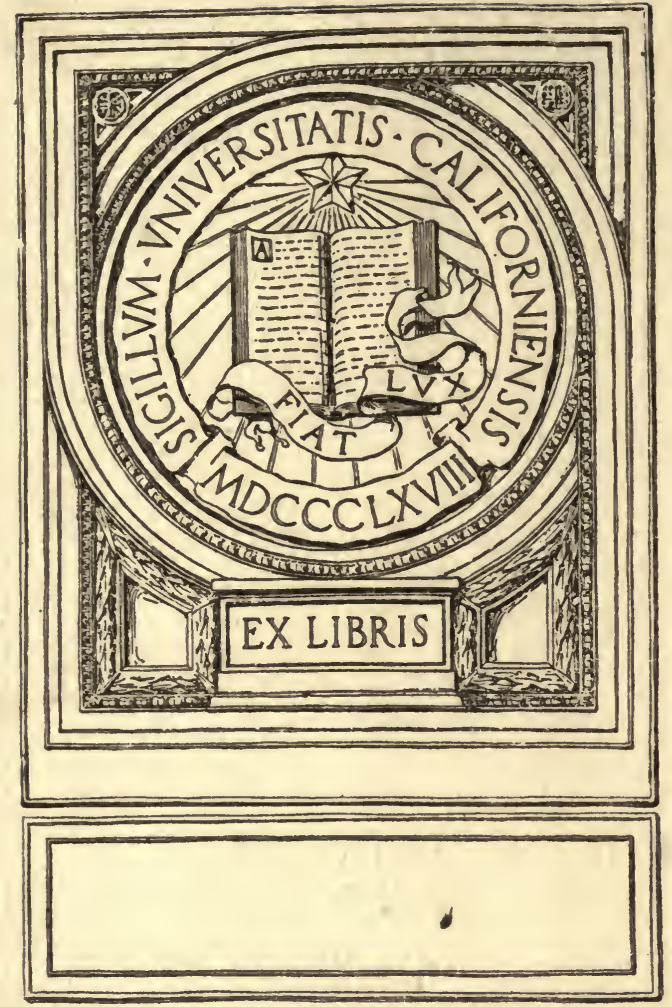



Digitized by the Internet Archive in 2007 with funding from Microsoft Corporation 



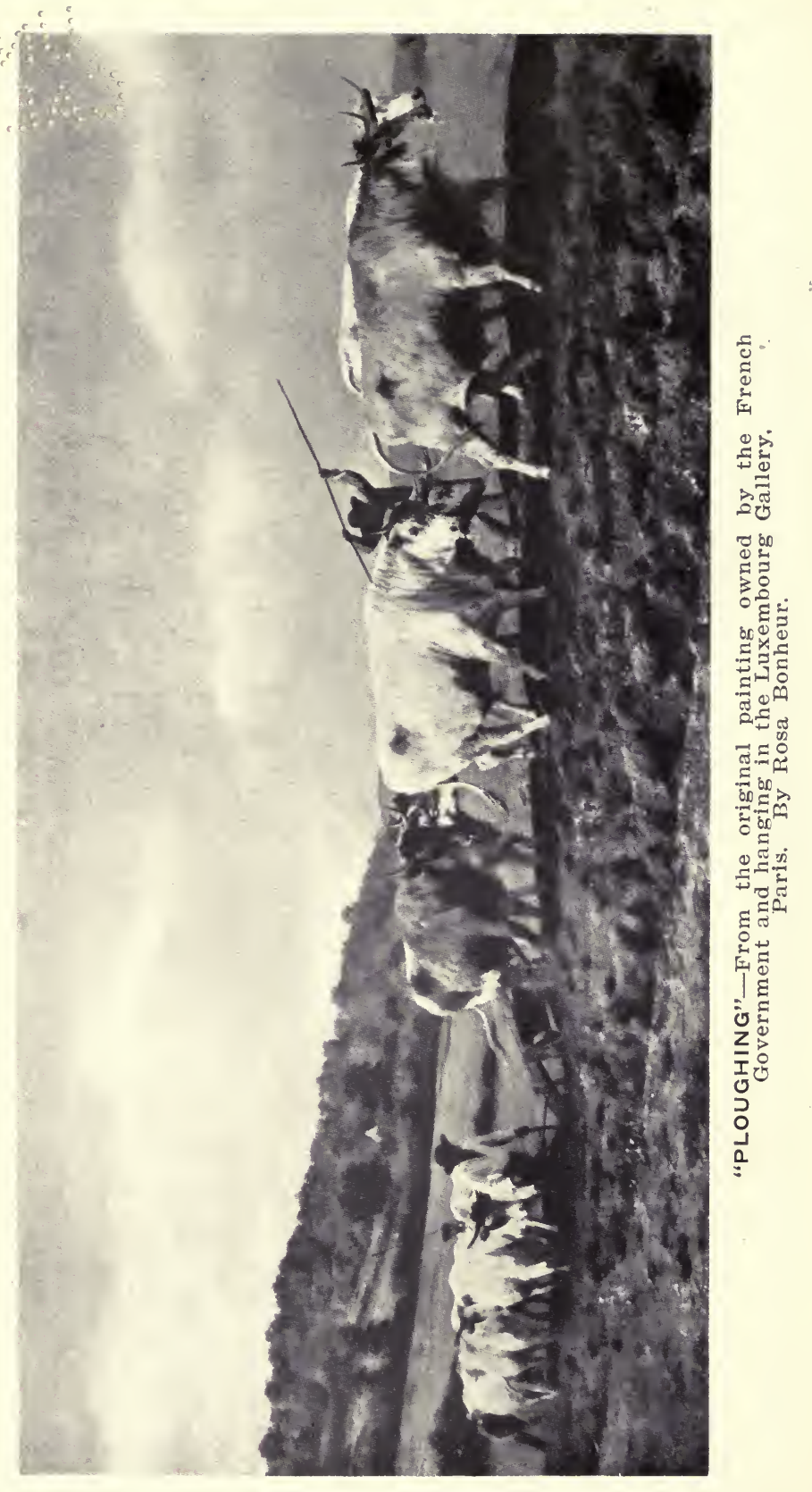




\section{FARM ACCOUNTS}

\section{A MANUAL FOR FARMERS}

AND THOSE DESIRING A

\section{Simple Method of Keeping Accounts}

\section{PREPARED FOR THE CLASSES OF THE SCHOOL OF AGRICULTURE UNIVERSITY OF MINNESOTA, AND ADAPTED TO HIGH SCHOOLS AND BUSINESS COLLEGES}

BY

$$
\text { J. A. }{ }_{\|} \mathrm{YE}
$$

Secretary of the Agricultural Department of the University of Minnepsota, and Author of Creaniery Accointing

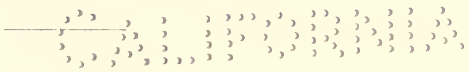

SECOND EDITION

PUBLISHED BY THE AUTHOR

ST. ANTHONY PARK

ST. PACL, MINN. 


$$
\begin{array}{r}
\text { HF } 5686 \\
.45 V 9 \\
1910
\end{array}
$$

Copyrighted 1906 by J. A. Vye

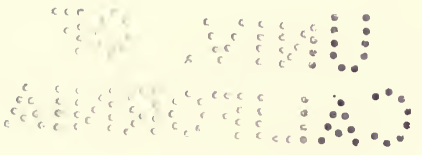


To the young, men and women on the farm, who are struggling with nature to yield up her treasures, this book is affectionately dedicated by the author. 



\section{PREFACE.}

Ever since the latter part of the fifteenth century, when the Venetian traders, the greatest merchants of their time, evolved a system of double entry book keeping, the subject of accounting has grown in breadth and importance until to-day no business of any extent is successfully carried on without the aid of a perfect system of accounting. Even the small trader in the country village recognizes its importance, while the farmer has hardly begun to appreciate the benefits that may be derived from a thorough understanding of his transactions gained only by a system of accounts.

Most of the efforts to adapt or improve the various methods of keeping accounts have been along lines employed by the great business concerns in our large cities. The tendency of the modern book keeping development has been to reduce the labor of the dealer who employs clerks and special book keepers to look after the details of his business.

With the soil replete with the food for regetable life, there seemed to be little necessity for careful husbandry; but as successive years of tillage depleted the earth of its richness the need for more knowledge of farming became apparent. With this depletion came man's determination to know more of nature and with the progress of civilization he has had better opportunities for advancing. He is learning that business success depends upon the ability to act at the proper time; that this ability is only acquired by gaining a complete insight into every detail of his affairs. He must, therefore, keep accounts. He must be thoroughly familiar with every phase of every enterprise 
he undertakes. If he is not, his decisions are not based upon understanding, but upon chance. Some feeble attempts have been made to adapt a system to his needs but only where the transaction involved was great enough to warrant the employment of a special book keeper has success been apparent. And these records were made more with a view of accounting for the wages due employees, purchases made, and monies received from the sale of products than for determining profit and loss on production.

This book is an attempt to provide a system of accounting directly applicable to all farm conditions; so simple that any man of ordinary ability can apply it; and so short that its value as a time-saver will at once be apparent. The data used as examples were taken from the operation of a farm in this state. Nothing has been changed for the sake of appearances. All the problems of farm accounting resulting from actual experience, have here been faithfully met, and the many vexatious details that must be carefully considered and heeded have been handled in a way that will appeal to all who have tried to accomplish the same results without knowing how it should be done. Even the preliminary practice work, such as cash, personal account with a neighbor, business account with poultry, etc., is taken from actual life and represents every-day transactions without any adornment to make them appear as if on dress parade. In short, the data are real, live actual records from the farm put into form as a guide to the farmer desiring to know how to keep an accurate account of his business. The day-book, the journal, and the cashbook usually considered indispensable to complete account. ing are discarded, and the records made direct on cards, which combine all the essential features of the foregoing books and the ledger as well. The essential features of this work have been used in the class room for a number of years with much greater success than when the older methods combining the use of the journal, day-book, cashbook, and ledger were used.

In the preparation of this volume grateful acknowledg- 
ment is made of the untiring efforts of Mr. C. I. Bingham, a student in the College of Agriculture, in collecting and arranging material for this work and in preparing forms, etc., for the printer, and to Mr. F. B. Headley, and Mr. E. C. Parker both of the Agricultural Division who have also given material assistance in supplying data taken from actual farm operations.

Grateful acknowledgment is made to The Bureau of Statistics of the United States Department of Agriculture for the collection of valuable data here used. Without such a comprehensive assemblage of facts concerning farm operations this work would not be possible. To W. M. Hays, Assistant Secretary of the National Department of Agriculture I wish to express my most grateful thanks for help and constant encouragement.

St. Anthony Park, St. Paul, Minn., May 1, 1906. 



\section{INTRODUCTION.}

This system provides for the use of properly ruled cards $5 \times 8$ inches in size to be kept in a cabinet or box, and but one account written on each card. It is based on the double entry system-an equality of debits and credits in the ledger. This is advocated as the best for farmers because it is comprehensive. It considers the entire business aspect of the farm. It does not confine itself to a few selected financial operations. Without considering all matters pertaining to his affairs, a farmer cannot gain the exact knowledge so necessary in determining the proper thing to do. To rise above the realm of chance, he must know.

However, if he doesn't know, and what is worse, doesn't care, and won't try to know, let him consent at least to keep a Cash Account. This will surely be the torch to lighten the way to a better and more complete understand. ing of his affairs.

The Enit system, with cards ruled and used as in the illustrations which follow, most nearly meets the demand for a convenient plan of farm accounting. The cabinet or box in which the cards are kept furnishes a permanent and secure place convenient for instant use or reference. The classifications can be made to suit the needs of any farm. Closed accounts are placed by themselves so that nothing but open accounts are at the front for daily use. For learning the principles of accounting, the Unit system as here illustrated, has proven both in private and class work to be more adequate and clear in every way than the old book plan, while the elimination of unnecessary processes makes it the most convenient and practical in every day work. 
The cards used in making a complete business record on the farm depend on the number and nature of the enterprises to be carried on. These consist of principal and auxiliary forms numerous enough to make easy the keeping of a clear and comprehensive record.

In the illustrations which follow the principal card form is the Original Entry Farm Ledger. On this form accounts are kept showing the debits, credits, and balances, pertaining to each department of the business and to each person dealt with on account. The auxiliary forms are the Statement Card used for inventories, trial balance, and business and financial statements; Report Card used for memoranda showing the labor time given the various enterprises and the yield and consumption by quantity of such products as yield themselves to such form of record; Dairy Statement Card used to record the weight of milk given by each cow at a milking; and the Feeding Statement Card used to record the weight and value of feeds fed to live stock.

The Hibbard family consists of man, wife, boy 19, boy 11, girl 17, and girl 15 years of age. The girls go to school in the village, driving in during good weather $2 \frac{1}{2}$ miles, otherwise boarding in town. The young boy goes to the district school. Father and youngest daughter sick during February and March, 1904. Older boy helps father run the farm. Makes money chiefly from dairying. Has cream separator and makes and sells butter in winter; in summer sells milk at creamery at so much per pound for butter fat. Most of his neighbors send milk to the city at 8c per gallon In summer and $10 \mathrm{c}$ in winter. He has about 100 acres in cultivation; pasture 37 acres; meadow 14.77 acres.

Has good house heated by furnace; good barn, machinery, etc; piano and good furniture. 


\section{CONTENTS.}

"Ploughing," (Illustration) .................. Frontispiece.

Preface $\ldots \ldots \ldots \ldots \ldots \ldots \ldots \ldots \ldots \ldots \ldots \ldots \ldots \ldots \ldots \ldots \ldots \ldots \ldots \ldots$ vii

Introduction $\ldots \ldots \ldots \ldots \ldots \ldots \ldots \ldots \ldots \ldots \ldots \ldots \ldots \ldots \ldots \ldots \ldots \ldots \ldots$

Students' Cash Account.......................... 1

Personal Account $\ldots \ldots \ldots \ldots \ldots \ldots \ldots \ldots \ldots \ldots \ldots \ldots \ldots \ldots$

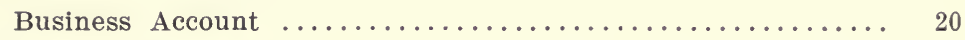

Complete Set of Accounts.......................... 27

Complete Business Record..................... 35

Practice Work, January.................... 38

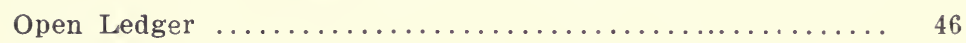

"Returning To The Fold," (Illustration)............. 67

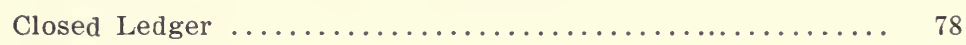

"The Escaped Cow," (Illustration) ................ 96

Práctice Work, February and March............... 97

Practice Work, April, May and June................ 111

Weights of the Bushel..................... 133

Materials used in Farm Accounts................... 135

Statutes Governing Weights and Measures in Minnesota..... 139

Pedigree and Note Form...................... 141

Answers to Preliminary Work.................. 142 



\section{FARM ACCOUNTS.}

\section{CHAPTER I.}

\section{STUDENT'S CASH ACCOUNT.}

The principles of accounting are easiest learned by practicing the record of business transactions which are familiar. Every student at school necessarily spends money. The charges for the various items of school expense, as board, books, book rent, and for such incidentals as clothing, stationery, postage, car fare and entertainment, require the fre. quent handling of money. The amounts thus spent by each student are important matters for record. Because these things are familiar to all, our first lesson illustrates the proper manner of writing an account of cash receipts and expenditures while at school.

\section{HOW TO RULE PAPER FOR AN ACCOUNT.}

An account may be written on any clean sheet of paper of suitable size, if properly ruled. For example a sheet of letter or examination paper may be ruled as follows: Draw a double head line across the paper one to two inches below the top. Then, beginning at the left-hand edge, measure in to the right five-eighths of an inch, and from this point three-eighths of an inch further in, and draw perpendicular lines through each of these points of measurement from the double head line to the bottom of the sheet. From the right-hand edge of the paper measure in to the left three-eighths of an inch, then five-eighths of an inch further in, then three-eighths of an inch further, then five-eighths of an inch further, drawing perpendicular lines through each

"Economy, not grasping stinginess, leads to success." 
of these points of measurement, as on the left side, making the second and fourth lines double. These measurements may be varied somewhat as the size of the paper requires. They will give the neatest appearance in the majority of cases and present a sheet similar to the page of an account book.

\section{HOW THE RECORD IS MADE.}

The illustration shows how the transactions of Student No. 1 during October should be entered in the account. The heading, "Cash," is written at the top of the page. The rulings have divided the page into columns which are to be used as shown in the illustration. The year is written in small figures at the top of the left-hand column. As transactions occur, the name of the month is written in the left-hand column, the day of the month in the narrow column on its right, an explanation in the wide column, and the amount in dollars and cents in one of the two money columns at the righthand side of the page. These money columns are divided into two parts. The wider part on the left is used for that part of the amount expressed in dollars, while the narrow part to its right is used for that part of the amount expressed in cents.

It is fundamental that the student should understand at the beginning how to determine in which of the money columns the amount which the transaction involves should be entered. He should think of "cash" as a person, and of the account as being his account with a person named "Cash."

With the idea in mind as just stated, when the account is opened, any money on hand is given over to "Cash" and "Cash" is therefore in debt for it. When money is received for labor, from home or from any other source, "Cash" becomes indebted for each amount as received. This establishes the principle that an account should be debited with what it receives. By custom the left-hand column is used

No great work worthy of praise or memory but came out of a poor cradle.-Dr. Johnson. 
for the debit amounts. The abbreviation "Dr." is used to signify debit.

Since a debtor reduces the amount of his indebtedness by such amounts as he returns or pays out in favor of the one who credits him, it follows that "an account should be credited with what it gives." When money is paid out the record should be so made that payments will stand by themselves in contrast to the amounts received.

By custom the amounts of payments are placed in the right hand money column. The abbreviation "Cr." is used to signify credit.

\section{BALANCING.}

It is a business-like custom to go over a cash account at stated times to determine its balance. This balance is the difference between the debit and credit sides of the account, and should be exactly equal to the amount of cash on hand. In the affairs of a student it is good practice to balance the cash account at the end of each month. The illustration shows a correct entry for every transaction during October in the first student's account, and the balance of cash left over for his use in November. The illustration and the memorandum of transactions for October should be carefully studied. The student should be able from this study to tell readily in class what transactions should be debited and what credited during the month of October.

\section{PRACTICE WORK.}

Rule a sheet according to the foregoing directions for ruling. It will then resemble the illustration. Beginning with

Note.-Cash simply represents value, and is not necessarily a value. It is a medium of exchange. All the cash you have should therefore be held as in debt to you until you have paid it out.

Note. A cash account shows the amount of cash received and cash paid during a certain time. As it is impossible to pay more cash than is received, it follows that if at any time the amount shows that there is a difference between the total amount received and the total amount paid, this difference should be equal to the amount of cash on hand. It is customary to speak of this difference as a "balance." 
the cash balance left over from October, make entries for all the November transactions, and balance the account at the close of the month, as is done in the illustration. In like manner make a correct account for each succeeding month for the school year, beginning each with the balance left on hand from the next preceding month. When the first student's account has been completed, make out the accounts for those which follow.

\section{STUDENT NO. 1, SCHOOL YEAR 1902-03.}

Oct. 1 , cash on hand $\$ 50.63$; paid for railroad fare $\$ 5.04$; street car fare 5c; drayage of trunk $25 \mathrm{c} . .$. Oct. 2, paid school fees as follows: Hospital fee 50c; board $\$ 12.00$; deposit $\$ 5.00$; incidental fee $\$ 1.50 \ldots$... Oct. 4 , bought note book $15 \mathrm{c}$; drawing paper $5 \mathrm{c}$; pencil 5c... Oct. 6 , paid for soap $10 \mathrm{c}$; shoebrush $15 \mathrm{c}$; car fare $10 \mathrm{c} . .$. Oct. 7 , lecture tickets $\$ 1.50 \ldots$. Oct. 9, sold Sergeant's stripes 50c.... Oct. 12 paid for car fare $20 \mathrm{c}$; church contribution 5c... Oct. 13, paid for postage 6c... Oct. 18, paid for tablet 5c; postage 8c; class colors $25 \mathrm{c} . .$. Oct. 20, paid for fruit $25 \mathrm{c} . .$. Oct. 22, paid for key ring 5c... Oct. 26, paid church contribution 25c.... Oct. 27, paid for pocket comb 5c; tie 50c; car fare $10 \mathrm{c}$... . Oct. 31, paid for map 10c; clothing $72 \mathrm{c}$; books $\$ 3.20$.

Nov. 2, paid for car fare $15 \mathrm{c} . .$. Nov. 4 , paid for composition paper 5́c... Nov. 5, paid for board $\$ 12.85 . .$. Nov. 9, paid for cleaning watch $\$ 1.50$; car fare $25 \mathrm{c} .$. Nor. 11 , paid for postage $4 \mathrm{c} .$. ..Nov. 13 , paid for tablet $25 \mathrm{c}$; entertainment $10 \mathrm{c} . .$. Nov. 14, paid for car fare $10 \mathrm{c}$; lecture $25 \mathrm{c}$; lunch $10 \mathrm{c} . .$. Nov 17 paid for car fare 10c; pencil 5c; barber $25 \mathrm{c}$ Nov. 21, paid for lecture tickets $75 \mathrm{c}$; car fare $10 \mathrm{c}$; lunch $15 \mathrm{c} . .$. Nov. 22 , paid for shoe repairs $60 \mathrm{c}$; tablet $5 \mathrm{c} . .$. Nov. 24 , paid for money order $25 \mathrm{c}$; car fare $20 \mathrm{c} .$. . Nor. 25 , received from liome $\$ 46.00$.... Nov. 27 , paid for school supplies $48 \mathrm{c}$; car fare $10 \mathrm{c} . .$. Nov. 28 , paid for Sergeant's stripes $50 \mathrm{c}$.

Dec. 1 , paid for watch chain $\$ 1.00$; cuff buttons $50 \mathrm{c}$;

"Discontents arise from our desires oftener than from our needs.", 


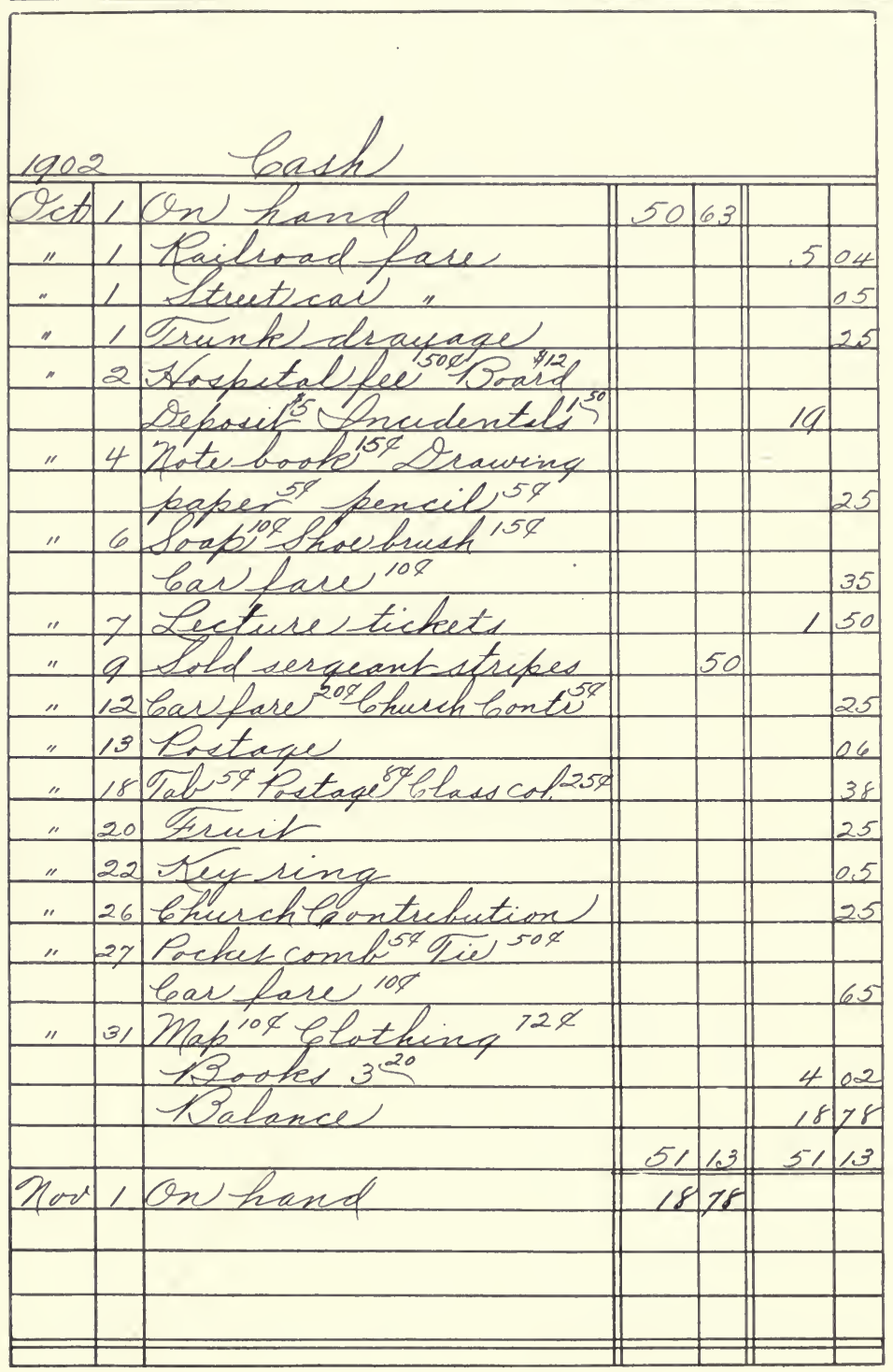

glasses $\$ 3.50$; physician $\$ 4.75$; car fare $20 \mathrm{c} . .$. Dec. 2 , paid car fare $10 \mathrm{c} . .$. Dec. 4 , paid for board $\$ 12.30$; postage $10 \mathrm{c}$; "He that pelts every barking dog must pick up a great many stones." 
received for work $\$ 1.38 . .$. Dec. 6, paid for judging book $\$ 1.05$; tablet 6c; clothing 37c... . Dec. 7 , paid for car fare $15 \mathrm{c}$ Dec. 8 , paid for money order $57 \mathrm{c}$; car fare 10c; tablet $5 \mathrm{c}$; pictures $30 \mathrm{c} . .$. Dec. 9 , paid for pencil holder $15 \mathrm{c} . .$. Dec. 11, received for use of lecture ticket $10 \mathrm{c}$; paid for iron $25 \mathrm{c}$; Prohibition League 15c.... Dec. 12, paid for spread 7c; car fare $10 \mathrm{c} . .$. Dec. 15 , paid for neckties $\$ 1.00$; collars $25 \mathrm{c}$; fruit $25 \mathrm{c}$; horse book $\$ 1.00$; car fare $15 \mathrm{c}$; received money order 22c....Dec. 18, paid subscription to Breeders' Gazette for one year $\$ 1.00$; confectionery $10 \mathrm{c}$; fountain pen $\$ 1.80 \ldots$ Dec. 19 , paid for railroad ticket home and return $\$ 6.70$; car fare $10 \mathrm{c}$.

Jan. 1, bought present for mother $75 \mathrm{c} . .$. Jan. 2, received from home $\$ 12.00$; paid for board $\$ 7.79$; car fare $5 \mathrm{c}$; incidental fee $\$ 1.50$; expenses at stock sale $95 \mathrm{c} . .$. Jan. 3 , paid for account books 35̃c; ruler 5c....Jan. 5, paid for postage 20c....Jan. 8, bought note book 5c...Jan. 11, paid for rent of apron 5c....Jan. 12, paid for shoe strings 5c; blacking $10 \mathrm{c}$; matches $2 \mathrm{c}$; car fare $10 \mathrm{c} . .$. Jan. 14, paid for ink $10 \mathrm{c} . . . J a n .17$, paid for confectionery $10 \mathrm{c}$; car fare $10 \mathrm{c} . .$. Jan. 20, paid for eraser 5c....Jan. 21, paid Y. M. C. A. dues $\$ 1.00 \ldots$. Jan. 25, paid for dinner $15 \mathrm{c}$; car fare 5c.

Feb. 1, paid for clothing $\$ 1.00$; car fare 5c.... Feb. 2 , paid for pictures $50 \mathrm{c}$; picture holder $10 \mathrm{c}$; sundries $42 \mathrm{c}$; car fare 10 c.... Feb. 5, paid car fare $10 \mathrm{c}$....Feb. 8, paid for car fare $10 \mathrm{c}$; peanuts 5c....Feb. 11, paid Y. M. C. A. dues 50c... Feb. 14, received from home $\$ 12.00$; paid for board $\$ 12.16$ Feb. 16, paid for trunk rope 39c; fruit 5c; barber 25c; literary society $5 \mathrm{c}$; car fare $10 \mathrm{c} . .$. Feb. 23 , paid for pencils 7c; tablet $10 \mathrm{c}$; clothing $\$ 2.00 \ldots$ Feb. 24 , paid for postage $31 \mathrm{c}$....Feb. 25, paid class dues $20 \mathrm{c}$; envelopes $5 \mathrm{c}$; received from home $\$ 20.00$; loaned to room-mate $\$ 5.00$.

Mar. 1, paid car fare 10c.... Mar. 12, paid for board $\$ 11.48$; received for military books 35c; Sergeant's stripes $50 \mathrm{c} . .$. Mar. 13, paid for Britton's Manual $\$ 2.00 \ldots$ Mar. 16 , paid for belt $25 \mathrm{c}$; barber $25 \mathrm{c}$; candy $10 \mathrm{c}$; car fare $10 \mathrm{c} . .$. Mar.

He who is afraid of doing too much, always does too little.-Hubbard. 
17 , received for trunk rope $15 \mathrm{c}$; paid for basket ball tickets $15 \mathrm{c}$; lunches $45 \mathrm{c}$; car fare $35 \mathrm{c} . .$. Mar. 18 , received from room mate amount loaned him on Feb. $25 \$ 5.00$; paid for fruit 15c... Mar. 19, received from secretary deposit $\$ 8.80$; paid for test tubes $6 \mathrm{c} . .$. Mar 20 , paid for collars $25 \mathrm{c}$; car fare $20 \mathrm{c}$; clothing $50 \mathrm{c}$; railroad ticket home $\$ 5.01$.

\section{STUDENT NO. 2, SCHOOL YEAR OF 1902-03.}

Oct. 1 , cash on hand $\$ 38.10$; paid for railroad fare $\$ 4.18$; car fare 5c; headache capsules 25c; penknife 50c; drayage for trunk 25c.... Oct. 2, paid for board and school fees $\$ 20.00$; parasol $75 \mathrm{c}$; curtain $65 \mathrm{c}$; ribbons $38 \mathrm{c}$; sundries 20c; napkins 52c; car far 10c; postage 4c.... Oct. 3, paid for botany note book 15c; car far 5c... Oct. 5, paid for postage $3 \mathrm{c} . .$. Oct. 6 , paid for stationery $30 \mathrm{c}$; postage $10 \mathrm{c}$; literary society tax $5 \mathrm{c}$; eraser $5 \mathrm{c}$; note book $5 \mathrm{c} . .$. Oct. 9, paid for trunk storage $25 \mathrm{c} . .$. Oct. 10 , paid for ruler $5 \mathrm{c}$; tablet 5c.... Oct. 12, paid for car fare $10 \mathrm{c}$; church collection 10c.... Oct. 13, paid for lecture course ticket $75 \mathrm{c}$; pocket book 48c; cap 75c; lunch $10 \mathrm{c}$; car fare $10 \mathrm{c} . .$. Oct. 19, paid car fare 5c.... Oct. 20, paid for class colors $25 \mathrm{c}$; collar $5 \mathrm{c}$; emery bag $5 \mathrm{c} . .$. Oct. 25, paid for sewing box $15 \mathrm{c} . .$. Oct. 26 , received from brother $\$ 15.00$; paid for car fare $10 \mathrm{c}$; collection 5c.... Oct. 27 , clothing $\$ 1.40$; sewing book 55c; tape line 5c.

Nov. 3, paid for postage 10c; pens 5c; Y. W. C. A. dues $25 \mathrm{c}$; board $\$ 12.85 . .$. Nov. 5 , paid for account books $50 \mathrm{c} . .$. Nor. 6, paid Y. W. C. A. 6c.... Nov. 9, paid for car fare $10 \mathrm{c}$; collection 5c.... Nov. 10, paid for postage 4c; cotton 5c... Nov. 13, paid for entertainment ticket $10 \mathrm{c}$.... Nov. 16, paid car fare $10 \mathrm{c} . .$. Nor. 17 , paid for postage $2 \mathrm{c} .$. Nov. 23, paid for car fare $5 c$; collection $5 c$; publication society $25 \mathrm{c}$; Nov. 24, paid for postage 2c.... Nor. 26, paid for stationery 20c... Nov. 27, paid for postage 2c... Nov. 29, received from home $\$ 15.00$. 
Dec. 1 , paid for clothing $\$ 1.49$; postage $10 \mathrm{c}$; eraser $5 \mathrm{c} . .$. Dec. 2 , paid for board $\$ 12.30 \ldots$ Dec. 6 , paid literary society dues $10 \mathrm{c} . .$. Dec. 8 , paid for postage 4 c.... Dec. 12, paid for postage 2c.... Dec. 19, paid literary society tax 15c; post. age 5c.... Dec. 20 , received from home $\$ 6.00$; paid for car fare $20 \mathrm{c}$; railroad ticket home and return $\$ 5.60 \ldots$ Dec. 22 , paid for underwear $\$ 1.00$; present $50 \mathrm{c}$; loan to brother 70c. .

Jan. 2, paid for car fare 5c.... Jan. 3, received from home $\$ 12.00$; paid for baggage transfer $25 \mathrm{c}$; board $\$ 11.05 . .$. Jan. 6, paid for pencil 15c; note book 5c..Jan. 11, paid for car fare $10 c$; collection 5c....Jan. 12, paid for postage $10 \mathrm{c}$; car fare $10 \mathrm{c} . . . J a n .26$, paid for darning cotton $5 \mathrm{c}$; postage 2c....Jan. 2S, paid Y. W. C. A. dues 25c.

Feb. 2, received from home $\$ 15.00$; paid for mending shoes $35 \mathrm{c} . .$. Feb. 5, paid for board $\$ 12.04 \ldots$ Feb. 6, gave Y. W. C. A. 10c....Feb. 8, paid for car fare $10 \mathrm{c}$; collection $2 c \ldots$ Feb. 12 , paid for car fare $20 \mathrm{c} \ldots$ Feb. 13 , paid for literary pin 50 c.....Feb. 16 , paid for clothing $\$ 4.00$; car fare $10 \mathrm{c} . .$. Feb. 17, paid for postage $2 \mathrm{c}$.

Mar. 1, paid for postage $10 \mathrm{c} . .$. Mar. 6 , received from home $\$ 14.00 \ldots$ Mar. 7 , paid for board $\$ 11.48$; medicine $65 \mathrm{c}$ Mar. 8, paid for car fare $10 \mathrm{c}$; collection $10 \mathrm{c} \ldots$...Mar. 9, paid for pictures $30 \mathrm{c}$; car fare $10 \mathrm{c}$; sundries $15 \mathrm{c} . .$. Mar. 14, paid literary society 5c; Y. W. C. A. 6e....Mar. 17, paid for car fare $10 \mathrm{c}$; received from home $\$ 1.00 \ldots$ Mar. 19 , paid for car fare 5c; clothing $55 \mathrm{c}$; gardening book 25c; comb $9 c$; paper $3 c$; received from secretary deposit and excess payment on board $\$ 8.66 \ldots$ Mar. 20 , paid for railroad fare home $\$ 4.18$; car fare $5 c$.

\section{STUDENT NO. 3, SCHOOL YEAR 1904-05.}

Oct. 3, cash on hand $\$ 49.18$; paid for $\mathrm{R}$. R. fare $\$ 5.15$; supper 30c.... Oct. 4, paid for meal ticket $\$ 11.85$; school fees $\$ 5.00$; hospital fund $75 \mathrm{c}$; deposit with secretary $\$ 5.00$;

A man can not leave a better legacy to the world than a well educated family.-Thomas Scott. 
book rent 25̃c; account books 50c; drawing paper כ̌c.... oct. 5, paid for books $\$ 2.15$; ruler $15 \mathrm{c} . .$. Oct. S, paid for lecture ticket $\$ 1.00$. . Uct. 10 , paid deposit on military suit $\$ 2.00$; car fare $10 \mathrm{c}$; drawing ink and pens 56c.... Oct. 16, paid for dinner $46 c^{\circ}$; car fare $10 \mathrm{c} . .$. Oct. 19 , paid for class colors 25๕.... Oct. 23, paid for temnis shoes $\$ 1.25$; car fare $15 \mathrm{c}$; candy $10 \mathrm{c} . .$. . Oct. 24 , received for labor $65 \mathrm{c} . .$. Oct. 25 , received from home $\$ 20.00$.... Oct. 29, paid for Nor. meal ticket \$12.00; Oct. 31, received for labor 65̌c.

Nor. 3, paid for apples $30 c$; car fare $150 \mathrm{c} . .$. Nor. 7, received for labor 6.5 ; paid balance on military suit $\$ 9.25$; car fare 10c; popcorn 5c; gloves 25c.... Nov. 9, received for labor 12c..... Nov. 12, paid for suspenders 50c.... Nor. 13. paid for candy $10 \mathrm{c} . .$. . Nor. 14 , paid for repairing shoes $\$ 1.00$; hair cut 25̄c; paper อ̆c.... Nor. 18, paid for collars 25c; clothing 25e; lamp shade $15 \mathrm{c} . .$. Nov. 21, received for labor 75 c.... Nov. 23, paid for car fare $20 \mathrm{c}$; stationery $9 \mathrm{c}$. ..... Xor. 25, sold sheet drawing paper 1c; paid railroad fare to chicago and return $\$ 5.00 \ldots$ Nor. $2 \pi$, borrowed of brother \$2.00..... Nor. :30, paid incidental expenses on Chicago trip \$5.17.

Dec. 2, received from home $\$ 25.00$; paid for meal ticket $\$ 8.20$; literary society tax $10 \mathrm{c}$; returned to brother $\$ 2.00$ Dec. 6, paid for pictures 50c; drawing paper 5c... Dec. 7 , paid for paper 5̌c.... Dec. 10, paid for candy $10 \mathrm{c}$... Dec. 12, paid for book 25c: car fare and lunch $3.36 . .$. Dec. 14. paid for postage 2c.... Dec. 1S, paid for car fare $20 \mathrm{c}$; candy 106.... Dece. 19, paid for car fare 10c; charity 10c; clothing 60c; presents $\$ 1.80 \ldots$. Dec. 22, paid for hair cut 2ōc... Deс. 2:3, paid for card ledger 25c. . . Dec. 24, received from home $\$ 2.15$; paid for subscription to Christian Herald $\$ 2.00$; ink 15̆c; railroad fare home and return $\$ 6.90$; breakfast 50c.... Dec. 25, paid Sunday school collection 5c.

Jan. 1, paid Sunday school collection 5c....Jan. 2, received from father $\$ 22.00 . . . . J a n .3$, paid for breakfast $30 \mathrm{c}$; meal tickot and hospital fee $\$ 13.00 \ldots .$. Jan. 4 paid for note 
book 10c....Jan. 5, paid for candy 5c....Jan. 6, paid for paper 1c; class supper 25c.... Jan. 8, paid for car fare $10 \mathrm{c} . .$. Jan. 9 , paid for pictures $\$ 2.00$; paper $5 \mathrm{c}$; car fare $10 \mathrm{c} . .$. Jan 11, paid for car fare $15 \mathrm{c} . .$. Jan 13 , paid for picture $15 \mathrm{c}$... .Jan. 16 paid for car fare $15 \mathrm{c}$.... Jan. 23, paid for pictures $\$ 1.50$; ruler and tri-square $72 \mathrm{c}$; car fare $10 \mathrm{c}$; watch fob 50c; apples 50c; tablet $12 \mathrm{c}$; Flinch $35 \mathrm{c} . .$. Jan. 24, paid for postage $26 \mathrm{c}$; paper $2 \mathrm{c} . . . \mathrm{Jan} .27$, received from home $\$ 20.00$; paid for lemon $3 c$; meal ticket $\$ 11.48 \ldots$. .Jan. 30 , paid for medicine $\$ 1.00$; lemons $20 \mathrm{c}$; paper $10 \mathrm{c}$.

Feb. 1, paid for eraser 5c....Feb. 3, paid for doctor $\$ 1.50$; medicine $45 \mathrm{c}$; dinner $20 \mathrm{c}$; barber $35 \mathrm{c} . .$. Feb. 4, paid for coat hanger 5c....Feb. 6, sold envelopes 4c...Feb. 12, paid for book $25 \mathrm{c}$; supper $25 \mathrm{c}$; car fare $10 \mathrm{c} . \ldots$ Feb. 13 , paid for car fare $30 \mathrm{c} . .$. Feb. 14, paid for entertainment ticket $25 \mathrm{c}$; Feb. 16, paid for theater ticket $50 \mathrm{c}$; car fare $15 \mathrm{c}$; candy $10 \mathrm{c} . .$. Feb. 18, paid for basket ball ticket $20 \mathrm{c}$; bolts 1 б̌ Feb. 22, paid for apples, 50c;....Feb. 23, paid for wagon jack 25c....Feb. 24, received from home $\$ 20.00 \ldots$...Feb. 25 , paid for file $15 \mathrm{c}$; car fare $20 \mathrm{c}$; candy $10 \mathrm{c} . .$. Feb. 27 , paid for meal ticket $\$ 9.02$; car fare $15 \mathrm{c}$; paid for present $30 \mathrm{c}$.

Mar. 5, paid for car fare $10 \mathrm{c} . .$. Mar. 6, paid for car fare 10c... Mar. 9, paid for entertainment ticket 25c... Mar. 10, paid for picture 50c....Mar. 11, paid for basket ball ticket 10c....Mar. 12, paid for car fare $10 \mathrm{c} \ldots$... Mar. 13, paid for present 25c; hair cut 25c; candy 10c....Mar. 14, paid for book 55c.... Mar. 15, paid Y. M. C. A. dues 50c....Mar. 16, paid for clothing 25c....Mar. 20, paid expense of trip to Stillwater $\$ 2.20 \ldots$ Mar. 21 , paid for car fare and lunch $28 \mathrm{c}$ ....Mar. 22, received from secretary, return of deposit, $\$ 5.00$; paid for cur fare 5c; railroad fare home $\$ 5.15$.

\section{PERSONAL ACCOUNT.}

A personal account is a record of business transactions with an individual. It is made for the purpose of knowing what is due you or the individual. It may be kept in many

A wise man changes his mind, a fool never.-Sp. 
different ways. The most common and convenient way is to rule a sheet of paper like that for an account described on page 1 . At the head of this page write the name of the person with whom you are dealing. Make a record at the left when he gets something from you and does not pay for it. Make a record at the right when he gives you something without receiving pay for it. A complete record consists of the date of the transaction, the name and quantity of the something exchanged and its agreed value. Anything placed on the left is a debit. Anything placed on the right is a credit. Debit an account with what it costs. Credit an account with what it gives.

The following memoranda will serve to illustrate the man. ner of recording these transactions and will also familiarize the student with them. Let the student write up these rec. ords, using the model form as a guide.

\section{GENERAL DIRECTIONS.}

The student should read carefully and thoughtfully every direction given preceding each step in the work.

Let him first rule paper as directed for the preliminary example-Cash. Let him read each item separately and think how it should be recorded, then compare his mental idea with the illustrated example following. After finishing the example in this manner, place a piece of paper over the illustration, if it is in view, and work the example as best he can on the ruled form. When this has been done, compare it with the illustrated example in the book. Make the necessary corrections, rule another sheet, work out the next example direct from data to ruled sheet, and submit the result to the teacher. These directions should be followed with each example.

\section{A FARMER'S ACCOUNT WITH A HIRED MAN.}

Mar. 29, 1901, I hired John Moore to work eight months from date at $\$ 16$ per month for the first four months and

Counsel after action is like rain after harvest.-Dan. 
$\$ 24$ per month for the second four months... April 23, paid him cash $\$ 1$...April 29, credited him with 1 month work $\$ 16 \ldots$... May 5, paid him by eheck $\$ 15 \ldots$ May 19 , bought necktie for him $25 \mathrm{c}$. . . May 25 , paid for his laundry $29 \mathrm{c} . .$. May 29, credited him with one month work $\$ 16 \ldots$ May 30 , paid him cash $\$ 10$. . . May 31 , paid him by check $\$ 6$. . . June 8, paid him by check $\$ 20 \ldots$. June 29 , credited him with 1 month work \$16....July 29 credited him with 1 month work $\$ 16 \ldots$...Aug. 2, paid him by check $\$ 16 \ldots$ Aug. 15 , paid him by check $\$ 5 . .$. Ang. 16 , credited him with value of bran and shorts which he paid for in my absence $\$ 9.50 \ldots$ Aug. 29 , credited him with 1 month work $\$ 24 \ldots$ Sept. 13 , paid him cash $\$ 2 \ldots$ Sept. 20 , paid him by check $\$ 20 \ldots$ Sept. 29 , credited him with 1 month work $\$ 24 \ldots$ Oct. 10 , paid him cash $\$ 1$... Oct. 16 , paid him by check $\$ 25$. . . Oct. 29 , credited him with 1 month work $\$ 24 \ldots$ Nor. 13 , paid him by check $\$ 24 \ldots$ Nov. 24 , paid him cash $\$ 15$. . . Nov. 25, bought two shirts for him $\$ 1$... Nov. 29, credited him with 1 month work $\$ 24 \ldots$ Dec. 7 , credited him with three days' work $\$ 2.50$; paid him by check $\$ 10.46$.

\section{AN ACCOUNT WITH A FARM NEIGHBOR.}

April 10, 1901, I sold F. R. Billings 1 hog weighing 340

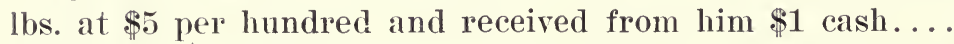
April 25, received check from him for $\$ 16 \ldots$ Oct. 17 , cred. ited him with 1 day labor unloading lumber, $\$ 1.50 \ldots$ Dec. 15, credited him with board of my day man $\$ 1 \ldots$ Dec. 22 , credited him with board and washing $\$ 3.25 \ldots$... Feb. 1, cred. ited him with board and washing for my month man $\$ 9.30$; 2 days' labor $\$ 2.50 ; 2 \frac{1}{2}$ tons hay $\$ 12.50 \ldots$ Feb. 5, paid him by check $\$ 16.50 \ldots . . A p r i l 1$, credited him with board and washing for my month man during February and March $\$ 19.10$; $\frac{1}{2}$ day labor $50 \mathrm{c}$; paid him by check $\$ 33.15$.

\section{AN ACCOUNT WITH NEIGHBOR NO. 2.}

On Mar. 6, 1900, bought of John Calendar on account $22 \frac{1}{2}$ bushels corn at 25c....Mar. 12, sold on account 12 bushels

A favor becomes old sooner than any other thing.-M. Greek. 
FARM ACCOUNTS.

13

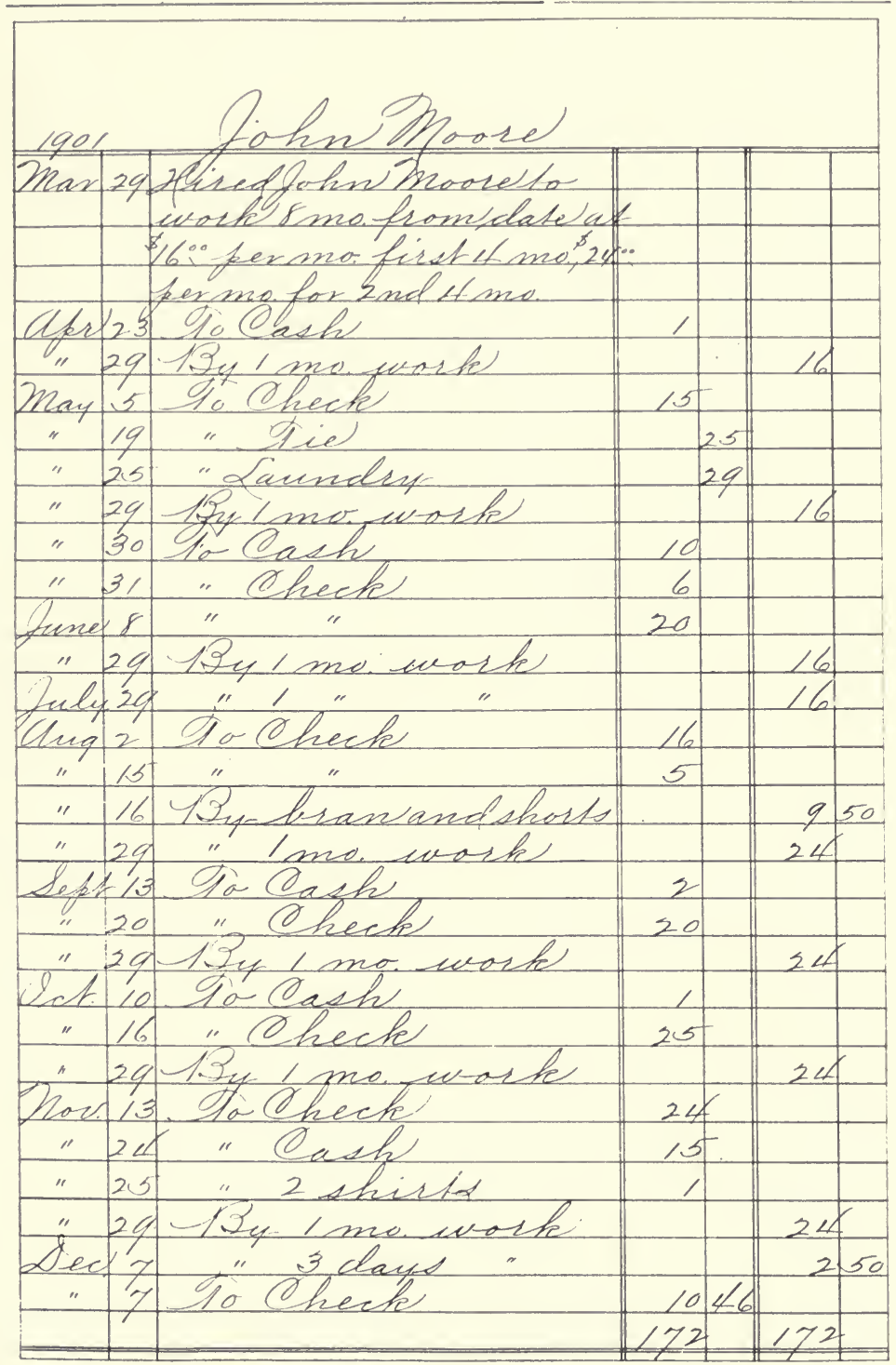

of seed wheat at $\$ 1 \ldots$. April 18 , bought of him on account 6.5 lbs. timothy at $3 \frac{1}{4} \mathrm{c}$... May 6 , sold him strawberries on

"A fool may make money but it requires a wise person to spend it." 




account $35 c .$. May 10 , paid for soldering his milk can $10 \mathrm{c}$. ....July 20 bought of him on account $19 \frac{1}{2}$ bushels of corn

Make it a point never to complain.-Disraeli. 
at $30 \mathrm{c} . . .4 \mathrm{dug}$. 17, bought of him on account $256-7$ bushels of corn at 30c...Aug. 31, let him have on account 20 lbs. twine at $10 \mathrm{c} . .$. Sept. 1 , he returned to me $20 \mathrm{lbs}$. twine at 10 c.... Sept. 28 , gave him cash $\$ 9.14$.

Jan. 17, 1901, paid his subscription to the Minneapolis Journal for three months and charged to his account $\$ 1$ ...June 3, received cash of him $\$ 1 \ldots$ June 25 , let him have 5 pieces $2 \times 4,16 \mathrm{ft}$. long at $\$ 18$ per thousand... July 20 , let him have $30 \mathrm{lbs}$. linseed oil and can*... Sept. 9, he returned 5 pieces $2 \times 4,16 \mathrm{ft}$. long, at $\$ 18$ per thousand... Sept. 21, bought of him on account $\frac{1}{2}$ of dressed pig $\$ 1$, and 4 live pigs weighing $191 \mathrm{lbs}$. at $\$ 5.65$, and $\frac{1}{2}$ mower casting $\uparrow \$ 1.75 . .$. Nov. 23, gave him cash $\$ 3$.

Feb. 8,1902 , paid him by check $\$ 10.54$, and sold him 1 peck $\left(\$ \frac{1}{2}\right.$ lbs.) popcorn at $3 \mathrm{c}$ per $1 \mathrm{~b} \ldots$...April 10 , bought of him on account 1 load of oat straw $\$ 2 \ldots$ June 30 , credited him with pasture for colt $\$ 2$. Give standing of account.

\section{A RECEIPT.}

A receipt is a written acknowledgment of the delivery of goods or value. It consists of the name of the place, the date, usually the words "Received of," the name of the party delivering the value, the name of the thing delivered, for what purpose delivered, and the signature of the party receiving the value.

Write receipts for the following exercises, using the model on page 17 as a guide:

April 23, 1901, paid John Moore cash $\$ 1$. May 5, 1901, paid John Moore cash $\$ 15$. May 30, 1901, paid John Moore cash $\$ 10$.

\section{A BILL.}

A bill is a statement showing that the ownership of value has been transferred from one party to another. It consists

*Linseed oil mills usually consider $7 \frac{1}{2} \mathrm{lbs}$. of linseed oil to the gallon. Charge Calendar at $55 \mathrm{c}$ per gallon and $25 \mathrm{c}$ for the can.

†The undivided half. The two men owned the mower jointly.

Better with the wise in prison than with fools in paradise.-Ger. 
of the name of the place of transfer, date, usually the words "Bought of" or "Sold to," the name of the party transferring the value, a description of the value and the name of the party to whom transfer has been made. It is usually mailed to the new owner of the goods or value. It is made out by the party transferring the value. It is sometimes receipted by writing on its face the words "Received Payment" and the signature of the party making it out.

Bill and receipt the transaction with John Moore Nov. 25, 1901, using model on opposite page as a guide.

Bill the transaction of April 18, 1900, page 13 .

Bill the transaction of July 20, 1900, page 14 .

Bill the transaction of Aug. 17, 1900, page 15.

Bill the transaction of sept. 21, 1901, page 15 .

\section{RALPH PALMER.}

July 22, 1904, hired Ralph Palmer to work at haying and to do other work about the place till harvest at $\$ 1.00$ per day and board....July 31, my time book shows he has worked 7 days at $\$ 1.00 \ldots$ Aug 7 , bought gloves for him $\$ 1.00 \ldots$ Aug. 11, bought tobacco for him 10c... Aug. 17 , bought tobacco for him 20c....Aug. 22, bought tobacco for him 10c....Aug. 31, my time book shows that he has worked this month $6 \frac{1}{2}$ days at $\$ 1.00$; and $17 \frac{1}{2}$ days at the harvest rate of $\$ 1.75$.... Sept. 2, bought tobacco for him $20 \mathrm{c} . .$. Sept. 6, bought tobacco for him 30c.... Sept. 19, bought for him overalls $85 \mathrm{c}$; and matches $5 \mathrm{c} . .$. Sept. 21 , gave him check for $\$ 5.00$; Sept. 22 , bought for him shoes $\$ 5.00$; socks $25 \mathrm{c} . .$. Sept. $30, \mathrm{my}$ time book shows that he has worked this month $4 \frac{3}{4}$ days until the end of harvest at $\$ 1.75$; $7 \frac{1}{4}$ days between harvest and threshing at $\$ 1.00$; and $10 \frac{1}{2}$ days' threshing at $\$ 2.00 \ldots$. Oct. 1 , bought tobacco for him 20c.... Oct. 6, bought tobacco for him 45c... Oct. 31, my

It takes ten pounds of common sense to carry one pound of learning. -Persian. 
FARM ACCOUNTS.

17

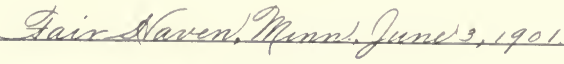
Pecuived of fohow balendar.

Cone Dollas

to apply ontacionet

false

Tair Waven, Minn, defkq, 1904

Pecived of fohm balendar

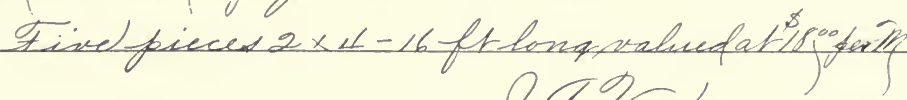

faldorel

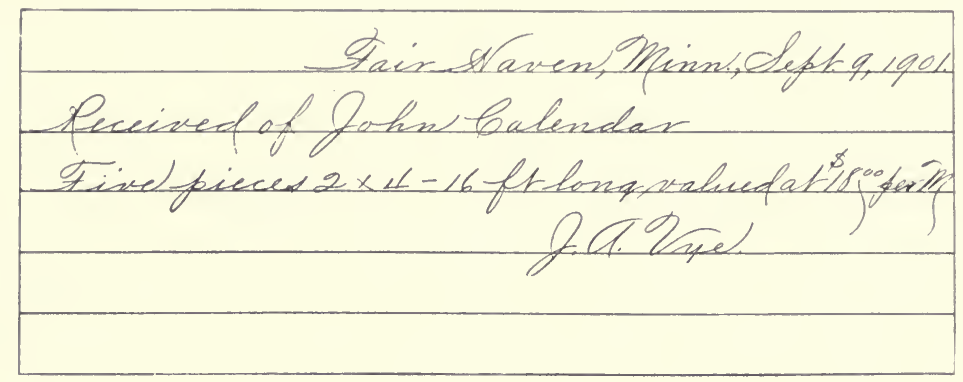

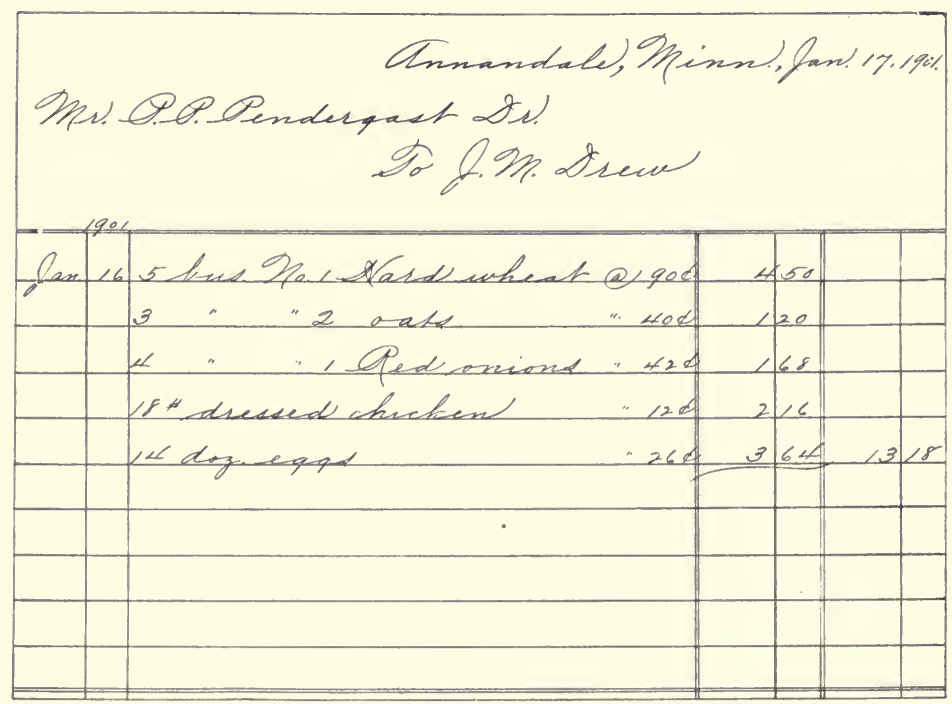

"Constant complaints never get pity." 



If you want to know what a ducat is worth, try to borrow one.-Sp., Proverb. 
time book shows that he has worked this month 3 days at the threshing rate of $\$ 2.00 ; 18 \frac{1}{2}$ days plowing at $\$ 1.25$; paid him by check in full.

\section{EDWARD BERRY.}

Ipril 14, 19(14 he begins season's work today at $\$ 22.00$ per month if he works only part of the season, and $\$ 27.00$ per month if he works the entire season; my account with him for previous time shows that I owe him $\$ 12.09 \ldots \ldots$ Apr. 18, I paid James Johnson on Berry's account \$1.00 . . . Apr. 20, paid him by check. $\$ 2.00 \ldots$. Apr. 23 , bought tobac(o) for him 50c.... Apr. 25, paid him by check \$1.55; bought jacket for him 50c....Apr. 27 , bought sox for him 50c... Apr. 30, my time book shows that he has worked this month $15 \frac{1}{2}$ days.... May 1, bought handkerchiefs for him $40 \mathrm{c} . .$. May 4, paid him by check $\$ 4.00 \ldots$. May 17 , sent check to Montgomery Ward \& Co., on Berry's account \$6.96; bought tobacco for him 10c... May 23, bought tobacco for him 10c ..... May 2S, bought tobacco for him 10c; gave him an order for trade at Olson's store, $\$ 1.00$.... May 30 , bought razor for him $\$ 1.50 \ldots$. May 31 , paid him by check $\$ 3.00$; paid postage on three letters for him 6ic; my time book shows that he has worked this month 26 days as per contract, and extra time painting $31-10$ days at $\$ 2.00 \ldots$. June 1 , Thomas Hammer asks me to allow Berry a credit of $\$ 3.50$ and charge to his account; Berry quit work today and I paid him by check in full.

\section{WILLIAM CONLEY.}

April 14, he begins season's work today at $\$ 20.00 \mathrm{per}^{\circ}$ month if he works only a part of the season and $\$ 25.00$ per month if he works the entire season; my account with him for previous time shows that I owe him $\$ 4.62 \ldots .$. Apr. 15. bought for him $\frac{1}{2}$ lb. tobacco 25 c.... Apr. 19 , bought for him 1 jal snuff 7 ร̌c; I paid James Johnson on Conley's account 
$\$ 1.00 \ldots$. ... 20, bought tobacco for him 25c...Apr. 25, bought tobacco for him $35 \mathrm{c}$; paid him by check $\$ 5.00 \ldots$ Apr. 30, my time book shows that he has worked this month 15 days....May 3 , bought jacket for him 75c....May 4 , bought tobaceo for him 50c.... May 7 , bought gloves for him $\$ 1.00$ .... May 12, bought tobacco for him 5c... May 13, gave him an order to trade at Olson's store, $\$ 1.50$.... May 16 , paid him by check $\$ 10.00$... May 17 , bought snuff for him $75 \mathrm{c} . .$. May 24 he requested me to pay $25 \mathrm{c}$ for him toward a baseball outfit for the men; my time book shows that he has worked this month $19 \frac{3}{4}$ days, discharged him for gambling on the farm, and paid him by check in full.

\section{BUSINESS ACCOUNT.}

A Business Account is one made for the purpose of determining the loss or gain on any given thing. The account is ruled according to the instructions given on page 1 . The thing under consideration is debited with whatever it costs, including its inventory value, and credited with whatever it returns, including its inventory value. The difference between the two sides is then a loss if the debit be the larger. and a gain if the credit be the larger.

\section{AN ACCOUNT WITH POULTRY.}

Jan. 1, 1904, I have on hand 175 chickens with an average value of $33 \mathrm{c} . . . J a n .6$, sold 6 dozen eggs at $22 \mathrm{c} \ldots$...Jan. 8 , used in house 5 dozen eggs at 20c....Jan. 11, sold 14 dozen and 5 eggs at $20 \mathrm{c} . .$. Jan. 14, sold 10 pounds dressed chicken at $7 \mathrm{c} . . . J a n .18$, sold 5 dozen eggs at 20c...Jan. 24, used

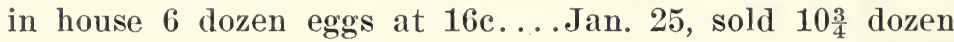
eggs at $16 \mathrm{c} . . . J a n .30$, used 3 dozen eggs at 16c. and 25 pounds dressed chicken at $7 \mathrm{c} . .$. Jan. 31, fed during month $11 \frac{1}{2}$ bushels corn at $65 \mathrm{c}, 5$ bushels oats at $50 \mathrm{c}$; spent 15 hours in care of chickens during month at $10 \mathrm{c}$; sold $6 \frac{3}{4}$ dozen eggs at $16 \mathrm{c} . .$. Feb. 7 , sold 11 dozen eggs at $16 \mathrm{c} . .$.

"Credit lost is like a broken looking glass." 


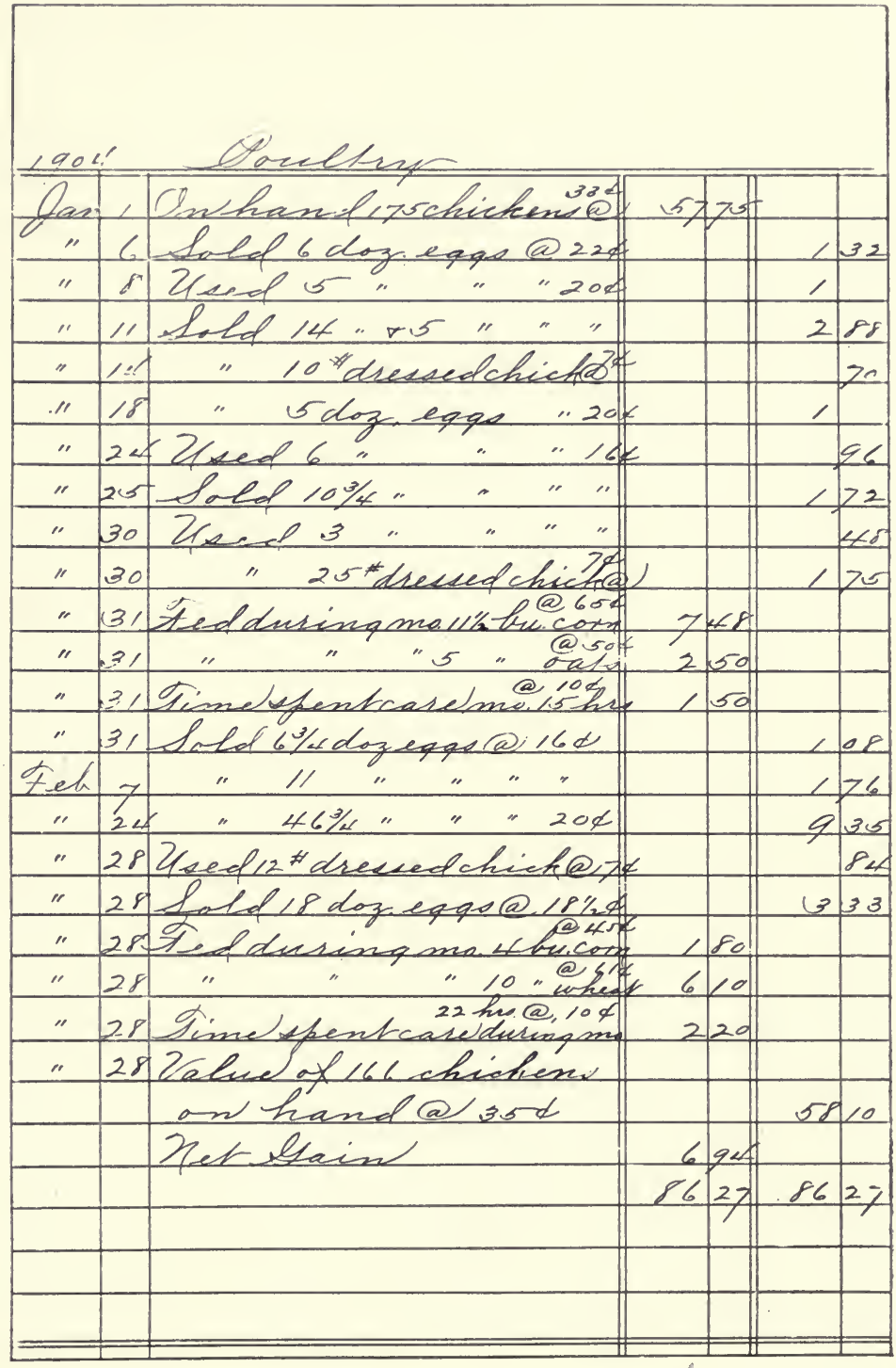

"Every fool is wise when he holds his tongue." 
Feb. 24, sold $46 \frac{3}{4}$ dozen eggs at $20 \mathrm{c} .$. . Feb. 28 , used in house 12 pounds dressed chicken at $7 \mathrm{c}$; sold 18 dozen eggs at $18 \frac{1}{2} \mathrm{c}$. Fed during month 4 bushels corn at $45 \mathrm{c}, 10$ bushels wheat at $61 \mathrm{c}$; spent 22 hours in care of chickens during month at $10 \mathrm{c}$; have on hand 166 chickens with an average value of $35 \mathrm{c}$.

\section{HOGS.}

Jan. 1, 1902, value of 15 hogs on hand $\$ 123 \ldots$...Jan. 31, fed during January coln and milk worth $\$ 14.50$; spent time in their care worth $80 \mathrm{c} . .$. Feb. 17, paid cash for lumber to build trough $90 \mathrm{c} . .$. Feb. 28 , fed during February corn and milk worth $\$ 25.20$; spent time in their care $\$ 1.29 \ldots$ Mar. 10, paid for six pigs, six weeks old, $\$ 30$; sold nine young hogs for $\$ 114.52$.... Mar. 18, killed hog for home use, weight $504 \mathrm{lbs}$., value $7 \frac{1}{2} \mathrm{c}$; have on hand to-day 11 head, valued $\$ 65$. Was the experience profitable?

\section{SHEEP.}

Jan. 1, 1904, value of 56 ewes and 56 lambs on hand $\$ 440.00$ ....Jan. 19, sold 53 lambs, \$235.78....Jan. 31, fed during month 28 bushels of corn at $38 \mathrm{c}, 48$ bushels of oats at $47 \mathrm{c}, \frac{1}{2}$ ton of hay at $\$ 4.00$; value of time spent in care of sheep during month, $\$ 3.65 . .$. Feb. 4 , paid for rock salt, $71 \mathrm{c} . .$. Feb. 28, fed during month $185-7$ bushels corn at 38c, 6 bushels and 20 pounds of oats at $48 \mathrm{c}$; value of time spent in care of sheep during month $\$ 2.30 \ldots$ Mar. 5, received for sheep pelt 50c....Mar. 31, fed during month 18 bushels corn at $40 \mathrm{c}, 20$ bushels oats at $26 \mathrm{c}$; value of time spent in care of sheep during month $\$ 1.90 \ldots$ Apr. 4, sold sheep pelt, 50c...A Apr. 29, paid for bran and shorts $\$ 1.75 \ldots$ Apr. 30 , fed during month 36 bushels of oats at 26c, 25 bushels of corn at $40 \mathrm{c}$; value of time spent in care of sheep during month $\$ 1.39 \ldots$ May 8 , received for 2 sheep pelts $\$ 1.20 \ldots$ May 20, paid for wool twine, $60 \mathrm{c}$.... May 22, paid for shear-

He that has lost his credit is dead to the world.-Ger. 
ing 52 sheep at $8 c \ldots$. May 31 , value of time spent in care of sheep during month $\$ 2 . \$ 4 \ldots$. June 6 th, received cash for 431 pounds wool at $16 \mathrm{c}$; paid for freight on wool sacks $25 c . .$. June 30 , value of time spent in care of sheep during month, 36c...July 30, paid cash for salt, 56c....Aug. 29, paid cash for 14 sheep $\$ 38.50$; value of one sheep killed for home use $\$ 2.50 \ldots$. Sept. 1 , paid for 18 sheep $\$ 50.00 \ldots$ Sept. 30, value of time spent in care of sheep during month 72c.... Oct. 17 , received for 5 sheep pelts $\$ 1.75 \ldots$. Oct. 21 , received cash for 74 sheep $\$ 257.80 \ldots$ Nor. 8, paid for 4 lambs $\$ 14.00 \ldots$ Nov. 30 , value of time spent in care of sheep during the last two months $\$ 2.75 \ldots$ Dec. 22 , received cash for 11 sheep $\$ 38.00 \ldots$ Dec. 30, paid cash for 23 sheep $\$ 95.00 \ldots$ Dec. 31 , value of corn storer fed to sheep since leaving pasture $\$ 96.00$, fed during this month 31 bushels corn at $30 \mathrm{c}$; value of time spent in care of sheep during month $\$ 1.82$; value of sheep on hand $\$ 322.00$.

\section{CATTLE.}

Jan. 1, 1904, value of cattle on hand $\$ 420.00 \ldots . . J a n .23$, paid for 1 ton of bran, $\$ 16.00$....Jan. 26, received cash for 138 gallons of milk at $10 \frac{1}{2} \mathrm{c} . . . . J a n .31$, used in the house during month 13 gallons of milk at $10 \frac{1}{2} \mathrm{c}$; paid for grinding feed $\$ 1.13$; value of grain and roughage fed during the month $\$ 32.18$; value of time spent in care of cattle $\$ 20.31 \ldots$ Feb. 6 , sold one cow $\$ 30.00 \ldots .$. Feb. 12, sold one cow $\$ 28.00$; bought one cow $\$ 30.00 \ldots$...Feb. 13, bought one cow $\$ 30.00$ ....Feb. 15, received cash for 126 gallons milk at $10 \frac{1}{2} \mathrm{c} . \ldots$ Feb. 16, paid for grinding feed 24c...Feb. 29, sold four calves $\$ 8.00$; value of grain and roughage fed during month $\$ 26.83$; value of labor spent in care of cattle during month $\$ 20.31 \ldots$. Mar. 2, sold two calves $\$ 2.00 \ldots$ Mar. 5, sold one calf $\$ 1.00 \ldots$ Mar. 10, received cash for 215 gallons of milk at $10 \frac{1}{2} \mathrm{c} \ldots$ Mar. 19, sold one cow $\$ 25.00 \ldots$ Mar. 28, received cash for 344 gallons of milk at $10 \frac{1}{2} \mathrm{c} . .$. Mar. 31, used in house during month, 4 gallons milk at $10 \frac{1}{2} \mathrm{c}$; value of

"Today's egg is better than tomorrow's hen." 
grain and roughage fed during month $\$ 32.14$; value of time spent in care of cattle during month $\$ 15.22 \ldots$ Apr. 4, sold 1 cow $\$ 25.00 \ldots$. Apr. 20, received cash for 394 gallons of milk at $10 \frac{1}{2} \mathrm{c} . .$. Apr. 30, used in house during month 15 gallons of milk at $10 \frac{1}{2} \mathrm{c}$; value of grain and roughage fed during month $\$ 28.00$; value of time spent in care of cattle, \$25.62...May 11, received cash for 702 gallons of milk at $10 \frac{1}{2} \mathrm{c} . .$. May 23 , sold one calf $\$ 1.00 \ldots$ May 31 , used in house during month 15.6 gallons of milk at $\mathrm{Sc}$; value of grain and roughage fed during month $\$ 18.50$; value of time spent in care of cattle during month $\$ 21.24 \ldots$. June 11, received cash for 915 gallons of milk at $8 \mathrm{c} . .$. June 17, sold one cow $\$ 20.00$; bought one cow and two calves $\$ 30.00$ ....June 30, used in house during month 23.7 gallons of milk at $8 \mathrm{c}$; received cash for 1159 gallons of milk at $\mathrm{Sc}$; value of pasture during month $\$ 14.00$; value of time spent in care of cattle during month $\$ 22.79 \ldots$ July 21 , received cash for 1161 gallons of milk at 8c....July 31, used in house during month $26 \frac{1}{2}$ gallons of milk at $8 \mathrm{c}$; value of pasture during month $\$ 14.00$; value of time spent in care of cattle during month $\$ 23.48 . \ldots$ Aug. 25 , received cash for 1002 gallons of milk at 8c....Aug. 31, used in house during month $24 \frac{1}{2}$ gallons of milk at Sc; value of pasture during month $\$ 15.00$; value of time spent in care of cattle during month $\$ 20.41$... . Sept. 2 , sold cow and calf $\$ 22.00 \ldots$. Sept. 22 , received cash for $\$ 83$ gallons of milk at Sc....Sept. 30 , used in the house during month 17 gallons milk at 8c; value of pasture during month $\$ 13.00$; value of time spent in care of cattle during month $\$ 19.62 \ldots$. Oct. 19 , received cash for 802 gallons of milk at $8 c$; used in the house to date 26 gallons of milk at $8 c \ldots$. Oct. 31 , value of pasture during month $\$ 13.00$; value of time spent in care of cattle during month $\$ 21.66 \ldots$ Nov. 19 , received cash for 661 gallons milk at Sc... Nov. 30, value of milk used in the house to date 16 gallons at $S c$; value of grain and roughage fed during month $\$ 15.20$; value of time spent in care of cattle

"Sins and debts are always more than we think them to be." 
during month $\$ 24.77 \ldots$ Dec. 31, received cash for 530 gallons of milk at $10 \mathrm{c}$; used in house during month $16 \frac{1}{4}$ gallons milk at $10 \mathrm{c}$; value of grain and roughage fed during month $\$ 35.39$; value of time spent in care of cattle during month $\$ 2.49$; paid for grinding feed $\$ 1.29$. Value of cattle on hand $\$ 450.00$.

\section{HOGS.}

Jan. 1, 1904, value of hogs on hand $\$ 280.00$; Red-dog flour on hand for hog feed 414 pounds at $\$ 1.10$ per hundred... Jan. 23, bought 250 pounds Red-dog flour at $\$ 1.10 \ldots$. Jan. 29 , bought 125 pounds Red-dog flour at $\$ 1.10 \ldots . . J a n .31$, paid for grinding feed $37 \mathrm{c}$; value of farm grains fed during month $\$ 27.42 \ldots$ value of time spent in care of hogs during month $\$ 3.07 . .$. Feb. 4, bought 125 pounds Red-dog flour at $95 \mathrm{c} . .$. Feb. 12 , bought 125 pounds Red-dog flour at $\$ 1.10$ ....Feb. 16, paid for grinding feed 4c...Feb. 29, value of farm grains fed during month $\$ 32$; value of time spent in care of hogs during month $\$ 2.84 \ldots$.... Mar. 8 , paid for grinding feed 36c....Mar. 31, value of farm grains fed during month $\$ 37.68$; value of time spent in care of hogs $\$ 2.54 \ldots$. Apr. 2, paid for grinding feed 15c....Apr. 6, bought 1 ton of oil meal at $\$ 28.80 \ldots . A$ pr. 13 , paid for grinding feed $30 \mathrm{c} . . . A$ pr. 1S, paid for grinding feed $30 \mathrm{c} . \ldots$ Apr. 25, sold 1 hog weighing 140 pounds at $6 \mathrm{c}$ per pound....Apr. 30, value of farm grains fed during month $\$ 22.93$, value of time spent in care of hogs during month $\$ 3.84 \ldots$ May 8 , sold 2 pigs $\$ 4.00 \ldots$ May 10 , sold 2 pigs $\$ 4.00 \ldots$ May 11 , paid for grinding feed $30 \mathrm{c} . .$. May 23 , paid for grinding feed $30 \mathrm{c} . .$. May 24, sold 1 pig $\$ 2.00 \ldots$ May 25 , sold one hog weighing 180 pounds at 6c... May 26, sold sow and pigs $\$ 10.00 \ldots$... May 31 , value of farm grains fed during month $\$ 19.24$; value of time spent in care of hogs during month $\$ 6.60 \ldots$. June 6 , paid for grinding feed $50 \mathrm{c} \ldots$...June 7 , sold sow and pigs $\$ 10.00 \ldots$ June 11 , paid for grinding feed $30 \mathrm{c}$ ....June 17, sold 23 fall pigs and 2 old hogs weighing "If a man deceive me once, shame on him; if he deceive me twice, shame on me." 
2354 pounds at $\$ 5.75$ per hundred....June 23 , paid for grinding feed $70 \mathrm{c} . . . J u n e$, value of farm grains fed during month $\$ 25.90$; value of time spent in care of hogs during month $\$ 8.06 \ldots . . . J u l y$ 9, paid for grinding feed $30 \mathrm{c}$ ....July 14, sold 2 pigs $\$ 4.00 \ldots$. July 18 , paid for grinding feed 55c...July 25 , paid for 1 ton middlings $\$ 20.00 \ldots$. July 30, paid for grinding feed $30 \mathrm{c} \ldots$...July 31 , value of farm grains fed during month $\$ 16.72$; value of time spent in care of hogs during month $\$ 6.59 \ldots$ Aug. 5, paid for grinding feed $30 \mathrm{c} . .$. Aug. 15, paid for grinding feed $20 \mathrm{c}$ ....Aug. 31, value of farm grains fed during month $\$ 20.39$; value of time spent in care of hogs $\$ 8.23 \ldots$... Sept. 3, paid for grinding feed $30 \mathrm{c} . .$. Sept. 13 , paid for grinding feed 20c... . Sept. 30, fed during month 1236 pounds barley at $34 \mathrm{c}$ per bushel; value of time spent in care of hogs during month $\$ 6.48$.... Oct. 20, paid for grinding feed $30 \mathrm{c} . .$. Oct. 22, sold hogs weighing 3100 pounds at $\$ 4.25 \ldots$. Oct. 27 , sold $1 \log \$ 8.75 \ldots$. Oct. 31, sold hogs weighing 1565 pounds at $\$ 4.40$; fed during month 720 pounds barley at 34c per bushel; "Hogged off" 14.2 acres of corn, on which the cost of seed and labor was $\$ 88.70$; value of time spent in care of hogs $\$ 3.30 \ldots$ Nov. 3, bought 5 hogs at $\$ 9.00$ each .... Nov. 10, paid for boar and freight on same $\$ 26.00 \ldots$ Nov. 11, paid for grinding feed 30c..... Nov. 15, sold hogs weighing 1,515 pounds at $\$ 4.33 \ldots$ Nov. 25 , sold 1 hog $\$ 5.00$ .... Nov. 29, sold hogs weighing $4,240 \mathrm{lbs}$. at $\$ 3.80 \ldots$ Nov. 30 , fed during month 720 pounds barley at $33 \mathrm{c}$ per bushel; "Hogged off" $2 \frac{1}{2}$ acres corn on which the cost of labor and seed was $\$ 32.50$; value of time spent in care of hogs during month $\$ 10.91 \ldots$ Dec. 23 , sold hogs weighing 1150 pounds at $\$ 3.75 \ldots$. . Dec. 31 , value of farm grains fed during month $\$ 5.66$; value of time spent in care of hogs during month $\$ 7.79$; killed for house use 1 hog weighing 250 pounds and valued when dressed 5c per pound. (The foregoing (harge for labor includes that of dressing this hog); value of logs on hand today $\$ 80.00$.

Tell everybody your business and the devil will do it for you.-Ttal. 


\section{CHAPTER II.}

\section{A COMPLETE SET OF ACCOUNTS FOR HIBBARD FARM.}

$A$ full and complete memorandum is given in the following pages covering all sales and purchases, feeds fed to live stock, and application of labor on Hibbard Farm, Northfield, Minnesota, from January 1, to June 30, 1904. Comprehensirely this memorandum may be said to include all the business activities of the farm and family for six months.

The memoranda for the month of January are used to illustrate the principles of firm accounting on the ledger and auxiliary cards. The accounts used in the order of their occurrence are F. C. Hibbard, Real Estate, Cassh, Horses, Cattle, Hogs. Poultry. Machinery and Implements, Oats, Barley, Corn, Hay, House Furnishings, Clothing. Food and Fuel, Family Expense, Farm Expense, Mercantile Co., Ground Feed, Mrs. Greason, Crescent Creamery Co., School District No. 78, Mrs. Sherpy, Mrs. Dunlap, Loss and (iain, Balance.

\section{HOW TO TAKE AN INVENTORY.}

An inventory is a list of property values. On the farm an inventory is usually made for two general purposes: First, to have accurate data with which to open or close the farm books of accounts; second, to check up on the different kinds of property so that the farmer may ascertain whether the articles are being lost or not, and whether he has enough of certain articles to last through seasons of particular necessity. But the value of inventories is not at all limited to the generally recognized uses. They are particularly important in the adjustment of insurance. and the settlement of estates.

Beware of little expenses, a small leak will sink a ship.-Franklin. 
In taking an inventory for the first time, some difficulty will be experienced. Items will be omitted which should be included. A general farm carries so many enterprises, and when fully equipped there are so many different tools, utensils, and supplies, that some precautions should be taken to avoid missing anything. If an inventory is not accurate it will be quite impossible to determine the profitableness of the different enterprises.

As a rule the most convenient method of taking inventory on the farm is to use a pocket memorandum book and lead pencil. Write at the top of several pages the natural headings or classifications, somewhat as follows: Head the first page, Real Estate; the second, Horses; the third, Cattle; and so on, using as many headings as are thought convenient. Then beginning work at some place, for instance the barn, make an entry in the book on the appropriate page, of each item and its value, taking care to include everything. When all articles in the barn have been properly listed, go to some other place, and so from place to place until every kind of property is listed. When the work is finished, every classification should be carefully examined and if anything has been omitted it should be put in at this time.

The pencil entries should then be copied in neat form as a permanent record. This may be done in a book used for that purpose, or on separate sheets of paper to be filed, or on statement cards-if a card system of bookkeeping is followed.

In all the work of taking inventory and making it into a permanent record, the scheme of classification suggested is of the utmost importance. In some things the subdivision should be quite extensive. For instance, it will be found helpful to subdivide the heading of tools into graden tools, blacksmith tools, carpenter tools and haying tools. In House Furnishings, greater accuracy will be obtained if the division is made somewhat as follows:

Blame is the lazy man's wages.-Dan. 
Stoves, store-furniture, dishes, kitchen furniture, parlor furniture, bed-room furniture, carpets, pictures, musical instruments, books and bed-clothing. Other subheadings which seem essential may be used. If this scheme of subdivision be followed it will save many errors, for careful classification is an aid to the memory. If anything has been left out in making the first list it is quite apt to be noticed when making an examination preparatory to drawing the final copy.

\section{ESTIMATING THE QUANTITY.}

Because it is often impracticable to weigh large quantities of small grains and roughage, it is necessary to resort to the measure of bins, piles and mows to determine their contents. For small grains the general rule is that the number of bushels is equal to the number of cubic feet multiplied by eight-tenths. Where the grain is of standard weight, the result obtained by this multiplication is slightly too small and should be corrected by adding to it one-third of a bushel for every one hundred cubic feet.

For corn on the cob in good condition, allow two and onefourth cubic feet to the bushel.

It should be borne in mind that there is a wide variation between a standard bushel of 2150.42 cubic inches and an ordinary bushel basket full.

In measuring circular bins, the surface of the bottom is obtained by multiplying the square of the diameter by the decimal .7854.

Hay in stack or mow, after settling for several months, gives a ton to every 430 to 450 cubic feet, according to quality and condition. In the following inventory 450 cubic feet are called a ton. The cubic feet in each bin except the circular ones are computed by multiplying together the dimensions in fect expressed fractionally. The bushels in each bin are ascertained by multiplying the cubic feet correct to hundredths by eight (.8) tenths, and adding onethird of a bushel for every one hundred cubic feet.

Borrowing is the mother of trouble.-Hebrew. 


\section{CHAPTER III.}

\section{RECORDING THE INVENTORY.}

Take two statement cards and figure out and record the inventory of January 1, 1904. Use card 34 as a model but never copy from it. Solutions of each example involved should be submitted to your teacher. The cards should be kept as a permanent record for upon these facts is based our ability to determine the prosperity or adversity of the business.

\section{HIBBARD FARIM.}

Inventory of real and personal property, Jan. 1, 1904.

Real Estate: SE $\frac{1}{4}$ Section 4, Township 111, Range 19, 160 acres at $\$ 60$ per acre.

Cash: On hand $\$ 49.82$.

Horses: Topsy, black mare 6 years old $\$ 100$; Kitty, black mare 6 years old $\$ 100$; Nell, gray mare 14 years ol $\$ \$ 125$; Bill, gray gelding 16 years old $\$ 75$; Maude, brown mare 2 years old $\$ 40$; Jess, brown mare 1 year old $\$ 20$.

Cattle: Cows-Nell, grade shorthorn 2 years old $\$ 30$; Black and White Heifer, grade shorthorn 2 years old $\$ 25$; Red Heifer, grade shorthorn 2 years old $\$ 25$; Crossy, grade shorthorn 6 years old $\$ 30$; Whitey, grade shorthorn 10 years old $\$ 25$; Durham, grade shorthorn 8 years old $\$ 30$; Black and White Cow, Jersey shorthorn 8 years old $\$ 25$; Dot, grade shorthorn 1.0 years old $\$ 30$; Star, grade shorthorn 7 years old $\$ 25$; Bangs, grade shorthorn 2 years old $\$ 25$; Holstein, grade Holstein 6 years old $\$ 22$.

It is hard to pay for bread that has been eaten.-Dan. 
Yearling Heifers - Daisy, grade shorthorn $\$ 10$; Belle, grade shorthorn $\$ 18$; Bess, grade Holstein $\$ 10$.

Fattening Cattle--2 red and white steers, one white heifer 2 years old, 1 bull old and lame $\$ 135$.

Bull-Jack, grade shorthorn 1 year old $\$ 20$.

Calves-Five $\$ 40$.

Hogs: 3 brood sows at $\$ 15 ; 8$ hogs weighing about 250 lbs. each, 2,000 lbs. at $\$ 4.30 ; 7 \operatorname{logs}$ weigling about $200 \mathrm{lbs}$. each, 1,400 lbs. at $\$ 4.30$.

Poultry: Ninety chickens at $33 \frac{1}{3} \mathrm{c}$.

Machinery and Implements: Vehicles--1 lumber wagon $\$ 25 ; 1$ old lumber wagon $\$ 5 ; 1$ two-seated road wagon $\$ 45$; 1 surrey \$5.5; 1 old one-horse buggy \$5; 1 pair light bobs $\$ 10 ; 1$ cutter $\$ 15$.

Machinery-1 binder $\$ 15 ; 1$ mower $\$ 18 ; 1$ hay rake $\$ 3$; 1 seeder $\$ 28 ; 1$ fanning mill $\$ 20 ; 1$ corn sheller $\$ 5 ; 1$ cream separator $\$ 40$; hay fork and rope $\$ 6.50 ; 1$ grindstone $75 \mathrm{c}$.

Implements - 1 sulky plow $\$ 35 ; 2$ old walking plows $\$ 5$; 1 spring-tooth harrow $\$ 7 ; 1$ old wood-frame harrow $\$ 3 ; 1$ disk $\$ 10 ; 1$ two-horse cultivator $\$ 20 ; 1$ old two-horse cultivator $\$ 4$; 1 one-horse cultivator $\$ 2$.

Tools-Forks \$1.25; 1 scoop shovel 75c; small tools $\$ 1.50$; hoes and rakes 50c; 1 set barn scales $\$ S$.

Horse Equipment-1 double harness $\$ 20 ; 1$ old double harness $\$ 5$; 1 light double harness $\$ 25$; blankets $\$ 3$.

0ats: Market value $31 \mathrm{c}$ per bushel. Storage ticket No. 9362 of Farmers' Elevator Co. for 924 bu. 25 lbs.; 1,784 lbs. in feed boxes at barn; 470 lbs. ground and in sacks.

*Bin Measurements-No. 1-16 ft. 6 in. by $12 \mathrm{ft} .10 \mathrm{in.} \mathrm{by}$ $5 \mathrm{ft} .10 \mathrm{in}$; No. $2-12 \mathrm{ft} .6$ in by $8 \mathrm{ft} .10$ in. by $2 \mathrm{ft} .6$ in.; No. 3-10 ft. $10 \mathrm{in.} \mathrm{by} 5 \mathrm{ft} .8$ in. by $2 \mathrm{ft}$; No. $4-3 \mathrm{ft} .6 \mathrm{in}$. by 2 ft. 6 in. by 2 ft. 9 in.; No. $5-12$ ft. 6 in. by $6 \mathrm{ft}$. by $3 \mathrm{ft}$. 7 in.; No. 6-11 ft. by $6 \mathrm{ft}$. by $4 \mathrm{ft} .10 \mathrm{in.}$

*See estimating the quantity, page 29.

"Doing nothing is another way of doing wrong." 
Barley: Market value $35 \mathrm{c}$ per bushel. 248 bu. machine measure, of which $672 \mathrm{lbs}$. have been ground and are in sacks.

Corn: Market value fodder $\$ 3$ per ton, corn on ear 35c per bushel.

Corn Fodder-Whole and shredded 20,405 lbs.

$\dagger$ Ear Corn Bin Measurements: No. 1-19 ft. 6 in. by $7 \mathrm{ft} .3$ in. by $6 \mathrm{ft}$; No. 2 - 5 ft. by 5 ft. by $1 \mathrm{ft}$; No. 3 -Round bin, $8 \mathrm{ft}$. in diameter by $4 \mathrm{ft}$. deep. No. 4 -Round bin $8 \mathrm{ft}$. in diameter by $3 \mathrm{ft}$. deep.

\$Hay: Market value $\$ 6$ per ton. Mow No. $1-28 \mathrm{ft}$. by $30 \mathrm{ft}$. by $18 \mathrm{ft}$; Mow No. 2-28 ft. by $30 \mathrm{ft}$. by $8 \mathrm{ft} .7 \mathrm{in}$.

House Furnishings: 2 kitchen ranges $\$ 30 ; 2$ tables, 1 for kitchen and 1 for dining-room $\$ 10 ; 9$ dining-room chairs $\$ 15 ; 4$ rocking chairs $\$ 7 ; 6$ kitchen chairs $\$ 2 ; 1$ large upholstered chair $\$ 5 ; 2$ small upholstered chairs $\$ 5 ; 1$ bedroom suite $\$ 15 ; 2$ bedroom suites $\$ 20 ; 1$ bedroom suite $\$ 5$; carpets $\$ 30$; bedding $\$ 50 ; 2$ couches $\$ 5 ; 1$ cot $\$ 1 ; 1$ parlor table $\$ 2 ; 1$ sideboard $\$ 15 ; 1$ wardrobe $\$ 50 ; 1$ secretary $\$ 15 ; 1$ secretary $\$ 5 ; 1$ clock $\$ 4 ; 1$ piano $\$ 150 ;$ kitchen utensils and stoveware $\$ 5$; dishes $\$ 25$; refrigerator $\$ 15$; churn $\$ 2$.

Clothing: Men's clothing, $\$ 50$; women's clothing, $\$ 75$.

Food and Fuel: Food-Sundry groceries, $\$ 7.25 ; 72$ quarts canned fruit at $20 \mathrm{c} ; 25$ bu. potatoes at $75 \mathrm{c}$.

Fuel-Market value of coal $\$ 7.25$ per ton; dry and green wood $\$ 4$ per cord. 2,760 lbs. coal; 4 cords dry wood; 4 cords green wood.

There are no unpaid bills or obligations standing against the proprietor.

†\$\$\$See estimating the quantity, page 29 .

"Just try to be yourself. It may tire you, but try it." 

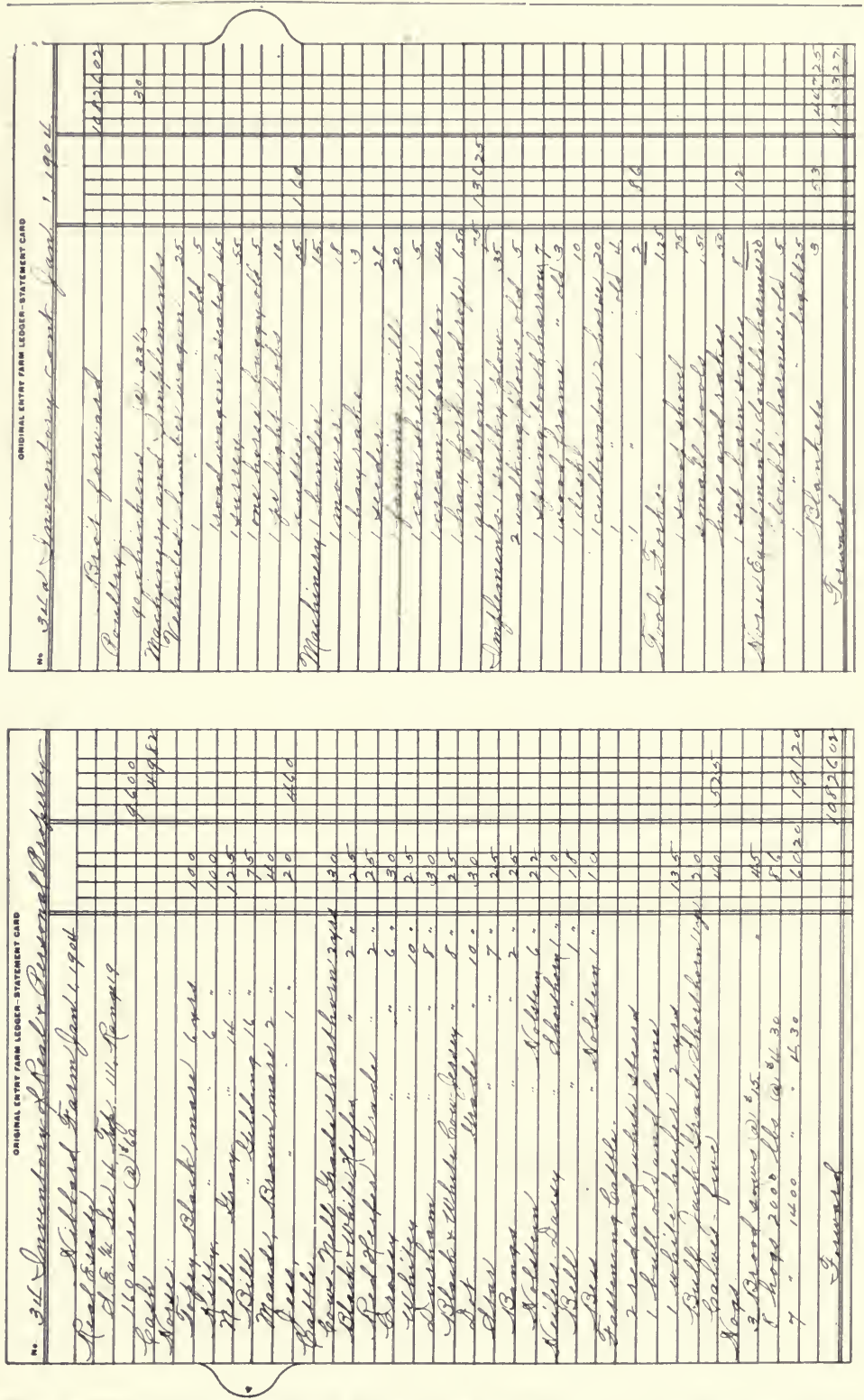

The pathway to success lies in serving others, not in affronting them. -Hubbard. 

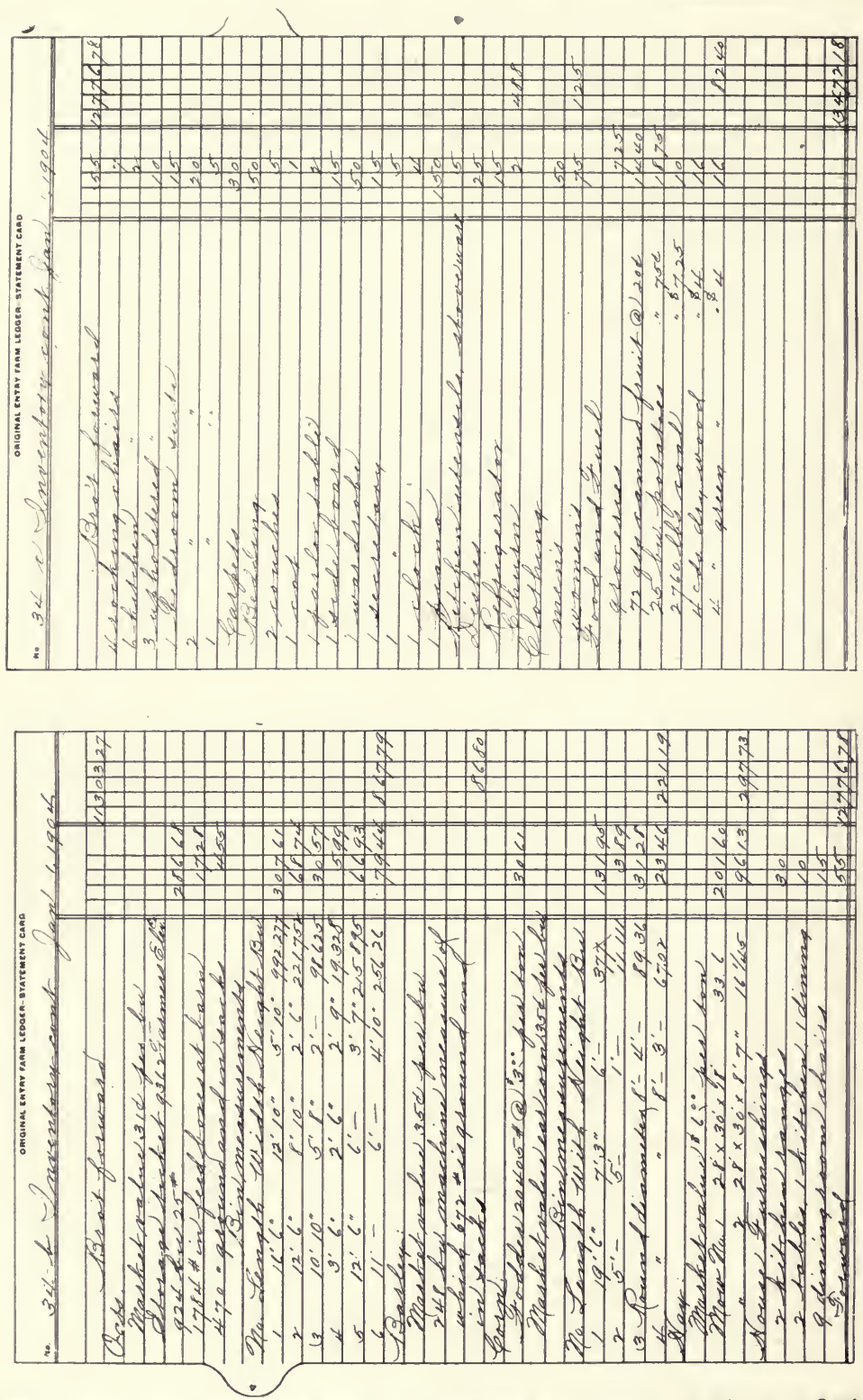

The ideas that benefit a man are seldom welcomed by him on first presentation.-Hubbard. 


\section{CHAPTER IV.}

\section{COMPLETE BUSINESS RECORD.}

The student has now learned that cash is debited when it is received; that it is credited when it is paid out or passes from cash.

That a person is debited when he receives something of value without at the time paying for it; that he is credited when he gives something of value without at the time re. ceiving an equivalent.

That an account with things such as Hogs, Poultry, Sheep, and Cattle, is debited with its original cost (Inventory) and all other costs; that it is credited with whatever it brings into the business and finally with its present value (Inventory); that an excess of the debit would then show a loss and that an excess of the credit would show a gain.

Having learned these things thoroughly he is now ready to take up the more complex matter of considering at one time the two sides of a transaction. Every business transaction has two sides, a debit and a credit. Double entry bookkeeping considers both of these sides. It thus produces an equality of debits and credits; that is, after a transaction has been entered there are as many dollars and cents on the debit side of the ledger card as on the credit side. For example: If you were to receive cash $\$ 50.00$, it would have to come from some source. Cash must be debited. Something must be credited. Credit the source from which it came. If it was received from a man because he owed you, credit him. If you sold him a cow and the cash was in payment, credit Cattle or such an account

\footnotetext{
"Our troubles are the result of our own weakness."
} 
as the cow was classed under. If from the sale of poultry, credit Poultry. There must be as many dollars and cents credited as there are debited. But of course this credit need not necessarily be placed under one account. It may be distributed under different ones. Likewise the debit side of a transaction may be distributed under several accounta, but the sum of these debits must equal the sum of the rredits.

In all the transactions of the memoranda which follow there must be made debits and credits of equal amount.

\section{LEDGER TITLES.*}

The name of the enterprise, firm or individual with whom a ledger account is kept should be written at the head of the account. Names used in such a manner are called ledger titles.

In a complete set of double entry accounts for any business, there are usually three kinds of ledger titles used. First, Proprietary, under which is kept a record of the transactions of the proprietor or proprietors as individuals with the business. Second, Business, under which is kept a record of transactions involving enterprises capable of experiencing either a gain or a loss. Third, Financial, under which is kept a record of transactions with cash, and with persons and firms whose dealings are on account. The number of ledger titles used in any set of accounts will depend first, on the number of proprietors of the business; second, on the number of enterprises carried on and the amount of detailed information desired concerning the profitableness of the enterprises; third, on the number of persons and firms with whom accounts are kept.

The number of proprietary accounts is usually small, more often one than more. The number of financial accounts is determined by the conditions which influence the manager of the business to extend or refuse credit to those with whom he deals. The number of business ac-

*See page 27.

Many a man's reputation would not know his character if they met. -Hubbard. 
counts is determined arbitrarily by the manager for the purpose of securing those details of information as to cost of production and relative profit which will help him to plan and execute his business intelligently, and thus realize the most substantial profit.

\section{DEBIT WHAT COMES IN.-CREDIT WHAT GOES OUT.}

After having determined upon the titles* for the ledger cards (names of accounts to be used) the inventory should be recorded under the ones to which it belongs. It thus comes in to these accounts and is debited (cards 2, 3, 4, 5, $6,7,8,9,10,11,12,13,14$, and 15). The total of these debits is $\$ 13,472.18$ as exhibited on card $34 \mathrm{c}$. The proprietor or owner, F. C. Hibbard, gives out or distributes these values to the several accounts and he should be credited with the sum of them (card 1 ).

It will be noted from an examination of the entries of inventories, made on the cards, that the date, year, month, and day of month-are always given, the year being placed first at the head of the column. The name under "Opposite Title" is that of the account receiving the opposing entry debit or credit as the case may be. Under "Explanation" the details are given, or a reference telling where the details may be found. The "Posted to No." column contains the card number of the account mentioned in the "Opposite Title" column, and by this means the opposite account may be readily found.

After faithfully posting (carrying the records to the ledger cards) the inventory, the transaction beginning with Jan. 1st should be posted to card 15, Food and Fuel debited and Cash credited card 3. Hours of labor should be recorded on card 31. The titles at the left are those receiving the benefit of the labor. Team time, card 31a; milk, butter and cream used and sold, card 32; eggs laid, used and sold, card 32a; Jan. 5th, feed fed, card 33 "Feeding Statement Card"; milk produced, card 36, 36a and $36 \mathrm{~b}$ should all be recorded.

\footnotetext{
*See page 27.
}

Talk less and listen more.-Hubbard. 


\section{CHAPTER V.}

\section{HIBBARD FARM.}

Daily memoranda showing business transactions, disposition of labor, feeds consumed by live stock, dairy and poultry products, and other facts bearing on the business of the farm and family. (All transactions not specified on account are for cash.)

Jan. 1.-Bought celery 20c.... Hours of labor: Cattle $4 \frac{1}{2}$; horses 2 ; $\operatorname{hogs} \frac{3}{4}$; poultry $\frac{1}{3}$; hauling coal, 1 man and team 2; 1 man $\frac{1}{2}$ (Charge Food \& Fuel, man time $2 \frac{1}{2}$ hours; team time 2 hours).... Eggs laid 8... Set aside for home use:* 1 gallon milk, 1 pint cream.

Jan. 2.-Paid subscription to Northfield News to Jan. 1, 1905, \$1 (Charge Family Expense); repair of shoes 40c; book for farm accounts 25c (Charge Farm Expense); medicine 90c (Charge Family Expense); scrubbing soap $75 \mathrm{c}$ (Charge Food \& Fuel) ... . Sold $2 \frac{1}{2}$ quarts of cream at $20 \mathrm{c} . .$. Hours of labor: Cattle $4 \frac{1}{2}$; horses 2 ; $\log s \frac{3}{4}$; poultry $\frac{1}{3} \ldots$ Eggs laid 9.... Set aside for lıome use: 1 gallon milk, 1 pint cream.

Jan. 3.- Sold to Mercantile Co. on account, 10 lbs. butter at $22 \mathrm{c}$... . Bought of Mercantile Co. on account, 5 lbs. butter at 23c (This butter was part of the $10 \mathrm{lbs}$. sold above and was purchased baek to sell to Mrs. Sherpy, a regular customer, who found herself entively out); 2 dozen oranges at 35c.... Sold 5 lbs. butter at 22c....Hours of labor: Cattle $4 \frac{1}{2}$; horses 2; hogs $\frac{3}{4}$; poultry $\frac{1}{3} \ldots$ Eggs laid 9 .... Set aside for home use : 1 gallon milk, 1 pint cream, 5 eggs.

*One pint equals one pound.

Art is the beautiful way of doing things.-Hubbard. 
Jan. 4.-Hours of labor: Cattle $4 \frac{1}{2}$; horses 2 ; hogs $\frac{3}{4}$; poultry $\frac{1}{3}$..... Eggs laid 6 .... Set aside for home use: 1 gallon milk, 1 pint cream.

Jan. 5.-Hours of labor: Cattle $4 \frac{1}{2}$; horses 2; hogs $\frac{3}{4}$; poultry $\frac{1}{3} \ldots$ Eggs laid $10 \ldots$... Set aside for home use : 1 gallon milk, 1 pint cream.

†Weight of feeds fed to live stock to-day: Cattle-Milch cows 60 lbs. ground feed; fattening cattle $45 \mathrm{lbs}$. ground feed; calves 60 lbs. skim milk; all cattle 128 lbs. hay, 136 lbs. shredded and 141 lbs. unshredded corn fodder;.... horses-121 lbs. hay, 45 lbs. oats, 10 lbs. corn on cob;... hogs-139 lbs. corn on cob and all skim milk and buttermilk not otherwise used; $; . . . p o u l t r y-9$ lbs. corn on cob and $10 \mathrm{lbs}$. oats.

The weight of milk given by each cow morning and evening to-day was as follows: Red Heifer, morning 7.1 lbs., evening 7.5 lbs.; Nell, morning 12 lbs., evening 11.8 lbs.; Black and White Heifer, morning 5.2 lbs., evening 5.4 lbs.; Crossy, morning 11.3 lbs., evening 11.6 lbs.; Whitey, morning 8 lbs., evening 8.5 lbs.; Black and White Cow, morning 8.8 lbs., evening 9 lbs.; Durham, morning 9 lbs., evening 9.5 lbs.; Dot, morning 14 lbs., evening 14.9 lbs.; Star, morning 6 lbs., evening 5.2 lbs.

*'Took sample of each cow's milk at both milkings to-day for composite test.

Jan. 6.-Bought of Mercantile Co. on account, 5 yds. cotton cloth at $13 \mathrm{c} . .$. Paid for medicine $30 \mathrm{c}$; repairing shoes $15 \mathrm{c}$; barber $10 \mathrm{c}$ (Charge medicine and barber to Family Expense)... Gave Mrs. Hibbard to purchase clothing $\$ 2 . .$.

fOn the 5th. 15th and 25 th of each month the quantity of feed fed was ascertained by actual weight and recorded on Card 33 - Feeding Statement. Fairly good results might be obtained by weighing once a month.

$\$$ Page 65, Card 35d. Not recorded on Card 33 until end of month.

* A composite test of milk consists of taking a certain amount as: a sample each milking or each day, and putting these samples together into a bottle and keeping them until a test is desired at the end of a week or month, as the case may be. Then a sample from this mixture is taken and tested, and is considered an average test for the period. To keep these samples in condition to be tested a little potassium bichromate is usually put into the bottle before the first sample is put in.

"Help yourself by helping others." 
Sold 1 gallon cream at $80 \mathrm{c} . .$. Hours of labor: Cattle $4 \frac{1}{2}$; horses 2 ; $\operatorname{hogs} \frac{3}{4}$; poultry $\frac{1}{3}$; hauling manure to corn land 1 man and team 3 (Charge Corn); hauling coal 1 man and team 3 (Charge Food \& Fuel).... Eggs laid 8.... Set aside for home use: 1 gallon milk, 1 pint cream, 4 eggs.

Jan. 7.-Bought flowers for Degree of Honor 10c (Charge Family Expense)....Hours of labor: Cattle $4 \frac{1}{2}$; horses 2; hogs $\frac{3}{4}$; poultry $\frac{1}{3}$; hauling manure to corn land 1 man and team $2 \frac{1}{2}, 1$ man $\frac{3}{4}$; hauling coal 1 man and team $3 \ldots$ Eggs laid 7 .... Set aside for home use: 1 gallon milk, 1 pint cream, 5 pounds butter.

Jan. 8.-Paid church on subscription $\$ 7.50$; school tuition $\$ 5$ (Charge church subseription and school tuition to Family Expense); overcoat $\$ 18$.... Sold 2 dozen eggs at $26 \mathrm{c} ; 8 \frac{1}{2}$ quarts cream at 20c (Purchaser lacked 2 cents of having enough to pay in full)....Hours of labor: Cattle $4 \frac{1}{2}$; horses 2 ; $\operatorname{logs} \frac{3}{4} ;$ poultry $\frac{1}{3} \ldots$.. Eggs laid $8 \ldots$. . Set aside for home use: 1 gallon milk, 1 pint cream.

Jan. 9.-Sold 5 lbs. butter at 22c.... Hours of labor : Cattle $4 \frac{1}{2}$; horses 2 ; hogs $\frac{3}{4}$; ponltry $\frac{1}{3} \ldots$ Eggs laid $8 \ldots$... Set aside for home use: 1 gallon milk, 1 pint cream, 6 eggs.

Jan. 10.-Hours of labor: Cattle $4 \frac{1}{2}$; horses 2 ; hogs $\frac{3}{4}$; poultry $\frac{1}{3} \ldots$ Eggs laid $7 \ldots$.... Set aside for home use: 1 gallon milk, 1 pint creàm.

Jan. 11.-Hours of labor: Cattle $4 \frac{1}{2}$; horses 2 ; hogs $\frac{3}{4}$; poultry $\frac{1}{3}$.....Sacking *grist (for feed) 2 men $1 \frac{1}{2}$; cutting wood 1 man 1 ; repairing windmill 2 men 2 (Charge to Real Estate)....Eggs laid 10... Set aside for home use: 1 gallon milk, 1 pint cream, 6 eggs.

Jan. 12.-Paid for repairing pump $\$ 1.50$ (Charge to Real Estate); corn sheller 10c; feed grinding 60c; 5 gallons kerosene $90 \mathrm{c} \ldots$...Bought of Mercantile Co. on account, thread $10 \mathrm{c}$; spices $30 \mathrm{c} . .$. Sold $5 \mathrm{lbs}$. butter at $22 \mathrm{c}$; 5 lbs. butter at $23 \mathrm{c} ; 4 \frac{1}{2}$ quarts cream at $20 \mathrm{c} . .$. Sold Mercantile Co. on

*A grist is a term often applied to a quantity of grain taken to mill to be ground.

“To analyze another's failures, is to pave your own road to success." 
account, 5 lbs. butter at $22 \mathrm{c} . .$. Gave J. Riddell 10 lbs. butter (As this uas a gift, it should be charged to the Family Expense account at the rate of $22 \mathrm{c}$ per pound)....Hours of labor: Cattle $4 \frac{1}{2}$; horses 2 ; $\log s \frac{3}{4}$; poultry $\frac{1}{3}$; hauling grist for feed 1 man and team 3 (Charge to Ground Feed) †... Eggs laid 11.... Set aside for home use: 1 gallon milk, 1 pint cream.

Jan. 13.-Hours of labor: Cattle $4 \frac{1}{2}$; horses 2 ; hogs $\frac{3}{4}$; poultry $\frac{1}{3}$; sacking oats for market 1 man 1 (Charge Oats) ....Eggs laid 9.... Set aside for home use: 1 gallon milk, 1 pint cream.

Jan. 14.-Sold 3 dozen eggs at 22c; 87 bushels and $1 \mathrm{lb}$. oats at $32 c . .$. Hours of labor: Cattle $4 \frac{1}{2}$; horses 2 ; $\operatorname{logs} \frac{3}{4}$; poultry $\frac{1}{3}$; marketing oats 1 man and team 3,1 man $1 . .$. Eggs laid 7....Set aside for home use: 1 gallon milk, 1 pint cream, 5 lbs. butter.

Jan. 15.-Hours of labor: Cattle $4 \frac{1}{2}$; horses 2 ; hogs $\frac{3}{4}$; poultry $\frac{1}{3}$; marketing oats 1 man and team 3,1 man 1 ; hauling manure to corn land 2 men and team $1 \frac{1}{2} \ldots$ Eggs laid $13: \ldots$ Set aside for home use: 1 gallon milk, 1 pint cream.

Weight of feeds fed to live stock to-day: Cattle-Shred. ded corn fodder 134 lbs., unshredded corn fodder 140 lbs.. hay $131 \mathrm{lbs}$.; ground feed to milch cows $60 \mathrm{lbs}$.; ground feed to fattening cattle $46 \mathrm{lbs}$; skim milk to calves $60 \mathrm{lbs} . ; .$. horses-Hay 119 lbs., oats 45 lbs., corn on cob 11 lbs.;... hogs-Corn on cob 141 lbs., all skim milk and butter milk not otherwise used;....Poultry-Corn on cob 11 lbs., oats $10 \mathrm{lbs}$.

The weight of milk given by each cow at the morning and evening milking to-day was as follows: Red Heifer. morning 7 lbs., evening 6.9 lbs.; Nell, morning 11.9 lbs.. evening 12.3 lbs.; Black and White Heifer, morning 5.3, even ing 5 lbs.; Crossy, morning 11.2 lbs., evening 11.4 lbs.;

†Ground feed is made by taking six sacks (470 lbs.) of oats, and six sacks ( $672 \mathrm{lbs}$.) of barley to mill and grinding them together at a cost for grinding of 5c. per sack.

Religion is for show; Christianity is for wear.', 
Whitey, morning 8.8 lbs., evening $8.5 \mathrm{lbs}$.; Black and White Cow, morning 9.1 lbs., evening 8.9 lbs.; Durham, morning $9.3 \mathrm{lbs}$, evening $9.8 \mathrm{lbs}$; Dot, morning $14.8 \mathrm{lbs}$., evening 15 lbs.; Star, morning 5.4 lbs.; evening 5.5 lbs.

Took sample of each cow's milk at both milkings to-day for composite test.

Jan. 16.-Sold $2 \frac{1}{2}$ doz. eggs at $21 \mathrm{c} ; 178$ bu. 25 lbs. oats at $33 \mathrm{c} ; 8 \frac{3}{4}$ qts. cream at $20 \mathrm{c} . .$. Bought coffee and berries S5̌c; flour 50c... Bought of Mercantile Co. on account, groceries $\$ 1.30 \ldots$ Hours of labor: Cattle $4 \frac{1}{2}$; horses 2 ; hogs $\frac{3}{4}$; poultry $\frac{1}{3}$; marketing oats 1 man and team 3 , 1 man $1 \ldots$ Eggs laid $9 \ldots$... Set aside for home use: 1 gal. lon milk, 1 pint cream, 3 eggs.

Jan. 17.-Hours of labor: Cattle $4 \frac{1}{2}$; horses 2 ; hogs $\frac{3}{4}$; poultry $\frac{1}{3} \ldots$ Eggs laid $10 \ldots$.... Set aside for home use: 1 gallon milk, 1 pint cream, 5 eggs.

Jan. 18.-Hours of labor: Cattle $4 \frac{1}{2}$; horses 2; hogs $\frac{3}{4}$; poultry $\frac{1}{3}$; cutting wood 1 man 1 ; sacking grist for feed 2 men 1 ; sacking oats for market 2 men $\frac{1}{2}$... Eggs laid $11 \ldots$ Set aside for home use: 1 gallon milk, 1 pint creaṇ, 1 egg.

Jan. 19.-Paid coal bill rendered to-day $\$ 15.65$. . . Bought ledger 50c (Charge to Farm Expense); medicine 35̃c; overshoes $\$ 1.50$. . . Gave Mrs. Hibbard to purchase clothing $\$ 10$. ... Bo't 100 lbs. oil meal for cattle $\$ 1.50$. . . Bought of Mercantile Co. on account, 1 gallon lierosene $16 \mathrm{c}$; syrup $50 \mathrm{c}$; raisins 50c; 2 lbs. currants at $10 \mathrm{c}$; chocolate $20 \mathrm{c}$; pins $5 \mathrm{c}$; chimney 10c; bluing $15 \mathrm{c}$ (Charge the pins and bluing to Family Expense Account)... . Sold to butcher 1 heifer and 1 bull $\$ 42.50 ; 5 \mathrm{lbs}$. butter at $20 \mathrm{c} . .$. Sold on account, to Mercantile Co., $15 \frac{1}{4}$ lbs. butter at 22c, $3 \frac{1}{2}$ dozen eggs at 21c; to Mrs. Greason, 5 lbs. butter at 20c...Hours of labor: Cattle $4 \frac{1}{2}$; horses 2 ; $\operatorname{logs} \frac{3}{4}$; poultry $\frac{1}{3} \ldots$ Eggs laid $9 \ldots$. Set aside for home use: 1 gallon milk, 1 pint cream.

Jan. 20.-Hours of labor: Cattle $4 \frac{1}{2}$; marketing bull and heifer sold yesterday 1 man and team 6 ; horses 2 ; hogs $\frac{3}{4}$; poultry $\frac{1}{3} \ldots$... Eggs laid $6 \ldots$. Set aside for home use: 1 gallon milk, 1 pint cream, 6 eggs. 
Jan. 21.-Hours of labor: Cattle $4 \frac{1}{2}$; horses 2 ; hogs $\frac{3}{4}$; poultry $\frac{1}{3}$.... Eggs laid 9... Set aside for home use: 1 gallon milk, 1 pint cream, 5 pounds butter.

Jan. 22.-Paid for syrup 47c; medicine $\$ 1$; Grinding feed $60 \mathrm{c} . .$. Sold $25 \mathrm{lbs}$. butter at $20 \mathrm{c} ; 925$ bu. oats at $34 \mathrm{c} . .$. Hours of labor: Cattle $4 \frac{1}{2}$; horses 2 ; hogs $\frac{3}{4}$; poultry $\frac{1}{3}$; cutting wood 1 man $\frac{1}{2}$; hauling grist 1 man and team $4 \ldots$ Eggs laid 5.... Set aside for home use: 1 gallon milk, 1 pint cream, 3 eggs.

Jan. 23.-Sold 1 quart cream at 20c.... Hours of labor: Cattle $4 \frac{1}{2}$; horses 2 ; hogs $\frac{3}{4} ;$ poultry $\frac{1}{3} \ldots$ Eggs laid $5 \ldots$. Set aside for home use: 1 gallon milk, 1 pint cream, 6 eggs.

Jan. 24.-Hours of labor: Cattle $4 \frac{1}{2}$; horses 2; hogs $\frac{3}{4}$; poultry $\frac{1}{3} \ldots$ Eggs laid $6 \ldots$.... Set aside for home use: 1 gallon milk, 1 pint cream.

Jan. 25. - Paid A. O. U. W. assessment and dues $\$ 3$ (Charge Family Expense).... Delivered to Crescent Creamery Co. three five-gallon cans nearly full of cream, to be paid for on their test for butter fat, estimated for the purpose of this charge 14 gallons at $60 \mathrm{c} . .$. Bought sugar $\$ 1$; toilet soap 25̃ (Charge Family Expense); stationery for business correspondence 20c (Charge to Farm Expense)....Hours of labor: Cattle chores $4 \frac{1}{2}$; hauling cream 1 man and team 2; horses 2 ; hogs $\frac{3}{4}$; poultry $\frac{1}{3}$....Eggs laid 8 .... Set aside for home use: 1 gallon milk, 1 pint cream.

Weight of feeds fed to live stock to-day: Cattle-Shredded corn fodder 135 lbs., unshredded corn fodder 139 lbs., hay $131 \mathrm{lbs}$. ; ground feed to milch cows $60 \mathrm{lbs}$.; ground feed to fattening cattle $47 \mathrm{lbs}$; skim milk to calves $60 \mathrm{lbs} . ; . .$. horses-Hay 120 lbs., oats 45 lbs., corn on cob $10 \frac{1}{2}$ lbs.;... hogs-Corn on cob 140 lbs., all skim milk and buttermilk not otherwise used;....Poultry-Corn on cob 10 lbs., oats $10 \mathrm{lbs}$.

Weighed the milk of each cow at both milkings to-day, with the following results: Red Heifer, morning 6.8 lbs., evening 7.6 ; Nell, morning 12.4 lbs., evening 12.5 lbs.; Black

"The world is not against you. It is too busy." 
and White Heifer, morning 5.1 lbs., evening 5.5 lbs.; Crossy, morning 10.9 lbs., evening 10.5 lbs.; Whitey, morning 8.6 lbs., evening 8.6 lbs.; Black and White Cow, morning 9.2 lbs., evening 8.4 lbs.; Durham, morning 9 lbs., evening 9.4 lbs.; Dot, morning 15.3 lbs., evening 15.2 lbs.; Star, morning $6 \mathrm{lbs}$., evening $5.4 \mathrm{lbs}$.

Took samples of each cow's milk at both milkings to-day for composite test.

Jan. 26.-Paid for weighing oats 10c; meat 18c....Hours of labor: Cattle $4 \frac{1}{2}$; horses 2 ; hogs $\frac{3}{4}$; poultry $\frac{1}{3}$; marketing oats 1 man and team 3,2 men $\frac{1}{2} \ldots$ Eggs laid $6 \ldots$.... Set aside for home use: 1 gallon milk, 1 pint cream, 8 eggs.

A test was made to-day of the composite samples of each cow's milk taken on the 5th, 15 th and 25 th of the month. This test shows the per cent. of butterfat contained in each cow's milk, as follows: Red Heifer 3.8; Nell 4; Black and White Heifer 3.9 ; Crossy 3.5; Whitey 3.8; Black and White Cow 4.2; Durham 3.7; Dot 4; Star 4.2.

A *test of to-day's cream shows 27 per cent butter fat.

Jan. 27.-Bought of the Mercantile Co. on account, 1 gallon kerosene for School District No. 78, 16c; 1 gallon kerosene for home use $16 \mathrm{c} . .$. Hours of labor: Cattle $4 \frac{1}{2}$; horses 2 ; hogs $\frac{3}{4}$; poultry $\frac{1}{3}$; hauling ice 1 man and team 5 , 2 men 1 (Charge to Farm Expense)....Eggs laid 5.... Set aside for home use: 1 gallon milk, 1 pint cream.

Jan. 28.-Hours of labor: Cattle $4 \frac{1}{2}$; horses 2 ; hogs $\frac{3}{4}$; poultry $\frac{1}{3}$; hauling ice 1 man and team 5, 2 men 1 .... Eggs laid 3.... Set aside for home use: 1 gallon milk, 1 pint cream, 5 pounds butter.

Jan. 29.- Sold $3 \frac{1}{2}$ dozen eggs 80c.... Hours of labor. Cattle $4 \frac{1}{2}$; horses 2 ; hogs $\frac{3}{4}$; poultry $\frac{1}{3}$; hauling ice 1 man and team 5, 2 men 1.... Eggs laid $4 \ldots$. Set aside for home use: 1 gallon milk, 1 pint cream.

Jan. 30.-Paid for barbering $35 \mathrm{c}$; medicine $50 \mathrm{c}$; soap $50 \mathrm{c}$; cutting ice $\$ 3.60 ; 5$ gallons kerosene at $20 \mathrm{c} . .$. Sold 4 qts.

* Record on Herd Record Card.

"To know yourself as you are, is to turn your face toward success.", 
cream at $20 \mathrm{c} . .$. Sold on account, to Mrs. Sherpy $5 \mathrm{lbs}$. butter at $20 \mathrm{c}$; to Mrs. Dunlap 2 qts. cream at $20 \mathrm{c} . .$. Hours of labor: Cattle $4 \frac{1}{2}$; horses 2 ; hogs $\frac{3}{4}$; poultry $\frac{1}{3}$; hauling ice 1 man and team 3,2 men $\frac{1}{2}$; sacking oats for market 2 men $\frac{1}{2}$....Eggs laid 5.... Set aside for home use: 1 gallon milk, 1 pint cream.

Jan. 31.-Hours of labor: Cattle $4 \frac{1}{2}$; horses 2 ; hogs $\frac{3}{4}$; poultry $\frac{1}{3}$.... Eggs laid $3 \ldots$... Set aside for home use: 1 gallon milk, 1 pint cream, 5 eggs. 


\section{CHAPTER VI.}

\section{OPEN LEDGER.}

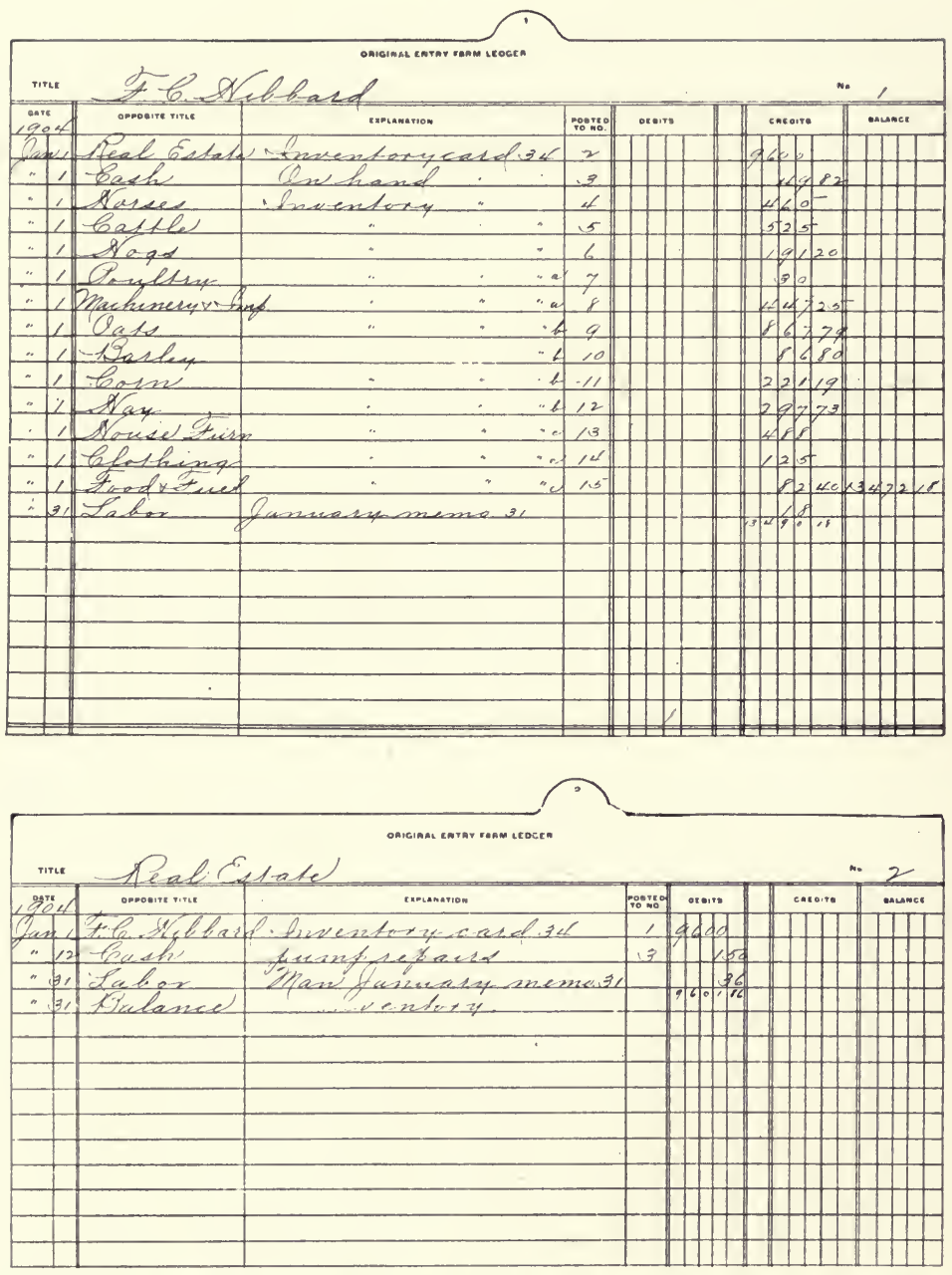

If there is any drudgery in our work we make it as we go along.Hubbard. 


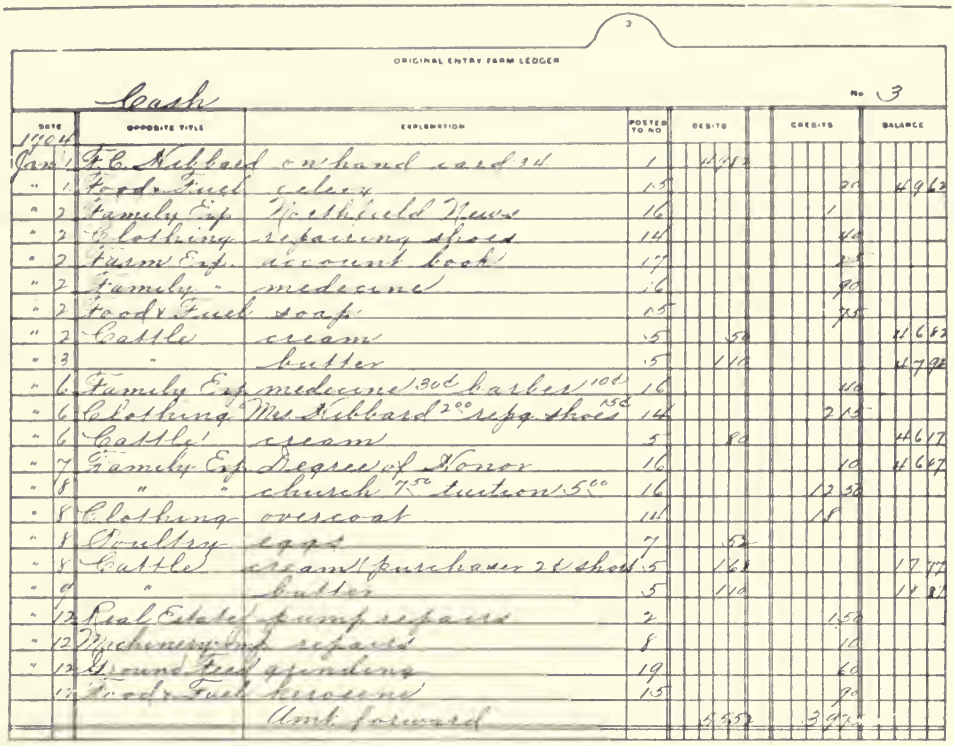

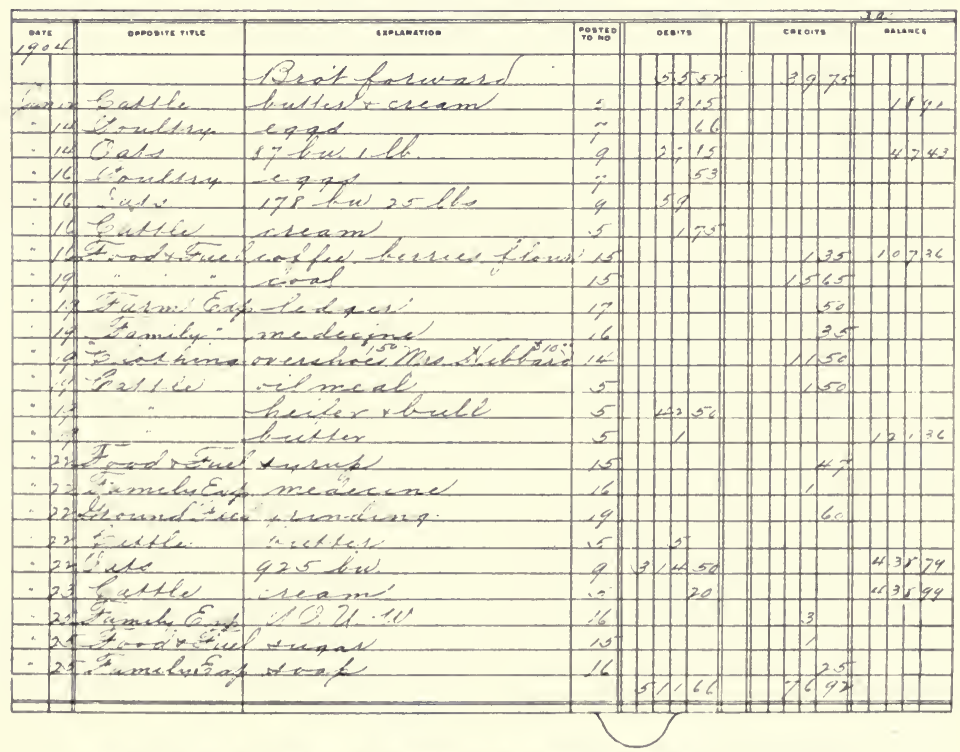

Who is rich? .He that rejoices in his portion.-Franklin. 


\begin{tabular}{|c|c|c|c|c|c|c|c|c|}
\hline and & omosites tirke. & enseamarion & 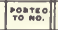 & \multicolumn{2}{|l|}{ Deterts } & \multicolumn{2}{|c|}{ enterese } & monece \\
\hline & & $B_{1}+t$ formen of & & & 66 & & & \\
\hline fas & Tutwest & Hadconery & 17 & & 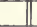 & & & \\
\hline . & Vate & ueiquherige & 9 & & - & & ect & \\
\hline$\therefore$ & Thadx $x$ & f.mencal & sit & & & & $\angle A$ & $11=426$ \\
\hline  & genelsy & $-x_{4}$ & 7 & 11 & ref & & & $4=506$ \\
\hline n & tramily tof & holler mederew &  & $H$ & & H & $\therefore=$ & 10 \\
\hline 3. & $\sin +f_{x}=$ & bhusaced & 15 & & & & $6 \mathrm{sen}$ & \\
\hline 30 & fouthles & chesend & 5 & & r, & & & \\
\hline & & & & & 26 & & उनी & \\
\hline & & & & & & & & \\
\hline & & & & & & & & \\
\hline & & & & & & & & \\
\hline & & & & & & $H$ & & \\
\hline & & & & & & & & \\
\hline & & & & & & & & \\
\hline & & & & & & & & \\
\hline & & & & & & & & \\
\hline & & & & & & & & \\
\hline & & & & & & H & & \\
\hline & & & & & & & & \\
\hline & & & & & & & & \\
\hline
\end{tabular}

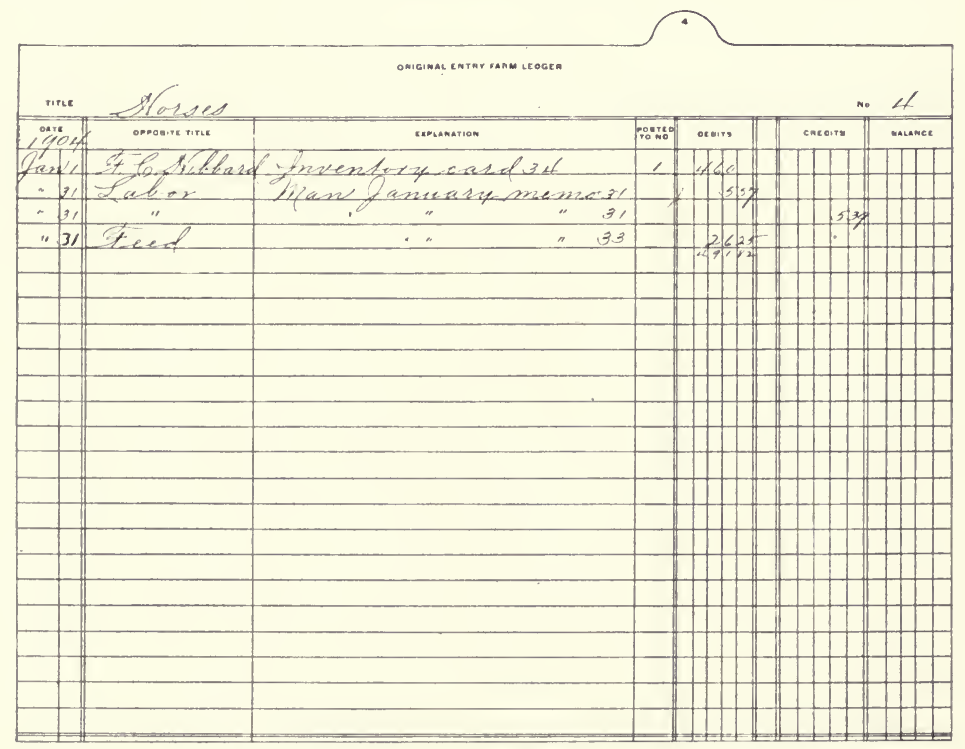

Who is strong? He that can conquer his bad habits.-Franklin. 




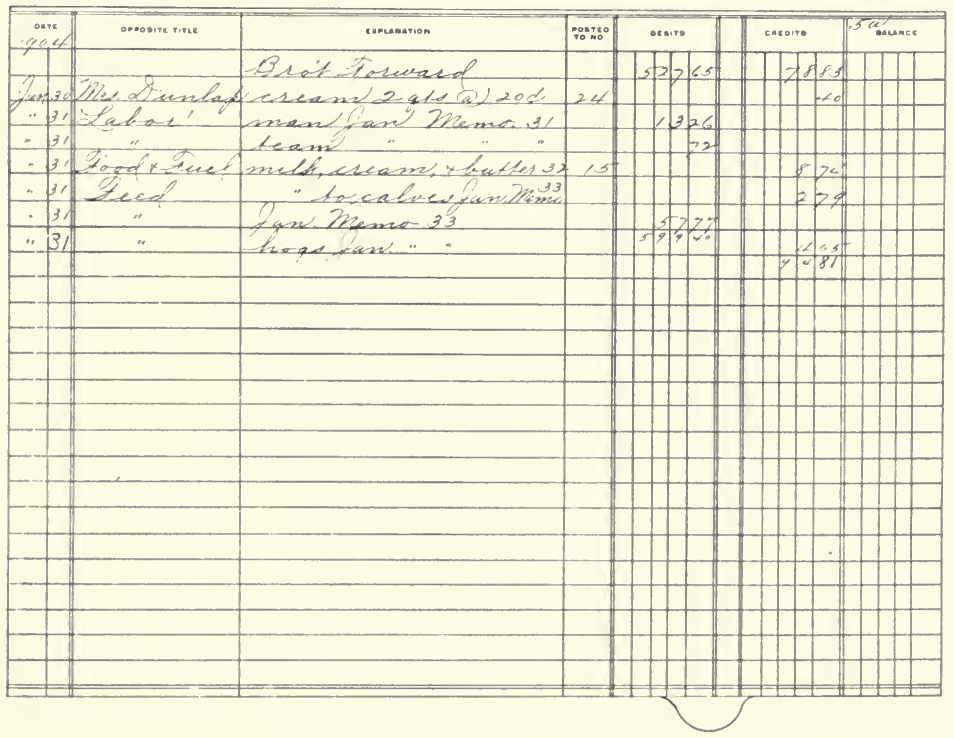

Make haste slowly.-Franklin. 
FARM ACCOUNTS.

\begin{tabular}{|c|c|c|c|c|c|c|}
\hline me & $4+001$ & Omianal entwr rosam laosen & & & & 6 \\
\hline oants & orpovire wine & comountion & 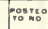 & oces: & cheors & ounct \\
\hline & El sublin: & 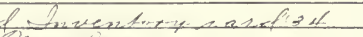 & 1 & & & \\
\hline & Laflari & 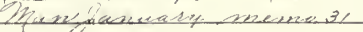 & & (b. & & \\
\hline$y^{3}$ & teced & $12 \ldots .33$ & & $2+5$ & 1 & \\
\hline & & & & & & \\
\hline & & & & & & \\
\hline & & & & & & \\
\hline & & & & & & \\
\hline & & & & & & \\
\hline & & & & & & \\
\hline & & & & & & \\
\hline & & 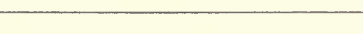 & & & & \\
\hline & & & & & & \\
\hline & & & & & & \\
\hline & & & & & & \\
\hline & & & & & & \\
\hline & & & & & & \\
\hline & & & & & & \\
\hline & & & & & & \\
\hline & & & & & & \\
\hline & & & & & & \\
\hline
\end{tabular}

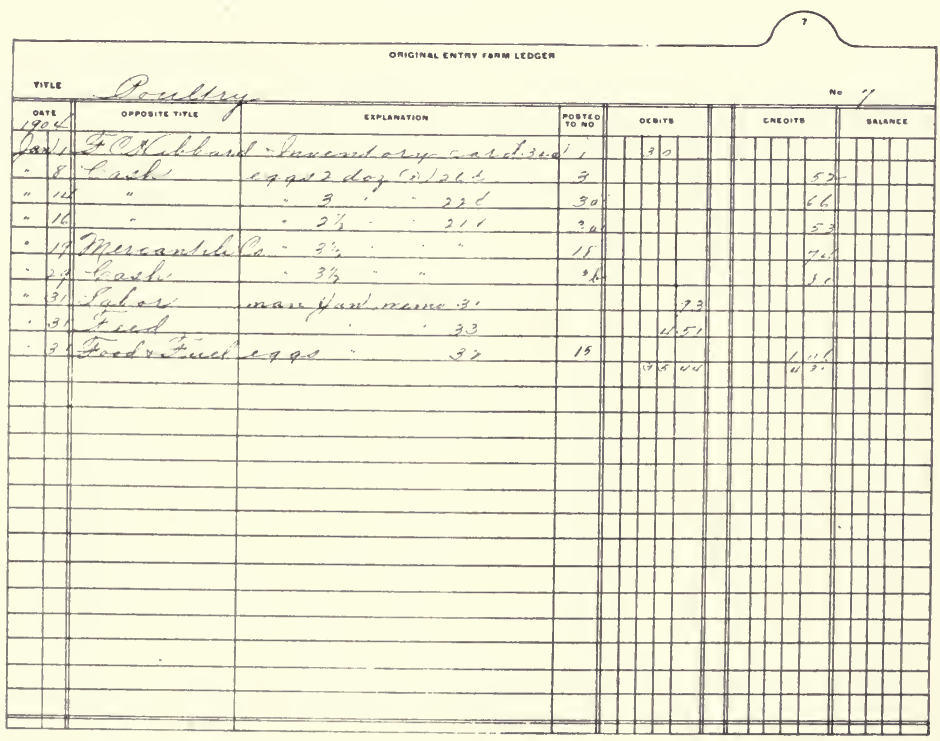

Be not too hasty to outbid another.-Franklin. 


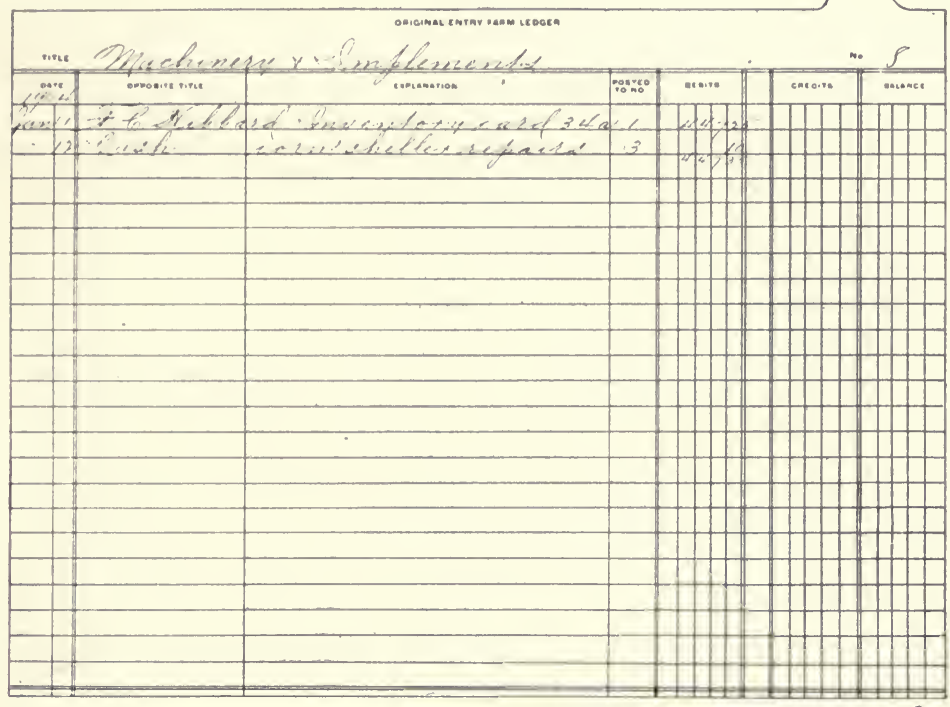

\begin{tabular}{|c|c|c|c|c|c|c|}
\hline rime & Cox & 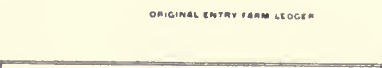 & & & & 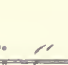 \\
\hline ane, & onoosine tritse & camcosention & on:"10 & oren: & casoorts & sacunce \\
\hline & tem riblea & 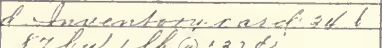 & $\frac{1}{2}$ & & & \\
\hline-16 & . & $178 \cdot 25 \cdots \cdot 330$ & $3 n$ & & 819 & \\
\hline & .. & $6 / 2.5^{-} \cdots \quad 3211$ & 3,4 & & 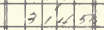 & \\
\hline & & Fucighinge & 3if & & & \\
\hline$\cdot 3-1$ & Taken & Zpant Lanuaxy-aneme z1 & & & & \\
\hline & $\operatorname{lin}_{1}$ & deagne "31 & & & t & \\
\hline & tised & 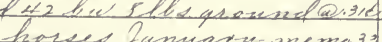 & 99 & & 1.1. & \\
\hline-31 & . & Hewllizt" & & & 3. & \\
\hline & & & & & il & \\
\hline & & & & & & \\
\hline & & & & & & \\
\hline & & & & & & \\
\hline & & & & & & \\
\hline & & & & & & \\
\hline & & & & & & \\
\hline & & & & & & \\
\hline & & & & & 1 & \\
\hline & & & & & & \\
\hline & & & & & & \\
\hline & $=$ & & & & 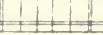 & \\
\hline
\end{tabular}



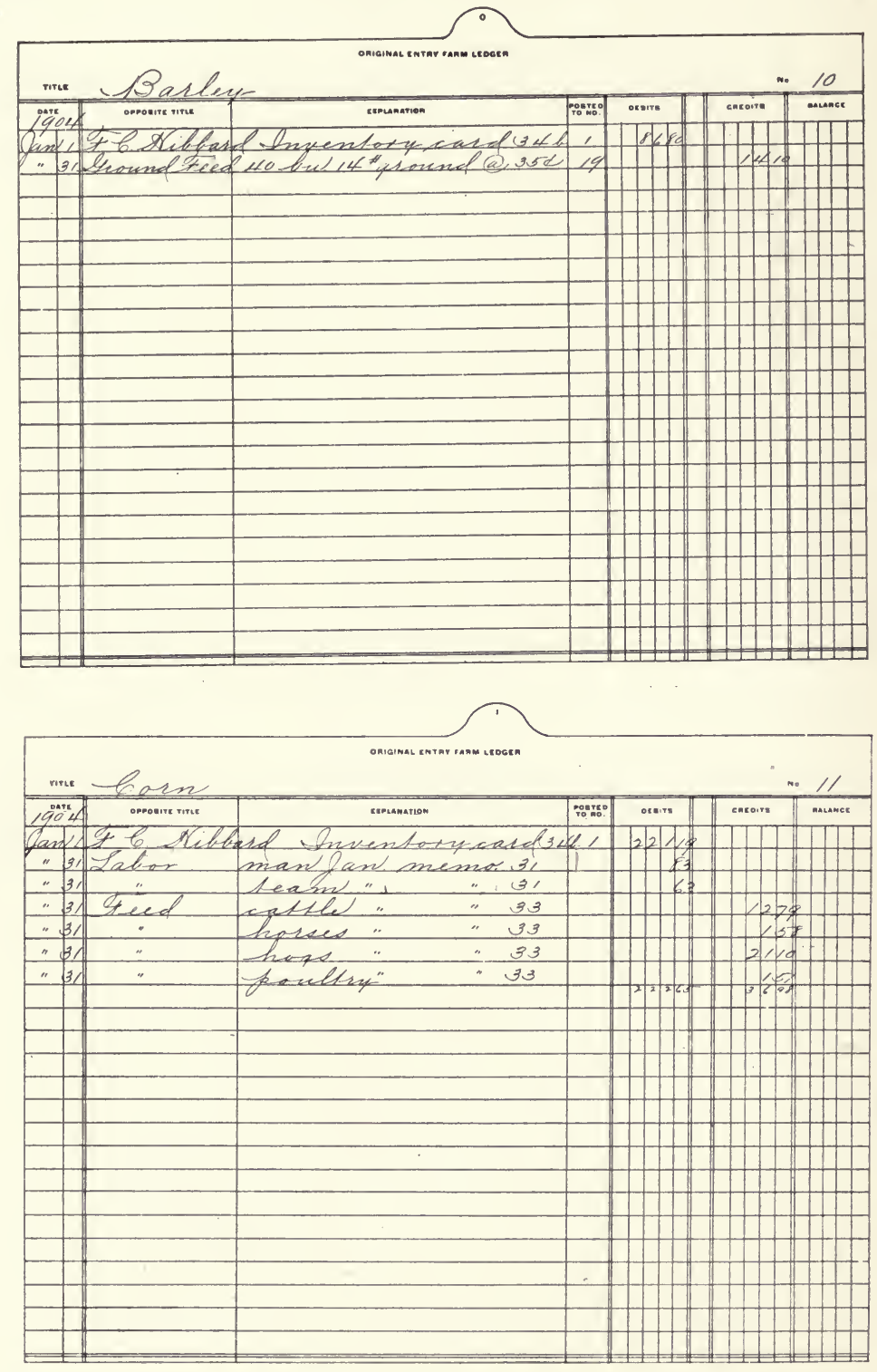

Despatch is the soul of business.-Chesterfield. 


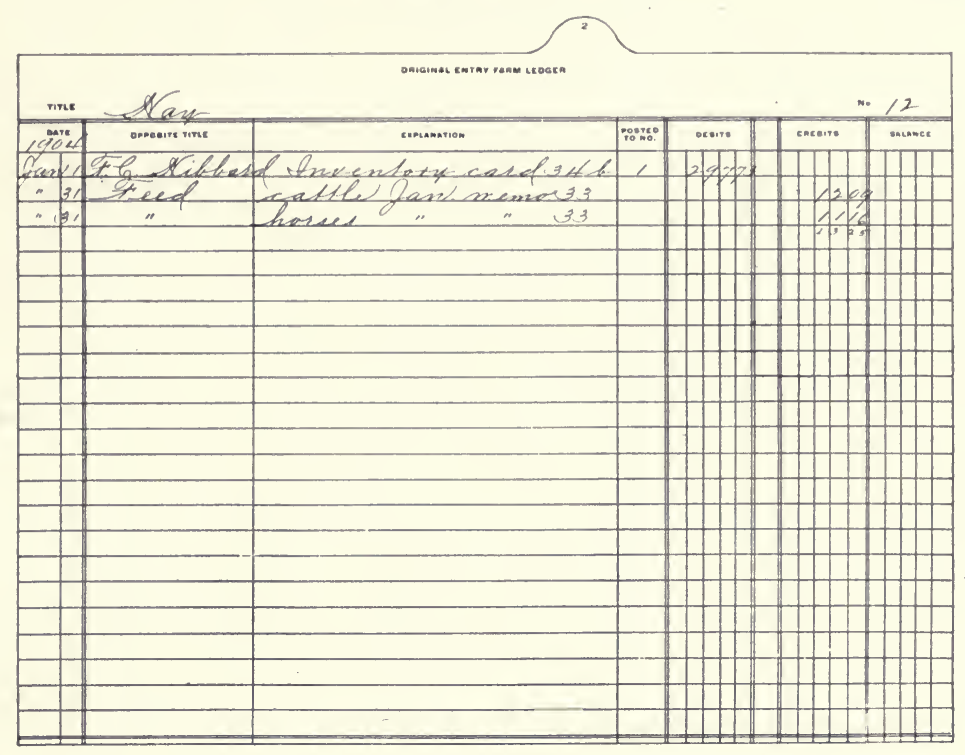

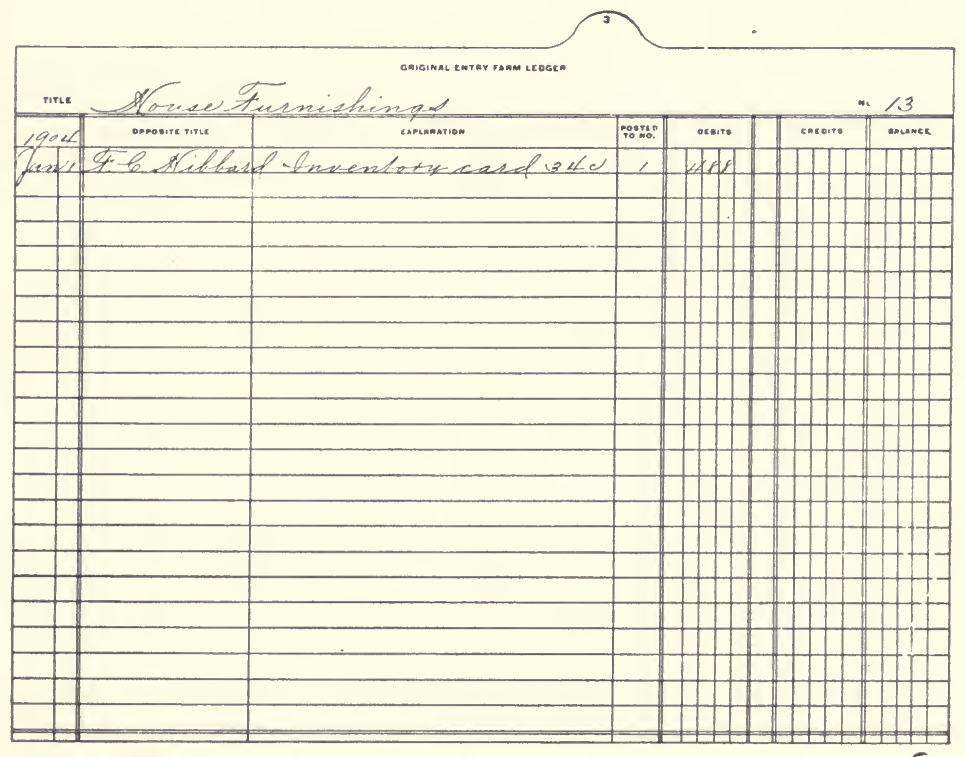

"Character, like a kettle, once mended always wants mending." 


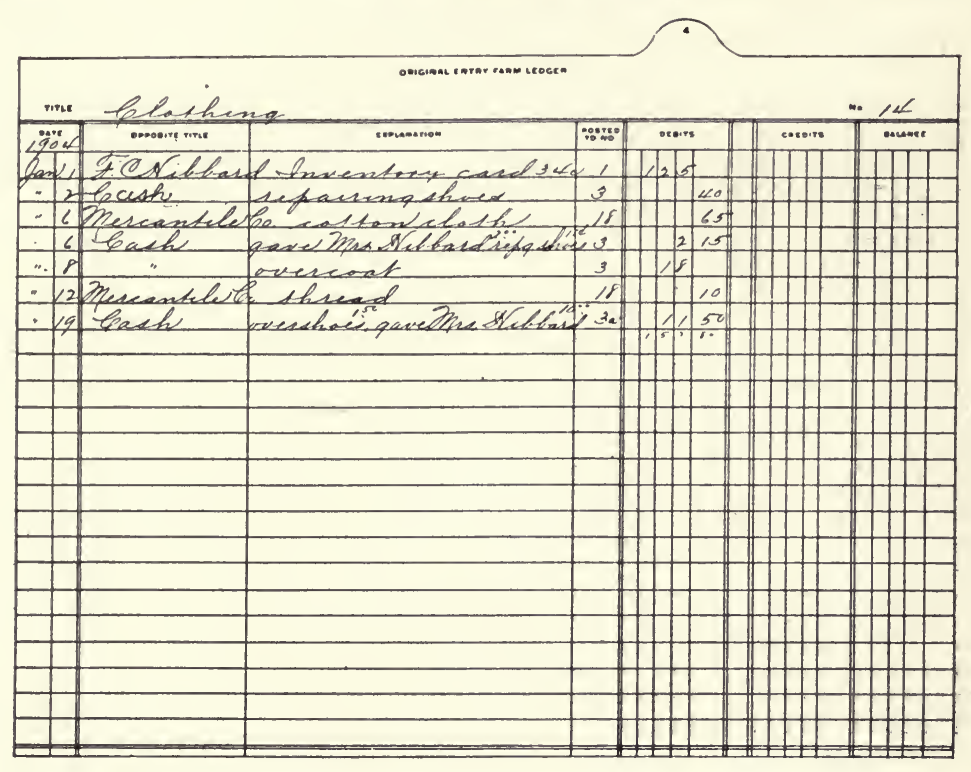

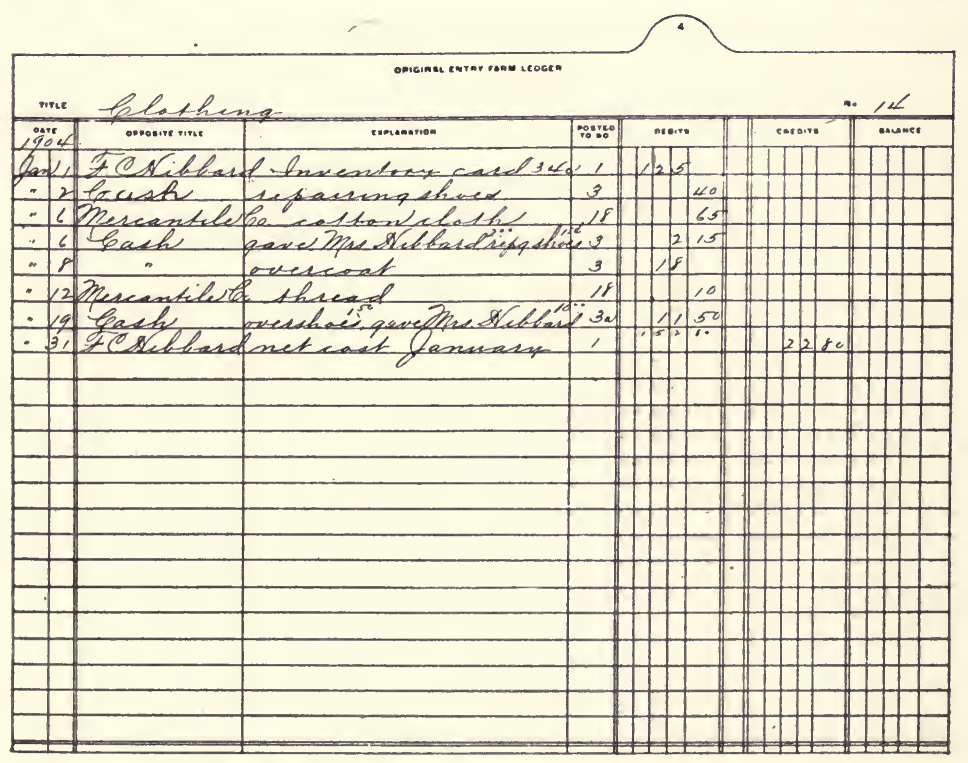

"A long head is never headlong." 


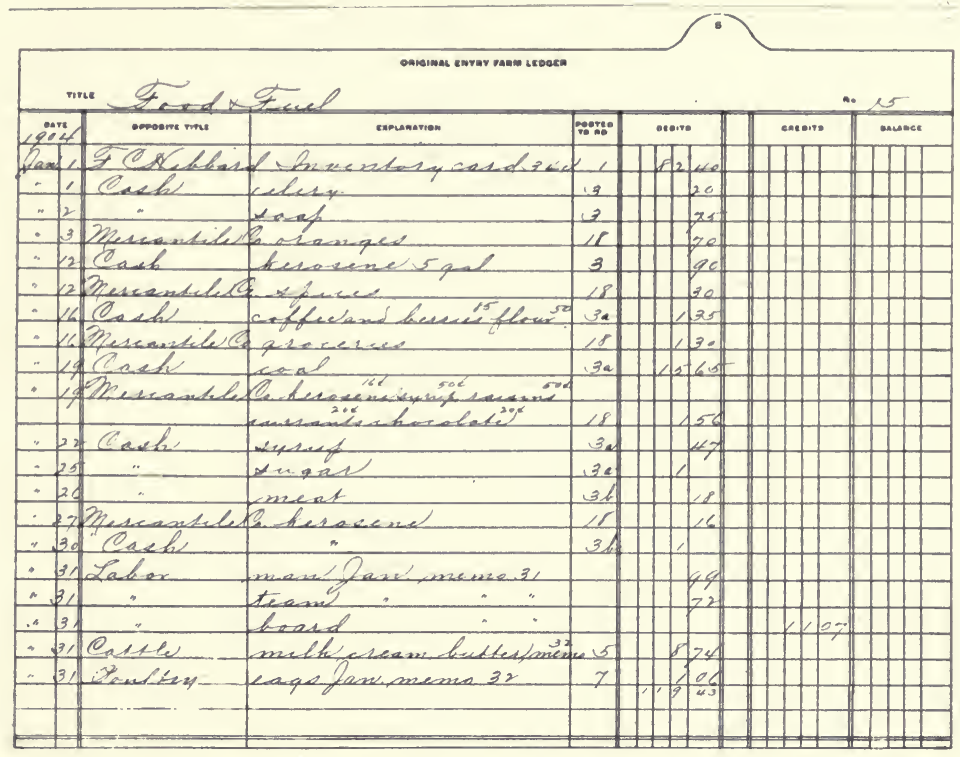

Duplicate card, showing method of handling this account.

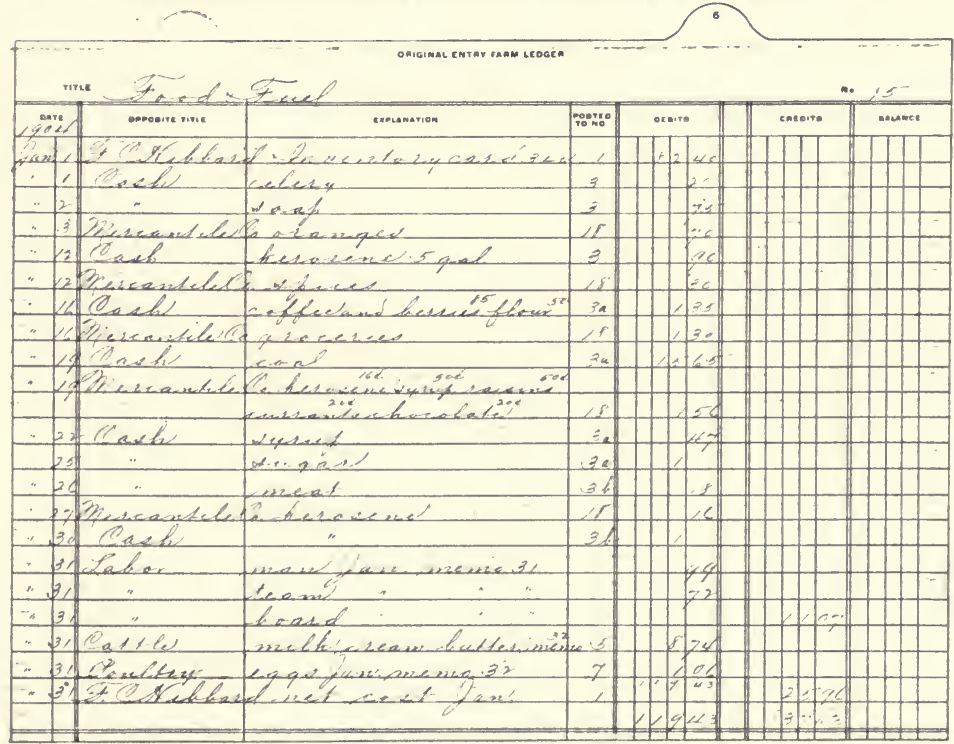

"A handful of common sense is worth a bushel of learning." 


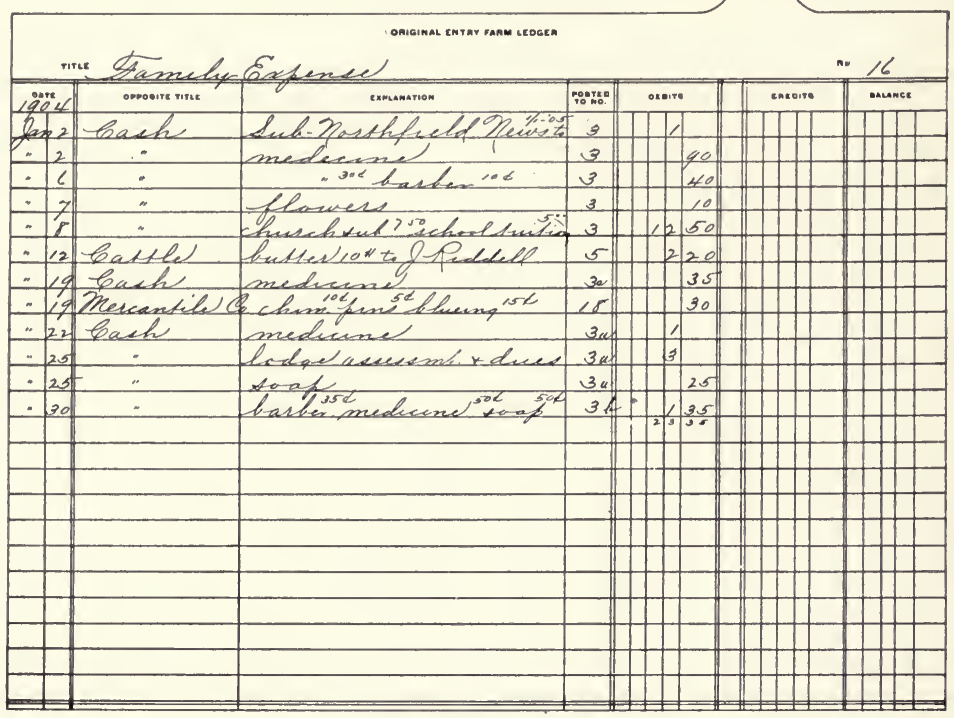

Duplicate card, showing method of handling this account.

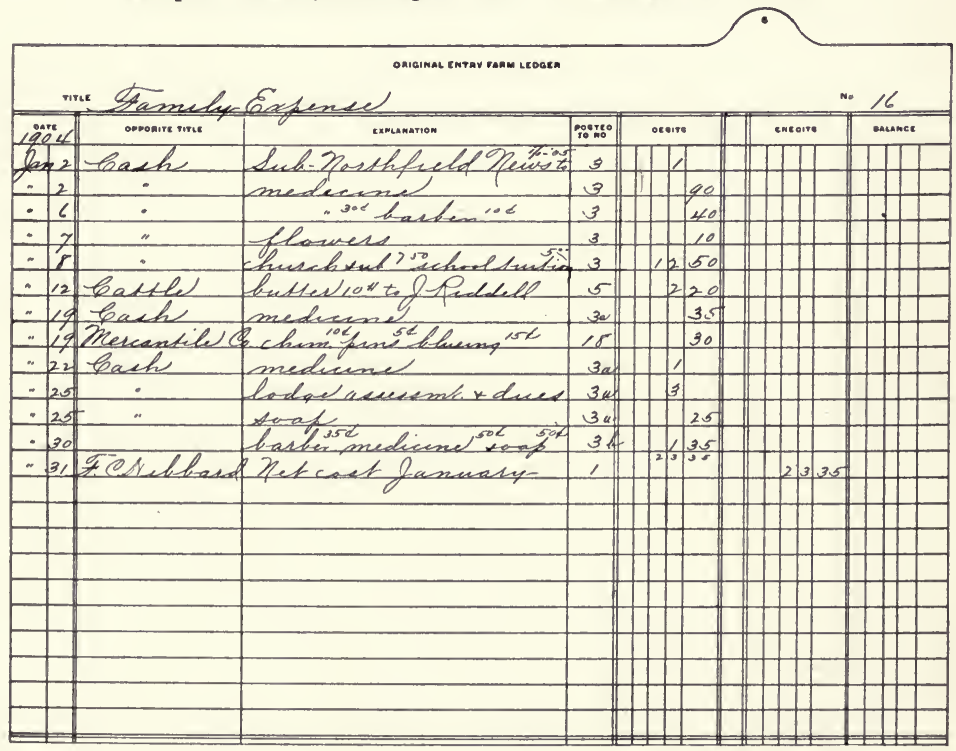

"A man who is not spoken of is not abused." 


\begin{tabular}{|c|c|c|c|c|c|c|c|}
\hline \multicolumn{8}{|c|}{ 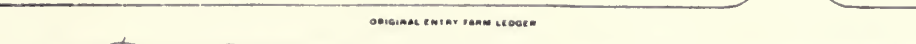 } \\
\hline mine & Tasmes & Expensel & & & \multicolumn{3}{|c|}{$m-17$} \\
\hline$[404$ & oesposire times & thensertion & ?ant: & neserve & coserene & sounce & \\
\hline end: & Gach & account book & $\exists$ & & & & \\
\hline & . & ledqex & 3a & tod & & & \\
\hline & $\cdots$ & Stationues & (3). & 1020 & $H$ & & \\
\hline$=\sqrt{3}$ & " & cutting sinel & (3) & 0.36 & & & \\
\hline & Fabor & 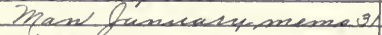 & & 22 & $H$ & H & \\
\hline$n$ & ", & Leamen " " & & 16 & & & \\
\hline & & & & 世 & & & \\
\hline & & & & 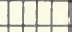 & & & \\
\hline & & & & & & & \\
\hline & & & & & &  & \\
\hline & & & & & t & 11 & \\
\hline & & & & & & & \\
\hline & & & & & & & \\
\hline & & & & & & & \\
\hline & & & & & & & \\
\hline & & & & & & H & \\
\hline & & & & & & & \\
\hline & & & & & & & \\
\hline & & & & & & & \\
\hline & & & & & & & \\
\hline & & & & & 1 & 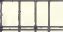 & \\
\hline
\end{tabular}

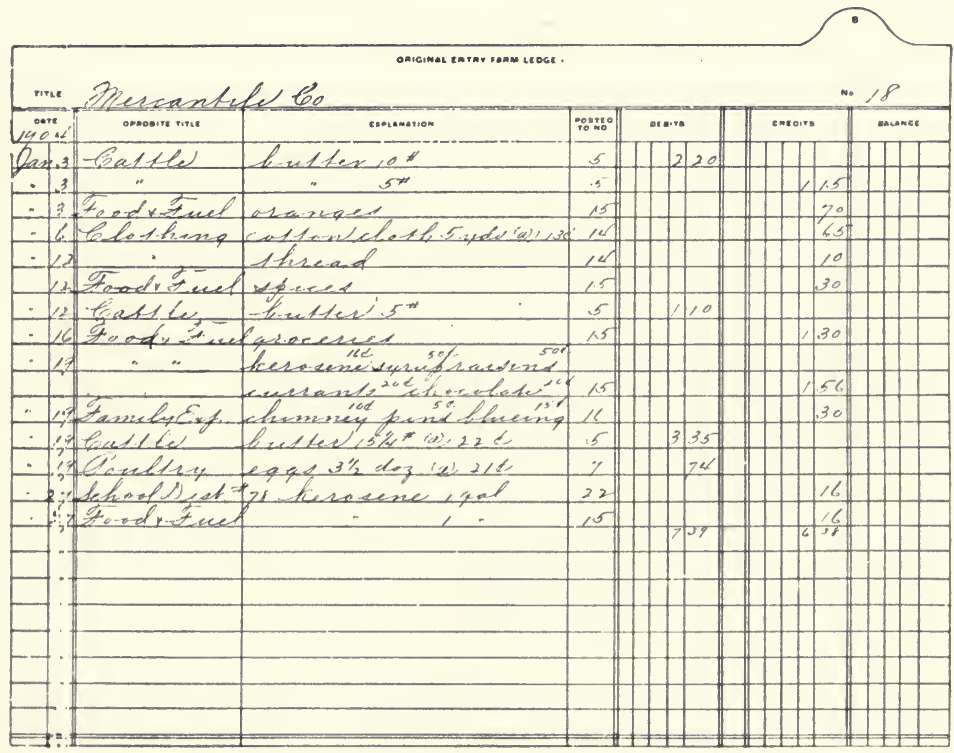

Better slip with foot than tongue,-Hubbard. 




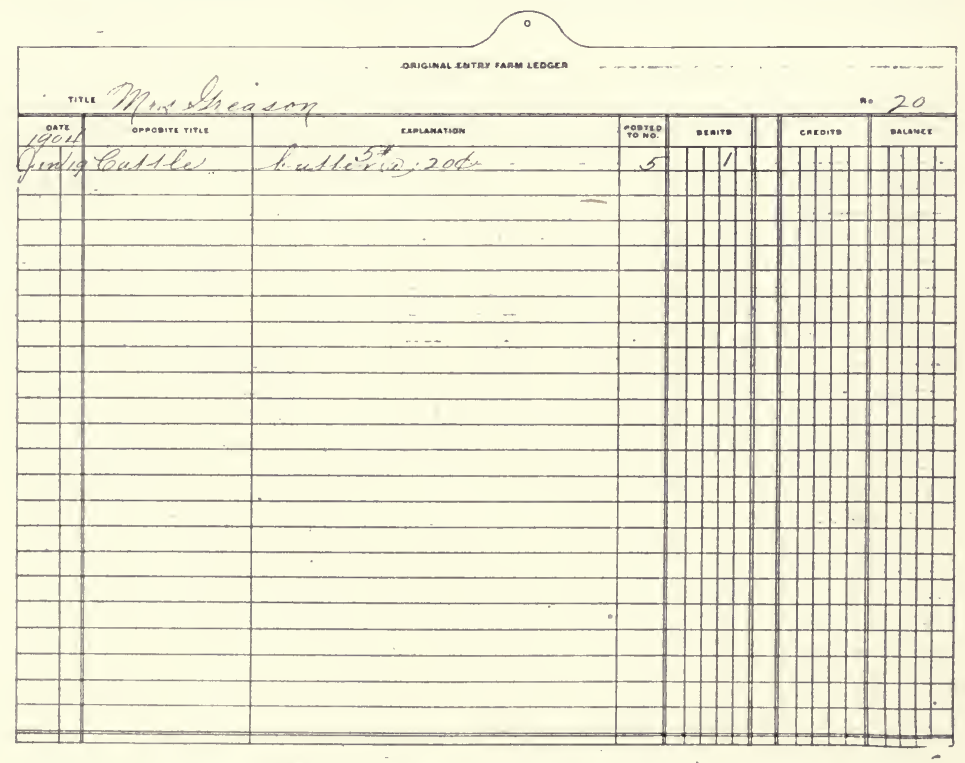

He that cannot obey, cannot command:-Hubbard. 


\begin{tabular}{|c|c|c|c|c|c|c|}
\hline & Grescen & terramero bo & & & & $=21$ \\
\hline ans & oprosine vince & ctonsanostion & $\because \because \cdots 0^{\circ}$ & ocen:s & cuscoin: & ....nones \\
\hline Cunats & - bavled & Ahuelsgalcandeseemm & +5 & tat: & & \\
\hline & & Fetrmateof ittqallia bod & & & & \\
\hline & & & & & 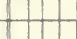 & 1 \\
\hline & & & & & & \\
\hline & & & & & & \\
\hline & & & & & & \\
\hline & & & & & 111: & H \\
\hline & & & & $+4+1$ & +1 & $H$ \\
\hline & & & & 10 & LI & 00 \\
\hline & & & & 111 & & \\
\hline & & & & & & \\
\hline & & & & & & $H$ \\
\hline & & & & & 4 & $H$ \\
\hline & & & & $\pi$ & 4 & 1 \\
\hline & & & & at & 1 & \\
\hline & & & & & & \\
\hline & & & & +1 & & \\
\hline & & & & +11 & 11 & 410 \\
\hline & & & & $H+$ & +1 & $H H$ \\
\hline 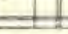 & $=$ & $=$ & & 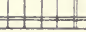 & 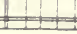 & D \\
\hline
\end{tabular}



Adversity is the parent of virtue.-Plutarch. 
FARM ACCOUNTS.
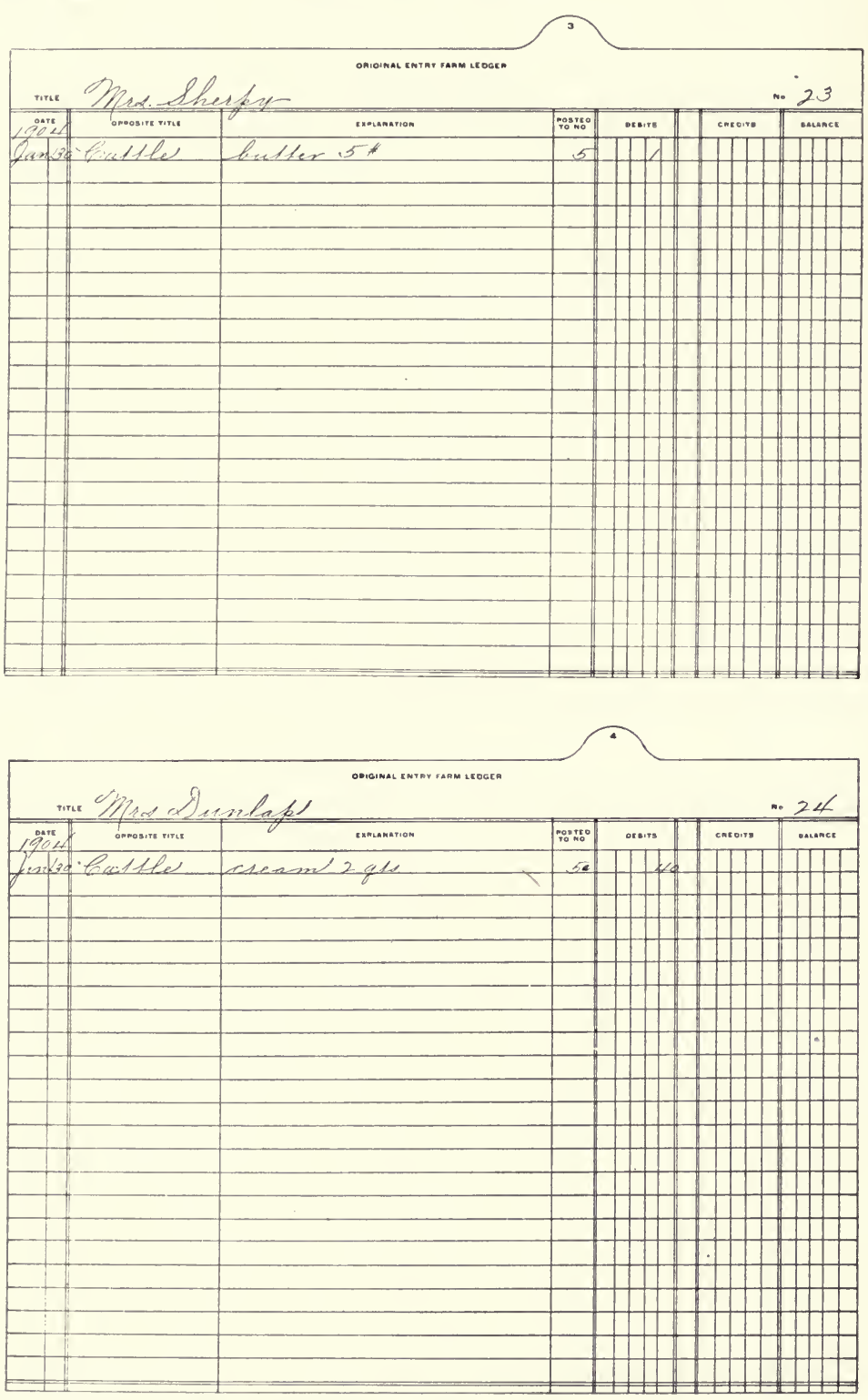

"Affairs like salt fish ought to be a good while soaking." 

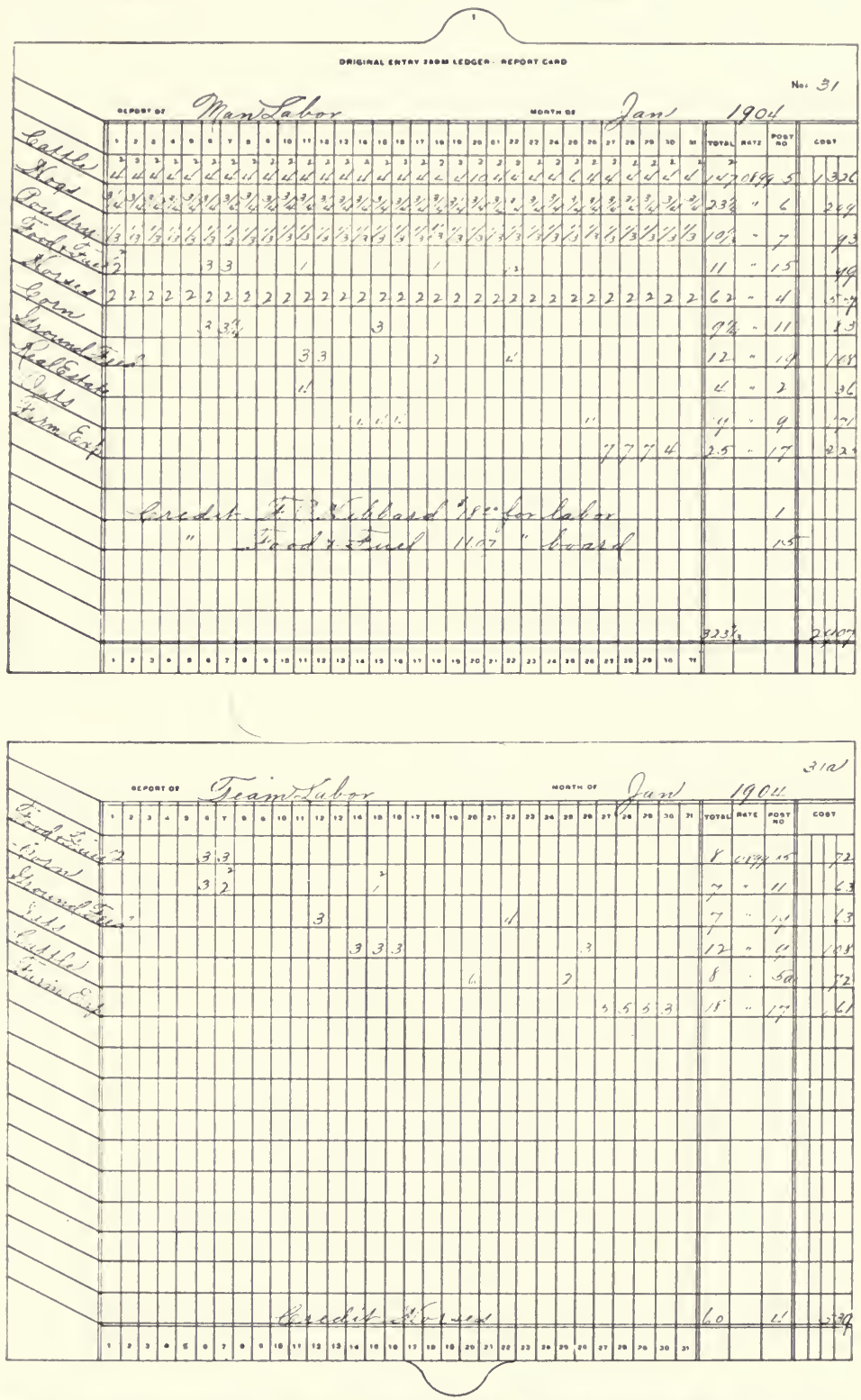

None preaches better than the ant, and she says nothing.-Franklin. 

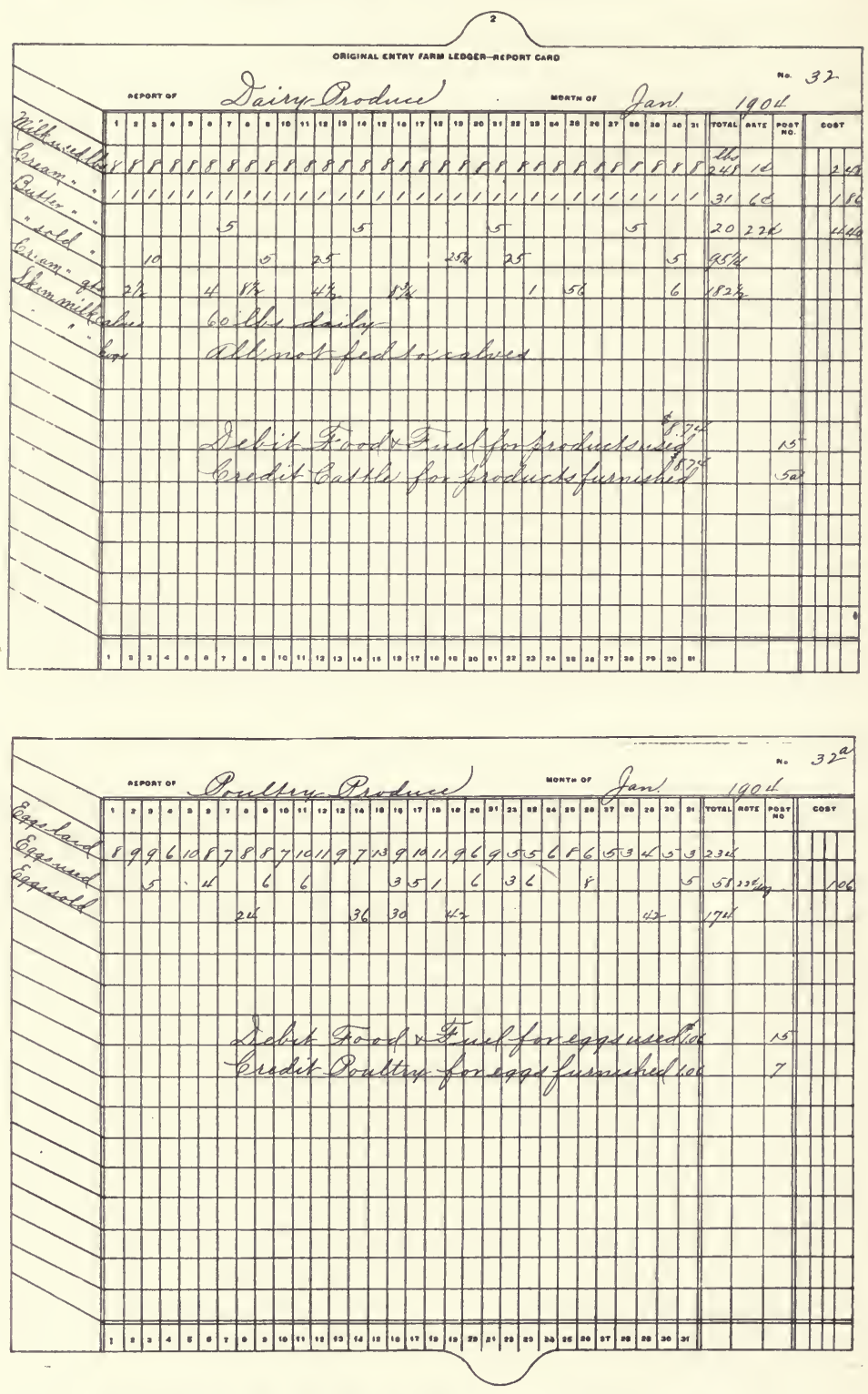

Avarice is the parent of all wickedness.-Claudianus. 


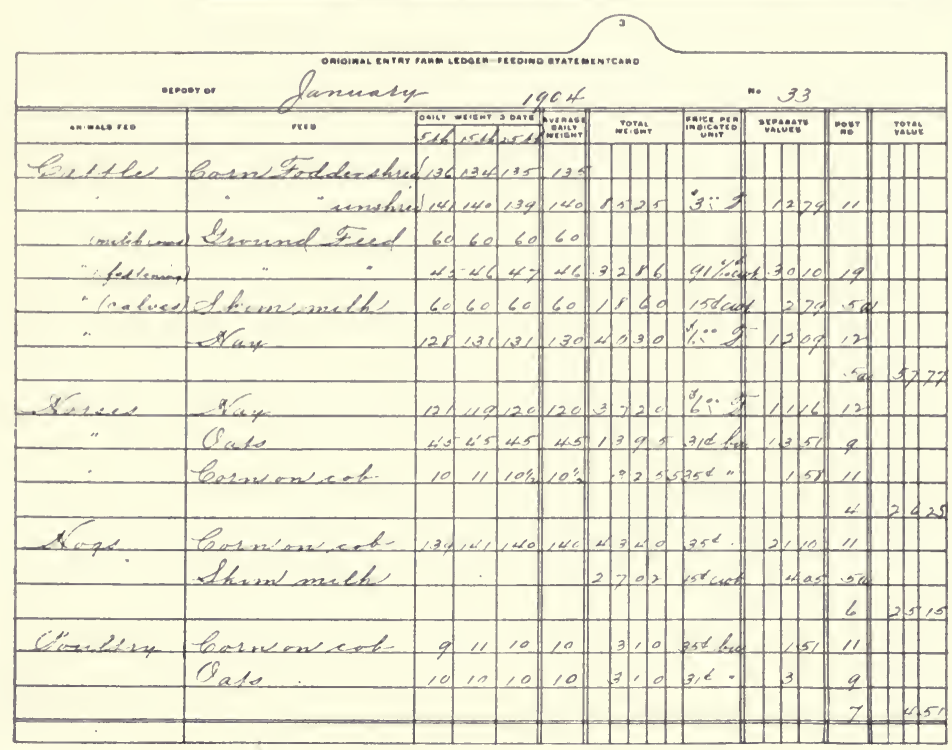

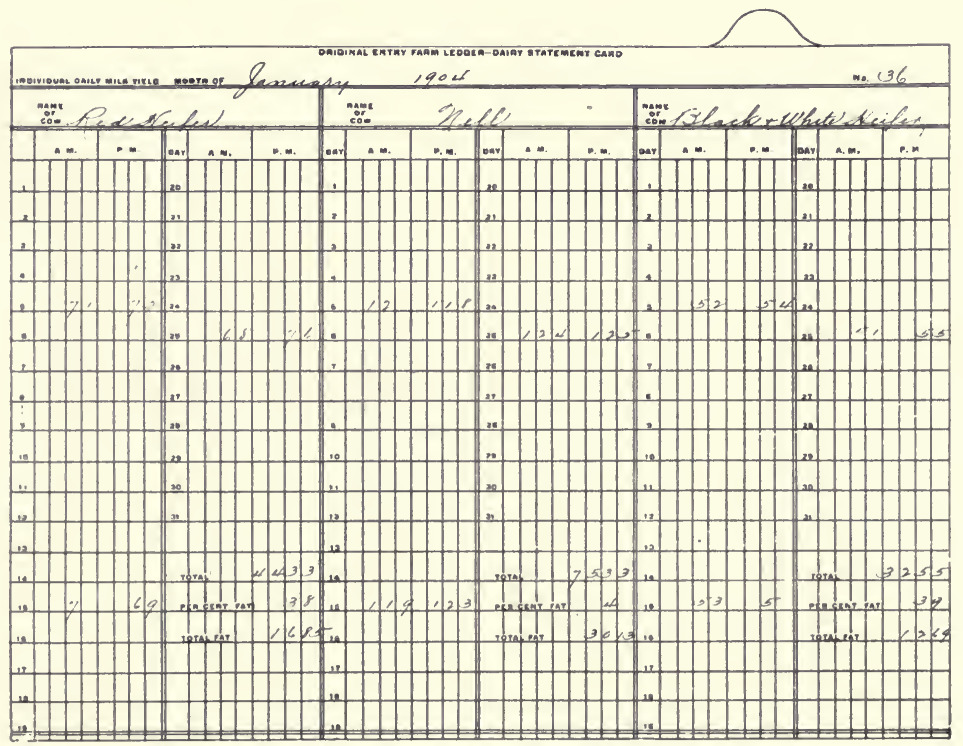

It is often better not to see an insult than to avenge it.-Seneca. 

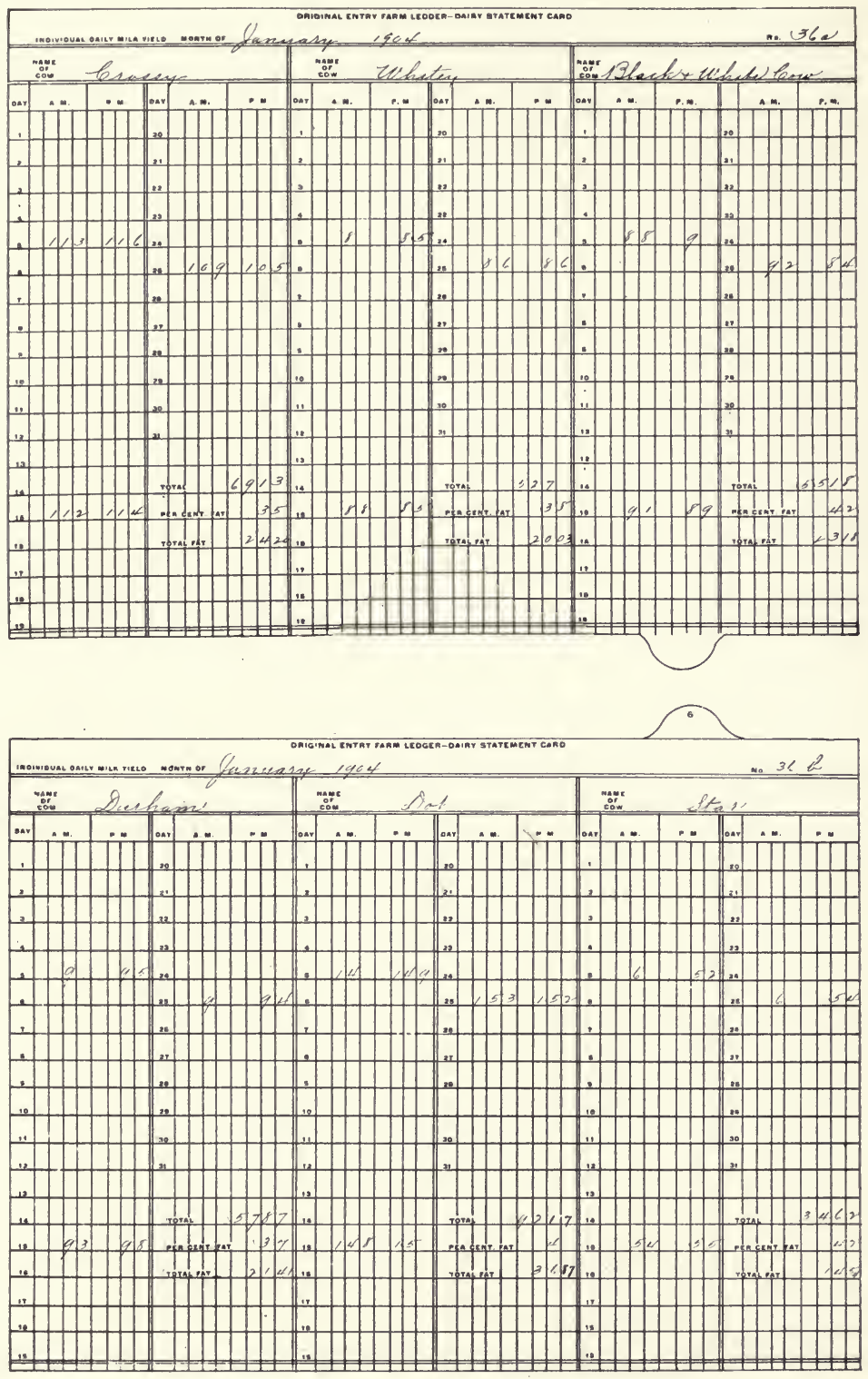

"Make the best of a bad bargain." 


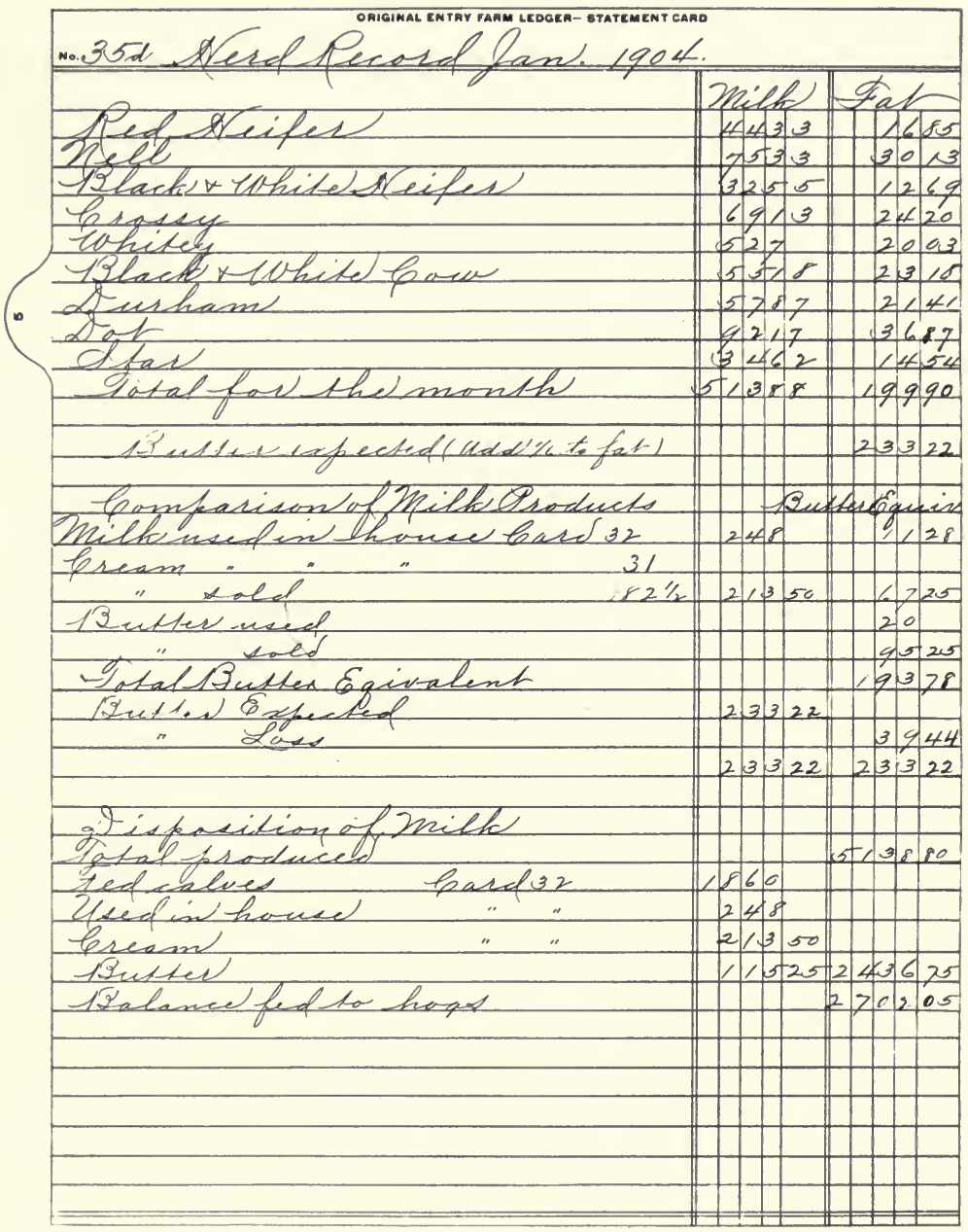

Get average per cent of fat by dividing total fat by total milk. It equals .039.

It is better to wear out than rust out.-Bishop Horne. 

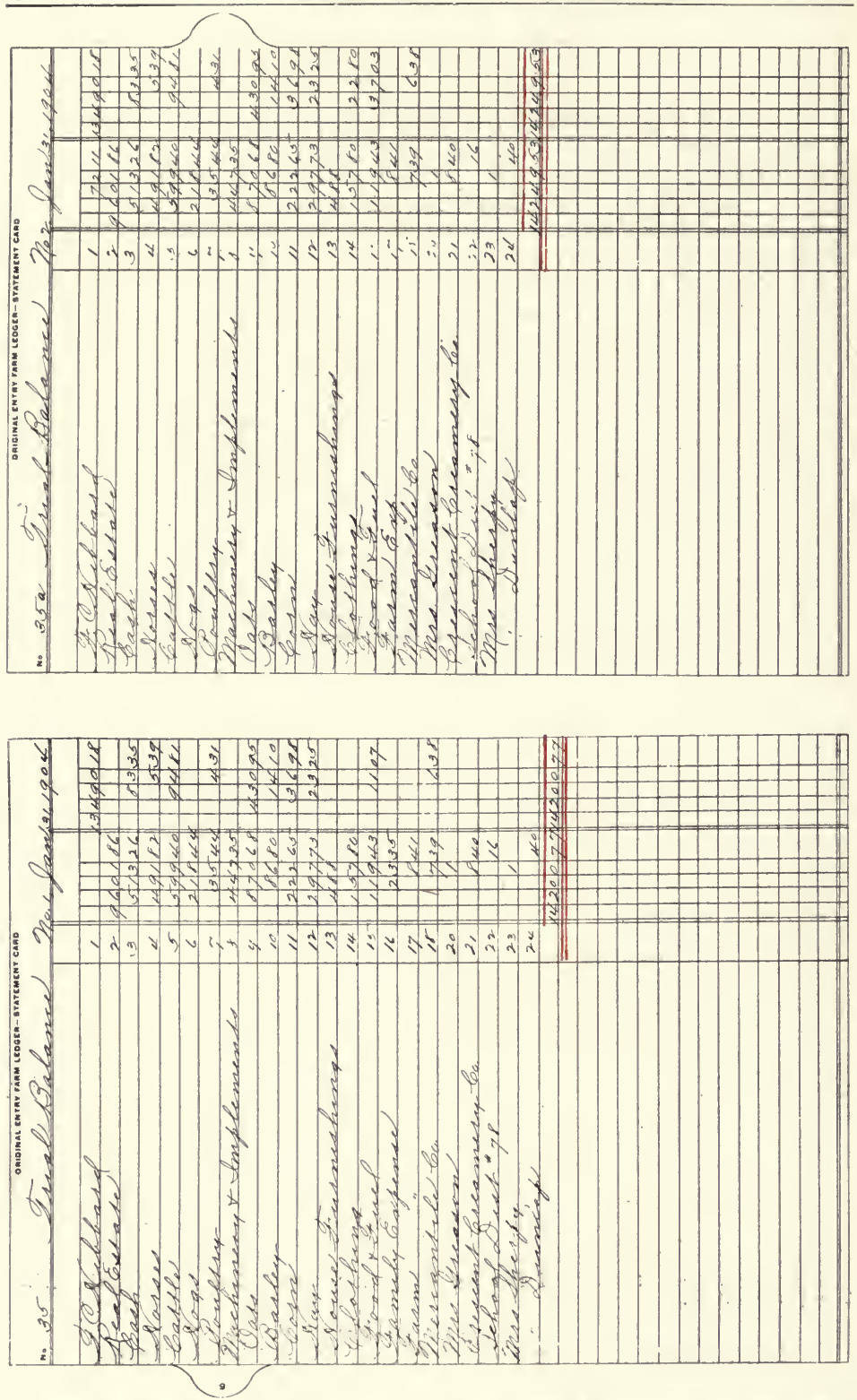

If you are an anvil be patient; if you are a hammer strike hard. - Ger. 


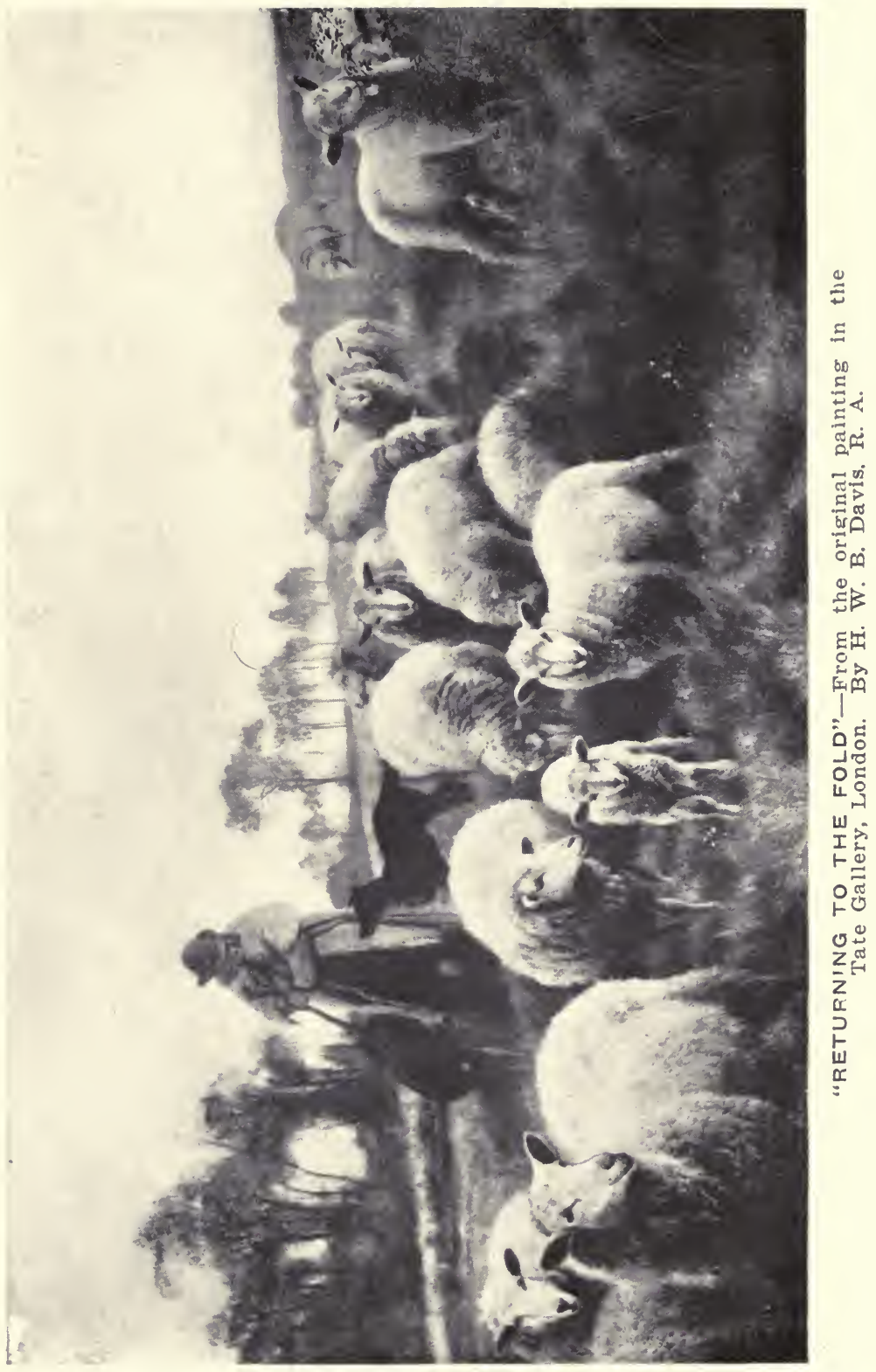




\section{CHAPTER VII.}

\section{LABOR ON THE FARM.}

Where the labor is hired it is easy enough to determine its cost, but where it is furnished almost wholly by the members of the family it is quite another thing. The labor herein, unless otherwise specified, was furnished by the family. It seems fair to assume that the head of the family, F. C. Hibbard, should receive credit for it. The rate of wages during January is $\$ 18.00$ per month and board, figured at $\$ 2.50$ per week. The rate per hour for the team is considered the same as that for the man.

\section{PRICES OF FARIM PRODUCTS.}

The prices of feeds and products used during the month are taken from the local paper, The Northfield News, when given, and by inquiry when not. They are as follows: Corn fodder, shredded and unshredded, $\$ 3$ per ton; hay $\$ 6$ per ton; oats 31c per bushel; corn 35c per bushel; barley 35 c per bushel; whole milk $\$ 1$ per hundred; skim milk 15 cents per hundred; cream 6c per lb.; butter 22c per lb.; eggs $22 \mathrm{c}$ per dozen.

\section{GROUND FEED.}

It the beginning of the month there was on hand, as noted in the inventory, some oats and barley, ground and ready to be used in making up the feed. This was mixed together and fed. On the 12th of the month six sacks each of oats and barley were taken to the mill and ground. Before grinding, the sacks were weighed; the weight of the oats being $470 \mathrm{lbs}$. and of the barley $672 \mathrm{lbs}$. Because of the inconvenience in weighing either at home or at the feed 
mill, it was assumed that as the sacks used in taking the grain to the feed mill later were uniform in size, the weight of the two grains would hold in the same proportion as above.

By reference to card 33 -Feeding Statement-it will be seen that the animals ate 3286 pounds of ground feed. The amount of each grain in the ground feed should now be ascertained and the value in money computed. 470 plus 672 gives 1142 pounds in a mixture of ground feed $\frac{470 \times 3.86}{1142}=$ 1352 pounds of oats and $\frac{672 \times 3286}{1142}=1934$ pounds of barley. Debit Ground Feed with each separately and credit Oats and Barley respectively, cards 9 and 10 .

Ground feed should have been debited and oats and barley credited at the time the grain was taken to the mill to be ground. A defect in the memoranda furnished has made it necessary to handle it differently. The simplest and most direct method of handling a transaction is the best.

\section{MAN LABOR.}

Having posted all the transactions and made all the records from the January memoranda, you should next transfer the facts from the auxiliary to the principal cards, or post from the auxiliary cards.

The Labor Record cards should be added from left to right. The man worked $323 \frac{1}{3}$ hours. His labor is considered worth the prevailing rate $\$ 18$ per month and board. The board is considered worth $\$ 2.50$ per week or $\$ 11.07$ for the month of 31 days. The man labor thus cost $\$ 29.07$. Dividing this by $323 \frac{1}{3}$, the hours worked, the rate is found to be $\$ .0899$. Multiplying this rate by the hours gives the cost of each enterprise. The sum of these costs equal $\$ 29.07$. Debit each enterprise with its cost, Cards 5, 6, 7, 15. 4, 11, 19, 2, 9, 17. Credit F. C. Hibbard for labor performed $\$ 18.00$ and Food and Fuel for the board $\$ 11.07$. 


\section{TEAM LABOR.}

The rate per hour is assumed to be the same as paid for man labor \$.0899. This would seem to be fair inasmuch as the man averaged over ten hours a day and the labor of a man is usually considered an offset for the labor of a team an equal number of hours. The team is charged for its care and feed separately, cards 31 and 33. Charge the enterprises receiving the benefit of Team Labor, cards 15, 11, 19, 9, כa, 17, and credit Horses card 4.

\section{DAIRY PRODUCE.}

On card 32, is recorded the disposition of milk, cream and butter. The prices put on the milk, cream and butter used in the house are the prevailing ones. Debit Food and Fuel, card 15, with products used and credit Cattle, card 5a.

\section{POULTRY PRODUCE.}

On the reverse side of card 32 , is a record of the eggs laid, used and sold. The eggs sold were recorded at the time of sale. The eggs used should now be posted by debiting Food and Fuel, card 15, \$1.06, and crediting Poultry, card $7, \$ 1.06$.

\section{FEEDING MEMORANDA.}

Owing to the inconvenience of weighing the feed given to the live stock every day, it was determined to accept the average of three representative days' feeding as the average for the month. On card 33, the weight of the several kinds of feed has been recorded as taken on the 5th, 15th, and 25 th of the month. The total quantities and values should now be computed, and entered in the appropriate columns of that card.

"The unsuccessful believe in luck; the successful believe in work." 
The average market price for the month is used in computing the value of the products fed out, and for January was as follows: Corn fodder $\$ 3.00$ per ton; skim milk $15 \mathrm{c}$ per hundred; hay $\$ 6.00$ per ton; oats $31 \mathrm{c}$ per bushel; corn on the * cob 35c per bushel; barley 35c per bushel.

The cattle were fed shredded corn fodder, $136 \mathrm{lbs}$. on the 5th, 134 lbs. on the 15th, and 135 lbs. on the 25th, making an average of $135 \mathrm{lbs}$. for each of the three days when the weights were taken. The daily average weight of unshredded fodder is found to have been $140 \mathrm{lbs}$. Thus, the cattle consumed daily during the month of January 275 lbs. of shredded and unshredded corn fodder. The total weight for the 31 days of the month was 31 times 275 lbs. or 8525 lbs., and the value of this quantity at $\$ 3.00$ per ton is $\$ 12.79$.

The ground feed, hay, and skim milk fed the cattle should likewise be figured. The feecs fed the horses, hogs, and poultry should also be computed and the proper extensions made.

Cattle should be debited, card 5a, with the price of feeds consumed, \$57.77. And Corn, card 11, (\$12.79), Ground feed, card 19, $(\$ 30.10)$, Cattle, card 5a (\$2.79) skim milk fed the calves, and Hay, card 12 (\$12.09), credited. Horses should be debited, card $4,(\$ 26.25)$ and Hay, Oats and Corn, credited cards 12. 9, and 11 respectively. Hogs should be debited, card $6(\$ 25.15)$ and Corn and Cattle credited, cards 11 and 5a respectively. Poultry should be debited, card $\tau$ (\$4.51) and Corn and Oats credited, cards 11 and 9, respectively.

\section{DAIRY STATEMENT CARD.}

This is a record of the milk produced by each cow during the month. It may be recorded each day. In this instance the milk was weighed three days during the month or for

* Use $72 \mathrm{lbs}$, to the bushel of corn on the cob.

"Our ships would come in if we'd go out with a tug to meet them." 
six milkings. These weights are added together, divided by 3 , the number of days represented, and multiplied by 31 , the days in January.

The tests are recorded as made and multiplied by the pounds of milk which gives the total fat.

\section{HERD RECORD.}

This is a compilation of facts from cards $36,36 \mathrm{a}$, and $36 \mathrm{~b}$ showing the milk and fat produced. It also gives a comparison of facts from card 32 of the milk products showing the butter unaccounted for or apparently lost through improper skimming and a statement of the disposition of the milk and its products.

By dividing the total pounds of fat produced during the month by the total milk expressed in units, the average per cent of fat is ascertained. In January it is .039 approximately. To find the amount of butter in milk, first determine the amount of fat it contains by multiplying the per cent test of fat by the pounds of milk. To this fat add one-sixth of itself and the result should be the total butter content. The amount of butter in cream may be found by taking its per cent test and multiplying it by the pounds of cream to get the total fat content. To this fat add one-sixth of itself and the result should be the total pounds of butter.

\section{TRIAL BALANCE.}

A trial balance is a trial to see that the ledger cards balance or the footings of the two sides are equal. It consists of a list of each open account in the ledger showing the name of the account and the total debits and total credits set opposite it. These debits and credits must equal each other before proceeding.

Mind your own business and thus give others a chance to mind theirs. -Hubbard. 
In preparing for a trial balance take a finely sharpened lead pencil and add the sides of each account placing the footings directly under the line following the last entry on each side of the account. Take a Statement card and write the name of each account with its debit and eredit amounts in the columns provided. Then add these two columns for comparison.

Since in posting to the cards every transaction must have an equai amount of debits and credits, the total sum of these debits and these credits should equai each other. If they do not, the ledger is out of balance because an error has been made (1) in posting, or (2) in adding the sides of the account, or (3) in transferring the accounts to the trial balance or (4) in adding the trial balance.

As you do not know just where the error is it will be necessary to systematically test each of the four conditions above noted. Commence with the first posting and see that the debits and credits are equal and take up severally the following transactions in like manner, placing a dot or a check mark after each amount on the cards. Look through the cards carefully to see if there are any amounts not having dots or check marks beside them. If there are, there is something wrong. (2) Add again the sides of each account and (3) see that the sums are properly carried to the Trial Balance. Now (4) add the Trial Balance carefully.

Working through this routine should bring the desired results. If the error is not found, go over the routine again and again until the work is correct.

\section{INVENTORY ON JANUARY 31st.}

The inventory as of the last day of the month should now be taken so that the accounts which are not a part of the farm business may be charged against the proprietor. See chapter III and proceed as instructed on page 30 .

"The only real enemy one has is himself." 


\section{CLOTHING, FOOD AND FUEL, FAMILY EXPENSE, HOUSEHOLD FURNISHINGS.}

These accounts should ordinarily be classed as Business Accounts, but since they have nothing whatever to do with the farm production, yet are a necessary part of man's living, the net cost of each should be charged to the proprietor (F. C. Hibbard) and the account credited with that amount.

Before the net cost of each of these accounts can be ascertained, a reference must be made to the inventory made at this time-card $34 \mathrm{~g}$. Clothing is estimated to be worth $\$ 135$, and Food and Fuel $\$ 82.40$. In determining the net cost of these accounts these inventories must be considered as a credit. Thus, Clothing has d debit of $\$ 157.80$ and considering the inventory $\$ 135$ as a credit, the net cost is $\$ 22.80$. See duplicate card 14 showing Clothing credited $\$ 22.80$, and card *1 showing F. C. Hibbard debited $\$ 22.80$.

Food and Fuel has an inventory of $\$ 82.40$. Considering this as a credit the net cost is found to be $\$ 25.96$. See duplicate card 15. Credit Food and Fuel and debit F. C. Hibbard \$25.96. Family Expense has no inventory to consider so it is credited with its total debit $\$ 23.35$ and F. C. Hibbard debited a like amount. Since the inventory of Household Furnishings is equal to its total cost, there is no transfer entry to make.

These four accounts are very important ones, since they represent expenditures that are too often the source of financial embarrassment and distress. Even if no attempt is made to make a complete record of the business transacted, these accounts should never be overlooked.

\section{SECOND TRIAL BALANCE.}

A second trial balance should now be taken to determine the condition of the ledger since charging the proprietor

*F. C. Hibbard-Closed Ledger, page 83.

"Easy money is hard to keep.", 
with the living expenses as above. It is apparent that these transfers might have been made before taking the first trial balance and thus obviated the necessity for a second one, but it is safer for the beginner to check himself as often as practicable. This Trial Balance is shown on card 35a. This gives the true condition of the ledger at the close of Januare.

\section{BUSINESS STATEMENT.}

A Business Statement is one made to slow the *losses or tgains of the business. It also shows the losses or gains on each account separately. It naturally shows the cost and receipts of each of the accounts representing the things produced, bought, or sold for the purpose of gain. Such accounts used in January are Real Estate, Horses, Cattle, Hogs, Poultry, Machinery and Implements, Oats, Corn, and Farm Expense.

This statement is made from the Trial Balance and Inventory in a manner hereafter explained.

Take the statement card, and head it like card 35o. Referring to the second Trial Balance: Take the first Business Account-Real Estate-and write the name on the second line of the card and follow as illustrated with its cost-the debit in the Trial Balance. Write underneath this the present value (Inventory). Subtracting the present value from the cost a loss of $\$ 1.86$ is shown. Take the next Business Account-Horses-and to its receipts (credit side on second Trial Balance) add its inventory and from this total subtract its cost (debit side on second Trial Balance) and a loss of $\$ 26.43$ is shown. Likewise handle the remaining Business Accounts.

\section{FINANCIAL STATEMENT.}

A Financial Statement is one made to show our tresources and \$liabilities. It is made from the Trial Balance

*A loss is a decrease of capital.

tA gain is an increase of capital.

tA resources is anything we have of value.

A liability is anything we owe.

Hear no ill of a friend, nor speak any of an enemy. - Franklin. 
and Inventory. It contains a list of the values of the ledger accounts with their titles appearing in the Inventory together with the accounts and values appearing in the Trial Balance whose difference shows something due us or that we owe others.

The difference between this list of resources and liabilities is the net capital. Another way to determine our net capital is to add our net gain, or subtract our net loss from our net investment. It is thus apparent that in closing this month the difference between our resources and liabilities is equal to the sum of our net investment and net gain. See card 35c.

\section{CLOSING THE LEDGER.}

This is a process undertaken at stated times for the purpose of closing up or ruling up the several accounts in the ledger. It is really an unnecessary process with the card system unless we wish to discontinue business for as soon as one card is full the account is transferred to another one and the Business and Financial Statements give a complete exposition of the results and standing of the business. However, it is a nice process and serves to better acquaint the student with the relationship existing between the accounts. The ledger should never be closed until the Business and Financial Statements have been made, as these give a thorough test of the condition of the ledger for closing. This book gives the open ledger (its condition after posting) and the closed ledger (its condition after the processes of closing have been completed). In closing a ledger take an Inventory and a Trial Balance and make a Business and Financial Statement; open a Loss and Gain account; into it transfer all losses and gains shown in the Business Accounts.

Open a balance Account; into it transfer all resources and liabilities shown in the Financial Accounts and the inventories from the Business Accounts.

Be always ashamed to catch thyself idle.-Franklin. 


\section{CLOSE BUSINESS ACCOUNTS INTO LOSS OR GAIN.}

A business account which has no inventory is closed by writing on the less side in red ink the difference between the two sides. The date, Loss and Gain, and card number of the Loss and Gain Account should also be written. This difference should be transferred in black ink to the opposite side of the Loss and Gain Account. The account should be ruled as shown in the closed ledger.

Where a Business Account has an inventory that is a resource, write the inventory on the credit side in red ink and transfer it in black ink to the opposite side of the Bal. ance Account and proceed as with an account without an inventory.

\section{CLOSE FINANGIAL ACCOUNTS INTO BALANCE.}

A Financial Account that balances (whose debits and credits are equal) is balanced by simply bringing down the totals opposite each other and ruling as on card 16 Family Expense. Where the two sides are unequal write on the less side in red ink the difference and carry this in black ink to the opposite side of the Balance Account and rule as on card 21.

If desired, the balance may be brought down underneath the ruled account instead of carrying it to the Balance Account. The ledger would then be open ready for business.

\section{THE USE OF RED INK.}

Red ink should be used sparingly. Its use is to emphasize or call attention to, and usually denotes something out of its proper place. When a red ink entry is transferred it is entered in black ink. Never make the same entry twice in red ink.

"After all, the man who is thorough, is the one who is wanted." 


\section{CHAPTER VIII.}

\section{CLOSED LEDGER.}

Inventory of real and personal property Jan. 31, 1904.

Real Estate: SE⿺ Section 4, Township 111, Range 19, 160 acres at $\$ 60$ per acre.

Horses: Topsy, black mare 6 years old $\$ 100$; Kitty, black mare 6 years old $\$ 100$; Nell, gray mare 14 years old $\$ 125$; Bill, gray gelding 16 years old $\$ 75$; . Maude, brown mare 2 years old $\$ 40$; Jess, brown mare 1 year old $\$ 20$.

Cattle: Cows-Nell, grade shorthorn 2 years old $\$ 30$; Black and White Heifer, grade shorthorn 2 years olı \$25; Red Heifer, grade shorthorn 2 years old $\$ 25$; Crossy, grade shorthorn 6 years old $\$ 30$; Whitey, grade shorthorn 10 years old $\$ 25$; Durham, grade shorthorn 8 rears old $\$ 30$; Black and White Cow, Jersey shorthorn 8 years old $\$ 25$; Dot, grade shorthorn 10 years old $\$ 30$; Star, grade shorthorn 7 years old $\$ 25$; Bangs, grade shorthorn 2 years old $\$ 25$; Holstein, grade Holstein 6 years old $\$ 22$.

Yearling Heifers-Daisy, grade shorthorn \$10; Belle, grade shorthorn $\$ 18$; Bess, grade Holstein $\$ 10$.

Fattening Cattle- Two red and white steers $\$ 95$.

Bull-Jack, grade shorthorn 1 year old $\$ 20$.

Calves-Five, $\$ 41$.

Hogs: 3 brood sows at $\$ 15 ; 8$ hogs $\$ 92 ; 7$ hogs $\$ 66.20$;

Poultry: Ninety chickens at $33 \frac{1}{3} \mathrm{c}$.

Machinery and Implements: Vehicles - 1 lumber wagon $\$ 25 ; 1$ old lumber wagon $\$ 5 ; 1$ two-seated road wagon $\$ 45$; 1 surrey $\$ 55 ; 1$ old one-horse buggy $\$ 5 ; 1$ pair light bobs $\$ 10 ; 1$ cutter $\$ 15$.

Machinery-1 binder $\$ 15 ; 1$ mower $\$ 18 ; 1$ hay rake $\$ 3$; 1 seeder $\$ 28 ; 1$ fanning mill $\$ 20 ; 1$ corn sheller $\$ 5 ; 1$ cream separator $\$ 40$; hay fork and rope $\$ 6.50 ; 1$ grindstone $75 c$.

"Better wear out shoes than sheets." 
Implements-1 sulky plow $\$ 35 ; 2$ old walking plows $\$ 5$; 1 spring tooth harrow $\$ \tau ; 1$ old wood-frame harrow $\$ 3 ; 1$ disk $\$ 10 ; 1$ two-horse cultivator $\$ 20 ; 1$ old two-horse cultivator $\$ 4 ; 1$ one-horse cultivator $\$ 2$.

Tools-Forks $\$ 1.25 ; 1$ scoop shovel $75 \mathrm{c}$; small tools $\$ 1.50$; hoes and rakes $50 \mathrm{c} ; 1$ set barn scales $\$ 8$.

Horse Equipment-1 double harness $\$ 20 ; 1$ old double harness $\$ 5 ; 1$ light double harness $\$ 25$; blankets $\$ 3$.

0ats: Market value $34 \mathrm{c}$ per bushel. $40 \mathrm{bu} .18 \mathrm{lbs}$. in feed boxes at barn; 3 bu. ground and in large sack.

Bin Measurements-No. 1-16 ft. 6 in. by $12 \mathrm{ft} .10 \mathrm{in.} \mathrm{by}$ $5 \mathrm{ft} .10$ in.; No. $5-12$ ft. 6 in. by 6 ft. by 3 ft. 7 in.; No. $6-$ $11 \mathrm{ft}$. by $6 \mathrm{ft}$. by $4 \mathrm{ft} .10$ in.

Barley: Market value 3ãc per bushel. $207 \mathrm{bu} .34 \mathrm{lbs}$.

Corn: Market value corn on cob 35c per bushel; fodder $\$ 3$ per ton.

Bin Neasurements-No: $1-19$ ft. 6 in. by 7 ft. 3 in. by $6 \mathrm{ft}$; No. $2-5 \mathrm{ft}$. by $5 \mathrm{ft}$. by $9 \frac{3}{4}$ in.; No. 3 -Round bin, diameter $S \mathrm{ft}$., height $4 \mathrm{ft}$.; 11,8s0 lbs. corn fodder.

Hay: Market value $\$ 6$ per ton. Mow No. $1-28 \mathrm{ft}$. by 30 ft. by $18 \mathrm{ft}$; No. 2--28 ft. by $30 \mathrm{ft}$. by $6 \mathrm{ft}$. 6 in.

House Furnishings: 2 kitchen ranges $\$ 30 ; 2$ tables $(1$ kitchen and 1 dining) $\$ 10 ; 9$ dining-room chairs $\$ 15 ; 4$ rocking chairs $\$ 7 ; 6$ kitchen chairs $\$ 2 ; 1$ large upholstered chair $\$ \tilde{5} ; 2$ upholstered chairs $\$ \tilde{5} ; 1$ bedroom suite $\$ 15 ; 2$ bedroom suites $\$ 20 ; 1$ bedroom suite $\$ \tilde{\text {; }}$; carpets $\$ 30$; bedding $\$ 50$; 2 couches $\$ 5$; 1 cot $\$ 1 ; 1$ parlor table $\$ 2 ; 1$ sideboard $\$ 15$; 1 wardrobe $\$ 50 ; 1$ secretary $\$ 15 ; 1$ secretary $\$ 5 ; 1$ clock $\$ 4$; 1 piano $\$ 150$; kitchen utensils and stove ware $\$ \tilde{5}$; dishes $\$ 25$; refrigerator $\$ 15$; churn $\$ 2$.

Clothing: Men's clothing $\$ 60$; women's clothing $\$ 75$.

Food and Fuel: Considered same as January 1st \$82.40.

"Cash: Balance on hand $\$ 429.91$.

*This was taken by actual count.

"To be humble to superiors is duty, to equals courtesy, to inferiors nobleness.", 

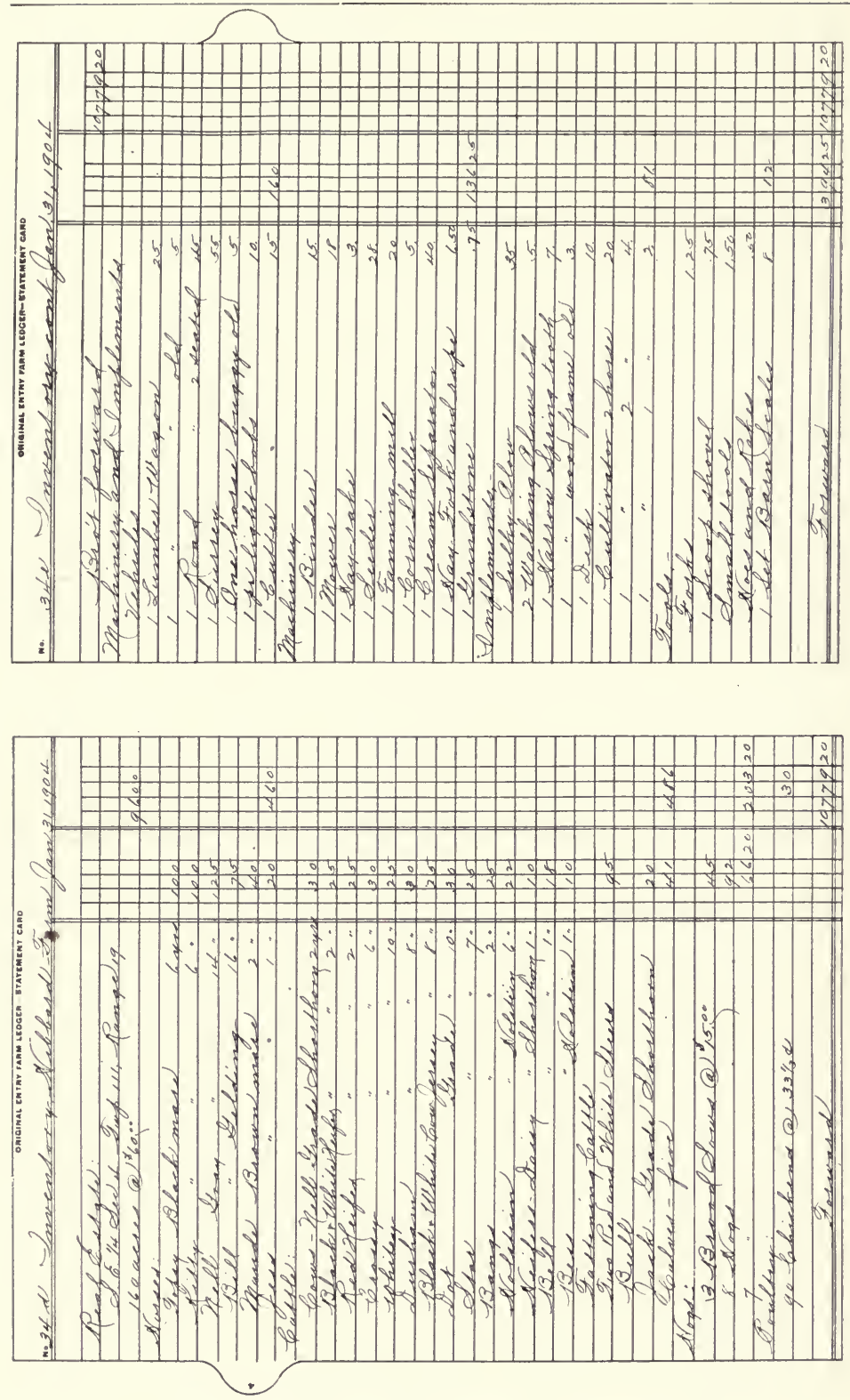

Familiarity breeds contempt.--Shakespeare 


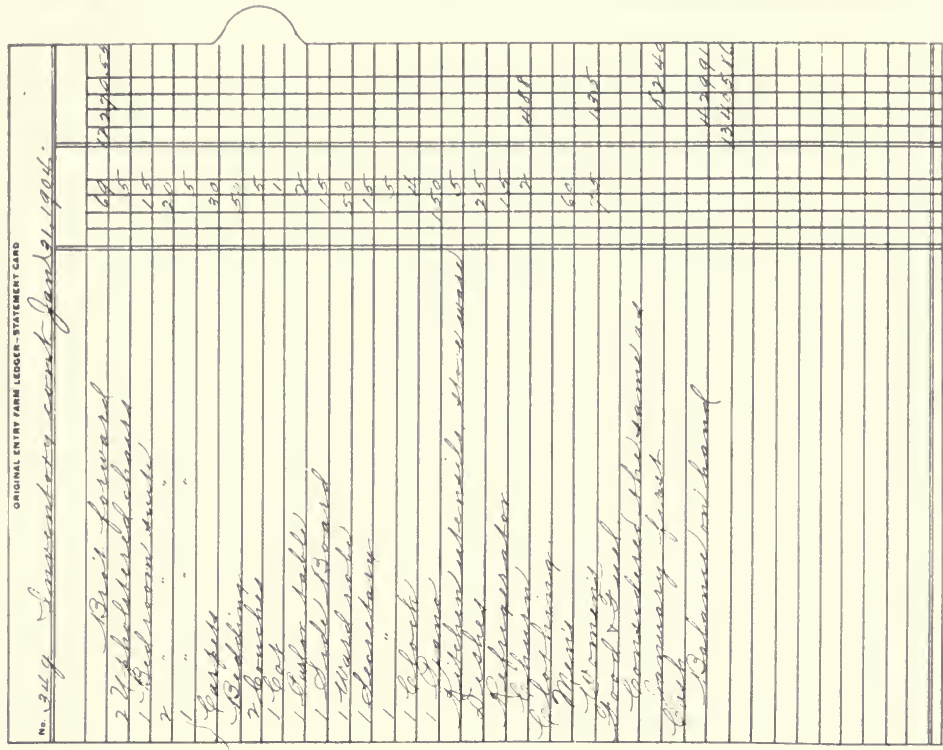

.

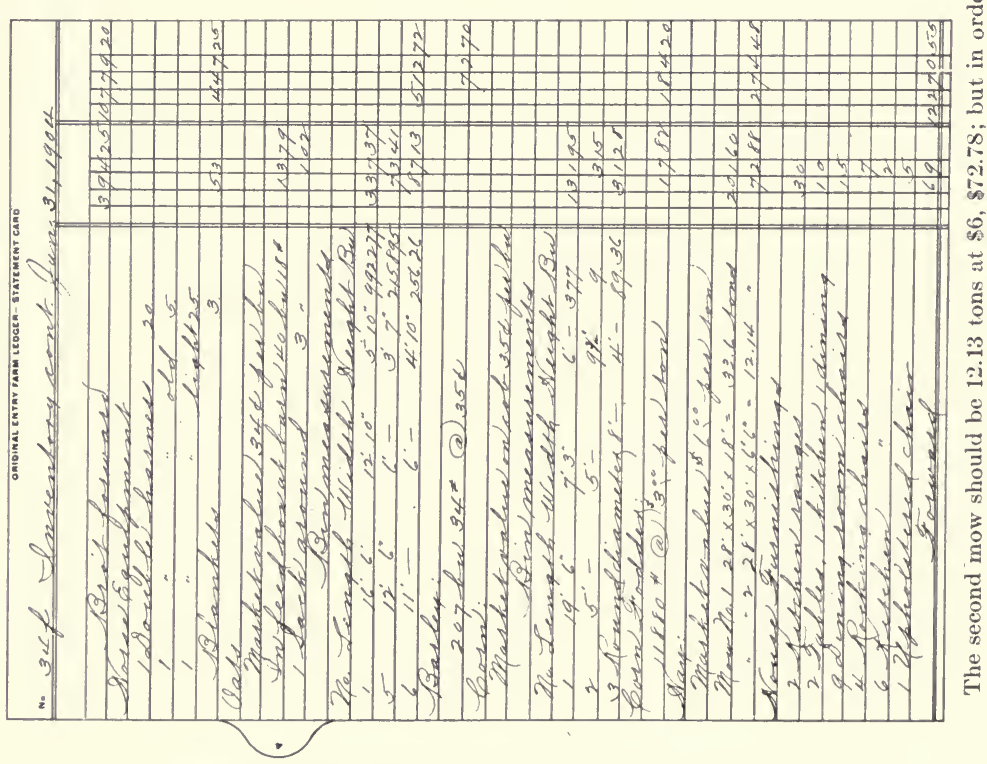

Deeds not words.-Beaumont and Fletcher. 

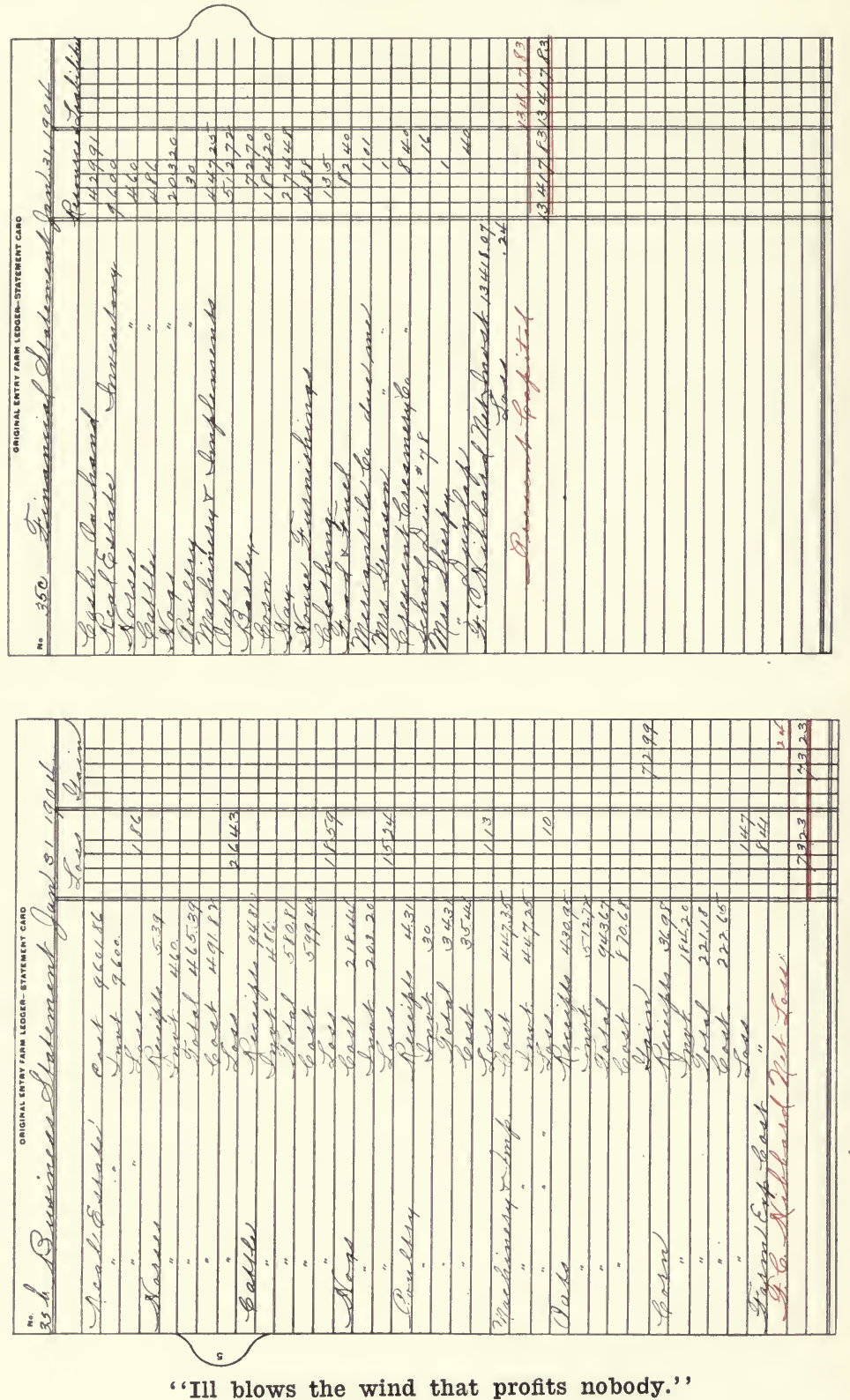


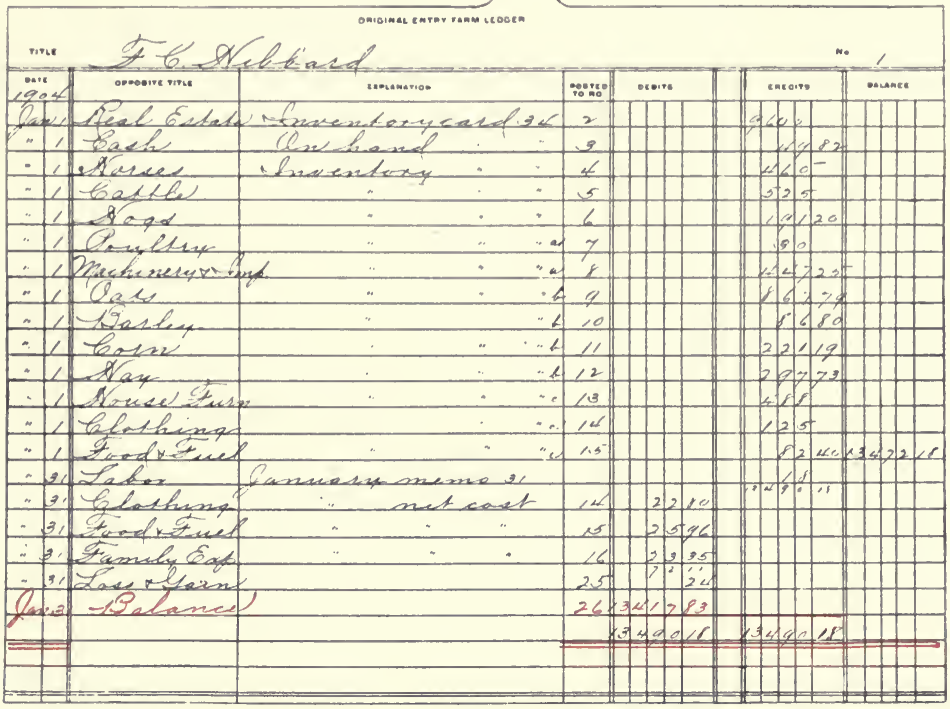

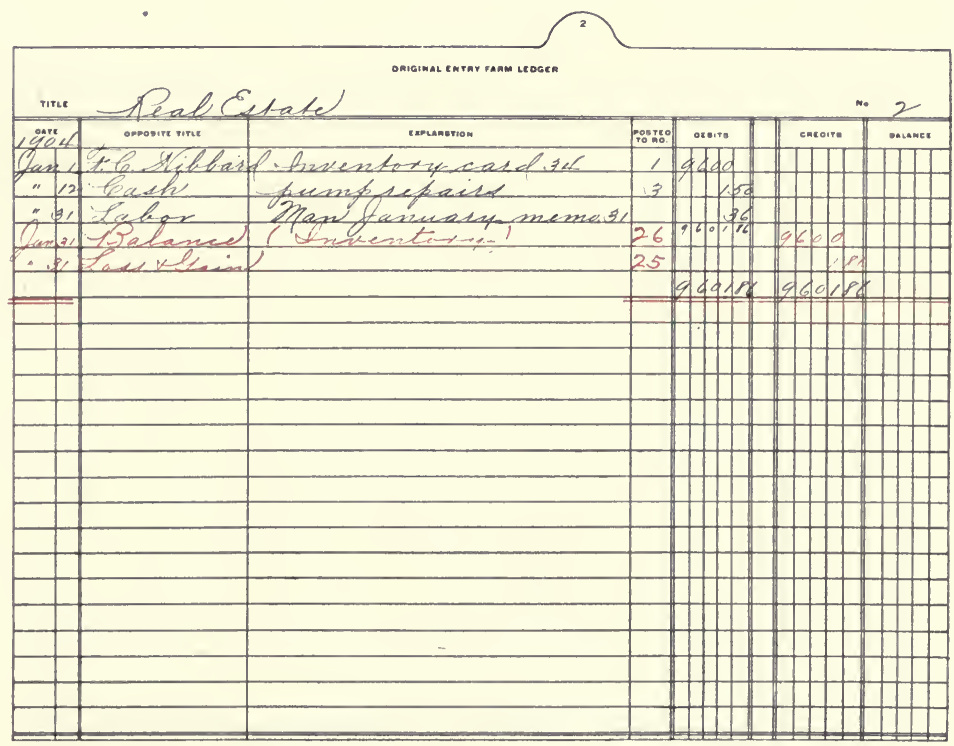

Every man's the architect of his own fortune.-French. 


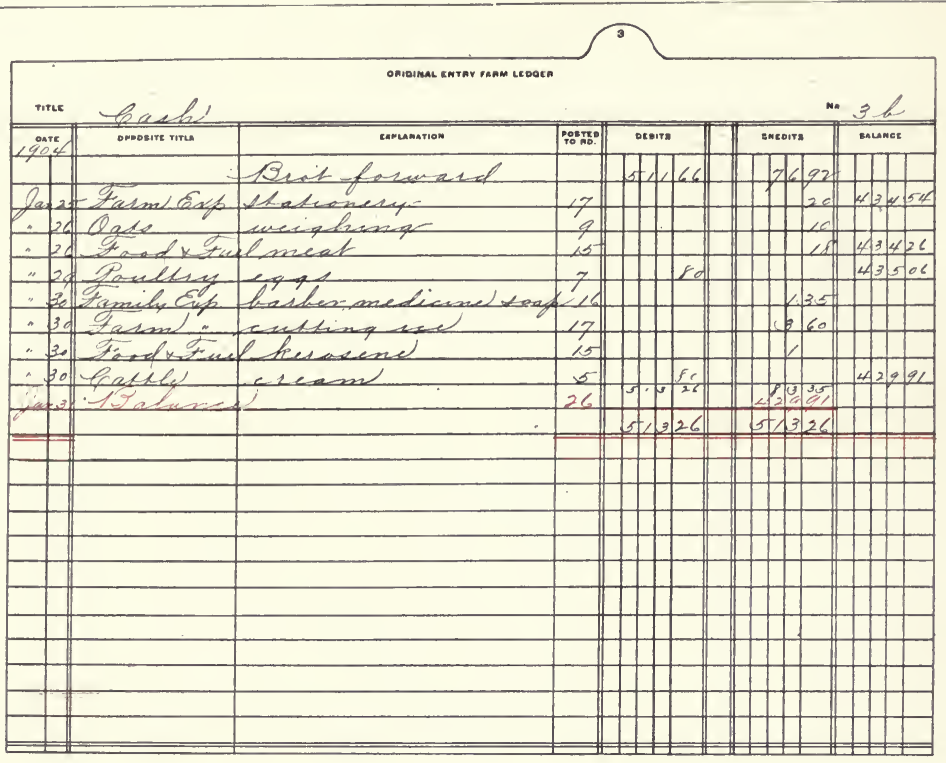

\begin{tabular}{|c|c|c|c|c|c|c|}
\hline \multicolumn{7}{|c|}{ Datiginal Enthy mam leogea } \\
\hline 1404 & Denosite vitue & Exolamation & rosired & oceury & cacoure & malance \\
\hline fand & At lo scleas. & Phomentery caudist & 1 & 680 & & \\
\hline .31 & Labor & man Lameary memors & & s.5. & & \\
\hline$\therefore 31$ & " & (1) & & 7 & 5.3. & \\
\hline$\therefore 31$ & teed & $\Rightarrow \quad 33$ & & $262 \pi$ & A & \\
\hline & -Latanue & (1)nerentaxy-) & 26 & 914 & $2 \times 00$ & \\
\hline $2=\frac{13}{3}$ & Taunlesin & $\angle$ & 25 & 1010 & $2<k 3$ & \\
\hline & & & & $49 \Delta A$ & 49,12 & \\
\hline & & & & & & \\
\hline & & & & & & \\
\hline & & & & & & \\
\hline & & & & & & \\
\hline & & & & & & \\
\hline & & & & & 1 & \\
\hline & & & & & & \\
\hline & & & & & & \\
\hline & & & & & & \\
\hline & & & & & & \\
\hline & & & & & & \\
\hline & & & & & & \\
\hline & & & & & & \\
\hline & & & & & & \\
\hline & & & & & 1 & \\
\hline & & & & & - & \\
\hline
\end{tabular}




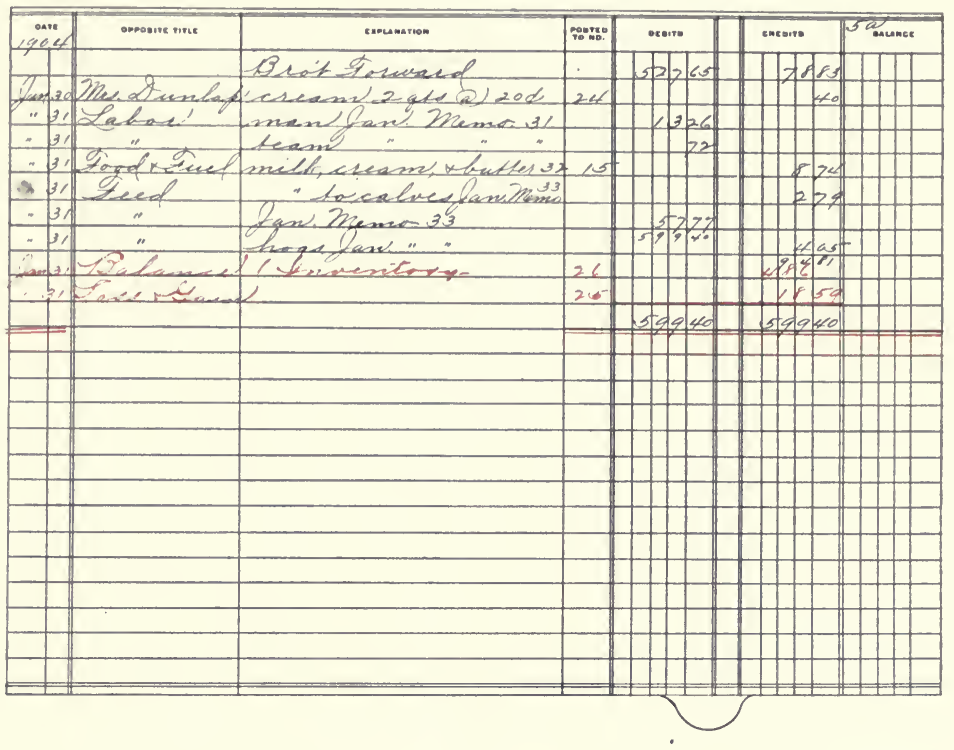

\begin{tabular}{|c|c|c|c|c|c|c|}
\hline rime & Noget & omigimal CNTAY fäm Ledock & & & \multicolumn{2}{|c|}{ m. 6} \\
\hline 1004 & opposire trine & crmcamation & to: & otaire & emsorte & escunce \\
\hline & - L Niblas & 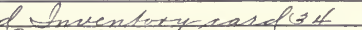 & $\angle$ & $\tan 20$ & & \\
\hline 191 & Labor & Dan hanusy menne il & & 209 & & \\
\hline$\approx \$ 1$ & iteed & 10133 & & 25 & & \\
\hline Thanot & toalanee & (V)incentoxy=1 & 24 & $\sqrt{2}<<$ & $6+2=$ & \\
\hline$\therefore 1 / 2$ & pertetand & & $2-1$ & 11 & 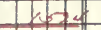 & \\
\hline & & & & 2104 & $218 \mathrm{k}$ & \\
\hline 7 & & & & 11 & 10 & \\
\hline & & ? & & & $\theta$ & \\
\hline & & & & & 1 & \\
\hline & & & & & & \\
\hline & & & & & & \\
\hline & & & & & & \\
\hline & & & & & + & \\
\hline & & & & & & \\
\hline & & & & & & \\
\hline & & & & & H & \\
\hline & & & & & & \\
\hline & & & & & & \\
\hline & & & & & & \\
\hline & & & & & & \\
\hline & & & & & & \\
\hline & & & & & & \\
\hline+ & & & & & 1 & \\
\hline
\end{tabular}

"Gross neglect is equivalent to fraud." 




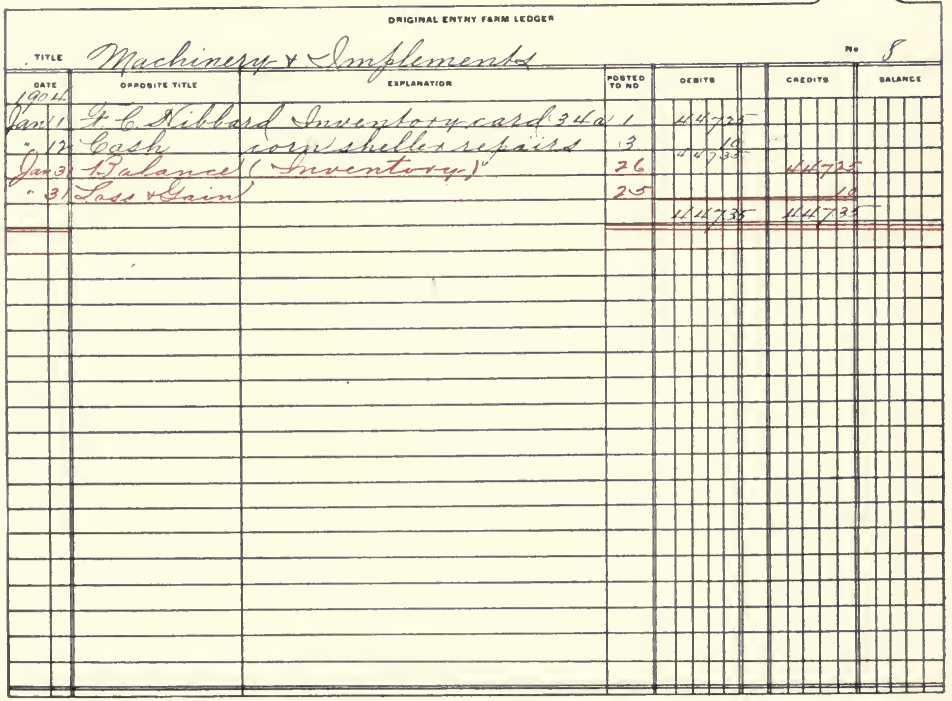

"Think for yourself, if you would become wise." 


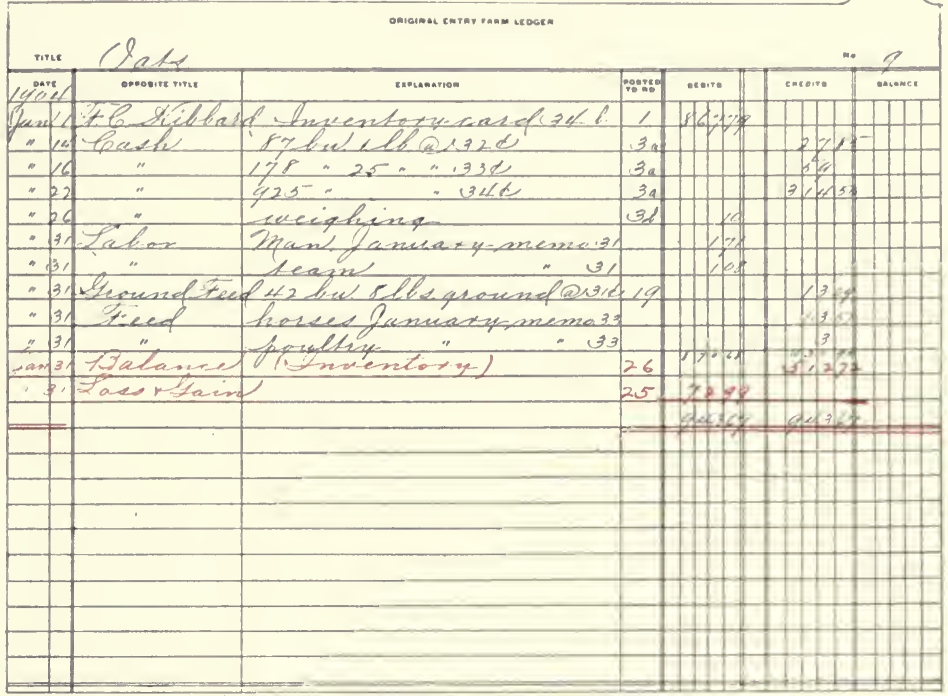

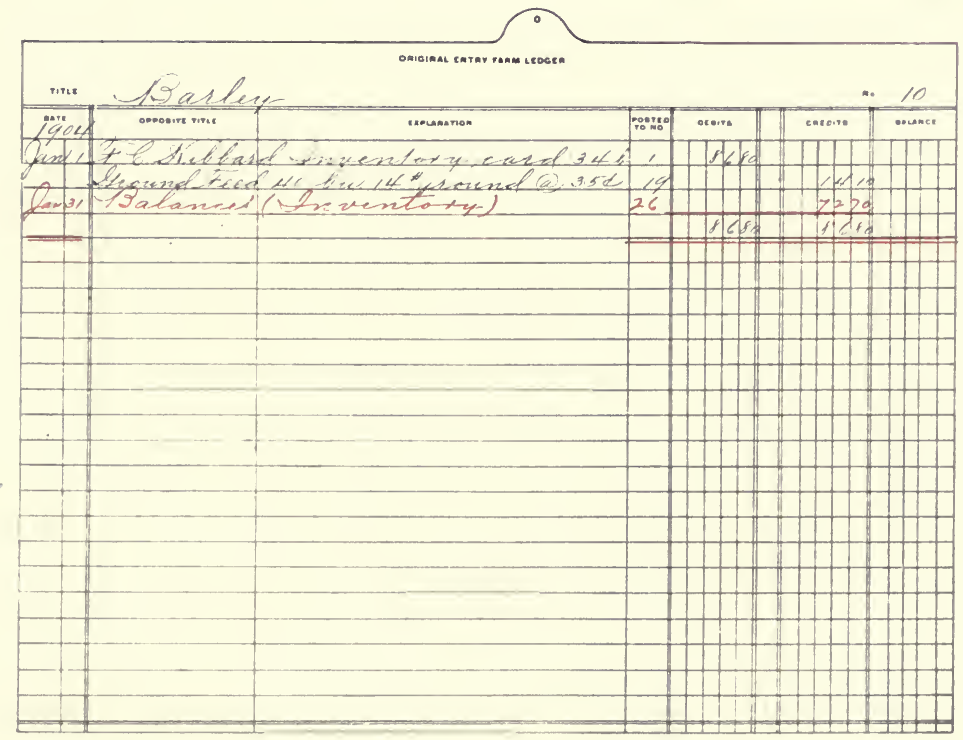

Positive anything is better than negative nothing.-Iubbard. 


\begin{tabular}{|c|c|c|c|c|c|c|}
\hline ritue & lean & 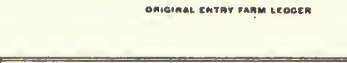 & & & \multicolumn{2}{|c|}{$\cdots / /$} \\
\hline 1904 & oreosits trine & Rarlamation & 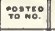 & ocesere & cosoiro & onsumer \\
\hline Cands & A. D. Nibl & ind Inventowreserels & 11 & $221<$ & & \\
\hline 191 & Labor & manllant memo. is & & 6 & & \\
\hline$\because 31$ & $1 "$ & Leahol" " 31 & & 6 & 11 & \\
\hline "31 & teed & cattl" " 33 & & & 270 & \\
\hline$\because 31$ & $\cdot$ & hopes " " 33 & & & $\mid \sqrt{5}$ & 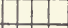 \\
\hline .31 & 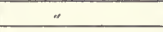 & heoge" " 33 & & & $2<0$ & 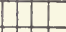 \\
\hline$\because 31$ & 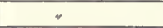 & Hells" " 33 & & & 6 & \\
\hline Tade & Yoralom & Onnemtanes & 26 & 1 & 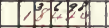 & \\
\hline " & Law relais & L & 2.5 & & 101: & \\
\hline 11 & & & & 2226 & 221265 & 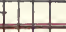 \\
\hline & & & & & & \\
\hline & & & & & & \\
\hline & & & & & 7 & \\
\hline & & & & & & \\
\hline & & & & & & \\
\hline & & & & & 1 & \\
\hline & & & & & & \\
\hline & & & & & & \\
\hline & & & & & & \\
\hline & & & & & & \\
\hline & & & & & & \\
\hline & & $\therefore$ & & & & \\
\hline & . & & & & & \\
\hline
\end{tabular}

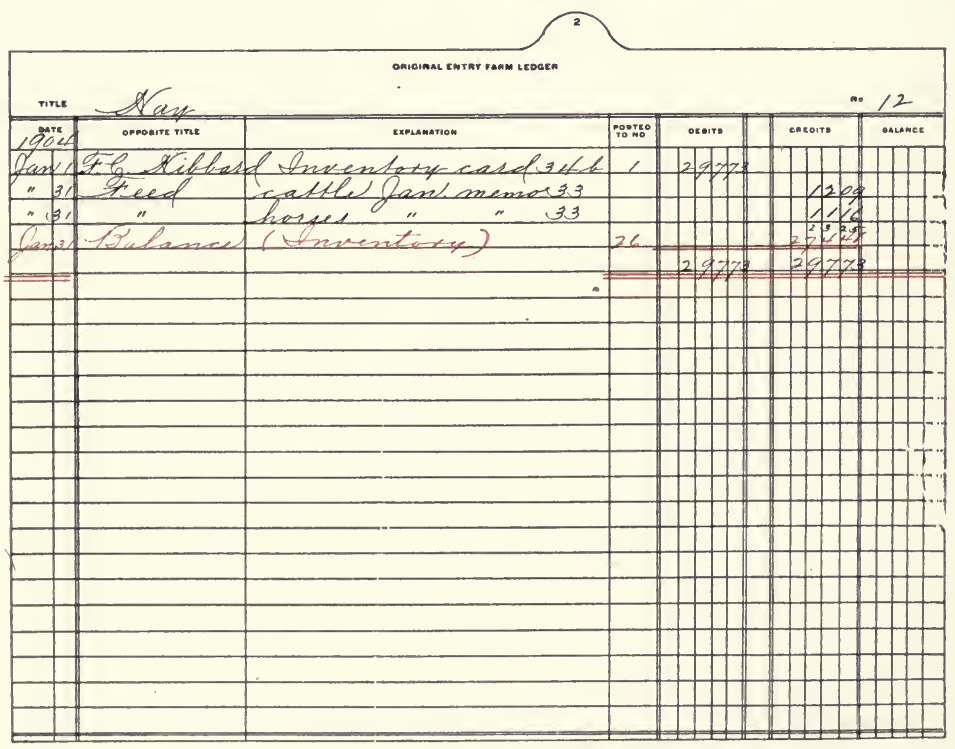

It is just as well to leave a few things unsaid.-Hubbard. 


\begin{tabular}{|c|c|c|c|c|c|c|c|c|}
\hline rirce &  & 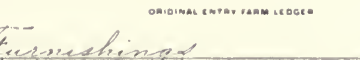 & & & & & no, & 13 \\
\hline 190.4 & enendive pertet & corismanen & $\operatorname{los}_{1000}$ & ocours & & cetenin: & & eacunce \\
\hline $\operatorname{ken}$ & 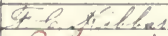 & 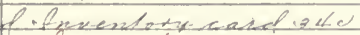 & , & EAC & & & & \\
\hline & Mestanes & (tenventary-1 & 26 & & & 25 & & \\
\hline & & & & 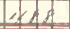 & & efen & & $E$ \\
\hline & & & & & 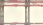 & 17 & 71 & 71 \\
\hline & & & & & & & & \\
\hline & & & & & & & & \\
\hline & & & & & & & & \\
\hline & & & & & & & & \\
\hline & & . & & & & & & \\
\hline & & & & & & & & \\
\hline & & & & & & & & \\
\hline & & & & & & & & \\
\hline & & & & & & & & \\
\hline & & & & & & & & \\
\hline & & & & & & & & \\
\hline & & & & & & & & \\
\hline & & & & & & & & \\
\hline & & & & & & & & \\
\hline & & & & & & & & \\
\hline & & & & & & & & \\
\hline & & & & & & & & \\
\hline & & & & & & & & \\
\hline & & & & 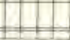 & & 1 & & \\
\hline
\end{tabular}

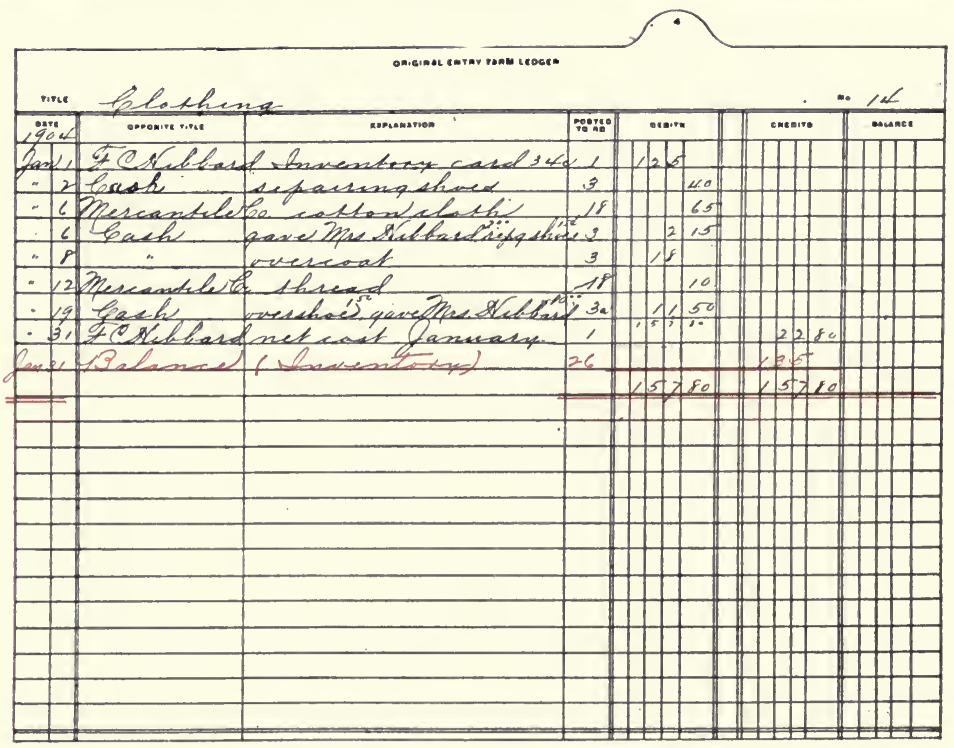

An ounce of performance is worth a pound of promise.-Hubbard. 


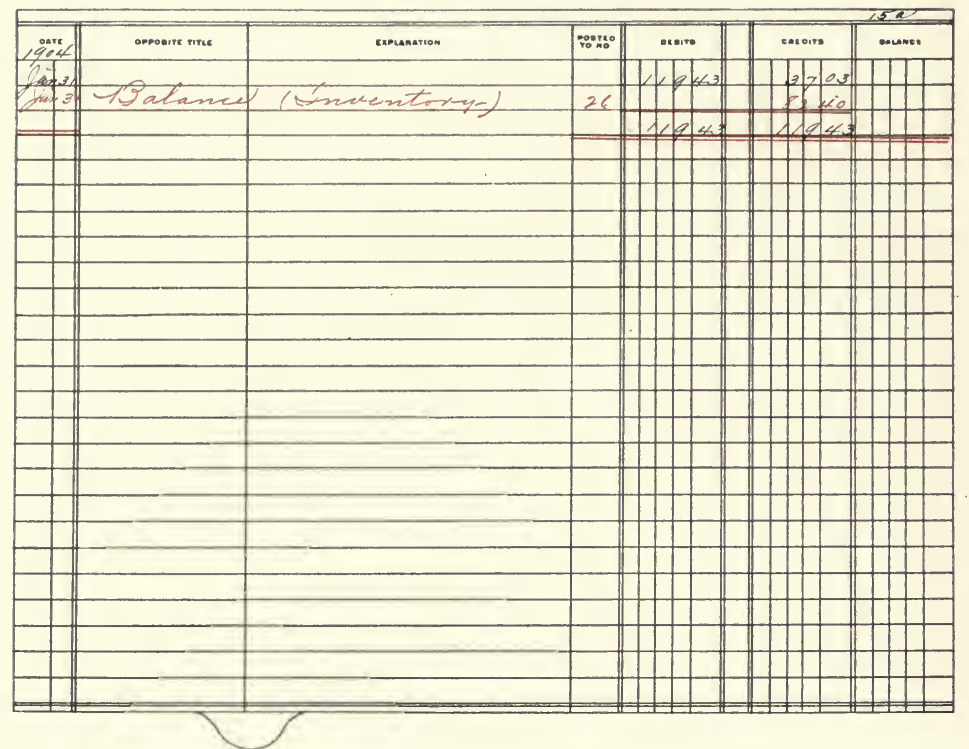

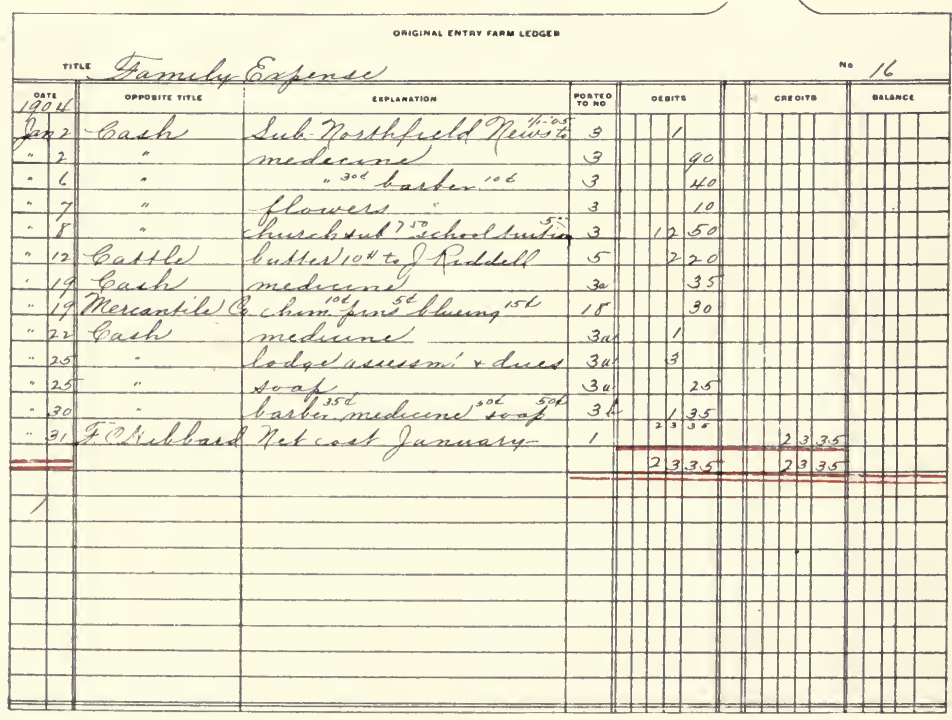

Get hold and hang on and you will succeed.--Ilubbard. 


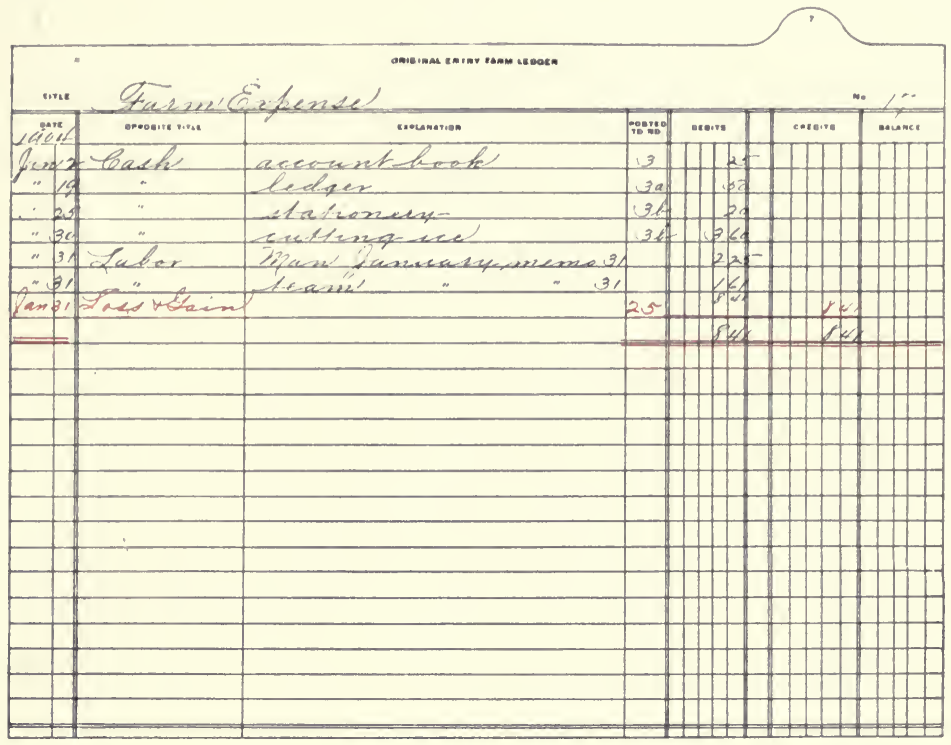

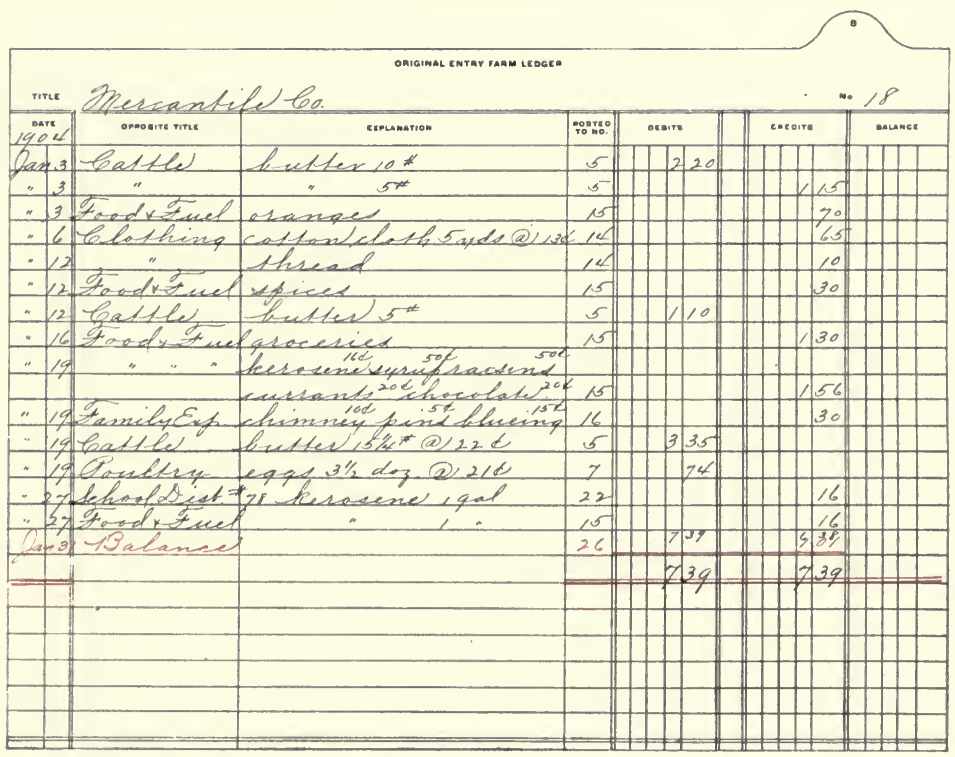

Who accepts from another, sells his freedom.-German. 
FARM ACCOUN'TS.

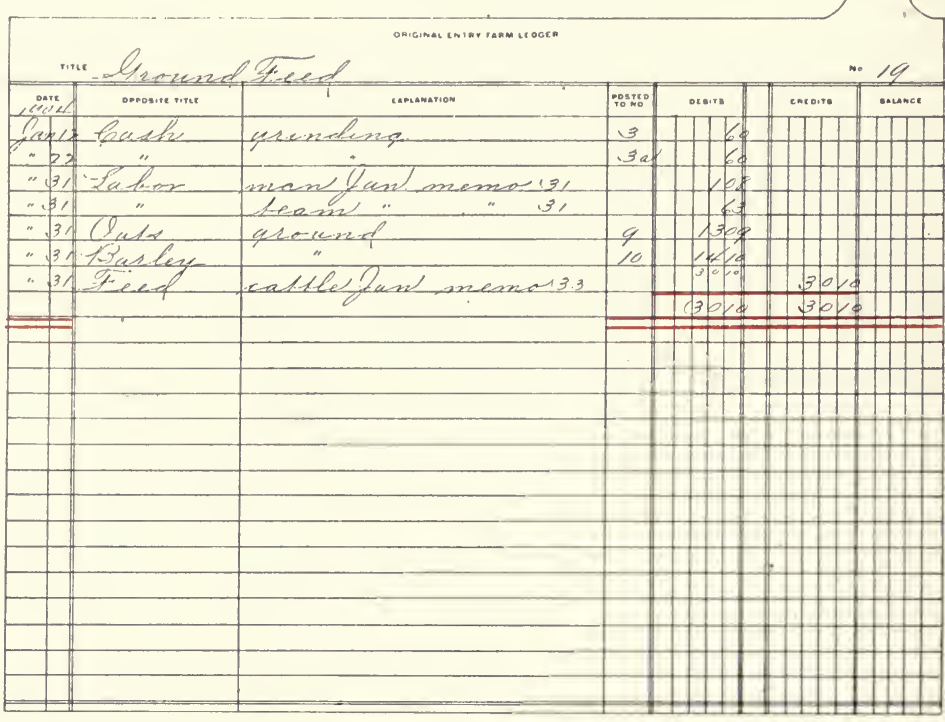

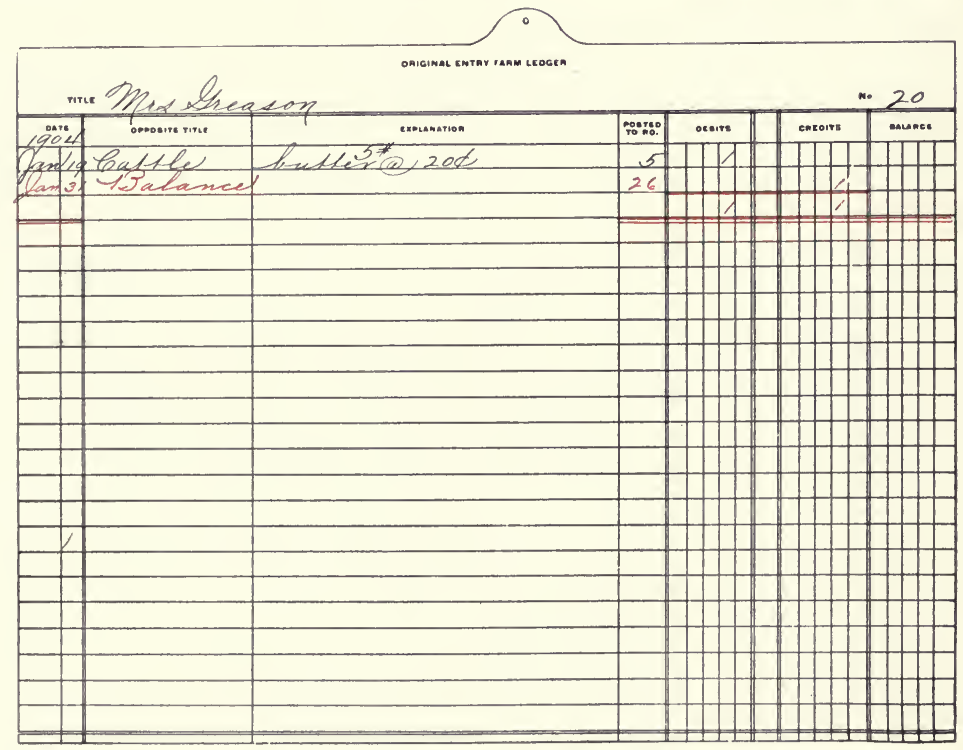

"Not to advance is to recede." 

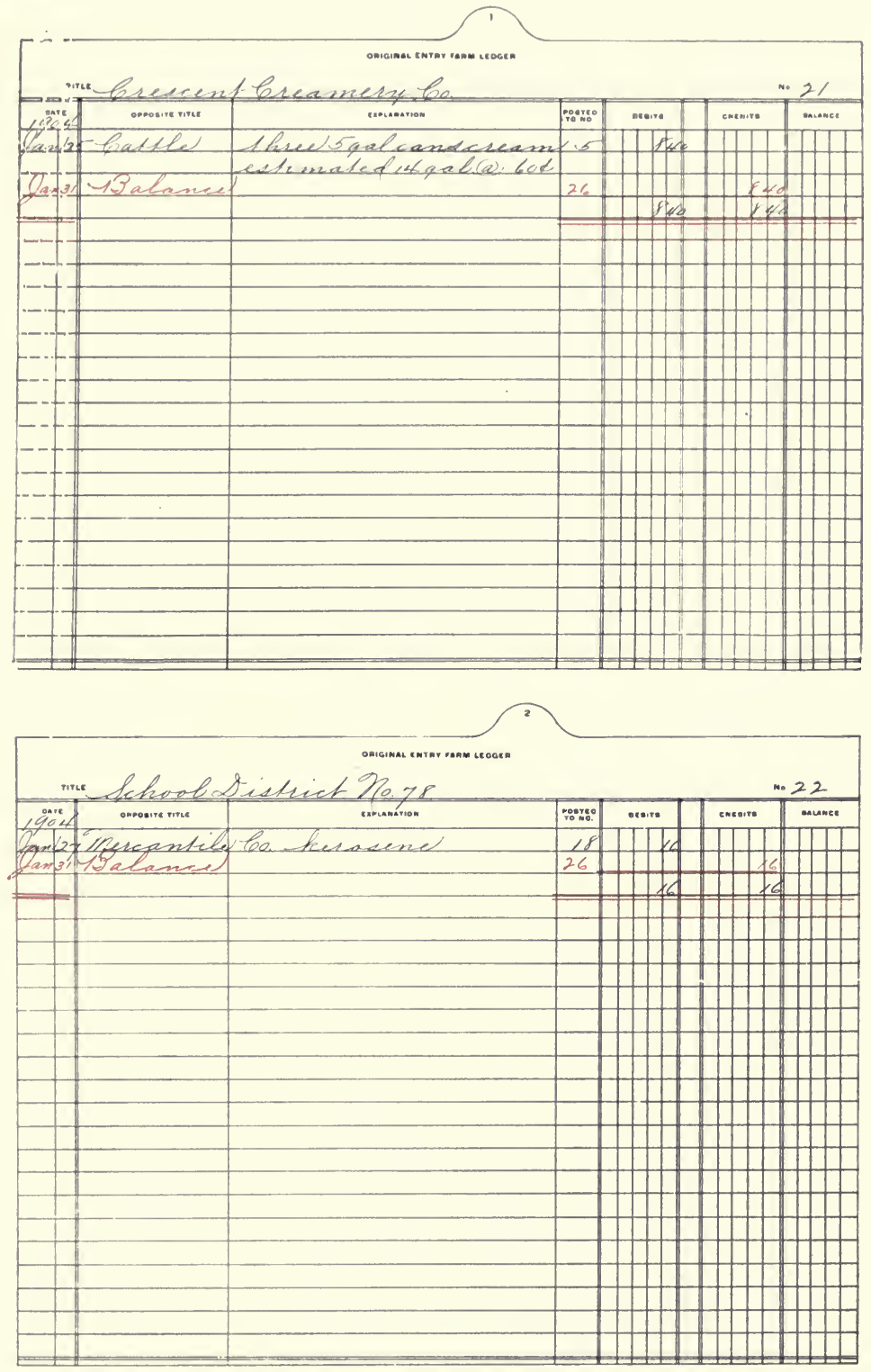

Approve not of him who commends all you say.-Franklin. 
FARM ACCOUNTS.
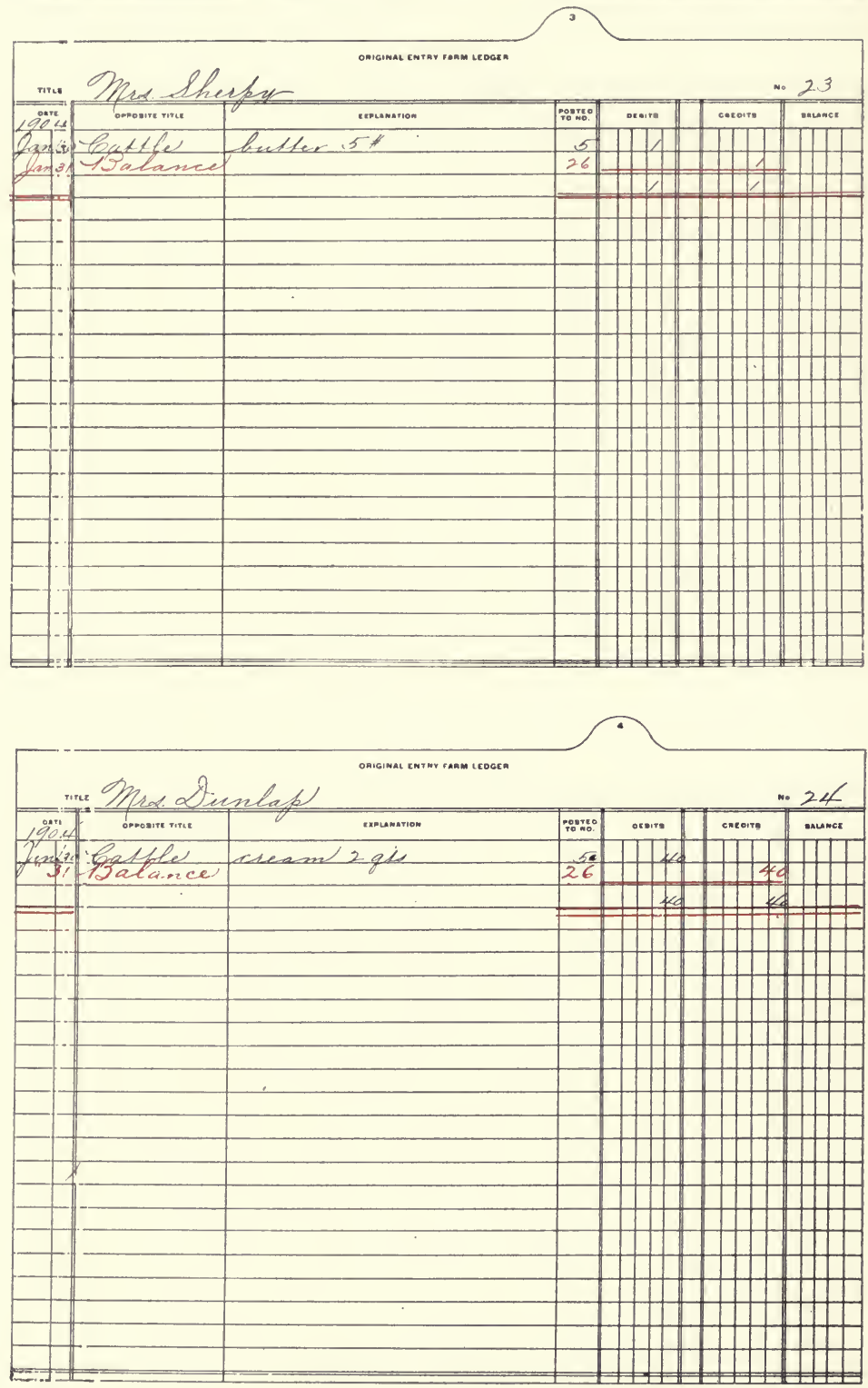

Necessity never made a good bargain.-Franklin. 


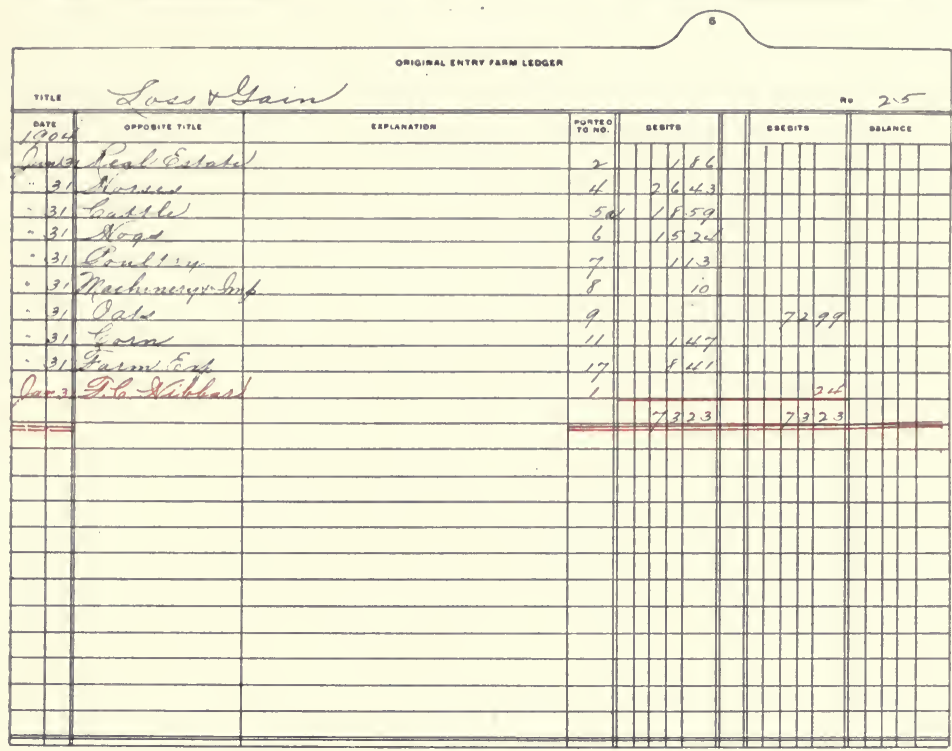

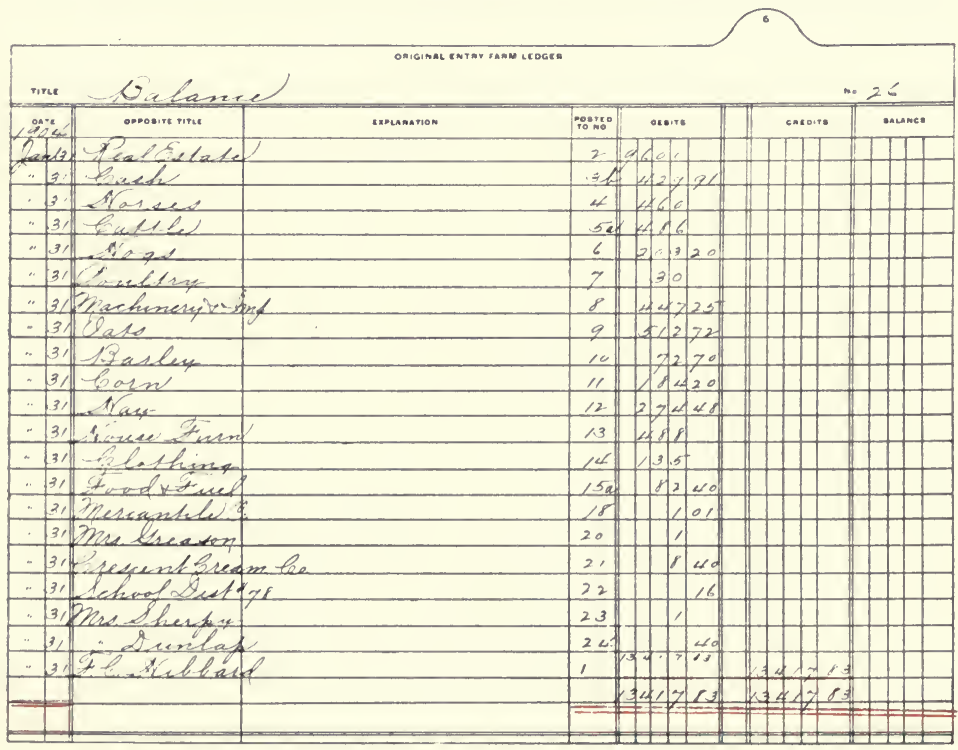

That man is best educated who is most useful.-Hubbard. 


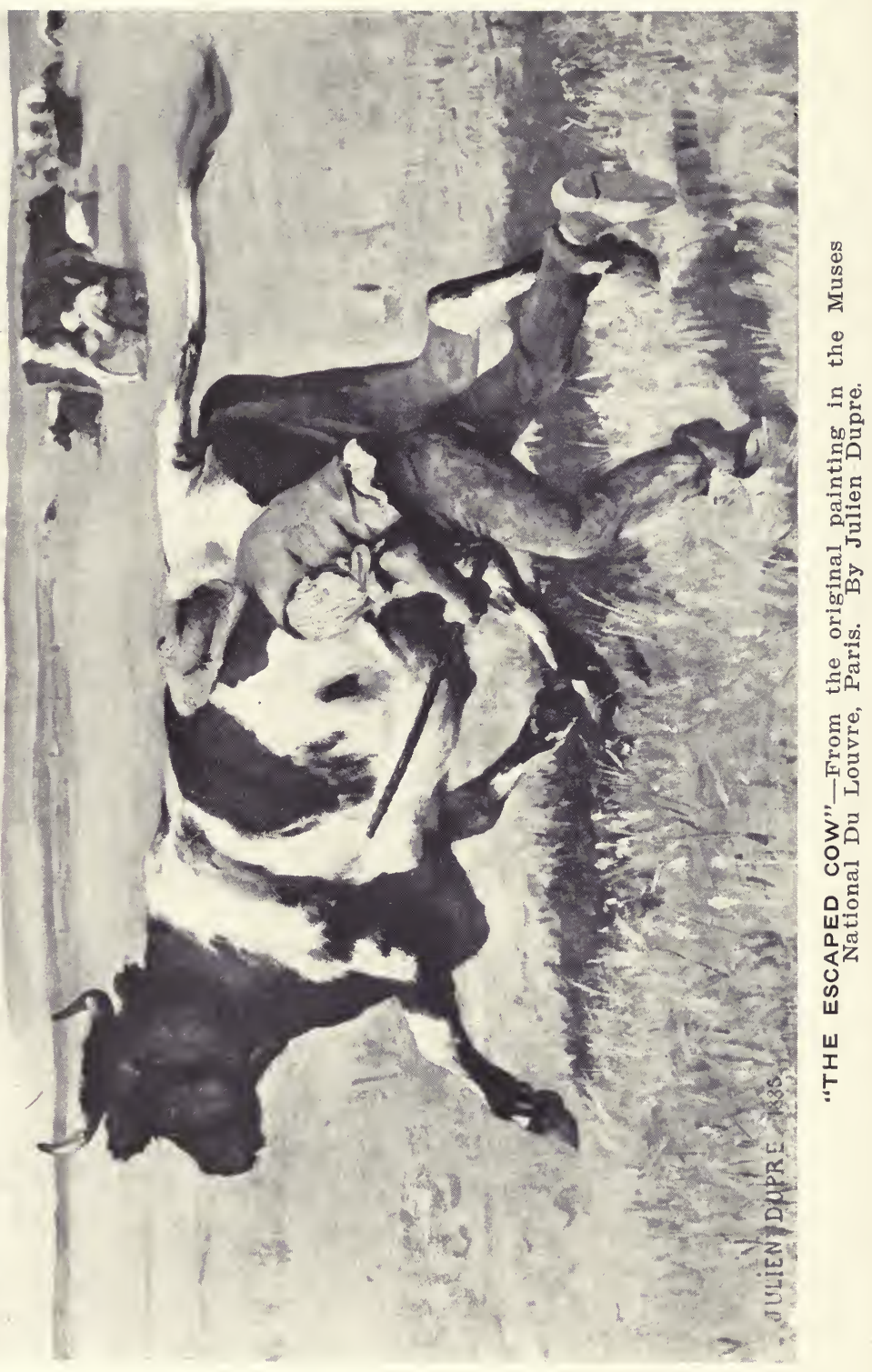




\section{CHAPTER IX.}

\section{PRACTICE WORK.}

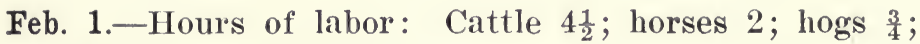
poultry $\frac{1}{3}$....Eggs laid 4 .... Set aside for home use: 1 gallon milk, 1 pint cream.

Feb. 2.-Hours of labor: Cattle $4 \frac{1}{2}$; horses 2; hogs $\frac{3}{4}$; poultry $\frac{1}{3} \ldots$. Eggs laid 1 .... Set aside for home use: 1 gallon milk, 6 eggs.

Feb. 3.-Sold 1 gallon cream $80 \mathrm{c} ; 4 \frac{1}{4}$ pounds butter at $23 \frac{1}{2}$ c.... Hours of labor: Cattle $4 \frac{1}{2}$; horses 2 ; hogs $\frac{3}{4}$; poultry $\frac{1}{3}$; hauling grist for feed 1 man and team 4,2 men $\frac{3}{4}$... Eggs laid 1... Set aside for home use: 1 gallon milk, 3 quarts cream.

Feb. 4.-Hours of labor: Cattle $4 \frac{1}{2}$; horses 2 ; hogs $\frac{3}{4}$; poultry $\frac{1}{3} \ldots$ Eggs laid $4 \ldots$... Set aside for home use: 5 quarts milk, 3 quarts cream, 6 eggs.

Feb. 5.-Paid personal property taxes $\$ 6.51$ (Charge Farm Expense); medicine 50c; binder twine $\$ 22.50$; wood $\$ 8$; kerosene $15 \mathrm{c}$; stationery $27 \mathrm{c} . .$. Bought of Mercantile Co. on account, groceries $50 \mathrm{c} . .$. Sold 81 bushels and 8 pounds of oats at $35 \mathrm{c} ; 5 \frac{1}{2}$ quarts of cream at $20 \mathrm{c} . .$. Hours of labor: Cattle $4 \frac{1}{2}$; horses 2 ; hogs $\frac{3}{4}$; poultry $1 \frac{1}{3}$; marketing oats 1 man and team 3, 2 men $\frac{1}{2} \ldots$ Eggs laid $3 . .$. Set aside for home use: $4 \frac{1}{2}$ quarts milk, 1 pint cream.

Weight of feeds fed to live stock to-day: Cattle-Shredred corn fodder 135 lbs., unshredded corn fodder 139 lbs., hay 129 lbs., ground feed 80 lbs., oats 2 lbs., skim milk 57 lbs.; horses-Hay 119 lbs., oats 46 lbs., corn on cob 11 lbs.; hogs-Corn on cob 209 lbs. and all skim milk and buttermilk not otherwise used; poultry-Corn on cob 10 lbs., oats $11 \mathrm{lbs}$.

The weight of milk given by each cow morning and evening was as follows: Red Heifer, morning 6.9 lbs., evening

Use $72 \mathrm{lbs}$. of corn on the cob to a bushel during February and March.

Troubles grow by recounting them.-Hubbard. 
7.3 lbs.; Nell, morning 11.2 lbs., evening 11.8 lbs.; Black and White Heifer, morning 5 lbs., evening 5.1 lbs.; Crossy, morning 10.9 lbs., evening 10.7 lbs.; Whitey, morning 8.1 lbs., evening 7.9 lbs.; Black and White Cow, morning 8.8 lbs., evening 8.7 lbs.; Durham, morning $9.1 \mathrm{lbs}$. , evening 9.2 lbs.; Dot, molnning 14.6 lbs., evening 14.5 lbs.; Star, morning 5.2 lbs., evening 5.1 lbs.

Took sample of each cow's milk at both milkings today for composite test.

Feb. 6.-Hours of labor: Cattle $4 \frac{1}{2}$; horses 2; hogs $\frac{3}{4}$; poultry $\frac{1}{3} \ldots$ Eggs laid $5 \ldots$... Set aside for home use: $3 \frac{1}{2}$ quarts milk, 4 eggs.

Feb. 7.- Sold 6 pounds. butter at 22c.... Hours of labor: Cattle $4 \frac{1}{2}$; horses 2 ; $\operatorname{logs} \frac{3}{4}$; poultry $\frac{1}{3} \ldots$ Eggs laid 6 .... Set aside for home use: $4 \frac{1}{2}$ quarts milk, 5 pounds butter.

Feb. 8.-Hours of labor: Cattle $4 \frac{1}{2}$; horses 2 ; hogs $\frac{3}{4}$; poultry $\frac{1}{3} \ldots$ Eggs laid $8 \ldots$... Set aside for home use: 1 gallon milk, 5 pounds dressed chicken.

Feb. 9.-Bought flour $\$ 12 \ldots$ Bought of Mercantile Co. on account, sugar $\$ 1 \ldots$ Sold 5 pounds butter at $22 \mathrm{c} . .$. Hours of labor: Cattle $4 \frac{1}{2}$; horses 2 ; hogs $\frac{3}{4}$; poultry $\frac{1}{3}$; hauling wood 1 man and team 4 ... Eggs laid 6 ... Set aside for home use: 1 gallon milk, 1 pint cream.

Feb. 10.-Hours of labor: Cattle $4 \frac{1}{2}$; horses 2 ; hogs $\frac{3}{4}$; poultry $\frac{1}{3}$....Eggs laid 5.... Set aside for home use: 1 gallon milk, 1 pint cream, 10 eggs.

Feb. 11.-Paid subscription to "Farmers' Tribune" to Feb. 1, 1905, $\$ 1$; clothes-line 70c; tie-rope for horses 25c; medicine $10 \mathrm{c} . .$. Sold 5 pounds butter at $22 \mathrm{c} ; 4 \frac{3}{4}$ quarts cream at 20c...Hours of labor: Cattle $4 \frac{1}{2}$; horses 2 ; hogs $\frac{3}{4}$; poultry $\frac{1}{3} \ldots$ Eggs laid $4 \ldots$. Set aside for home use : 3 quarts milk, 4 quarts cream.

Feb. 12.-Paid A. O. U. W. assessment $\$ 1 \ldots$ Bought of Mercantile Co. on account, groceries $40 \mathrm{c}$; overalls $50 \mathrm{c} . .$. Sold Mercantile Co. on account, 5 pounds butter at 22c... Hours of labor: Cattle $4 \frac{1}{2}$; horses 2 ; hogs $\frac{3}{4}$; poultry $\frac{1}{3} \ldots$

"What are you? Not what you have been." 
Eggs laid 6.... Set aside for home use: 1 gallon milk.

Feb. 13.-Bought oyster shells for poultry 25c; shoe repairs $15 \mathrm{c} . .$. Sold 5 lbs. butter at $25 \mathrm{c} ; 3$ quarts cream at 20c.... Gave to Mrs. Riddell $11 \frac{1}{2}$ lbs. butter valued at 22c. per pound....Hours of labor: Cattle $4 \frac{1}{2}$; horses 2 ; hogs $\frac{3}{4}$; poultry $\frac{1}{3}$....Eggs laid $8 \ldots$... Set aside for home use: 1 gallon milk, 1 pint cream.

Feb. 14.-Hours of labor: Cattle $4 \frac{1}{2}$; horses 2 ; hogs $\frac{3}{4}$; poultry $\frac{1}{3} \ldots$ Eggs laid 8 .... Set aside for home use: 5 pounds butter, 5 quarts milk, 1 pint cream, 4 eggs.

Feb. 15.-Hours of labor: Cattle $4 \frac{1}{2}$; horses 2 ; hog $\frac{3}{4}$; poultry $\frac{1}{3} \ldots$... Egs laid $12 \ldots$. Set aside for home use : 1 gallon milk, 1 quart cream, $4 \frac{1}{2}$ pounds dressed chicken.

Weight of feeds fed to live stock to-day: Cattle-Shredded corn fodder 134 lbs., unshredded corn fodder 141 lbs., hay 130 lbs., ground feed 62 lbs., oats 2 lbs., skim milk 57 lbs.; horses-Hay 121 lbs, oats 46 lbs., corn on cob 11 lbs.; hogs-Corn on cob $211 \mathrm{lbs}$. and all skim milk and buttermilk not otherwise used; poultry-Corn on cob 10 lbs., oats 10 lbs.

The weight of milk given by each cow, morning and evening, was as follows: Red Heifer, morning 7 lbs., evening 7.2 lbs.; Nell, morning 11.5 lbs., evening 11.9 lbs.; Black and White Heifer, morning 4.9 lbs., evening 4.9 lbs.; Crossy, morning 10.6 lbs., evening 10.8 lbs.; Whitey, morning 7.3 lbs., evening 7.2 lbs.; Black and White Cow, morning 8.5 lbs., evening 8.6 lbs.; Durham, morning 9.3 lbs., evening 9.2 lbs.; Dot, morning 14.6 lbs., evening 14.7 lbs.; Star, morning $4.9 \mathrm{lbs}$, evening $4.7 \mathrm{lbs}$.

Took sample of each cow's milk at both milkings to-day for composite test.

Feb. 16.- Sold 5 pounds butter at 23c.... Sold Mercantile Co. on account, $16 \frac{1}{4}$ pounds butter at $20 \mathrm{c}$... Hours of labor : Cattle $4 \frac{1}{2}$; horses 2 ; hogs $\frac{3}{4}$; poultry $\frac{1}{3}$; sacking oats for market 2 men $\frac{1}{2}$; sacking barley for grist 2 men $\frac{1}{2} \ldots$ Eggs laid $14 \ldots$ Set aside for home use: $4 \frac{1}{2}$ quarts milk, 1 pint cream, 10 eggs.

The world treats you as well as you treat it.-Hubbard. 
Feb. 17.-Paid sleigh repairs 50c; saw filing 60c; oil meal for cattle $\$ 1.65$; grinding feed $60 \mathrm{c}$; postal cards $24 \mathrm{c}$ ....Bought of Mercantile Co. on account, groceries $\$ 1.90$; lamp chimney 10c.... Sold 95 bushels oats at 35̃....Hours of labor: Cattle $4 \frac{1}{2}$; horses 2 ; hogs $\frac{3}{4}$; poultry $\frac{1}{3}$; hauling grist 1 man and team 3... Eggs laid $10 \ldots$ Set aside for home use: $4 \frac{3}{4}$ quarts milk, 3 quarts cream.

Feb. 18.-Paid for 1 pair stockings 25c; Degree of Honor assessment $\$ 2$....Bought of Mercantile Co. on account, 1 broom 35c.... Sold to Mercantile Co. on account, 10 pounds butter at $22 \mathrm{c} .$. . Sold 11 bushels barley at $42 \frac{3}{4} \mathrm{c} \ldots$. . Hours of labor: Cattle $4 \frac{1}{2}$; horses 2 ; hogs $\frac{3}{4}$; poultry $\frac{1}{3} \ldots$... Eggs laid $14 \ldots$. Set aside for home use: 1 gallon milk, 1 pint cream.

Feb. 19.-Bought wood $\$ 4.50 \ldots$. . Bought of Mercantile Co. on account, crackers $25 \mathrm{c}$; cloth and ribbons $\$ 1.43 \ldots$ Hours of labor: Cattle $4 \frac{1}{2}$; horses 2 ; hogs $\frac{3}{4}$; poultry $\frac{1}{3}$; cutting wood 1 man $\frac{1}{2} \ldots$ Eggs laid $8 \ldots$... Set aside for home use: $4 \frac{1}{2}$ quarts milk, 1 pint cream, 8 eggs.

Feb. 20.-Bought wood $\$ 4.50$; medicine $15 \mathrm{c} . .$. Bought of Mercantile Co. on account, kerosene and oranges 54c .... Sold 1 gallon cream at 80c....Hours of labor: Cattle $4 \frac{1}{2}$; horses 2 ; hogs $\frac{3}{4}$; poultry $\frac{1}{3}$; hauling wood 1 man and team 3, cutting wood 1 man 1 .... Eggs laid $12 \ldots$. Set aside for home use: 1 galion milk, 1 quart cream.

Feb. 21.-Paid subscription to "American Boy," to February, $1905, \$ 1 \ldots$ Hours of labor: Cattle $4 \frac{1}{2}$; horses 2 ; hogs $\frac{3}{4}$; poultry $\frac{1}{3} \ldots$ Eggs laid $15 \ldots$... Set aside for home use: 5 pounds of butter, $4 \frac{1}{2}$ quarts milk, 1 pint of cream... Sold 5 doz. eggs at $25 \mathrm{c}$.

Feb. 22.-Sold 4 dozen eggs at 25c....Bought medicine $55 \mathrm{c}$; lemons $10 \mathrm{c}$; candy $5 \mathrm{c} . .$. Hours of labor: Cattle $4 \frac{1}{2}$; horses 2 ; hogs $\frac{3}{4}$; poultry $\frac{1}{3} \ldots$... Eggs laid $14 \ldots$... Set aside for home use: $4 \frac{1}{2}$ quarts milk, 1 pint cream, $8 \frac{3}{4}$ pounds dressed chicken, 8 eggs.

"You must be dead to many things, if you would rise." 
Feb. 23.-Hours of labor: Cattle $4 \frac{1}{2}$; horses 2 ; hogs $\frac{3}{4}$; poultry $\frac{1}{3} \ldots$ Eggs laid $10 \ldots$ set aside for home use: $6 \frac{1}{2}$ quarts milk, 1 quart cream.

Feb. 24.-Sold to Mercantile Co. on account, 10 pounds butter at $22 \mathrm{c} . .$. Sold to Mrs. Bixby 5 pounds butter at $22 \mathrm{c}$. She paid $\$ 1$, balance to be charged to her account... Bought of Mercantile Co. on account, crackers $60 \mathrm{c} . .$. Hours of labor: Cattle $4 \frac{1}{2}$; horses 2 ; hogs $\frac{3}{4}$; poultry $\frac{1}{3}$; cutting wood 1 man $2 \ldots$ Eggs laid $12 \ldots$. Set aside for home use: $4 \frac{1}{2}$ quarts milk, 1 pint cream.

Feb. 25.-Hours of labor: Cattle $4 \frac{1}{2}$; horses 2 ; hogs $\frac{3}{4}$; poultry $\frac{1}{3} \ldots$ Eggs laid $10 \ldots$... Set aside for home use: $4 \frac{1}{4}$ quarts milk, 10 eggs.

Weight of feeds fed to live stock to-day: Cattle--Shredded corn fodder 136 lbs., unshredded corn fodder 140 lbs., hay $131 \mathrm{lbs}$., ground feed $62 \mathrm{lbs}$. , oats $2 \mathrm{lbs}$., skim milk 57 lbs.; horses-Hay 120 lbs., corn on cob 11 lbs., oats 46 lbs.; hogs-Corn on cob 210 lbs. and all skim milk and buttermilk not otherwise used; poultry--Corn on cob $10 \mathrm{lbs}$., oats $12 \mathrm{lbs}$.

The weight of milk given by each cow, morning and evening, was as follows: Red Heifer, morning 6.8 lbs., evening 6.5 lbs.; Nell, morning 11.3 lbs., evening 10.7 lbs.; Black and White Heifer, morning $4.5 \mathrm{lbs}$., evening $4.4 \mathrm{lbs}$.; Crossy, morning 10.5 lbs., evening 10.4 lbs.; Whitey, morning 6.9 lbs., evening 7 lbs., Black and White Cow, morning 8.7 lbs., evening, 8.6 lbs.; Durham, morning $9.1 \mathrm{lbs}$., evening $9.3 \mathrm{lbs}$.; Dot, morning 14.5 lbs., evening 14.4 lbs.; Star, morning 4.8 lbs., evening $4.4 \mathrm{lbs}$.

Took sample of each cow's milk at both milkings to-day for composite test.

Feb. 26.-Hours of labor: Cattle $4 \frac{1}{2}$; horses 2; hogs $\frac{3}{4}$; poultry $\frac{1}{3} \ldots$ Eggs laid $10 \ldots$... Set aside for home use: 1 gallon milk, 1 quart cream.

Fashion is a barricade behind which people hide their nothingness. -Hubbard. 
A test was made to-day of the composite samples of each cow's milk taken on the 5th, 15th and 25th of the month. This test shows that the per cent of butter fat contained in each cow's milk was as follows: Red Heifer 3.8; Nell 3.8; Black and White Heifer 4; Crossy 3.6; Whitey 3.8; Black and White Cow 4.2; Durham 3.8; Dot 3.9; Star 4.1.

Cream from this morning's skimming tested 25 per cent butter fat.

Feb. 27.-Bought medicine $\$ 2 \ldots$ Bought of Mercantile Co. on account, sorghum and sugar $\$ 1.50 \ldots$ Sold Mercantile Co. on account, 10 pounds butter at $22 \mathrm{c} . .$. Sold $1 \frac{1}{4}$ quarts cream at 20c....Hours of labor: Cattle $4 \frac{1}{2}$; horses 2 ; hogs $\frac{3}{4}$; poultry $\frac{1}{3} \ldots$ Eggs laid $10 \ldots$. Set aside for home use: 1 gallon milk, 1 pint cream.

Feb. 28.-Bought books and stationery 75c; medicine $25 \mathrm{c} . .$. Hours of labor: Cattle $4 \frac{1}{2}$; horses 2 ; hogs $\frac{3}{4}$; poultry $\frac{1}{3} \ldots$ Eggs laid $11 \ldots$... Set aside for home use: $4 \frac{1}{2}$ quarts milk, 1 pint cream.

Feb. 29.-Sold 10 bushels 18 pounds oats at $33 \frac{1}{2} \mathrm{c} ; 2$ bushels 8 pounds ear corn at $52 \mathrm{c} ; 303$ pounds hay at $\$ 6$ per ton... Received for board of F. B. Headley $\$ 11.50 \ldots$. . Sold 4 doz. eggs at $25 \mathrm{c} . .$. Hours of labor : Cattle $4 \frac{1}{2}$; horses 2 ; hogs $\frac{3}{4}$; poultry $1 \frac{1}{3} \ldots$ Eggs laid $3 \ldots$.... Set aside for home use: 5 pounds of butter, $4 \frac{1}{2}$ quarts milk, 1 pint cream, 7 eggs.

The rate of wages during the month is $\$ 18$ per month and board. The board is figured at $\$ 2.50$ per week.

The prices of feeds and products used during the month are as follows: Corn fodder $\$ 3$ per ton; hay $\$ 7$ per ton; oats $36 \mathrm{c}$ per bushel; corn 35c per bushel; barley 36c per bushel; whole milk $\$ 1$ per hundred; skim milk 15c per hundred; cream $80 \mathrm{c}$ per gallon; butter 22c per pound; eggs 25c per dozen; dressed chicken 8c per pound.

Reference should be made to the explanations and illustrations in January for guidance in calculating and recording the values on the auxiliary cards.

Creditors have better memories than debtors.-Franklin. 
Mar. 1.-Paid for medicine 25c....Bought of Mercantile Co. on account, cream of wheat $15 \mathrm{c}$; underclothing $\$ 1.70$; baking powder $40 \mathrm{c} . .$. Sold Mercantile Co. on account, $15 \mathrm{lbs}$. butter at $22 \mathrm{c} \ldots$ Hours of labor: Cattle $4 \frac{1}{2}$; horses 2 ; hogs $\frac{3}{4}$; poultry $\frac{1}{3} \ldots$ Eggs laid $12 \ldots$. . Set aside for home use: $1 \frac{1}{8}$ gallons milk, 3 pints cream, 5 eggs.

Mar. 2.-Paid for grinding feed 60c...Hours of labor: Cattle $4 \frac{1}{2}$; horses 2 ; hogs $\frac{3}{4}$; poultry $\frac{1}{3} \ldots$ Eggs laid $8 . .$. Set aside for home use: $1 \frac{1}{8}$ gallons milk.

Mar. 3.-Paid for nutmegs 10c; barber 10c....Hours of labor: Cattle $4 \frac{1}{2}$; horses 2 ; hogs $\frac{3}{4}$; poultry $\frac{1}{3} \ldots$... Eggs laid 11.... Set aside for home use: $1 \frac{5}{8}$ gallons milk, 1 pint cream, 6 eggs, 4 pounds butter.

Mar. 4.-Hours of labor: Cattle $4 \frac{1}{2}$; horses 2 ; hogs $\frac{3}{4}$; poultry $\frac{1}{3} \ldots$ Eggs laid $11 \ldots$... Set aside for home use: $1 \frac{1}{4}$ gallons milk, 1 pint cream.

Mar. 5.-Paid postage $10 \mathrm{c}$; medicine $\$ 2.95$; pail for house $45 c . .$. Bought of Mercantile Co. on account, "soap 25c; yeast $5 \mathrm{c}$; oranges $30 \mathrm{c}$; rubbers and overalls $\$ 1.35$; gloves 20c... Sold Mercantile Co. on account, $10 \mathrm{lbs}$. butter at $22 \mathrm{c}$ .... Sold to M. G. Hibbard on account, $1 \mathrm{lb}$. butter 20c... Hours of labor: Cattle $4 \frac{1}{2}$; horses 2 ; hogs $\frac{3}{4}$; poultry $\frac{1}{3}$; †churning 1 man 1, 1 woman $\frac{3}{4}$; hauling manure to corn land 2 men and team 3....Eggs laid $11 . .$. Set aside for home use: $1 \frac{1}{2}$ gallons milk, 1 pint cream, 4 eggs.

Weight of feeds fed to live stock to-day: Cattle-Corn fodder 134 lbs., hay 33 lbs., ground feed 74 lbs., skim milk 65 lbs.; horses-Hay 145 lbs., oats 60 lbs.; hogs-Corn on cob $120 \mathrm{lbs}$. and all skim milk and buttermilk not otherwise used; poultry-Oats 14 lbs., corn on cob 4 lbs.

The weight of milk given by each cow, morning and evening, was as follows: Red Heifer, morning 6.3 lbs., evening 6.2 lbs.; Nell, morning 9.6 lbs., evening 9.3 lbs.; Black and White Heifer, morning 4 lbs., evening 3.9 lbs.; Crossy, morn.

*Unless otherwise specified charge soap to Family Expense. tEnter under Man Labor. 
ing 10.2 lbs., evening 10.3 lbs.; Whitey, morning 6.5 lbs., evening 6.3 lbs.; Black and White Cow, morning 8.1 lbs., evening 7.9 lbs.; Durham, morning 8.5 lbs., evening 8.4 lbs.; Dot, morning 13.3 lbs., evening, 13.4 lbs.; Star, morning 4 lbs., evening 3.8 lbs.; Holstein, morning 16.8 lbs., evening $17.3 \mathrm{lbs}$.

Took sample of each cow's milk at both milkings to-day for composite test. Holstein's milk used to-day for first time since birth of calf on the $2 d$.

Mar. 6.-Hours of labor: Cattle $4 \frac{1}{2}$; horses 2 ; hogs $\frac{3}{4}$; poultry $\frac{1}{3} \ldots$ Eggs laid $13 \ldots$.... Set aside for home use: $1 \frac{1}{2}$ gallons milk, 1 pint cream.

Mar. 7.-Paid for medicine $50 \mathrm{c} . .$. Bought of Mercantile Co. on account, cloth and laces $\$ 1$; rubbers $55 \mathrm{c}$; tea, salt and kerosene $\$ 1.50 \ldots$... Sold Mercantile Co. on account, 5 Ibs. butter at $22 \mathrm{c} . .$. Hours of labor: Cattle $4 \frac{1}{2}$; horses 2 ; hogs $\frac{3}{4}$; poultry $\frac{1}{3}$; hauling manure to corn land 1 man and team $5 \frac{1}{2} \ldots$ Eggs laid $17 \ldots$. Set aside for home use: $1 \frac{3}{4}$ gallons milk, 1 pint cream, 8 eggs.

Mar. 8.-Hours of labor: Cattle $4 \frac{1}{2}$; horses 2 ; hogs $\frac{3}{4}$; poultry $\frac{1}{3}$; hauling manure to corn land 1 man and team $2 \frac{3}{4}$; hauling manure for apple trees 2 men and team $1 \frac{1}{2}$ (Charge Farm Expense); hauling wood 1 man and team 3; churning 1 man 1 and 1 woman $\frac{1}{2} \ldots$... Eggs laid $16 \ldots$. Set aside for home use: $1 \frac{1}{2}$ gallons milk, $5 \frac{1}{2}$ pounds dressed chicken, 3 eggs.

Mar. 9.-Paid for cheese $38 \mathrm{c}$; bananas $15 \mathrm{c}$; filing saw $25 \mathrm{c}$ (Charge Machinery and Implements); hair cut 20c; caps $75 \mathrm{c}$ .... Sold Mrs. Sherpy 5 lbs. butter at 22c. She paid $\$ 1$, the balance to be charged to her account....Hours of labor: Cattle $4 \frac{1}{2}$; horses 2 ; hogs $\frac{3}{4}$; poultry $\frac{1}{3}$; cutting wood 1 man 1....Eggs laid 25.... Set aside for home use: $1 \frac{1}{2}$ gallons milk, 1 pint cream.

Mar. 10.-Paid for clothing $\$ 4$; medicine $15 \mathrm{c}$; postage 10c: railroad fare and expenses of John Hibbard to Faribault and return $\$ 2.10 \ldots$ Bought of Mercantile Co. on

"Read much, but not too many books." 
account, breakfast food $15 \mathrm{c}$; thread $25 \mathrm{c}$; umbrella $\$ 1 . .$. Sold to Mercantile Co on account, 5 lbs. butter at $22 \mathrm{c} . .$. Hours of labor: Cattle $4 \frac{1}{2}$; horses 2 ; hogs $\frac{3}{4}$; poultry $\frac{1}{3} \ldots$. . Eggs laid 21... Set aside for home use: $1 \frac{1}{4}$ gallons milk, 1 pint cream, 5 pounds butter.

Mar. 11.-Hours of labor: Cattle $4 \frac{1}{2}$; horses 2 ; hogs $\frac{3}{4}$; poultry $\frac{1}{3}$; hauliug manure to corn land 1 man and team $3 \frac{1}{2}$; churning 1 man $\frac{3}{4}, 1$ woman $\frac{1}{2} \ldots$. Eggs laid $22 \ldots$. Set aside for home use: $1 \frac{1}{2}$ gallons milk, 3 pints cream, 5 eggs, 4 pounds dressed chicken.

Mar. 12.-Paid for bananas $15 \mathrm{c} . .$. Sold $\frac{1}{2}$ gallon cream at $80 \mathrm{c} . .$. Hours of labor: Cattle $4 \frac{1}{2}$; horses 2 ; hogs $\frac{3}{4}$; poultry $\frac{1}{3}$; cutting wood 1 man $2 \frac{1}{2}$; churning 1 man $\frac{1}{2}, 1$ woman $\frac{1}{2} \ldots$ Eggs laid $25 \ldots$. Set aside for home use: $1 \frac{1}{8}$ gallons milk, 1 pint cream, 6 eggs.

Mar. 13.-Hours of labor: Cattle $4 \frac{1}{2}$; horses 2 ; hogs $\frac{3}{4}$; poultry $\frac{1}{3} \ldots$ Eggs laid $26 \ldots$ Set aside for home use: $1 \frac{1}{8}$ gallons milk, 1 pint cream, 6 eggs.

Mar. 14.-Paid for medicine $\$ 3.35$; fish $30 \mathrm{c}$; thread and cloth $\$ 1.54$; oil meal for cattle $90 \mathrm{c}$. . Received cash from $\mathrm{F}$. B. Headley for $149 \mathrm{lbs}$. corn on cob at 35c per bu.; 84 lbs. oats at $36 \mathrm{c}$ per bu.; $144 \mathrm{lbs}$. hay at $\$ 6$ per ton... Hours of labor : Cattle $4 \frac{1}{2}$; horses 2 ; $\operatorname{logs} \frac{3}{4}$; poultry $\frac{1}{3}$; hauling manure to corn land 1 man and team $2 \frac{1}{2}$; churning 1 woman $1 \frac{1}{2} \ldots$ Eggs laid 23.... Set aside for home use: $1 \frac{3}{8}$ gallons milk, 1 pint cream.

Mar. 15.-Paid for medicine dropper 5c; weighing hogs $20 \mathrm{c}$; barber $35 \mathrm{c}$; nurse for care of daughter 11 days at $\$ 3$ .... Sold 2,695 lbs. hogs at $\$ 3.05 \ldots$ Hours of labor: Cat. tle $4 \frac{1}{2}$; horses 2 ; hogs $\frac{3}{4}$; poultry $\frac{1}{3}$; marketing hogs 2 men and 2 teams 5 ; hauling manure to corn land 2 men and 1 team $2 \frac{1}{2} \ldots$ Eggs laid $22 \ldots$. . Set aside for home use: 1 gallon milk, 1 pint cream, 4 eggs.

Weight of feeds fed to live stock to-day: Cattle-Corn fodder $130 \mathrm{lbs}$., hay $36 \mathrm{lbs}$, ground feed $79 \mathrm{lbs}$., skim milk 65 lbs.; horses-Hay 165 lbs., oats 69 lbs.; hogs-Corn on

Think twice before you speak and then talk to yourself.-Hubbard. 
cob 105 lbs. and all skim milk and buttermilk not otherwise used; poultry-Oats 12 lbs., corn on cob 4 lbs.

The weight of milk given by each cow, morning and evening, was as follows: Red Heifer, morning 5.9 lbs., evening 6 lbs.; Nell, morning 9 lbs., evening 8.7 lbs.; Black and White Heifer, morning 3.3 lbs., evening 3 lbs. ; Crossy, mol'ning 10.1 lbs., evening $10 \mathrm{lbs} . ;$ Whitey, morning 5.9 lbs., evening 6.1 lbs.; Black and White Cow, morning 7.7 lbs., evening 7.4 lbs.; Durham, morning 8.6 lbs., evening 8.2 lbs.; Dot, morning 12.8 lbs., evening 12.5 lbs.; Star, morning 3.5 lbs., evening 3.2 lbs.; Holstein, morning 17.2 lbs., evening 17.3 lbs.

Took sample of each cow's milk at both milkings to-day for composite test.

Mar. 16.-Paid barber 35c.... Bought of Mercantile Co. on account, crackers 53c; blanket $\$ 1 . .$. Sold Mercantile Co. on account, $13 \frac{3}{4} \mathrm{lbs}$. butter at $22 \mathrm{c}$... Received check from Crescent Creamery Co. for milk delivered to them January 25 th $\$ 8.44^{*} \ldots$ Sold $1 \mathrm{qt}$. cream $20 \mathrm{c} \ldots$...Hours of labor: Cattle $4 \frac{1}{2}$; horses 2 ; hogs $\frac{3}{4}$; poultry $\frac{1}{3}$; hauling manure to corn land 1 man $1 \frac{1}{4}$; sacking grist for feed 1 man $1 \frac{1}{4}$; cutting wood 1 man $1 \frac{3}{4} \ldots$ Eggs laid $25 \ldots$. Set aside for home use: $1 \frac{1}{2}$ gallons milk, 1 pint cream, 6 eggs.

Mar. 17.-Hours of labor: Cattle $4 \frac{1}{2}$; horses 2 ; hogs $\frac{3}{4}$; poultry $\frac{1}{3}$; hauling manure to corn land 2 men and team 4 ; churning 1 man $1 \frac{1}{2} \ldots$ Eggs laid $24 \ldots$. Set aside for home use: $1 \frac{1}{4}$ gallons milk, 1 quart cream, 7 eggs.

Mar. 18.-Paid telephone rent to Oct., 1904, \$6.30; grinding feed 60c; 1 sack bran $47 \mathrm{c} \dagger$; camphor $15 \mathrm{c}$; insoles $10 \mathrm{c}$; flower fund of Degree of Honor 25c; A. O. U. W. assessment $\$ 1 \ldots$ Bought of Mercantile Co. on account, rice 25c; lemon extract $10 \mathrm{c} . .$. Hours of labor: Cattle $4 \frac{1}{2}$; horses 2 ; hogs $\frac{3}{4}$;

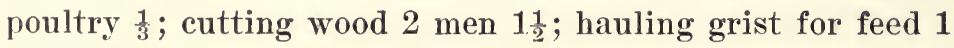
man and team $4 \ldots$ Eggs laid $30 \ldots$ Set aside for home use: $1 \frac{1}{4}$ gallons milk, 8 eggs.

*Debit cash $\$ 8.44$; credit Crescent Creamery Co. $\$ 8.40$ and Cattle $4 \mathrm{c}$. †Chg. Cattle.

"You must work to be happy." 
Mar. 19.-Paid for coal $\$ 21.75$; medicine $95 \mathrm{c} . .$. Sold $\frac{1}{2}$ gallon cream 40c....Hours of labor: Cattle $4 \frac{1}{2}$; horses 2; hogs $\frac{3}{4}$; poultry $\frac{1}{3}$; churning 1 woman $1 \frac{1}{2}$; hauling manure to corn land 1 man and team 4... Eggs laid 24... Set aside for home use: $1 \frac{3}{8}$ gallons milk, 1 pint cream, 12 eggs.

Mar. 20.-Hours of labor: Cattle $4 \frac{1}{2}$; horses 2 ; hogs $\frac{3}{4}$; poultry $\frac{1}{3} \ldots$... Eggs laid $28 \ldots$. Set aside for home use: $1 \frac{3}{8}$ gallons milk, 1 pint cream, 8 eggs, 5 pounds butter.

Mar. 21.-Paid for medicine $10 \mathrm{c}$; bananas $15 \mathrm{c} . .$. Bought of Mercantile Co. on account, sugar $\$ 1$; prunes $50 \mathrm{c}$; yeast 10c; darning cotton 10c.... Sold to Mercantile Co. on account, $9 \frac{1}{4}$ lbs. butter at $22 \mathrm{c} .$. . Sold $\frac{1}{2}$ gallon cream $40 \mathrm{c} \ldots$. Hours of labor: Cattle $4 \frac{1}{2}$; horses 2 ; hogs $\frac{3}{4}$; poultry $\frac{1}{3}$; cutting wood 2 men $1 \frac{1}{2} \ldots$. Eggs laid $31 \ldots$... Set aside for home use: $1 \frac{1}{2}$ gallons milk, 18 eggs.

Mar. 22.-Hours of labor: Cattle $4 \frac{1}{2}$; horses 2; hogs $\frac{3}{4}$; poultry $\frac{1}{3}$; cutting wood 2 men $4 \frac{1}{2} \ldots$ Eggs laid $33 \ldots$.... Set aside for home use: $1 \frac{3}{8}$ gallons milk, 1 pint cream, 1 egg.

Mar. 23.-Paid for fish 1Sc; postage 20c; medicine 20c; bananas $15 \mathrm{c}$; shoes and blacking $\$ 3.10$; towel $15 \mathrm{c} . .$. Bought of Mercantile Co. on account, starch 10c; soap 50c; birdseed $10 \mathrm{c}$; lamp chimney $10 \mathrm{c}$; salt $15 \mathrm{c}$; gingham $37 \mathrm{c}$; calico 70c; oranges $15 \mathrm{c} . .$. Sold Mercantile Co. on account, 14 lbs. butter at $22 \mathrm{c} . .$. Sold $\frac{1}{2}$ gallon cream $40 \mathrm{c} ; 5$ lbs. butter at 22c....Hours of labor: Cattle $4 \frac{1}{2}$; horses 2 ; hogs $\frac{3}{4}$; poul. try $\frac{1}{3}$; cutting wood 2 men $3 \frac{1}{2} \ldots$ Eggs laid $28 \ldots$... Set aside for home use: $1 \frac{3}{4}$ gallons milk, 3 pints cream, 7 eggs.

Mar. 24.-Hours of labor: Cattle $4 \frac{1}{2}$; horses 2; hogs $\frac{3}{4}$; poultry $\frac{1}{3}$; churning 1 woman 2 ; cutting wood 2 men $1 \frac{1}{2} \ldots$ Eggs laid 32.... Set aside for home use: 15 gallons milk, 1 pint cream, 12 eggs, $4 \frac{1}{2}$ pounds dressed chicken.

Mar. 25.-Hours of labor: Cattle $4 \frac{1}{2}$; horses 2 ; hogs $\frac{3}{4}$; poultry $\frac{1}{3}$; covering wood 2 men 2 ; cutting wood 2 men $3 . .$. Eggs laid $38 \ldots$... Set aside for home use: $1 \frac{1}{2}$ gallons milk, 1 pint cream, 10 eggs.

The man who does his work well will hold his job.--Hubbard. 
Weight of feeds fed to live stock to-day: Cattle-Corn fodder 132 lbs., hay 33 lbs., ground feed 78 lbs., skim milk 65 lbs.; horses-Hay 170 lbs., oats 75 lbs.; hogs-Corn on cob 75 lbs. and all skim milk and buttermilk not otherwise used; poultry-Oats 10 lbs., corn on cob 4 lbs.

Each cow's milk was weighed to-day, morning and evening, with the following results: Red Heifer, morning 5.8 lbs., erening 5.7 lbs.; Nell, morning 8.5 lbs., evening 8.3 lbs.; Black and White Heifer, morning 3 lbs., evening 2.9 lbs.; Crossy, morning 9.7 lbs., evening 9.7 lbs.; Whitey, morning 5.7 lbs., evening 5.8 lbs.; Black and White Cow, morning 7.5 lbs., evening 7.3 lbs.; Durham, morning 8.4 lbs., evening 8 Ibs.; Dot, morning 12.3 lbs., evening 12.2 lbs.; Star, morning 2.9 lbs., evening 3 lbs.; Holstein, morning 17.1 lbs., evening $17.2 \mathrm{lbs}$.

Took sample of each cow's milk at both milkings to-day for composite test.

Mar. 26.-Paid for clothing $75 \mathrm{c} . .$. Sold 1 qt. cream 20c; 5 lbs. butter at $22 \mathrm{c} \ldots$... Hours of labor: Cattle $4 \frac{1}{2}$; horses 2 ; hogs $\frac{3}{4}$; poultry $\frac{1}{3}$; cutting wood 2 men 3 ; marketing milk, cream and butter 1 man and team 3... Eggs laid 26... Set aside for home use: $1 \frac{3}{4}$ gallons milk, 1 pint cream, 8 eggs.

A test was made to-day of the composite samples of each cow's milk taken on the 5th, 15th and 25th of the month. This test shows the per cent of butter fat in each cow's milk as follows: Red Heifer 3.9; Nell 3.4; Black and White Heifer 4.1; Crossy 3.5; Whitey 3.8; Black and White Cow 4; Durham 3.7; Dot 3.9; Star 4.2; Holstein 2.8.

Tested sample of this morning's cream, which showed 27 per cent butter fat.

Mar. 27.-Hours of labor: Cattle $4 \frac{1}{2}$; horses 2 ; hogs $\frac{3}{4}$; poultry $\frac{1}{3}$; churning 1 woman $2 \ldots$ Eggs laid $37 \ldots$... Set aside for home use: $1 \frac{3}{8}$ gallons milk, 1 pint cream, 2 eggs. Mar. 28.--Paid for medicine $\$ 1$; apples $50 \mathrm{c} . .$. Bought of Mercantile Co. on account, prunes and crackers $\$ 1.75 \ldots$

The man who tells you all of his troubles becomes one of yours. -Hubbard. 
Hours of labor: Cattle $4 \frac{1}{2}$; horses 2 ; hogs $\frac{3}{4}$; poultry $\frac{1}{3}$; marketing oats and hauling home coal at one trip to town, 1 man and team 3 (Time should be divided equally between Oats and Food and Fuel).... Eggs laid 40.... Set aside for home use: $1 \frac{1}{4}$ gallons milk, 1 pint cream, 7 eggs.

Mar. 29.-Hours of labor: Cattle $4 \frac{1}{2}$; horses 2 ; hogs $\frac{3}{4}$; poultry $\frac{1}{3}$; hauling manure to corn land 1 man and team 5 ; 2 men and team 4; churning 1 woman 2 ; breaking cornstalks on field for barley 1 man and team 2... Eggs laid 31 ... Set aside for home use: $1 \frac{1}{4}$ gallons milk, 14 eggs.

Mar. 30.-Paid for teapot and pan $\$ 1$; pills 25c; grinding feed $60 \mathrm{c} . .$. Bought of Mercantile Co. on account, sugar $15 \mathrm{c}$; oranges $50 \mathrm{c} . .$. Sold Mercantile Co. on account, 5 lbs. butter at $23 \mathrm{c} .$. . Sold 1 qt. cream $20 \mathrm{c}$....Hours of labor: Cattle $4 \frac{1}{2}$; lorses 2 ; hogs $\frac{3}{4}$; poultry $\frac{1}{3}$; cutting wood 1 man $1 \frac{1}{4}$; hauling grist for feed 1 man and team 5, 1 man 1...Eggs laid 39 ... Set aside for home use: $1 \frac{1}{2}$ gallons milk, 3 pints cream, 12 eggs.

Mar. 31.-Paid for gingham 25c.... Sold Mercantile Co. on account, $9 \frac{1}{2} \mathrm{lbs}$. butter at $23 \mathrm{c}$.... Received from F. B. Headley for board $\$ 5.60$; room $\$ 1 ; 115 \mathrm{lbs}$. oats at $36 \mathrm{c}$ per bu.; hay $\$ 1.50$; barn room for horse $\$ 2.50 *$... Hours of labor: Cattle $4 \frac{1}{2}$; horses 2 ; hogs $\frac{3}{4}$; poultry $\frac{1}{3}$; churning 1 woman 2; putting sawdust on ice 1 man $1 \frac{1}{4}$ (Charge Farm Expense).... Eggs laid $37 \ldots$. Set aside for home use: $1 \frac{1}{2}$ gallons milk, 3 pints cream, 7 eggs, 5 lbs. butter,

Wherever man labor for a month amounts to more than 300 hours it will be assumed that the monthly wage is for 300 hours and that the excess will be figured at the same rate.

The rate of wages during the month is $\$ 18$ and board. The board is figured at $\$ 2.50$ per week.

The prices of feeds and products used during the month

${ }^{*}$ Credit Farm Expense with barn room earnings.

A good anvil does not fear the hammer.-Italian. 
are as follows: Corn fodder $\$ 3$ per ton; hay $\$ 7$ per ton; oats $35 \mathrm{c}$ per bushel; corn 36c per bushel; barley 36c per bushel; whole milk $\$ 1$ per hundred; skim milk $15 \mathrm{c}$ per hundred; cream 80c per gallon; butter 23c per pound; eggs 14c per dozen; dressed chicken $9 \mathrm{c}$ per pound.

\section{INVENTORY.}

Inventory of real estate and personal property, March 31, 1904 :

This inventory was made that the business might be closed at this time. It is not exact since it was not made on the farm on the above date, but serves as a lesson in closing the accounts. Real Estate, $\$ 9,600.00$; horses, $\$ 480.00$; cattle, $\$ 491.00$; hogs, $\$ 163.60$; poultry, $\$ 29.75$; machinery and implements, $\$ 443.70$; oats, 1050 bushels at $36 \mathrm{c}, \$ 378.00$; barley, 158 bushels at $35 \mathrm{c}, \$ 55.30$; corn and fodder, $\$ 120.00$; Hay, $\$ 260.00$; clothing, $\$ 145.00$; food and fuel, $\$ 60.00$; farm expense, \$32.61; Household Furnishings, \$488. Total, \$12,746.96 .

Beware of the man who counsels your advancement at the expense of your neighbor.-Hubbard. 


\section{CHAPTER X.}

\section{PRACTICE WORK.}

Apr. 1.-Hours of labor: Cattle $4 \frac{1}{2}$; horses 2 ; hogs $\frac{3}{4}$; poultry $\frac{1}{3}$; cutting and piling wood 1 man 5,1 man $4 \ldots$. Eggs laid $31 \ldots$. Set aside for home use: $1 \frac{3}{8}$ gallons milk, 1 pint cream, 8 eggs.

$\Delta$ pr. 2.-Paid for medicine $30 \mathrm{c}$; bananas $13 \mathrm{c}$; repair of harness 20c....Bought of Mercantile Co. on account, oranges and graham flour $60 \mathrm{c} \ldots$...Sold Mrs. Martin on account, 1 qt. cream 20c... Sold 24 doz. 5 eggs at $15 \mathrm{c} ; 2$ gallons cream at $80 \mathrm{c} . .$. Hours of labor: Cattle $4 \frac{1}{2}$; horses 2 ; $\operatorname{hogs} \frac{3}{4}$; poultry $\frac{1}{3}$; cutting wood 1 man 2 ; breaking cornstalks on field for barley 1 man and team $3 \frac{1}{2}$; churning 1 woman $2 \ldots$ Eggs laid $40 \ldots$. Set aside for home use: $1 \frac{1}{2}$ gallons milk, 3 pints cream, 22 eggs.

Apr. 3.-Hours of labor: Cattle $4 \frac{1}{2}$; horses 2 ; hogs $\frac{3}{4}$; poultry $\frac{1}{3} \ldots$... Eggs laid $35 . .$. Set aside for home use: $1 \frac{5}{8}$ gallons milk, 1 pint cream, 6 eggs, $4 \frac{1}{2}$ pounds butter.

Apr. 4.-Hours of labor: Cattle $4 \frac{1}{2}$; horses 2 ; hogs $\frac{3}{4}$; poultry $\frac{1}{3}$; marketing steers 2 men and team $3 \ldots$... Eggs laid 35 ... Set aside for home use: $1 \frac{3}{8}$ gallons milk, 1 pint cream, 6 eggs.

Apr. 5.-Paid for bananas 15c; beef 25c; dry goods 65c ....Bought of Mercantile Co. on account, sugar, cheese and apricots $\$ 1.85$; calico $15 \mathrm{c} \ldots .$. Sold to Mercantile Co. on account, $9 \underset{2}{2} \mathrm{lbs}$. butter at $23 \mathrm{c} . .$. Sold two steers $\$ 113.10$; $25 / 16$ gallons cream at 80c.... Hours of labor: Cattle $4 \frac{1}{2}$; horses 2 ; hogs $\frac{3}{4}$; poultry $\frac{1}{3}$; trip to Austin 2 men and team 5 (Charge Farm Expense); churning 1 woman 2... Eggs laid 12 ... Set aside for home use: $1 \frac{5}{8}$ gallons milk, 1 pint cream, 2 eggs.

The fortress that parleys soon surrenders.-Italian. 
Weight of feeds fed to live stock to-day: Cattle-Corn fodder 105 lbs., hay 195 lbs., ground feed 60 lbs., skim milk 90 lbs.; horses-Hay 135 lbs., oats 70 lbs., colts are on pasture. hogs-Corn on cob 102 lbs. and all skim milk and buttermilk not otherwise used; poultry-Oats 8 lbs, corn on cob 5 lbs.

Following is the weight of milk given by each cow, morning and evening: Red Heifer, morning 5.7 lbs., evening 5.4 Ibs.; Nell, morning 8.5 lbs., evening 8 lbs.; Crossy, morning 9.5 lbs., evening 9.2 lbs.; Black and White Cow, morning 7.5 lbs., evening 7.3 lbs.; Durham, morning 7.8 lbs., evening 7.5 lbs.; Dot, morning 12 lbs., evening 11.8 lbs.; Holstein, morning 16.3 lbs., evening $15.8 \mathrm{lbs}$.

A sample of each cow's milk was taken at each milking to-day for composite test.

Apr. 6.-Hours of labor: Cattle $4 \frac{1}{2}$; horses 2 ; hogs $\frac{3}{4}$; poultry $\frac{1}{3}$; * repairing fence 1 man $1 \frac{1}{2}$; †burning grass along road and in yard 1 man $2 \frac{1}{2}$; putting sawdust on ice 1 man $\frac{1}{2}$; hauling manure to corn land 1 man and team 3 ; churning 1 women 2....Eggs laid 33.... Set aside for home use: 1 7/16 gallons milk, 1 pint cream, 9 eggs, 5 pounds butter. Apr. 7.- Paid for medicine $\$ 2.25$; coffee $60 \mathrm{c}$; bananas and berries 50c; 15 lbs. timothy at $\$ 3.50$ per hundred; 25 lbs. clover at $\$ 8$ per hundred; horse collar $\$ 1.50$; horse shoeing $80 \mathrm{c} . .$. Bought of Mercantile Co. on account, bananas $17 \mathrm{c}$ ....Sold Mercantile Co. on account, 5 lbs. butter at 23c; 10 dozen eggs at $13 \mathrm{c} \ldots$. Sold $1 \frac{1}{2}$ dozen eggs at $13 \mathrm{c} . .$. Hours of labor: Cattle $4 \frac{1}{2}$; horses 2 ; hogs $\frac{3}{4}$; poultry $\frac{1}{3}$; hauling manure to corn land 1 man and team $3 \frac{3}{4}, 1$ man $1 \frac{1}{2}$; repairing fence 1 man and team $\frac{3}{4}$; marketing milk, butter and cream 1 man and horse $3 \ldots$ Eggs laid $34 \ldots$... Set aside for home use: 17 gallons milk, 1 pint cream.

Apr. 8.-Hours of labor: Cattle $4 \frac{1}{2} ;$ horses 2 ; $\operatorname{logs} \frac{3}{4}$; poultry $\frac{1}{3}$; churning 1 woman 2 ; cleaning seed oats 2 men 2 ....Eggs laid $43 \ldots$... Set aside for home use: $1 \frac{3}{8}$ gallons milk, 1 pint cream, 7 eggs.

\footnotetext{
*†Charge Farm Expense.
}

Life gives nothing to men without great labor.-Horace. 
Apr. 9.-Paid for 2 pairs rubbers $\$ 1.15$; sharpening plow 35c; barber 10c; Dr. Brubaker's bill rendered to-day $\$ 15$ ....Bought of Mercantile Co. on account, tapioca $70 \mathrm{c}$; dress trimmings $96 \mathrm{c}$; baking powder $65 \mathrm{c}$; thread $10 \mathrm{c} . .$. Sold 177 lbs. oats at $34 \mathrm{c} ; 3$ quarts cream 60c.... Received from F. B. Headley for board $\$ 6.60$; care of horse $\$ 1 .$. Sold Mercantile Co. on account, $4 \frac{1}{2} \mathrm{lbs}$. butter at $23 \mathrm{c} . .$. Hours of labor: Cattle $4 \frac{1}{2}$; horses 2 ; hogs $\frac{3}{4}$; poultry $\frac{1}{3} \ldots$ Eggs laid 35.... Set aside for home use: $1 \frac{5}{8}$ gallons milk, 3 pints cream, 18 eggs.

Apr. 10.-Hours of labor: Cattle $4 \frac{1}{2}$; horses 2 ; hogs $\frac{3}{4}$; poultry $\frac{1}{3} \ldots$ Eggs laid $36 \ldots$... Set aside for home use: $1 \frac{3}{8}$ gallons milk, 1 pint cream, 7 eggs, 5 pounds butter.

Apr. 11.-Hours of labor: Cattle $4 \frac{1}{2}$; horses 2 ; hogs $\frac{3}{4}$; poul. try $\frac{1}{3}$; cleaning seed oats 2 men 2 ; cleaning succotash 2 men 2 (This mixture was given in the inventory as Oats. The labor cost and wheat cleaned out should be respectively charged and credited to Oats); churning 1 woman 2.... Eggs laid 33... Set aside for home use: $1 \frac{1}{2}$ gallons milk, 1 pint cream, 2 eggs.

Apr. 12.-- Paid fire insurance premium on $\$ 500$ for three years from date at $\$ 1.10$; medicine $50 \mathrm{c}$; bananas $15 \mathrm{c}$; rubber ball 10c.... Sold 1 qt. cream $20 \mathrm{c} . .$. Sold Mercantile Co. on account, 5 lbs. butter at $23 \mathrm{c} ; 12$ dozen eggs at $13 \mathrm{c} . .$. Hours of labor: Cattle $4 \frac{1}{2}$; horses 2 ; hogs $\frac{3}{4}$; poultry $\frac{1}{3}$; cleaning chicken house 1 man $\frac{3}{4}$; putting sawdust on ice 1 man $\frac{1}{2}$; cleaning succotash 3 men $1 \frac{1}{2}$; marketing butter and cream 1 man and team $3 \ldots$ Eggs laid $35 \ldots$... Set aside for home use: $1 \frac{3}{4}$ gallons milk, 1 quart cream, 8 eggs.

Apr. 13.-Paid for medicine 20c.... Hours of labor: Cattle $4 \frac{1}{2}$; horses 2 ; hogs $\frac{3}{4}$; poultry $\frac{1}{3}$; hauling grist for feed and bringing back coal 1 man and team 4, 2 men $\frac{1}{2}$ (Divide this charge equally between Ground Feed and Food and Fuel);

*Charge Farm Expense.

Success consists in the ability to say yes or no at the proper time. 
taking off storm †windows 1 man 2 ; taking away banking from house 1 man $1 \frac{1}{2}$; churning 1 woman $2 \ldots$ Eggs laid 37 .... Set aside for home use: $1 \frac{3}{4}$ gallons milk, 1 pint cream, 20 eggs.

Apr. 14.-Paid for grinding feed $60 \mathrm{c}$; bran $\$ 1.60$; potatoes $\$ 1.35$; Dr. Brubaker $\$ 28$; Dr. Philips $\$ 8 . .$. Bought of Mercantile Co. on account, seed potatoes $\$ 1.40$; breakfast food $30 \mathrm{c}$....Hours of labor: Cattle $4 \frac{1}{2}$; horses 2 ; hogs $\frac{3}{4}$; poultry $\frac{1}{3}$; marketing oats and hauling home ground feed 1 man and team 4 ; hauling wood 1 man and team $4 \frac{3}{4}$; fencing 1 man and team 1; putting sawdust on ice 1 man $\frac{1}{2}$; cutting wood 2 men $\frac{1}{2} \ldots$... Eggs laid 28 .... Set aside for home use: $1 \frac{1}{2}$ gallons milk, 1 pint cream, 15 eggs, 5 pounds butter.

Apr. 15.-Paid for entertainment 50c.... Sold 5 lbs. butter $\$ 1.15 ; 1$ qt. cream $20 \mathrm{c} . .$. Sold Mrs. Sherpy on account, $4 \frac{1}{2} \mathrm{lbs}$. butter at $23 \mathrm{c} . .$. Hours of labor: Cattle $4 \frac{1}{2}$; horses 2 ; hogs $\frac{3}{4}$; poultry $\frac{1}{3}$; churning 1 woman $2 \ldots$ Eggs laid 33 .... Set aside for home use: $1 \frac{1}{2}$ gallons milk, 3 pints cream, 4 eggs.

Weight of feeds fed to live stock to-day: Cattle-Corn fodder $85 \mathrm{lbs}$., hay $210 \mathrm{lbs}$., ground feed $45 \mathrm{lbs}$., skim milk 90 lbs.; horses-Hay 121 lbs., oats 63 lbs.; hogs-Corn on cob $102 \mathrm{lbs}$. and all skim milk and buttermilk not otherwise used; poultry-Oats 5 lbs., corn on cob 5 lbs.

Following is the weight of milk given by each cow, morning and evening: Red Heifer, morning 5.2 lbs., evening 5 lbs.; Nell, morning 7.9 lbs., evening 8.2 lbs.; Crossy, morning 9.3 hbs., evening, 9.2 lbs.; Black and White Cow, morning $7 \mathrm{lbs}$, evening $6.9 \mathrm{lbs}$; Durham, morning 7 lbs., evening 7.2 lbs.; Dot, morning 11.4 lbs., evening 11.6 lbs.; Holstein, morning $15.2 \mathrm{lbs}$, evening $14.9 \mathrm{lbs}$.

Samples were taken of each cow's milk morning and even. ing today for composite test.

† Charge Farm Expense with taking off windows and with taking away banking.

A ragged colt may make a handsome horse.-Spanish. 
Apr. 16.-Hours of labor: Cattle $4 \frac{1}{2}$; horses 2 ; hogs $\frac{3}{4}$; poultry $\frac{1}{3}$; hauling 12 loads of manure, 9 to corn field and three to ${ }^{*}$ garden, 2 men and team 6 ; churning 1 woman 2 ....Eggs laid $24 \ldots$... Set aside for home use: $1 \frac{1}{2}$ gallons milk, 1 pint cream, 13 eggs.

Apr. 17.-Hours of labor: Cattle $4 \frac{1}{2}$; horses 2; hogs $\frac{3}{4}$; poultry $\frac{1}{3} \ldots$ Eggs laid $34 \ldots$... Set aside for home use: $1 \frac{3}{8}$ gallons milk, 5 eggs.

Apr. 18.-Paid for tub and broom $\$ 1.10$; meat $25 \mathrm{c}$; sharpening razor 20c; harness repairs $15 \mathrm{c} . .$. Bought of Mercantile Co. on account, kerosene $16 \mathrm{c}$; vinegar $20 \mathrm{c}$; sugar $\$ 1$; peaches 50c; prunes 50c; lamp chimney $10 \mathrm{c}$; broom $25 \mathrm{c}$; yeast $10 \mathrm{c}$; wicks $5 \mathrm{c}$; raisins $30 \mathrm{c}$; oranges $50 \mathrm{c} . .$. Sold Mercantile Co. on account, $9 \frac{1}{2} \mathrm{lbs}$. butter at $23 \mathrm{c} ; 2$ doz. eggs at $14 \mathrm{c} . .$. Sold $2,406 \mathrm{lbs}$. hogs at $\$ 4.25$. Received for boarding horse $\$ 20 \ldots$ Hours of labor: Cattle $4 \frac{1}{2}$; horses 2 : hogs $\frac{3}{4}$; poultry $\frac{1}{3}$; hauling rock from pasture 1 man and team 3 (Charge Real Estate); raking stalks on barley field 1 man and team 3.... Eggs laid $23 \ldots$ Set aside for home use: $2 \frac{1}{s}$ gallons milk, 3 pints cream, 35 eggs.... Set under hen 12 eggs.

Apr. 19.-Hours of labor: Cattle $4 \frac{1}{2}$; horses 2 ; hogs $\frac{3}{4}$; poultry $\frac{1}{3}$; churning 1 woman 2 ; burning stalks on barley field 1 man $3 \frac{1}{2}$; marketing hogs sold yesterday 1 man and team 5, 1 man $\frac{1}{2}$; plowing on barley field 1 man and 3 horses $2 \frac{3}{4}$; raking stalks on barley field 1 man and team $3 \ldots$ Eggs laid $31 \ldots$. Set aside for home use: $1 \frac{3}{8}$ gallons milk, 1 quart cream, 17 eggs, 5 pounds butter.

Apr. 20.-Paid for oatmeal 20c; bananas 20c; gloves 25c; vaseline $15 \mathrm{c}$; medicine $20 \mathrm{c}$; spices $12 \mathrm{c}$; laundry $20 \mathrm{c}$; dress goods $\$ 5.50 \ldots$. . Bought of Mercantile Co. on account, 1 pair gloves $50 \mathrm{c} . .$. Sold Mercantile Co. on account, $5 \mathrm{lbs}$. butter at $23 \mathrm{c} ; 8$ dozen eggs at $14 \mathrm{c} . .$. Hours of labor: Cattle $4 \frac{1}{2}$; horses 2 ; hogs $\frac{3}{4}$; poultry $\frac{1}{3}$; plowing barley field 1 man and 3 horses $8 \frac{1}{2}$; dragging on oat field 1 man and team $4 \frac{1}{2}$; marketing butter and milk 1 man and horse $3 \ldots$... Eggs laid

* Charge Garden

"A man must ask his wife's leave to thrive." 
$34 \ldots$ Set aside for home use: $2 \frac{1}{8}$ gallons milk, 3 pints cream, 3 eggs. Set under hens 24 eggs.

Apr. 21.-Hours of labor: Cattle $4 \frac{1}{2}$; horses 2 ; hogs $\frac{3}{4}$; poultry $\frac{1}{3}$; plowing on barley field 1 man and 3 horses $7 \frac{1}{2}$; dragging oat field 1 man and team 5; churning 1 woman $\frac{1}{2}$ ..... Eggs laid $26 \ldots$... Set aside for home use: $1 \frac{3}{8}$ gallons milk, 1 pint cream, 1 egg.

Apr. 22.-Bought of Mercantile Co. on account, oranges and cheese $75 \mathrm{c} . .$. Sold Mercantile Co. on account, 5 lbs. butter at $23 c . .$. Hours of labor: Cattle $4 \frac{1}{2}$; horses 2 ; hogs $\frac{3}{4}$; poultry $\frac{1}{3}$; plowing on barley field 1 man and 3 horses 4 ; marketing butter and milk 1 man and horse $3 . .$. Eggs laid $35 . .$. Set aside for home use : $1 \frac{3}{4}$ gallons milk, 3 pints cream, 2 eggs.

Apr. 23.-Hours of labor: Cattle $4 \frac{1}{2}$; horses 2 ; hogs $\frac{3}{4}$; poultry $\frac{1}{3}$; plowing on barley field 1 man and 3 horses 8 ; dragging on oat field 1 man and team $5 \frac{1}{2}$; plowing corn field 1 man and team $1 \frac{1}{2}$; sacking oats for market 1 man 1 ; covering ice with sawdust 1 man $\frac{1}{2}$; repairing seeder 1 man 1 ; churning 1 woman $2 \ldots$ Eggs laid $28 \ldots$... Set aside for home use : $1 \frac{3}{\delta}$ gallons milk, 1 quart cream, 18 eggs.

Apr. 24.-Gave Ed. Hibbard (son) \$5....Received for boarding horse $\$ 13.50 \ldots$ Hours of labor: Cattle $4 \frac{1}{2}$; horses 2 ; hogs $\frac{3}{4}$; poultry $\frac{1}{3} \ldots$... Eggs laid 27 . . . Set aside for home use: $1 \frac{5}{8}$ gallons milk, 1 pint cream, 2 eggs, $4 \frac{1}{2}$ pounds dressed chicken.

Apr, 25.-Bonght of Mercantile Co. on account, baking soda 55c; muslin and embroidery 59c.... Sold $10 \mathrm{lbs}$. butter at 23c....Hours of labor: Cattle $4 \frac{1}{2}$; horses 2 ; hogs $\frac{3}{4}$; poultry $\frac{1}{3}$; sowing oats 1 man and team $7 \frac{3}{4}$; dragging on oat field 1 man and team $6 \frac{1}{2} \ldots$ Eggs laid $29 \ldots$. Set aside for home use: $1 \frac{5}{8}$ gallons milk, 1 pint cream, 6 eggs, 5 pounds butter.

Weight of feeds fed to live stock to-day: Cattle-Corn fodder 65 lbs., hay 225 lbs., ground feed 36 lbs., skim milk

Enjoy the present day, embrace the opportunity, improve time.Latin. 
90 lbs.; horses-Hay 104 lbs., oats 68 lbs.; hogs-Corn on cob 99 lbs. and all skim milk and buttermilk not otherwise used; poultry-Oats 5 lbs., corn on cob 5 lbs.

Following is the weight of milk given by each cow, morning and evening: Red Heifer, morning 4 lbs., evening 3.5 lbs.; Nell, morning 8.3 lbs., evening 8 lbs.; Crossy, morning 9.3 lbs., evening 9 lbs.; Black and White Cow, morning 6.6 lbs., evening 6.4 lbs.; Durham, morning 6.9 lbs., evening 6.5 lbs.; Dot, morning 11.8 lbs., evening 11.6 lbs.; Holstein, morning 14.5 lbs., evening 14.2 lbs.

A sample of each cow's milk was taken at both milkings to-day for composite test.

Apr. 26.-Hours of labor: Cattle $4 \frac{1}{2}$; horses 2 ; hogs $\frac{3}{4}$; poultry $\frac{1}{3}$; plowing on barley field 1 man and 3 horses 2; sowing oats 1 man and team 3; dragging oat field 1 man and team $6 \frac{1}{2}$; sacking seed oats 2 men $\frac{1}{2} \ldots$ Eggs laid 26 .... Set aside for home use: $1 \frac{3}{8}$ gallons milk, 1 pint cream, 8 eggs.

Apr. 27.-Paid for curtains $\$ 12.30$; dress goods $\$ 3.70 \ldots$ Bought of Mercantile Co. on account, sugar, tea, lemons, cream of tartar $\$ 1.88$; dress goods and trimmings $\$ 2.23$; garden seeds $15 \mathrm{c} . .$. Sold Mercantile Co. on account, $10 \mathrm{lbs}$. butter at 23c....Hours of labor: Cattle $4 \frac{1}{2}$; horses 2; hogs $\frac{3}{4}$; poultry $\frac{1}{3}$; plowing on barley field 1 man and team $2 \frac{1}{2}$; dragging on oat field 1 man and team $4 \frac{1}{2}$; hauling rock from pasture 1 man and team $\frac{1}{2}$; sowing oats 1 man and team $3 \frac{1}{2}$; sacking seed oats 2 men $\frac{1}{2}$.... Eggs laid $32 \ldots$. . Set aside for home use: $1 \frac{3}{4}$ gallons milk, 1 quart cream, 8 eggs.

A test was made to-day of the composite milk samples from each cow taken on the 5th, 15th and 25th of the month. The results expressed in per cent of butter fat were as follows: $\quad$ Red Heifer 4.1; Nell 3.2; Crossy 3.75; Black and White Cow 3.8; Durham 3.8; Dot 3.9; Holstein 3.1.

A sample of this morning's cream tested 28 per cent.

Apr. 28.-Hours of labor: Cattle $4 \frac{1}{2}$; horses 2: hogs $\frac{3}{4}$; poultry $\frac{1}{3}$; sowing oats 1 man and team 6 $\frac{1}{2}$; dragging on

Wishes were ever fools.-Shakespeare. 
oat field 1 man and team $6 \frac{1}{2}$; hauling rock from pasture 2 men and team $\frac{1}{2}$; cleaning seed oats 2 men $\frac{1}{2} \ldots$ Eggs laid 32 ... Set aside for home use: $1 \frac{1}{2}$ gallons milk, 1 pint cream.

Apr. 29.--Paid for medicine $\$ 1$; meat $50 \mathrm{c}$; oranges $30 \mathrm{c} . .$. Sold Mercantile Co. on account, 5 lbs. butter at 23c; 9 doz. eggs at $14 \mathrm{c} \ldots$...Sold 1 qt. cream 20c...Hours of labor: Cattle $4 \frac{1}{2}$; horses 2 ; $\operatorname{logs} \frac{3}{4}$; poultry $\frac{1}{3}$; sowing oats 1 man and team 8 ; dragging on oat field 1 man and team 6 ; pumping water for cattle 1 man $\frac{3}{4} \ldots$. Eggs laid $29 \ldots$. Set aside for home use: $1 \frac{1}{2}$ gallons milk, 1 quart cream, $4 \frac{1}{2}$ pounds butter.

Apr. 30.-Hours of labor: Cattle $4 \frac{1}{2}$; horses 2 ; hogs $\frac{3}{4}$; poultry $\frac{1}{3}$; plowing on barley field 1 man and team 2 ; dragging oat field 1 man and team 1; 2 men and 2 teams 4; sowing oats 1 man and team 4 ; sowing grass seed 1 man $\frac{1}{2}$; cleaning oats for seed 2 men $\frac{1}{4}$; burning grass along fences 1 man $1 \frac{1}{2}$; churning time for week 1 woman $5 .$. . Eggs laid $30 \ldots$ Set aside for home use: $1 \frac{1}{2}$ gallons milk, 1 quart cream.

The rate of wages during the month is $\$ 25$ per month and board. The board is figured at $\$ 2.50$ per week.

The prices of feeds and products used during the month are as follows: Corn fodder $\$ 3$ per ton; hay $\$ 7$ per ton; oats $35 \mathrm{c}$ per bushel; corn 40c per bushel; barley 36c per bushel; whole milk $\$ 1$ per hundred; skim milk $15 \mathrm{c}$ per hundred; cream 80c per gallon; butter 22c per pound; eggs 14c per dozen; dressed chicken $10 \mathrm{c}$ per pound.

May 1.-Paid for yroceries $25 \mathrm{c}$.... Hours of labor: Cat tle $4 \frac{1}{2}$; horses 2 ; hogs $\frac{3}{4}$; poultry $\frac{1}{3} \ldots$ Eggs laid $36 . .$. Set aside for hone use: $1 \frac{1}{2}$ gallons milk, 1 egg.

May 2.-Hours of labor: Cattle $4 \frac{1}{2}$; horses 2 ; hogs $\frac{3}{4}$; poultry $\frac{1}{3}$; dragging on oat field 2 men and 2 teams $3 \frac{1}{2}$; plowing barley field 1 man and 3 horses 3 ; uncovering strawberries 1 man $1 \frac{1}{2}$; covering ice with sawdust 1 man $\frac{1}{2}$; cleaning seed barley 2 men 1 ; sowing barley 1 man and team 8 ;

A fortress on its guard is not surprised.-Spanish. 
dragging barley field 1 man and team $6 \frac{1}{2} \ldots$ Eggs laid 40 .... Set aside for home use: $1 \frac{3}{8}$ gallons milk, 3 pints cream, 21 eggs.

May 3.-Hours of labor: Cattle $4 \frac{1}{2}$; horses 2: hogs $\frac{3}{4}$; poultry $\frac{1}{3}$; cleaning seed barley 2 men 1 ; sowing barley 1 man and team 8 ; dragging on barley field 1 man and team $6 \frac{1}{2} \ldots$ Eggs laid $41 \ldots$. Set aside for home use: $1 \frac{3}{8}$ gallons milk, 4 eggs.

May 4.-Bought of Mercantile Co. on account, oranges $30 \mathrm{c}$; pepper $10 \mathrm{c}$; syrup $50 \mathrm{c}$; cheese $30 \mathrm{c} . .$. Sold Mercantile Co. on account, 5 lbs. butter at $23 \mathrm{c} ; 10 \frac{1}{2}$ doz. eggs at $13 \mathrm{c} \ldots$ Hours of labor: Cattle $4 \frac{1}{2}$; horses 2 ; hogs $\frac{3}{4}$; poultry $\frac{1}{3}$; dragging barley field 1 man and team 5 ; hauling manure to corn land 1 man and team $2 \frac{1}{2}$; gardening 1 man 2 ; planting potatoes 1 man $1 \frac{1}{2} \ldots$ Eggs laid $27 \ldots$. Set aside for home use: $1 \frac{5}{8}$ gallons milk, 3 eggs.

May 5.-Hours of labor: Cattle $4 \frac{1}{2}$; horses 2; hogs $\frac{3}{4}$ : poultry $\frac{1}{3}$; hauling manure to corn land man and team $5 \frac{3}{4}$. 1 man $\frac{1}{2}$; gardening 1 man 3 ; cleaning yard 1 man $\frac{1}{2} \ldots$ Eggs laid 23.... Set aside for home use: $1 \frac{1}{2}$ gallons milk, 1 pint cream, 4 eggs.

Weight of feeds fed to live stock to-day: Cattle-Corn fodder $130 \mathrm{lbs}$. , hay $185 \mathrm{lbs}$., ground feed $30 \mathrm{lbs}$., oats $8 \mathrm{lbs}$. , skim milk 50 lbs.; horses-Hay 105 lbs., oats 50 lbs.; hogs - Corn on cob 16 lbs., barley 4 lbs., oats 3 lbs., and all skim milk and butter milk not otherwise used; poultry-Oats 5 lbs.

Each cow's milk was weighed to-day, morning and evening, with the following results: Nell, morning $7.5 \mathrm{lbs}$, even. ing 7.1 lbs.; Crossy, morning 9.1 lbs., evening S.S lbs.; Black and White Cow, morning 6.7 lbs., evening 6.6 lbs.; Durham, morning 6.2 lbs., evening 5.9 lbs.; Dot, morning 11.5 lbs., evening 11.3 lbs.; Holstein, morning 15.4 lbs., evening 15.6 lbs.

Samples of each cow's milk were taken at both milkings to-day for composite test.

"To say little and perform much, is the characteristic of great minds.', 
May 6.-Gave Ed (son) 85c; Florence (daughter) 50c.... Paid for paint for house $35 \mathrm{c}$; sulphur $10 \mathrm{c}$; watch chain $\$ 1.50$; hat $\$ 2$; dry goods $\$ 1.05 . .$. Bought of Mercantile Co. on account, garden seed $40 \mathrm{c}$; salmon and berries $90 \mathrm{c}$; jacket $75 \mathrm{c} . .$. Sold Mercantile Co. on account, $10 \mathrm{lbs}$. butter at 23c....Hours of labor: Cattle $4 \frac{1}{2}$; horses 2 ; hogs $\frac{3}{4}$; poultry $\frac{1}{3}$; hauling grist for feed 1 man and team 4 ; hauling manure to corn land 1 man 2 ; planting garden 1 man $1 \frac{1}{2} \ldots$ Eggs laid 39.... Set aside for home use: 15 gallons milk, 1 quart cream, 7 eggs, 5 pounds butter.

May 7.-Paid for grinding feed 50c; barber 50c; horse shoeing 40c; oil for cream separator $15 \mathrm{c}$; garden seeds $10 \mathrm{c}$; bananas $10 \mathrm{c}$; harness repairs $10 \mathrm{c} .$. . Sold $4 \frac{3}{4}$ bu. barley at $40 \mathrm{c}$....Hours of labor: Cattle $4 \frac{1}{2}$; horses 2 ; hogs $\frac{3}{4}$; poultry $\frac{1}{3}$; sacking feed 2 men $\frac{1}{2}$; putting away sleighs 2 men 1 ; hauling manure to oat field 1 man and team 7, 1 man 2; churning time for the week 1 woman 5... Eggs laid $32 \ldots$. Set aside for home use: $1 \frac{5}{8}$ gallons milk, 3 pints cream, 10 eggs.

May 8.-Hours of labor: Cattle $4 \frac{1}{2}$; horses 2; hogs $\frac{3}{4}$; poultry $\frac{1}{3} \ldots$ Eggs laid $36 . \ldots$... Set aside for home use: $1 \frac{3}{8}$ gallons milk.... Set under hen 12 eggs.

May 9.-Paid veterinarian for attending colt $\$ 1$... Sold Mercantile Co. on account, 5 lbs. butter at $23 \mathrm{c} . .$. Sold 1 quart cream 20c; 9 dozen eggs at 13 cents....Hours of labor:- Cattle $4 \frac{1}{2}$; horses 2 ; hogs $\frac{3}{4}$; poultry $\frac{1}{3}$; hauling manure to pasture land 1 man and team $4 ; 2$ men and team $3 ; 1$ man $3 \frac{1}{4}$; helping veterinarian with colt 2 men $\frac{1}{2}$; plowing on corn land 1 man and three horses $3 . .$. Eggs laid $30 \ldots$ Set aside for home use: $1 \frac{1}{2}$ gallons milk, 22 eggs.

May 10.-Paid for men's furnishings $90 \mathrm{c}$; bananas $15 \mathrm{c}$; meat 25c... Hlowrs of labor: Cattle $4 \frac{1}{2}$; horses 2 ; hogs $\frac{3}{4}$; poultry $\frac{1}{3}$; hauling manure to corn land 1 man and team 8 ; plowing on corn land 1 man and three horses 8 ; churning 1 woman $1 \frac{1}{4} \ldots$ Eggs laid $26 \ldots$. Set aside for home use: $1 \frac{3}{8}$ gallons milk, 1 pint cream.

No matter how hard adversity strikes, come up smiling. 
May 11.-Hours of labor: Cattle $4 \frac{1}{2}$; horses 2; hogs $\frac{3}{4}$; poultry $\frac{1}{3}$; plowing on corn land 1 man and 3 horses $8 \frac{1}{2}$; hauling manure to corn land 1 man and team $\frac{1}{2}$; dragging corn land 1 man and team $2 \frac{1}{2}$; planting potatoes 1 man $4 \frac{1}{2}, 1$ horse $1 \ldots$ Eggs laid $25 \ldots$. Set aside for home use: $1 \frac{5}{8}$ gallons milk, 1 pint cream, 1 egg, 5 pounds butter.

May 12.-Hours of labor: Cattle $4 \frac{1}{2}$; horses 2 ; hogs $\frac{3}{4}$ poultry $\frac{1}{3}$; plowing on corn land 1 man and 3 horses $3 \frac{1}{2}$ : hauling manure to corn land 2 men and team $1 \frac{1}{2}$; hauling manure to garden 2 men $\frac{1}{2}$; shelling seed corn 1 man 1 ; cutting seed potatoes 1 man 1 ; churning 1 woman $1 \frac{1}{2} \ldots$. Eggs laid $18 \ldots$... Set aside for home use: $1 \frac{3}{8}$ gallons milk, 7 eggs.

May 13.-Paid "real estate taxes $\$ 51.64$; coal $\$ 12.81$; A. O. U. W. life insurance assessment $\$ 2$; chair bottoms $22 \mathrm{c}$; thread 10c.... Bought of Mercantile Co. on account, oranges and yeast $35 \mathrm{c} . .$. Sold $7 \frac{1}{2} \mathrm{lbs}$. butter at $23 \mathrm{c} . .$. Hours of labor: Cattle $4 \frac{1}{2}$; horses 2 ; $\operatorname{hogs} \frac{3}{4}$; poultry $\frac{1}{3}$; plowing on corn land 1 man and 3 horses 5 ; marketing dairy produce 1 man and team 3 ; planting potatoes 1 man $2 \frac{1}{2}$; 1 horse 2 ....Eggs laid $33 \ldots$... Set aside for home use: 15 gallons milk, 1 pint cream, 2 eggs.

May 14.-Paid for harness $\$ 17$; lawn mower $\$ 3.50$; harness repairs $45 \mathrm{c} ; 1$ bu. seed corn $\$ 1.75$; meat $30 \mathrm{c}$; medicine $35 \mathrm{c} . .$. Bought of Mercantile Co. on account, cheese and ginger 50c.... Sold Mercantile Co. on account, 5 lbs. butter at $23 \mathrm{c} . .$. Sold 9 dozen eygs at $13 \mathrm{c} . .$. Hours of labor : Cattle $4 \frac{1}{2}$; horses 2 ; hogs $\frac{3}{4}$; poultry $\frac{1}{3}$; dragging corn land 1 man and team 7,1 man and team $2 \frac{1}{2}$; repairing fence 1 man $\frac{1}{2}$; killing gophers 1 man 1 ; gardening 1 man $\frac{1}{2} \ldots$ Eggs laid 18... Set aside for home use: $1 \frac{5}{8}$ gallons mill, 3 pints cream, 11 eggs.

May 15.-Hours of labor: Cattle $4 \frac{1}{2}$; horses 2 ; hogs $\frac{3}{1}$ : poultry $\frac{1}{3}$.... Eggs laid $27 \ldots$. Set aside for home use: $1 \frac{1}{2}$ gallons milk. 1 quart cream, 23 eggs.

*Charge Farm Expense with real estate taxes.

He that lives upon hope shall die fasting.-Franklin. 
Weight of feeds fed to live stock to-day: Cattle-Corn fodder $180 \mathrm{lbs}$., hay $180 \mathrm{lbs}$, ground feed 24 lbs., oats $8 \mathrm{lbs}$., skim milk 50 lbs.; horses-Hay 100 lbs., oats 41 lbs.; hogs -Corn on cob 16 lbs., barley 4 lbs., oats 3 lbs., and all skim milk and buttermilk not otherwise used; poultry-Oats 5 los.

The weight of milk given by each cow, morning and evening, to-day was as follows: Nell, morning $6.9 \mathrm{lbs}$, evening 6.6 lbs.; Crossy, morning 8.8 lbs., evening 8.9. lbs.; Black and White Cow, morning 6.5 lbs., evening 6.3 lbs.; Durham, morning 5.4 lbs., evening $5 \mathrm{lbs}$; Dot, morning $11.6 \mathrm{lbs}$, evening $11.5 \mathrm{lbs}$; Holstein, morning $16.2 \mathrm{lbs}$, evening $15.9 \mathrm{lbs}$.

Samples of each cow's milk were taken at both milkings to-day for composite test.

May 16. - Paid for hat $\$ 1.60$; watch repairs $40 \mathrm{c} . .$. Hours of labor: Cattle $4 \frac{1}{2}$; horses 2 ; hogs $\frac{3}{4}$; poultry $\frac{1}{3}$; marking corn land 1 man and team 7 ; hauling manure to garden 1 man and team 7 ; churning 1 woman $1 \frac{1}{2} \ldots$ Eggs laid 27 .... Set aside for home use : $1 \frac{1}{2}$ gallons milk, 1 quart cream, 23 eggs.

May 17.-Hours of labor: Cattle $4 \frac{1}{2}$; horses 2 ; hogs $\frac{3}{4}$; poultry $\frac{1}{3}$; planting corn 2 men 7 ....Eggs laid $22 \ldots$... Set aside for home use: $1 \frac{1}{4}$ gallons milk, 5 eggs.

May 18.-Gave Ed Hibbard for personal expense 50c... Sold 2 lbs. butter at $22 \frac{1}{2} \mathrm{c}$... . Received from Mrs. Sherpy on account, 55c....Hours of labor: Cattle $4 \frac{1}{2}$; horses 2 ; hogs $\frac{3}{4}$; poultry $\frac{1}{3}$; planting corn 2 men 1 ; gardening 1 man $\frac{1}{2}$; killing gophers 1 man 1 ; cutting wood 2 men 1 ; churning 1 woman $1 \frac{1}{2} \ldots$ Eggs laid $19 \ldots$. Set aside for home use: $1 \frac{1}{2}$ gallons milk, 1 quart cream, 6 pounds butter... . Set under hen 13 eggs.

May 19.-Paid for dress goods $\$ 3 . .$. Bought of Mercantile Co. on account, crackers, oranges and pine apples $68 \mathrm{c}$ .... Sold Mercantile Co. on account, 5 lbs. butter $\$ 1.15 \ldots$ Hours of labor: Cattle $4 \frac{1}{2}$; horses 2 ; hogs $\frac{3}{4}$; poultry $\frac{1}{3}$; plowing on corn land 1 man and three horses 6 ; sacking oats

Live within your harvest.-Persian. 
for market 4 men 1 ; breaking corn stalks on corn field 1 man and team 3 ; killing gophers 1 man $\frac{1}{2} \ldots$ Eggs laid 23 .... Set aside for home use: $1 \frac{3}{8}$ gallons milk, 3 pints cream .... Set under hen 13 eggs.

May 20.-Paid for seed corn $\$ 4$; meat 25c; freight on twine 53c.... Bought of Mercantile Co. on account, baking powder and soda $75 \mathrm{c} . .$. Received for boarding horse $\$ 10$ .... Sold 175 lbs. oats at $36 \mathrm{c}$.... Hours of labor: Cattle $4 \frac{1}{2}$; horses 2 ; hogs $\frac{3}{4}$; poultry $\frac{1}{3}$; hauling manure to garden 1 man and team 5, 1 man $2 \frac{1}{2}$; plowing corn land 1 man and 3 horses 2 ; plowing garden 1 man and team 2; marketing oats 1 man and team 4 ; churning 1 woman $1 \frac{1}{2} \ldots$ Eggs laid 34 ....Set aside for home use: $1 \frac{3}{8}$ gallons milk, 1 pint cream.

May 21.-Paid for nails 28c.... Sold $3 \frac{1}{2}$ dozen eggs at 13c....Hours of labor: Cattle $4 \frac{1}{2}$; horses 2 ; hogs $\frac{3}{4}$; poultry $\frac{1}{3}$; plowing on corn field 1 man and 2 horses $4 \frac{1}{2}$; break. ing stalks on corn field 1 man and team 1; cutting wood 2 men 1; "marketing wheat cleaned from succotash and bringing back $100 \mathrm{lbs}$. flour valued at $\$ 2.901$ man and team $4 \ldots$ Eggs laid $18 \ldots$.... Set aside for home use: $1 \frac{5}{5}$ gallons milk, 1 quart cream.... Set under hen 13 eggs.

May 22.-Hours labor: Cattle $4 \frac{1}{2}$; horses 2; hogs $\frac{3}{4}$; poultry $\frac{1}{3} \ldots$ Eggs laid $42 \ldots$... Set aside for home use: $1 \frac{5}{8}$ gallons milk, 1 quart cream, 2 eggs.

May 23.-Paid for poison for killing gophers 25c; postage 10c....Bought of Mercantile Co. on account, cotton cloth $95 \mathrm{c}$; syrup $30 \mathrm{c}$; garden seeds $28 \mathrm{c} . .$. Sold Mercantile Co. on account, 5 lbs. butter at $22 \mathrm{c} . .$. Hours of labor: Cattle $4 \frac{1}{2}$; horses 2 ; hogs $\frac{3}{4}$; poultry $\frac{1}{3}$; plowing on corn land 1 man and team 8 ; dragging corn land 1 man and team 3 : markin: and planting sweet corn 1 man 1; dragging potatoes 1 man and horse $\frac{1}{3}$; cutting and piling wood 1 man $\frac{3}{4} \ldots$ Eggs laid 25 .... Set aside for home use: $1 \frac{3}{3}$ gallons milk. 1 pint cream.

*Charge Food \& Fuel and credit Oats.

A man is one who is faithful to his word.-Turk. 
May 24.-Paid for medicine $\$ 1$; meat $68 \mathrm{c} . .$. Hours of labor: Cattle $4 \frac{1}{2}$; horses 2 ; $\log$ s $\frac{3}{4}$; poultry $\frac{1}{3}$; cleaning harness 1 man $2 \frac{1}{2}$; sacking oats for feed 2 men $\frac{1}{3}$; sprouting potatoes 1 man $\frac{3}{4}$... Eggs laid 25 .... Set aside for home use: $1 \frac{1}{4}$ gallons milk, 1 pint cream, 5 eggs.

May 25.-Hours of labor: Cattle $4 \frac{1}{2}$; horses 2 ; hogs $\frac{3}{4}$; poultry $\frac{1}{3}$; sacking oats for market 2 men 1 ; cleaning succotash 3 men 1; hauling lumber for house 1 man and team 3 ; churning 1 woman $1 \frac{1}{2} \ldots$.. Eggs laid $23 \ldots$... Set aside for home use: $1 \frac{5}{8}$ gallons milk, 1 pint cream, 6 eggs.

Weight of feeds fed to live stock to-day: Cattle-Corn lodder 140 lbs., hay 175 lbs., ground feed 24 lbs., oats 8 lbs., skim milk 50 lbs.; horses-Hay 95 lbs., oats 41 lbs.; hogscorn on cob 16 lbs., barley 3 lbs., oats 2 lbs., and all skim milk and buttermilk not otherwise used; poultry-Oats 5 lbs.

The milk of each cow was weighed to-day, morning and evening, as follows: Nell, morning 6.1 lbs., evening 6 lbs.; Crossy, morning 9 lbs., evening 8.5 lbs.; Black and White Cow, morning 6.1 lbs., evening 5.9 lbs.; Durham, morning 4.7 lbs., evening $4.3 \mathrm{lbs}$; Dot, morning $12 \mathrm{lbs}$., evening 11.7 lbs.; Holstein, morning 16.5 lbs., evening $16.1 \mathrm{lbs}$.

Samples of each cow's milk were taken to-day at both milkings for composite test.

May-26.-Hours of labor: Cattle $3 \frac{1}{2}$; horses $1 \frac{1}{2}$; hogs $\frac{1}{3}$; poultry $\frac{1}{2}$; gardening 1 man $2 \frac{1}{4}$, 1 man and team $\frac{1}{2}$; repairing fence 2 men and team $2 \ldots$ Eggs laid $22 \ldots$ Set aside for home use: $1 \frac{1}{2}$ gallons milk, 2 eggs, $6 \frac{1}{2}$ pounds butter.

The composite samples of each cow's milk taken on the 5 th, 15th and 25th of the month were tested to-day as follows: Nell 3.6; Crossy 3.7; Black and White Cow 4.2; Durham 4.3; Dot 4.2, Holstein 2.8.

A sample of this morning's cream tested 26 per cent.

May 27.-Paid for grinding hog feed 15c; wagon grease $25 \mathrm{c}$; barber $10 \mathrm{c} . .$. Bought of Mercantile Co. on account, berries $25 \mathrm{c}$; 1 barrel of salt $\$ 1.20 \ldots$ Hours of labor: Cat-

A man in the right with God on his side is the majority.-Beecher. 
tle $3 \frac{1}{2}$; horses $1 \frac{1}{2}$; hogs $\frac{1}{3}$; poultry $\frac{1}{2}$; dragging corn land

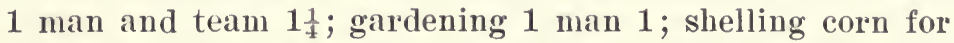
chickens 1 man $\frac{1}{2}$; taking home corn planter 1 man and


woman 2....Eggs laid $34 \ldots$. Set aside for home use: 1 gallon milk, 1 pint cream, 8 eggs.

May 28.-Paid A. O. U. W. life insurance assessment $\$ 2$; hired girl \$3....Bought of Mercantile Co. on account, cloth 14c; lemons 14c; berries 25c.... Sold Mercantile Co. on account, $10 \mathrm{lbs}$. butter at $20 \mathrm{c} .$. . Sold $12 \frac{1}{2}$ dozen eggs at $13 \mathrm{c}$; $2 \frac{1}{4}$ quarts cream at 20c....Hours of labor: Cattle $3 \frac{1}{2}$; horses $1 \frac{1}{2}$; hogs $\frac{1}{3}$; poultry $\frac{1}{2}$; dragging corn land 1 man

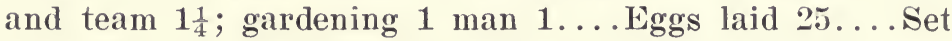
aside for home use: $1 \frac{5}{8}$ gallons milk, 1 pint cream, 11 eggs.

May 29.-Hours of labor: Cattle $3 \frac{1}{2}$; horses $1 \frac{1}{2}$; hogs $\frac{1}{3}$; poultry $\frac{1}{2} \ldots$. Eggs laid $26 \ldots$... Set aside for home use: $1 \frac{3}{3}$ gallons milk, 2 eggs.

May 30.-Hours of labor: Cattle $3 \frac{1}{3}$; horses $1 \frac{1}{2}$; hogs $\frac{1}{3}$; poultry $\frac{1}{2}$; repairing fence 2 men 2 ; marketing hay 2 men $\frac{1}{2}$; painting house 1 man $2 \frac{1}{2} \ldots$ Eggs laid $23 \ldots$. Set aside for home use: $1 \frac{1}{4}$ gallons milk, 1 pint cream.

May 31.-Paid for women's underwear \$4; meat 25c; grinding corn for poultry 10c... Sold 8 lbs. butter at $20 \mathrm{c}$ ....Hours of labor: Cattle $3 \frac{1}{3}$; horses $1 \frac{1}{2}$; hogs $\frac{1}{3}$; poultry $\frac{1}{2}$; repairing fence 3 men $3 \frac{3}{4}$; marketing oats and hauling home lumber 1 man and team 4 ; cutting wood 1 man $1 \frac{1}{4} \ldots$ Eggs laid $30 \ldots$.... Set aside for home use $1 \frac{5}{8}$ gallons milk, 1 quart cream, $6 \frac{1}{4}$ pounds butter.

The rate of wages during the month is $\$ 25$ per month and board. The board is figured at $\$ 2.50$ per week.

The prices of feeds and products used during the month are as follows: Corn fodder $\$ 2$ per ton; hay $\$ 7$ per ton; oats $37 \mathrm{c}$ per bushel; corn 40c per bushel; barley $36 \mathrm{c}$ per bushel; whole milk 85c per hundred; skim milk 12c per hundred; cream 80c per gallon; butter 22c per pound; eggs $13 \mathrm{c}$ per dozen.

"Between right and wrong, never balance a moment."' 
June 1.-Paid for weaving rugs 85c; berries 38c; dressmaking $\$ 3.86 \ldots$ Hours of labor: Cattle $3 \frac{1}{3}$; horses $1 \frac{1}{2}$; hogs $\frac{1}{3}$; poultry $\frac{1}{2} \ldots$...ggs laid $20 \ldots$. Set aside for home use: $\frac{3}{4}$ gallons milk, 1 pint cream, 3 eggs.

June 2.-Hours of labor: Cattle $3 \frac{1}{3}$; horses $1 \frac{1}{2}$; hogs $\frac{1}{3}$; poultry $\frac{1}{2}$; painting house 1 man $4 \frac{1}{2}, 1$ man 3 ; marketing hay 2 men $\frac{1}{2}$; killing weeds along fence 1 man 3 ; repairing buggy-shed 2 men 1 ; churning 1 woman $2 \ldots$ Eggs laid 23 .... Set aside for home use: 1 gallon milk, 24 eggs.

June 3.--Hours of labor: Cattle $3 \frac{1}{2}$; horses $1 \frac{1}{2}$; hogs $\frac{1}{3}$; poultry $\frac{1}{2}$; painting house 1 man 5....Eggs laid $14 \ldots$... Set aside for home use: 1 gallon milk, 1 pint cream.

June 4.-Bought of Mercantile Co. on account, yeast 5c; tea $50 \mathrm{c}$; oranges $30 \mathrm{c}$; 3 boxes berries at $10 \mathrm{c}$; cheese $80 \mathrm{c}$; rubbers $80 \mathrm{c}$; thread $30 \mathrm{c} . .$. Sold Mercantile Co. on account, 15 lbs. butter at $18 \mathrm{c} .$. . Sold $386 \mathrm{bu}$. oats at $36 \mathrm{c} ; \frac{1}{2}$ ton hay $\$ 3$ ....Hours of labor: Cattle $3 \frac{1}{3}$; horses $\frac{1}{2}$; hogs $\frac{1}{3}$; poultry $\frac{1}{2}$; oiling harness 1 man 3 ; churning 1 woman 2... Eggs laid 21 .... Set aside for home use: $1 \frac{3}{8}$ gallons milk, 1 quart cream, 10 eggs, $3 \frac{1}{2}$ pounds butter.

June 5.-Paid for collar and tie 75c; *fire insurance premium $\$ 37.40$; barber $10 \mathrm{c} . .$. Hours of labor: Cattle $3 \frac{1}{2}$; horses $1 \frac{1}{2}$; hogs $\frac{1}{3}$; poultry $\frac{1}{2} \ldots$ Eggs laid $41 \ldots$. . Set aside for home use: $1 \frac{1}{4}$ gallons milk, 1 pint cream, 11 eggs.

Weight of feeds fed to live stock to-day: Cattle-Cows and young stock are in pasture, calves received $25 \mathrm{lbs}$. skim milk; horses-Hay 70 lbs., oats 70 lbs.; hogs—Corn on cob 18 lbs., barley 4 lbs., oats 3 lbs., and all skim milk and buttermilk not otherwise used; poultry-Oats 5 lbs.

The weight of milk given by each cow, morning and evening, was as follows: Nell, morning 7.6 lbs., evening 7.8 lbs.; Crossy, morning 8.8 lbs., evening 8.5 lbs.; Black and White Cow, morning 4 lbs., evening 3.3 lbs.; Durham, morning 5 lbs., evening 4.8 lbs.; Dot, morning 12.9 lbs., evening 13.3

*Charge Farm Expense.

Rust wastes more than use.-French. 
lbs.; Holstein, morning 17.5 lbs., evening 17.8 lbs.; Bangs, morning 9.6 lbs., evening 10 lbs. Bangs' milk has been used from June 1st.

Took sample of each cow's milk at both milkings for composite test.

June 6.-Paid for dress-making $\$ 5$; postage $14 \mathrm{c}$; envelopes 5c; paint for house $\$ 1.45$; horse-shoeing $80 \mathrm{c} . .$. Bought of Mercantile Co. on account, dress goods $\$ 1.55$; rice $25 \mathrm{c}$; pair of rubbers $65 \mathrm{c} . .$. Hours of labor: Cattle $3 \frac{1}{2}$; horses $1 \frac{1}{2}$; hogs $\frac{1}{3}$; poultry $\frac{1}{2}$; oiling harness 1 man 1 ; painting house 1 man 5 ; churning 1 woman $2 \frac{1}{2} \ldots$ Eggs laid $20 \ldots$ Set aside for home use: 1 gallon milk, 1 pint cream.

June 7.-Paid for men's shoes $\$ 2.75 \ldots$ Hours of labor: Cattle $3 \frac{1}{2}$; horses $1 \frac{1}{2}$; hogs $\frac{1}{3}$; poultry $\frac{1}{2}$; marketing oats 1 man and team 4, 2 men 1; dragging corn land 1 man and team $2 \frac{3}{4}$; painting house 1 man $2 \frac{1}{2} \ldots$ Eggs laid $16 \ldots$... Set aside for home use : $1 \frac{1}{3}$ gallons milk, 1 pint cream, 7 pounds dressed chicken.

June 8.-Paid for music lesson $90 \mathrm{c}$; repair on shoes $50 \mathrm{c}$; repair of furniture $75 \mathrm{c}$; oranges $30 \mathrm{c}$; calico $10 \mathrm{c} . .$. Sold Mercantile Co. on account, 5 lbs. butter at $18 \mathrm{c} \ldots$.. Sold 2 lbs. butter at $20 \mathrm{c} . .$. Howrs of labor: Cattle $3 \frac{1}{2}$; horses $1 \frac{1}{2}$; hogs $\frac{1}{3}$; poultry $\frac{1}{2}$; cultivating corn 1 man and team $1 \frac{1}{2}$; cultivating potatoes 1 man and team $\frac{1}{2}$; working road tax 1 man and team 10, 1 man and team $7 \frac{1}{2}$ (Charge Farm Ex-

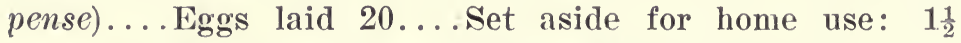
gallons milk, 1 quart cream, 24 eggs, $7 \frac{1}{2}$ pounds butter.

June 9.-Hours of labor: Cattle $3 \frac{1}{2}$; horses $1 \frac{1}{2}$; hogs $\frac{1}{3}$; poultry $\frac{1}{2}$; working road tax 1 man and team 10 ; cultivating corn 1 man and team $7 \frac{1}{2}$; churning 1 woman $2 \ldots$ Eggs laid 32 ....Set aside for home use: $1 \frac{1}{8}$ gallons milk, 1 pint cream, 6 eggs.

June 10.-Paid for curtain rods $38 \mathrm{c} . .$. Bought of Mercantile Co. on account, berries $40 \mathrm{c}$; nutmegs $10 \mathrm{c}$; salmon $60 \mathrm{c}$; vanilla $10 \mathrm{c} . .$. Sold Mercantile Co. on account, $15 \mathrm{lbs}$. butter at $18 \mathrm{c} . .$. Sold $2 \mathrm{lbs}$. butter at 20c; 7 dozen eggs at

Every dog will have his day.-Shakespeare. 
12c....Hour's of labor: Cattle $3 \frac{1}{3}$; horses $1 \frac{1}{2}$; hogs $\frac{1}{3}$; poultry $\frac{1}{2}$; cultivating corn 1 man and team 3 ; gardening 1 man and horse 1, 1 man 2; working road tax 1 man and team $7 \frac{1}{2}$; cultivating potatoes 1 man and horse $1 .$. . Eggs laid $20 \ldots$... Set aside for home use: $1 \frac{3}{8}$ gallons milk, 1 pint cream, 12 eggs.

June 11. - Sold 31 bushels 29 lbs. oats at 38c; 1 calf $\$ 5$ ....Hours of labor: Cattle $3 \frac{1}{3}$; horses $1 \frac{1}{2}$; hogs $\frac{1}{3}$; poultry $\frac{1}{2}$; went to picnic....Eggs laid $22 \ldots$... Set aside for home use: $1 \frac{1}{8}$ gallons milk, 1 quart cream, 5 eggs.

June 12.-Paid A. O. U. W. assessment 50c; meat $\$ 1.18$ ...Bought of Mercantile Co. on account, berries $40 \mathrm{c}$; prunes $50 \mathrm{c} . .$. Hours of labor: Cattle $3 \frac{1}{3}$; horses $1 \frac{1}{2}$; hogs $\frac{1}{3}$; poultry $\frac{1}{2}$; cultivating corn 1 man and team 2 ; working on lawn 1 man and team $\frac{1}{2}$; digging quack grass 1 man 1 ; gardening 1 man $2 \frac{1}{2}$; churning 1 man 2....Eggs laid 33 .... Set aside for home use : $1 \frac{1}{4}$ gallons milk, 3 pints cream, 15 eggs, $4 \frac{1}{2}$ pounds butter.

June 13.-Hours of labor: Cattle $3 \frac{1}{3}$; horses $1 \frac{1}{2}$; hogs $\frac{1}{3}$; poultry $\frac{1}{2} \ldots$ Eggs laid $38 \ldots$.... Set aside for home use: $1 \frac{2}{3}$ gallons milk, 3 pints cream, 10 eggs.

June 14.-Bought of Mercantile Co. on account, lemons $13 \mathrm{c}$; salt $25 \mathrm{c}$; crackers $25 \mathrm{c}$; oranges $30 \mathrm{c}$; cotton cloth $25 \mathrm{c} . .$. Sold Mercantile Co. on account, 5 lbs. butter at $18 c . .$. Hours of labor: Cattle $3 \frac{1}{3}$; horses $1 \frac{1}{2}$; hogs $\frac{1}{3}$; poultry $\frac{1}{2}$; sacking oats for market 2 men $1 \frac{1}{2}$; marketing hay 2 men $\frac{1}{2}$; cultivating corn 1 man and team $3 \frac{3}{4}$; painting house 1 man 3 ....Eggs laid $10 \ldots$ Set aside for home use: $1 \frac{1}{8}$ gallons milk, 2 quarts cream, 6 eggs.

June 15.-Hours of labor: Cattle $3 \frac{1}{2}$; horses $1 \frac{1}{2}$; hogs $\frac{1}{3}$; poultry $\frac{1}{2}$; marketing oats and bringing home two painters 1 man and team $3 \frac{1}{2}$; cultivating corn 1 man and team 3 ; washing buggy 1 man $1 \frac{1}{2}$; painting house 3 men $6 \ldots$ Eggs laid 25 .... Set aside for home use: $1 \frac{5}{8}$ gallons milk, 1 quart cream, 19 eggs, 5 pounds butter.

Saving is a greater art than gaining.-German. 
Weight of feeds fed to live stock to-day: Cattle-Skim milk to calves $25 \mathrm{lbs}$, cows and young stock in pasture; horses-Hay 70 lbs., oats 70 lbs.; hogs-Corn on cob, 18 lbs., barley 3 lbs., oats 2 lbs., and all skim milk and buttermilk not otherwise used; poultry-Oats 5 lbs.

The weight of milk given by each cow, morning and even ing, was as follows: Nell, morning $9.1 \mathrm{lbs}$., evening 8.9 lbs.; Crossy, morning 8.5 lbs., evening, 8.2 lbs.; Black and White Cow, morning 2.7 lbs., evening 2.3 lbs.; Durham, morning 5.2 lbs., evening 5 lbs.; Wot, morning 13.7 lbs, evening 13.6 lbs.; Holstein, morning 18.6 lbs., evening 18.5 lbs.; Bangs, morning 11.9 lbs., evening $11.5 \mathrm{lbs}$.

Took sample of each cow's milk both morning and evening for composite test.

June 16.-Paid for painting materials 50c.... Sold $8 \mathrm{lbs}$. butter at 20c....Hours of labor: Cattle $3 \frac{1}{3}$; horses $1 \frac{1}{2}$; hogs $\frac{1}{3}$; poultry $\frac{1}{2}$; cultivating garden 1 man and horse $\frac{1}{2}$; cultivating corn 1 man and team 8 ; painting house 1 man 6 . 2 men 10 ; churning 1 man $2 \frac{1}{2}, 1$ woman $\frac{1}{2} \ldots$ Eggs laid 10 .... Set aside for home use: $1 \frac{1}{4}$ gallons milk, 1 pint cream, 11 eggs, $5 \frac{1}{2}$ pounds dressed chicken, 3 quarts strawberries.

June 17.-Hours of Jabor: Cattle $3 \frac{1}{2}$; horses $1 \frac{1}{2}$; hogs $\frac{1}{3}$; poultry $\frac{1}{2}$; cultivating corn 1 man and team 7 ; painting house 1 man 7, 2 men 10 ...Eggs laid $24 \ldots$. Set aside for home use: $1 \frac{5}{8}$ gallons milk, 1 pint cream, 8 eggs, 4 pounds butter.

June 18.--Paid for repairs on ice box $40 \mathrm{c}$; wall paper $35 \mathrm{c}$ ... Bought of Mercantile Co. on account, breakfast food 30c .... Sold $12 \frac{1}{2}$ bu. oats at $40 \mathrm{c} ; 2$ lbs. butter at $20 \mathrm{c} \ldots$.. Hours of labor: Cattle $3 \frac{1}{2}$; horses $1 \frac{1}{2}$; hogs $\frac{1}{3}$; poultry $\frac{1}{2} . .$. Eggs laid $26 \ldots$. . Set aside for home use: $1 \frac{5}{8}$ gallons milk, 12 eggs.

June 19.-Hours of labor: Cattle $3 \frac{1}{2}$; horses $1 \frac{1}{2}$; hogs $\frac{1}{3}$; poultry $\frac{1}{2}$; repairing house 1 man 4 ; paper hanging 1 man 10 ; churning 1 man $1 \frac{1}{2}, 1$ woman $2 \frac{1}{2} \ldots$ Eggs laid $20 \ldots$. Set aside for home use: $1 \frac{1}{4}$ gallons milk, 2 quarts cream, 4 eggs.

When the well is dry, we know the worth of water.-Franklin. 
June 20.-Paid for soap 10c; cream of tartar 25c... Hours of labor: Cattle $3 \frac{1}{4}$; horses $1 \frac{1}{2}$; hogs $\frac{1}{3}$; poultry $\frac{1}{2}$; cultivating corn 1 man and team $3 \frac{1}{2}$; cultivating potatoes 2 men and 1 horse 1 ; painting house 1 man $2 \frac{1}{2}, 1$ man 7 ; churning 1 woman $2 \frac{1}{2}$... Eggs laid 17 .... Set aside for home use: $1 \frac{5}{8}$ gallons milk, 3 pints cream, 5 eggs.

June 21.-Bought of Mercantile Co. on account, 1 dozen oranges $30 \mathrm{c} . .$. Sold Mercantile Co. on account, 5 lbs. butter at $18 \mathrm{c} . .$. Hours of labor: Cattle $3 \frac{1}{2}$; horses $1 \frac{1}{2}$; hogs $\frac{1}{3}$; poultry $\frac{1}{2}$; cultivating corn 1 man and team $3 \frac{1}{2}$; cultivating garden 1 man and team $\frac{1}{3}$; painting house 1 man $4 \frac{1}{2}, 2$ men $10 \ldots$ Eggs laid $10 \ldots$. Set aside for home use: $1 \frac{1}{2}$ gallons milk, $2 \frac{1}{2}$ quarts cream, 1 egg.

June 22.-Paid for labor, painting and papering house $\$ 26$; barber $10 \mathrm{c} . .$. Sold 115 lbs. oats at $37 \mathrm{c}$; 5 lbs. butter at $18 \mathrm{c} ; 2$ lbs. butter at $20 \mathrm{c} ; 2$ dozen eggs at $15 \mathrm{c} . .$. Received for boarding horse $\$ 1$... Hours of labor: Cattle $3 \frac{1}{2}$; horses $1 \frac{1}{2}$; hogs $\frac{1}{3}$; poultry $\frac{1}{2}$; painting house 1 man $4 \frac{1}{2}$; taking painters to town, 1 man and team 3 ; gardening 1 man $3 \frac{1}{4}$; churning 1 woman $2 \ldots$ Eggs laid $19 \ldots$. . Set aside for home use: $\frac{3}{4}$ gallon milk, 1 quart cream, 16 eggs, $8 \frac{1}{2}$ pounds dressed chicken.

June 23.-Hours of labor: Cattle $3 \frac{1}{2}$; horses $1 \frac{1}{2}$; hogs $\frac{1}{3}$; poultry $\frac{1}{2}$; gardening 1 man $1 \frac{1}{2} \ldots$ Eggs laid $19 \ldots$. . Set aside for home use: $1 \frac{1}{2}$ gallons milk, 1 pint cream, 12 eggs, 5 pounds butter, 11 quarts strawberries.

June 24.-Hours of labor: Cattle $3 \frac{1}{2}$; horses $1 \frac{1}{2}$; $\operatorname{hogs} \frac{1}{3}$; poultry $\frac{1}{2}$; cleaning succotash 2 men 2 ; gardening 2 men 1 ; churning 1 man $1 \frac{1}{2}, 1$ woman $\frac{1}{2} \ldots$ Eggs laid $19 \ldots$. Set aside for home use: 1 gallon milk, 2 pints cream, 5 eggs, 5 quarts strawberries.

June 25.-Paid bill for paint, oil and brushes used in house painting $\$ 27.65$; wall paper $\$ 4.85$; medicine $35 \mathrm{c} . .$. A. O. U. W. life insurance assessment $\$ 1$; meat $30 \mathrm{c}$; harness repairs $6 \mathrm{c} . .$. Bought of Mercantile Co. on account, stone jar 10c; matches 20c; salmon $\$ 1.20$; bird-seed $5 c$; 7 yards

An honest man is the noblest work of God.-Pope. 
calico at $7 \mathrm{c} . .$. Sold $6 \mathrm{lbs}$. butter at $20 \mathrm{c} ; 1 \frac{1}{2}$ quarts cream at 20c....Hours of labor: Cattle $3 \frac{1}{2}$; horses $1 \frac{1}{2}$; $\operatorname{logs} \frac{1}{3}$; poultry $\frac{1}{2}$; cleaning hay mows 1 man 2 ; repairing house 1 man 1; hoeing strawberries 1 man 5 ; churning 1 man $1 \frac{1}{2}$, 1 woman $\frac{3}{4} \ldots$ Eggs laid $12 \ldots$. . Set aside for home use: $1 \frac{3}{8}$ gallons milk, 3 pints cream, 10 eggs, 7 quarts strawberries.

Weight of feeds fed to live stock to-day: Cattle-Skim milk to calves $25 \mathrm{lbs}$, cows and young stock in pasture; horses-Hay 70 lbs., oats 70 lbs.; hogs-Corn on cob 18 lbs., barley 4 lbs., oats 3 lbs., and all skim milk and buttermilk not otherwise used; poultry-Oats 5 lbs.

Each cow's milk was weighed both morning and evening to-day, with the following results: Nell, morning 9.6 lbs., evening 9.5 lbs.; Crossy, morning 8 lbs., evening 7.8 lbs.; Black and White Cow, morning 1.4 lbs., evening $1.3 \mathrm{lbs}$; Durham, morning 5.5 lbs., evening 5.4 lbs.; Dot, morning 14.2 lbs., evening 13.9 lbs.; Holstein, morning 19 lbs., evening $19.3 \mathrm{lbs}$; Bangs, morning $12 \mathrm{lbs}$, evening $11.9 \mathrm{lbs}$.

Took sample of each cow's milk at both milkings for composite test.

June 26.-Hours of labor: Cattle $3 \frac{1}{2}$; horses $1 \frac{1}{2}$; hogs $\frac{1}{3}$; poultry $\frac{1}{2} \ldots$ Eggs laid $31 \ldots$. Set aside for home use: 1 gallon milk, 1 quart cream, 12 quarts strawberries.

The composite samples of milk from each cow taken on the 5th, 15th and 25th of the month, and a sample of this morning's cream, were tested to-day, showing per cent of butter fat as follows: Nell 3.4; Crossy 3.9; Black and White Cow 4.3; Durham 4.2; Dot 4.2; Holstein 3.2; Baıgs 3.7. Cream 27.

June 27.-Paid for underweár and dry goods $\$ 10 \ldots$ Bought of Mercantile Co. on account, dry goods $\$ 1.09 \ldots$ Sold $1 \frac{3}{4}$ lbs. butter at $20 \mathrm{c} . .$. Hours of labor: Cattle $3 \frac{1}{2}$; horses $1 \frac{1}{2}$; hogs $\frac{1}{3}$; poultry $\frac{1}{2}$; cultivating corn 1 man and team $7 \frac{1}{2}$; hoeing potatoes 1 man $7 \ldots$ Eggs laid $16 \ldots$.... Set

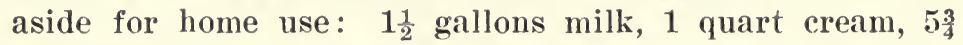
pounds butter, 4 quarts strawberries. 
June 28.-Hours of labor: Cattle $3 \frac{1}{2}$; horses $1 \frac{1}{2}$; hogs $\frac{1}{3}$; poultry $\frac{1}{2}$; cultivating corn 1 man and team $7 \frac{1}{2}$; hoeing potatoes 1 man $\frac{3}{4}$; gardening 1 man $6 \frac{1}{2}$; picking strawberries 1 man $\frac{1}{2}$; churning 1 man 2,1 woman $\frac{1}{2} \ldots$. Eggs laid $17 \ldots$ Set aside for home use: $\frac{5}{8}$ gallons milk, 1 quart cream, 6 eggs, 9 quarts strawberries.

June 29.-Hours of labor: Cattle $3 \frac{1}{2}$; horses $1 \frac{1}{2}$; hogs $\frac{1}{3}$; poultry $\frac{1}{2}$; gardening 2 men and 1 horse 2 ; pulling weeds along fence 2 men $\frac{1}{2}$; poisoning potato bugs 1 man $2 \frac{1}{2}$; sacking oats for market 2 men $\frac{3}{4}$; cultivating corn 1 man and team 8... Eggs laid 18... Set aside for home use: $\frac{5}{8}$ gallons milk, 1 quart cream, 11 eggs, $2 \frac{1}{2}$ pounds butter, 27 quarts strawberries.

June 30.-Paid for repair of furnace $\$ 4$; repairs of mower $20 \mathrm{c}$; barber $10 \mathrm{c}$; hay fork and whetstone $50 \mathrm{c} . .$. Sold $3 \mathrm{lbs}$. butter at $20 \mathrm{c} ; 12$ dozen eggs at $12 \mathrm{c}$; exchanged $18 \mathrm{bu}$. wheat at $84 \mathrm{c}$ for $550 \mathrm{lbs}$. flour (This wheat cleaned from succotash) ....Hours of labor: Cattle $3 \frac{1}{2}$; horses $1 \frac{1}{2}$; hogs $\frac{1}{3}$; poultry $\frac{1}{2}$; marketing oats 1 man and team 5; picking strawberries 1 man $\frac{3}{4}$; churning 1 man $1 \frac{1}{2}, 1$ woman $1 \frac{1}{2} \ldots$ Eggs laid 19 .... Set aside for home use: $1 \frac{3}{8}$ gallons milk, 16 eggs, 5 quarts strawberries.

The rate of wages during the month is $\$ 25$ per month and board. The board is figured at $\$ 2.50$ per week.

The prices of feeds and products used during the month are as follows: Hay $\$ 7$ per ton; oats $36 \mathrm{c}$ per bushel; corn 40c per bushel; barley 37c per bushel; whole milk 80c per hundred; skim milk 11e per hundred; cream 70c per gallon; butter 20c per pound; eggs 13c per dozen; dressed chicken 9c per pound.

Note.-No inventory is given at the end of June because the value of growing crops would be largely an assumption. If it is thought best to close the accounts the students may be required to make an assumed inventory throughout.

The tree that does not bend is broken.-Machetanz. 


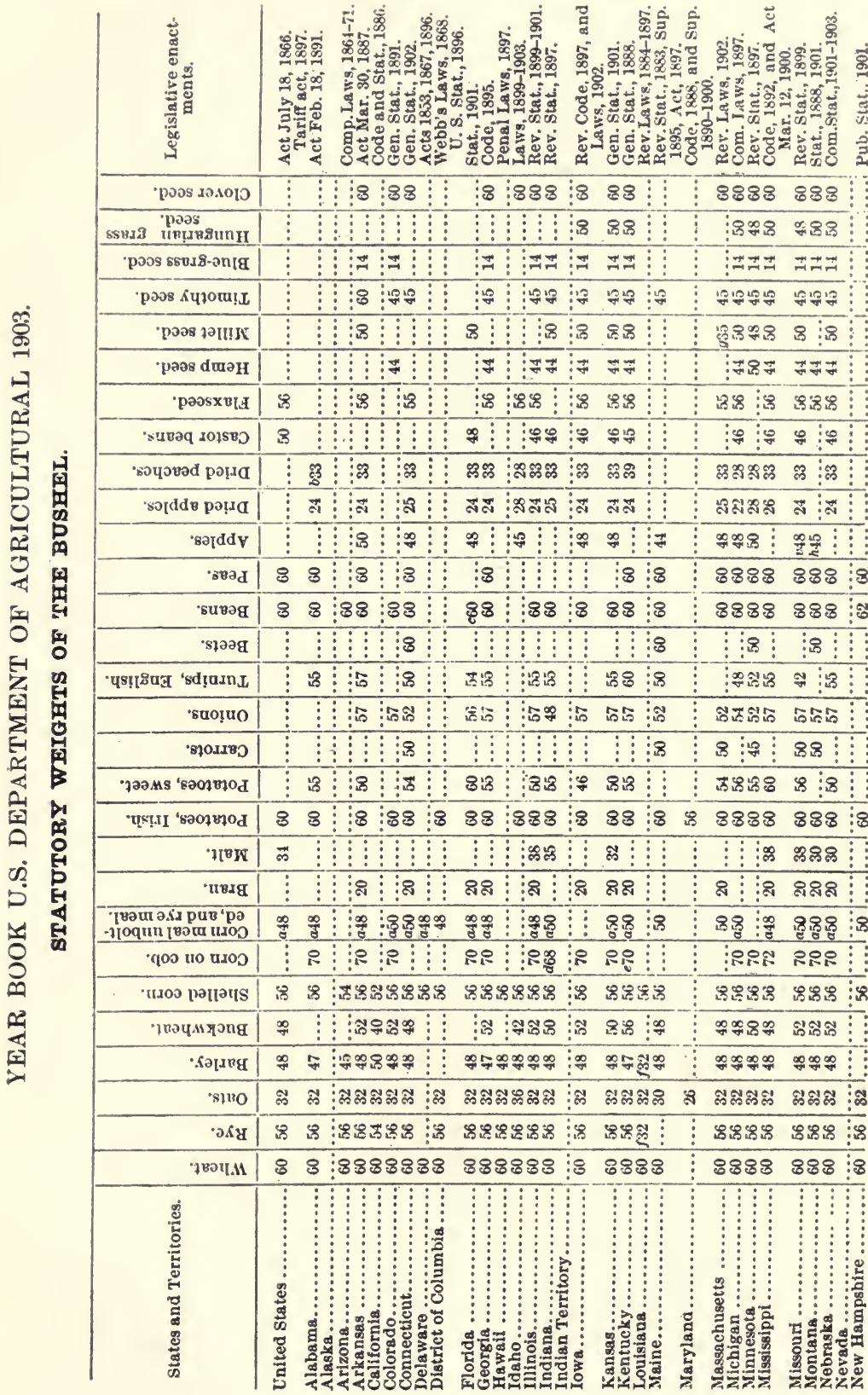




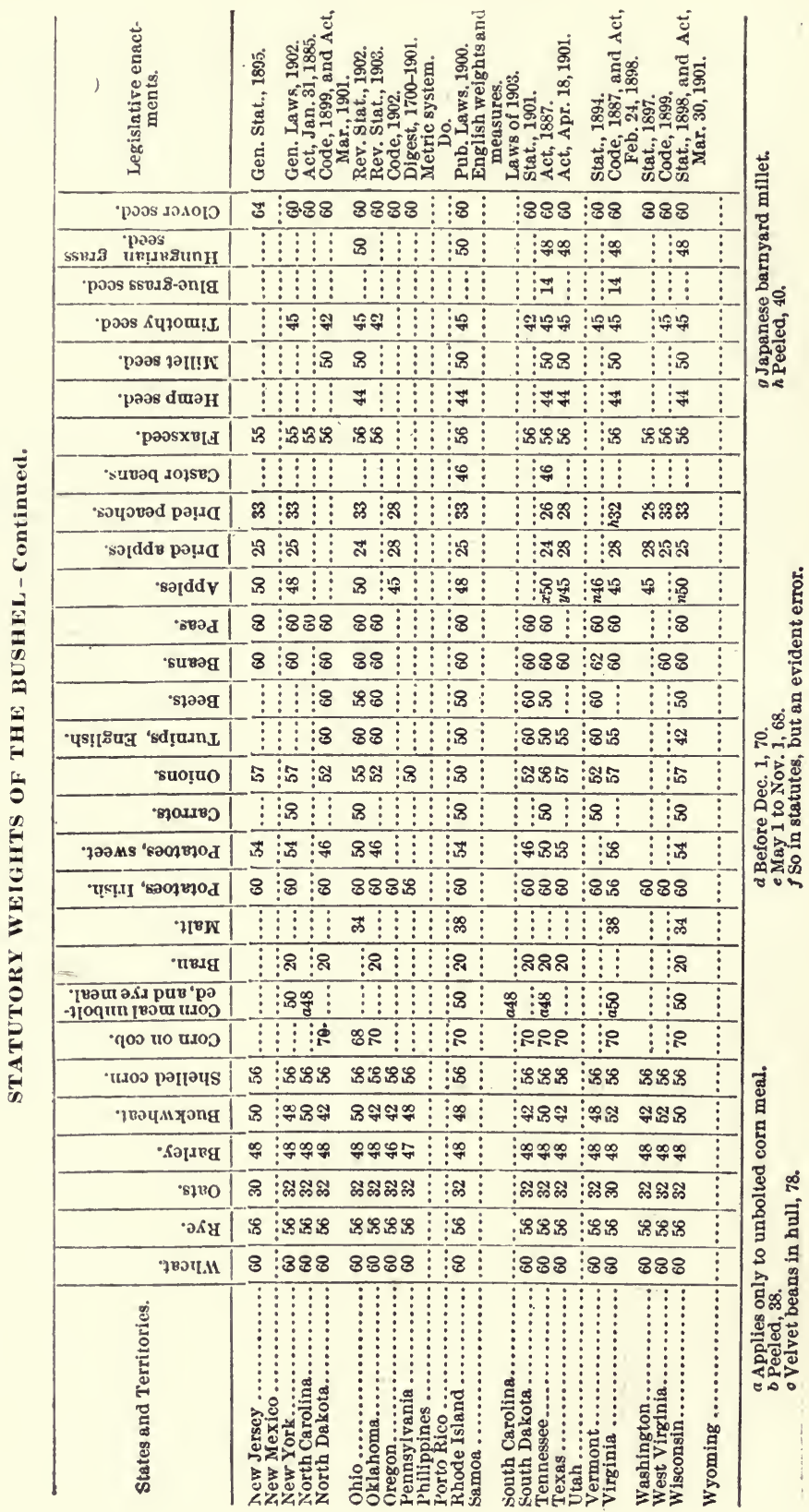




\section{CHAPTER XI.}

\section{MATERIALS USED IN FARM ACCOUNTS.}

Everyone desiring to keep a set of accounts either on the farm, in the home, or private business, will find the card system as herein illustrated, simple, adequate, and adaptable to every requirement. No one should allow his affairs to go on month after month without knowing their true condition. If each housewife kept a true record of her income and outlay it would put her in possession of facts so valuable that her ability as a producer would be increased tenfold. To know, is to succeed; to doubt, is to fail.

After having learned how to keep accounts, it is quite as important to have the proper utensils, materials, and the like. First of all there should be some place, a room, a desk, a table, or a box where the bookkeeping material could be kept perfectly safe; a place where it may always be kept so that it can be found when wanted. A place for everything and everything in its place, should be our motto; not a place for everything and everything out of its place. Many men and women too, have become distracted over the petty annoyances of having to hunt for pencil and paper every time any writing had to be done. And it is no wonder that so few know the real value of records. A lack of system has been the strongest deterrent. Have a desk if you possibly can; one that closes, so that thoughtless children or other intruders may be kept out. In this desk have writing paper, pencils, erasers, pen and ink, and any other office necessities. These silent forces will ever be ready to serve you and bring much joy to the entire household.

For the purpose of this method of bookkeeping, you will need a set of cards containing enough to last a year. Have a box large enough to contain these cards. Such a box may 
be made of pasteboard but wood is preferable. The cut below gives a good idea of one.

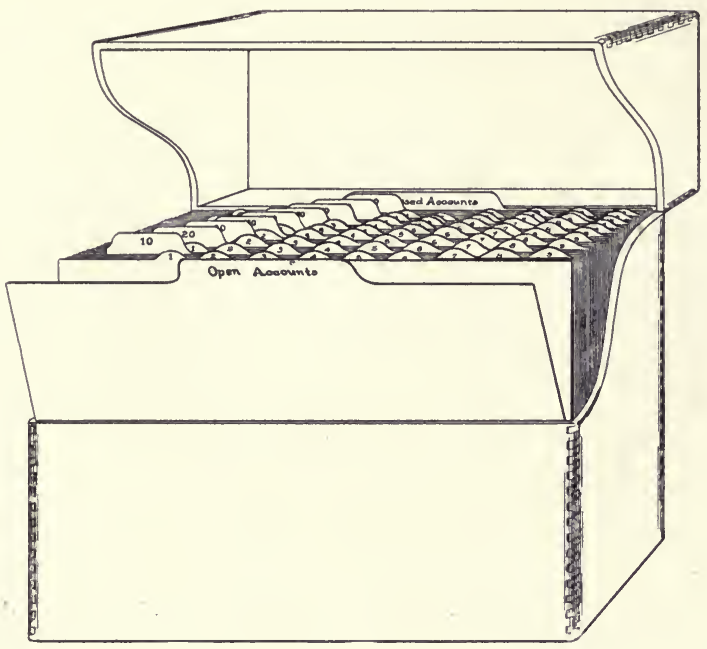

This box is $8 \frac{7}{8}$ inches long, $6 \frac{1}{2}$ inches high and 3 inches deep. It is just the size to hold $5 \times 8$ cards. It is made of oak, well hinged and has a strong lock and key. Anyone handy with tools could make a similar box. For those desiring a box as perfect as the best workmanship can make it, arrangements are being made to supply it as well as the cards. While the ruled stock auxiliary cards are such as our experience has demanded, it should be borne in mind that you may take blank cards and rule such as you desire or you may have them ruled by a printer at a slight additional cost. Pedigrees and other records may be made on the cards of the regular size and kept in the cabinet.

Some prefer long drawers instead of a short box. Below

Art is the beautiful way of doing things.-Hubbard. 
two cuts are given. The first one contains one drawer and the second a two drawer cabinet.
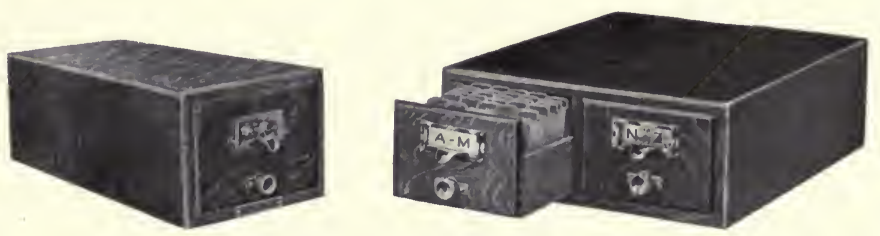

There are an infinite number of these cabinet devices ready made, which may be purchased at reasonable prices.

\section{CLIPPINGS AND OTHER USEFUL INFORMATION.}

It is a good plan to clip from the papers valuable articles pertaining to subjects you are especially interested in. This is much preferable to lumbering up your house and desk with stacks of printed matter, the larger portion of which you do not care for. Many attempt to keep volumes of papers and in some instances bind them because they contain some valuable articles. It often happens that the articles can't be found when wanted since they are buried in a mass of literature. Binding volumes of papers is more the function of libraries than of individuals. It is questionable whether there are in the homes of the average individual, papers worth binding. But there is found in almost every publication something worth keeping. It should be clipped out and preserved. A common letter file is a good thing in which to file away these clippings, alphabetically under the subject matter, or by using envelopes with the subject matter written thereon. These may be arranged alphabetically and placed in a tray or box as is recommended for the ledger cards. No thoughtful person should fail to clip from his periodicals.

Counsel after action is like rain after harvest.-Dan. 
Standard magazines should be kept intact and filed away on a shelf arranged according to date of publication. Each volume is indexed so that easy reference may be made to every subject discussed. Such an array of facts as will soon accumulate under a systematic selection of this kind will be a priceless treasure and an available force of no small magnitude. 


\section{STATUTES OF MINNESOTA GOVERNING WEIGHTS AND MEASURES TAKEN FROM THE REVISED CODE, 1906.}

The State Treasurer shall keep weights, measures, and scales which shall conform to the standards established by law, and shall test thereby all weights, measures, and scales presented to him by any county sealer, and, when he finds them accurate, shall stamp upon them, with a seal kept for that purpose, the letters "Min."

Every county treasurer shall be the sealer of weights and measures for his county. He shall keep a full set of weights, measures, and scales, and in January, 1910, and in every fifth January thereafter, and whenever new ones are procured, shall test thereby all weights, measures, and scales presented to him, and, when he finds them accurate, shall stamp upon them, with a seal kept for that purpose, the letters "Min." He shall receive five cents for every weight, measure, or scale tested. He may appoint deputy sealers, whose appointment shall be filed with the register of deeds.

\section{Dry Measure.}

The standard measure of capacity for commodities sold by dry measure shall be the bushel containing 2,150.4 cubic inches. The half bushel, peck, half peck, quarter peck, quart and pint shall be derived by successively dividing that measure by two.

\section{Liquid Measure.}

The standard measure of capacity for liquids, except beer and milk, shall be the wine gallon, containing 231 cubic inches and 31.50 gallons shall constitute a barrel, and 63 gallons a hogshead. The standard measure of capacity for beer and milk shall be the gallon containing 282 eubic inches.

\section{Lineal Measure.}

The standard measure of length, from which all other measures of extension, lineal, superficial, or solid, shall be derived, is the yard, of 3 feet, or 36 inches.

\section{Hundred Weight.}

In contracts for the sale of goods or commodities, unless a contrary intention appears, the term "hundred weight" shall mean one hundred pounds avoirdupois. 


\section{Standard Weight of Bushel.}

In contracts for the sale of any of the following articles, unless a coutrary intention appears, the term "bushel", shall mean the number of pounds avoirdupois herein stated:

Corn in ear, 70 ; beans, peas, wheat, clover seerl, and Irish potatoes, 60 ; broom corn seed and sorghum seed, 57; shelled corn and rye, 56 ; sweet potatoes, 55; onions and rutabagas, 52; buckwheat, hemp seed, ripe seed, beets and green apples, 50; barley, millet, and Hungarian grass seed, 48; earrots and timothy seed, 45; blueberries and parsnips, 42; currants and gooseberries, 40; cranberries, 36; cats, 32; dried apples and dried peaches, 28; charcoal, 20; bluegrass, crehard grass, and red top seed, 14; plastering hair, unwashed, 8; plastering hair, washed, 4; coal, 80 , but if sold by the ton the weight shall be 2000 pounds; lime, 80 , but if sold by the barrel the weight shall be 200 pounds; and a cord of wood shall mean 128 cubic feet.

Whoever, in buying, shall take any greater number of pounds or cubic feet to the bushel, ton, or cord, as the case may be, than is herein allowed, or in selling shall give any less number, unless the contract so provides, shall be guilty of a misdemeanor.

\section{Sealing Required.}

Every person engaged in any business requiring the use of weights or measures shall cause those used by him to be tested and sealed by the county sealer. Every person who shall buy, sell, or dispose of any goods or commodities by an unsealed weight, measure, or scale which has been sealed, but is incorrect, shall be guilty of a misdemeanor; but no contract of sale shall thereby be rendered void.

\section{Testing upon Request.}

Upon written request of any person aggrieved, and payment of one dollar, and mileage at the rate of 20c. per mile going and returning, the county sealer, or his deputy shall test any weights: measures, or scales used in this county, whether already sealed or not. If such dealer or deputy shall give to the person complained of prior notice of such testing, he shall be guilty of a misdemeanor.

\section{Neglect to Procure Standards.}

Whenever a county treasurer is requested in writing to procure any standard of weight or measure required by law to be kept by him, he shall procure the same within 20 days thereafter, or forfeit to the county $\$ 100.00$ at the suit of any interested person. 
FORM OF PEDIGREE.

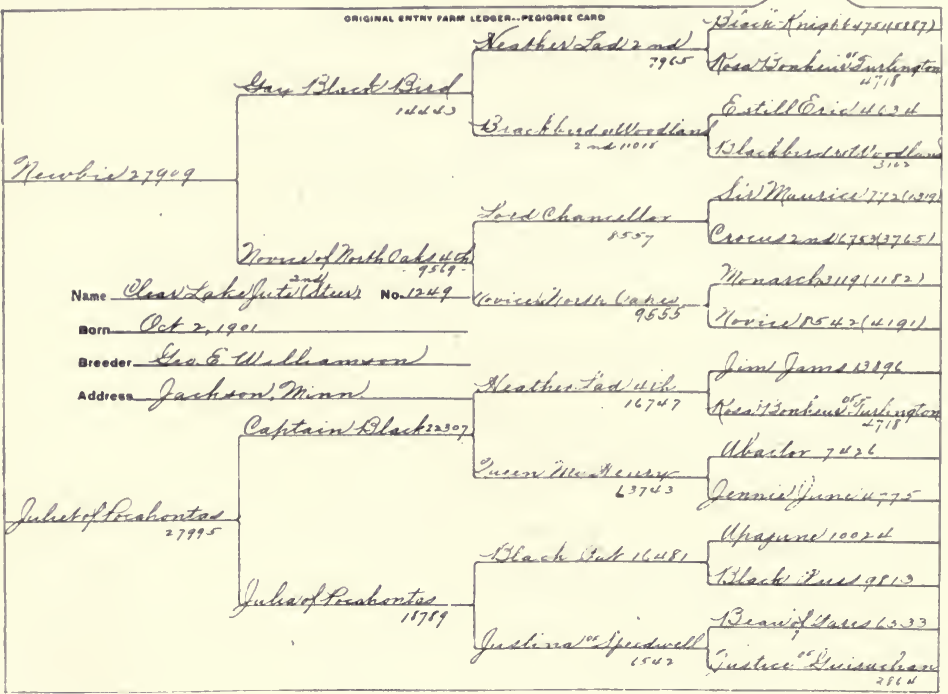

FORM OF NOTE.

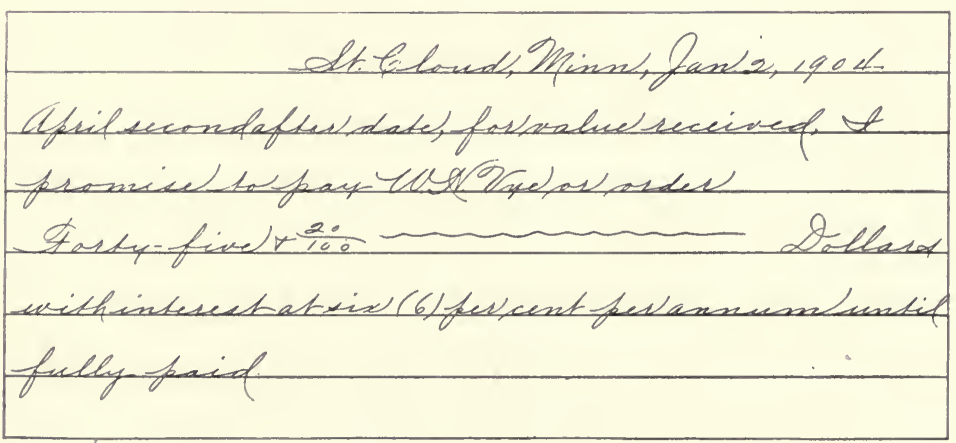

Beware of little expenses; a small leak will sink a ship.-Franklin. 


\section{ANSWERS TO PRELIMINARY WORK}

\section{Vye's Farm Accounts.}

Student.

Oct. Balance

Nov.

Dec.

Jan.

Feb.

Mar.

John Calendar, Due him ..

Edw. Berry, Due him

William Connelly, Due him

Ralph Palmer, Due him.

Hogs, Gain

Sheep, Gain

Cattle, Gain

Hogs, Loss
No. I. No. II. No. III. $\$ 18.78$

45.56

9.09

7.53

15.88

9.28

$\$ 19.02$

19.16

2.86

2.64

.21

5.18

$\$ 21.42$

1.84

4.39

13.05

17.57

11.84

$\$ 1.05$

34.49

8.95

96.12

21.63

83.18

$13.18 \$ 66$

70.35 






WILL BE ASSAL FINE

THIS BOOK ONSED FOR FAILURE CENTS DAY INCREASE THE DATE DUE. THE RETURN OVERDUE TO \$1.00 ONNTS ON THE PENALTY
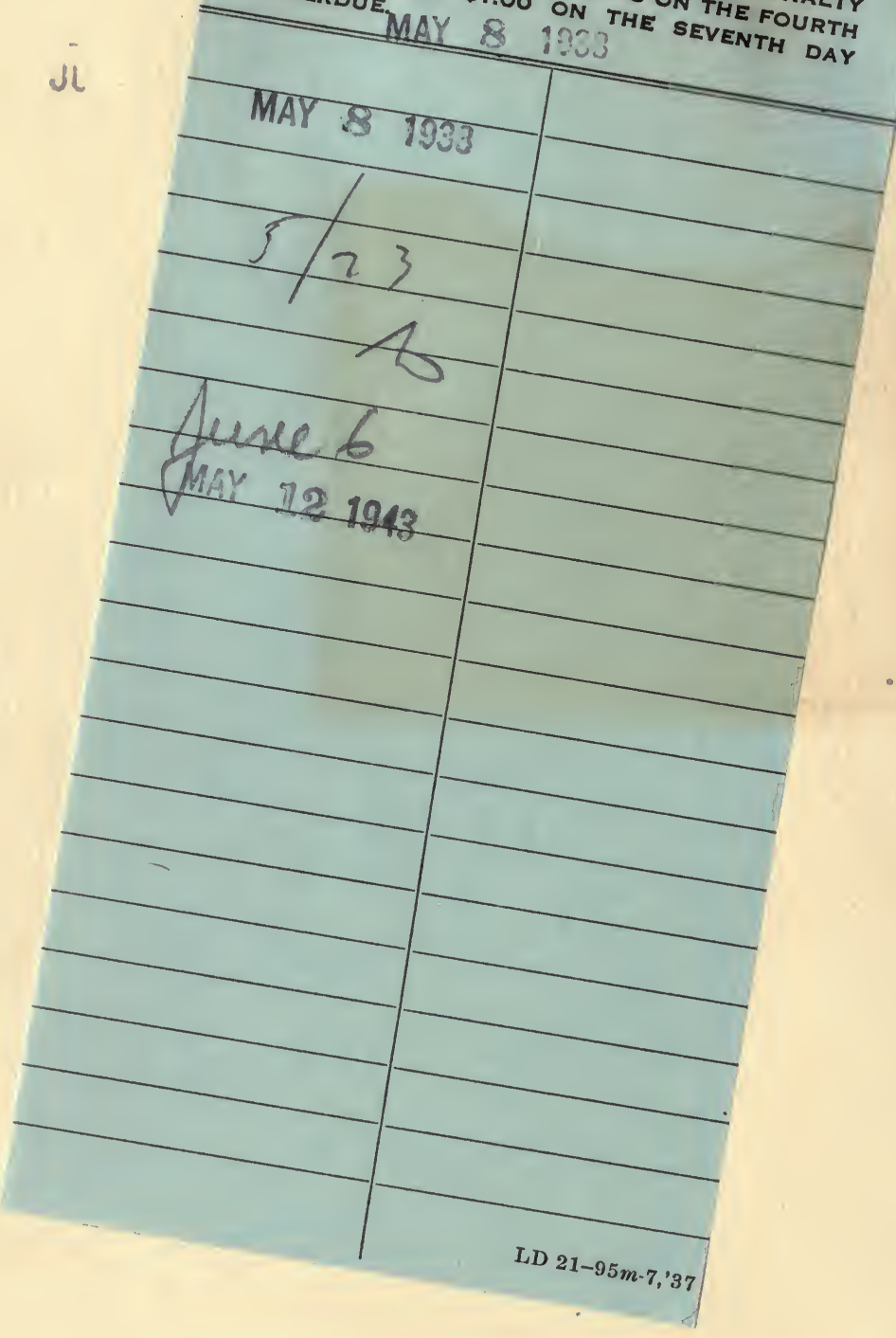


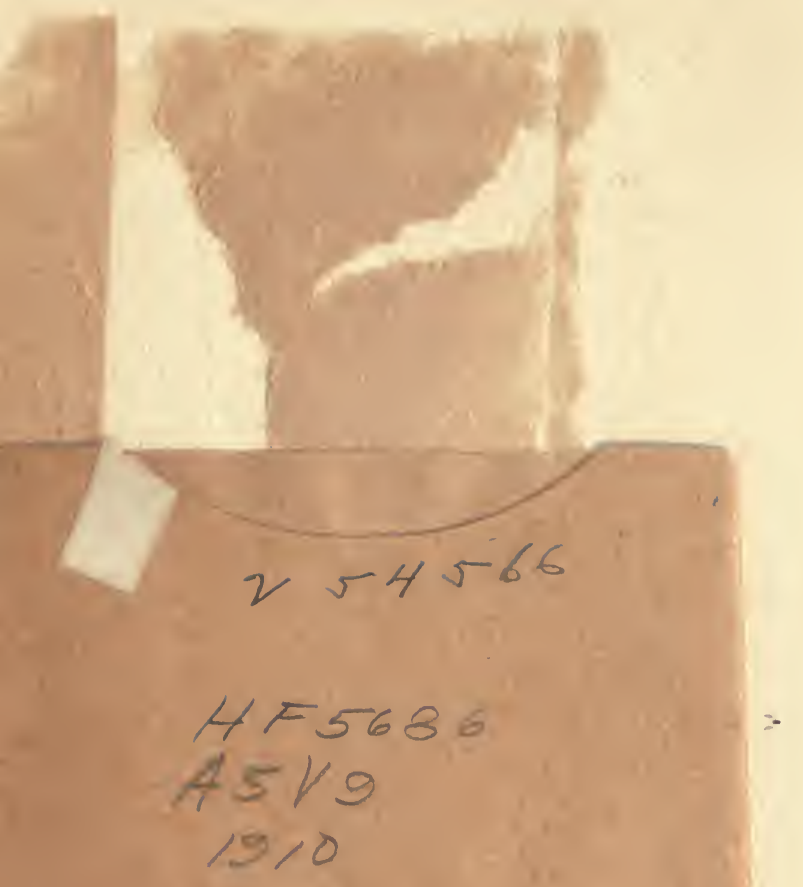

UNIVERSITY OF CALIFORNIA LIBRARY 


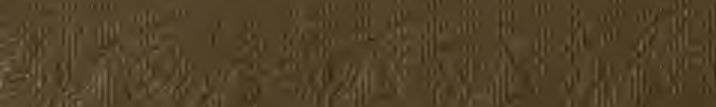

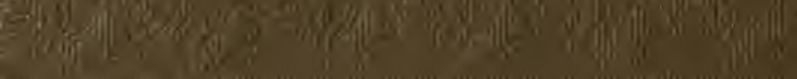

The

(1)

19010 